\title{
CLIMATE CHANGE AND FOREST MANAGEMENT AFFECT FOREST FIRE RISK IN FENNOSCANDIA
}




\title{
RAPORTTEJA \\ RAPPORTER \\ REPORTS
}

No. 2021:3

\section{CLIMATE CHANGE AND FOREST MANAGEMENT AFFECT FOREST FIRE RISK IN FENNOSCANDIA}

\author{
Juha Aalto, Ari Venäläinen (eds.) \\ Tuula Aalto, Leif Backman, Joonas Kolstela, Ilari Lehtonen, Tero Partanen, Laura Thölix, Timo \\ Virtanen (Finnish Meteorological Institute) \\ Ekaterina Shorohova, Ilkka Vanha-Majamaa (Natural Resources Institute Finland) \\ Päivi Mäkelä, Jarno Ruusunen (Emergency Service Academy Finland) \\ Henrik Lindberg (Häme University of Applied Sciences) \\ Mikael Kukkonen (Lapland University of Applied Sciences) \\ Rami Ruuska (Ministry of the Interior Finland) \\ Jan Wahlberg (Ministry for Foreign Affairs of Finland) \\ Anders Granström (Swedish University of Agricultural Sciences) \\ Andrey Gromtsev, Maria Levina (Karelian Research Center of the Russian Academy of Sciences)
}

Ilmatieteen laitos

Meteorologiska institutet

Finnish Meteorological Institute

Helsinki 2021 
ISBN 978-952-336-134-8 (nide)

ISBN 978-952-336-135-5 (pdf)

ISSN 0782-6079

Edita Prima Oy

Helsinki, 2021 
Nimeke: Ilmastonmuutos ja metsänhoito vaikuttavat metsäpaloriskiin Fennoskandiassa

Metsä- ja maastopalot ovat luonnollinen osa monia ekosysteemejä. Kuitenkin erityisesti suuret palot saattavat aiheuttaa laajaa yhteiskunnallista, taloudellista sekä ekologista tuhoa. Metsäpalot ovat yksi keskeinen kasvihuonekaasujen sekä mustan hiilen lähde, joiden lisääntyvät pitoisuudet ilmakehässä kiihdyttävät ilmastonmuutoksen etenemistä. Ruotsin viimeaikaiset suuret metsäpalot osoittavat, että metsäpaloihin on kiinnitettävä huomiota myös muualla Fennoskandiassa. Tässä hankkeen ”Metsäpalot Fennoskandian alueella ilmaston ja metsien rakenteen muuttuessa" loppuraportissa vedetään yhteen tämänhetkinen tieto metsäpalojen esiintymisestä, havainnoinnista, mallintamisesta sekä hillinnästä Fennoskandiassa. Raportissa käsitellään myös metsäpalojen merkitystä mustan hiilen lähteenä Arktisella alueella, sekä kansainvälisen yhteistyön tärkeyttä metsäpaloihin liittyvissä asioissa.

Raportissa esitellään metsäpalojen syttymiseen, leviämiseen ja voimakkuuteen vaikuttavia tekijöitä erityisesti Fennoskandian olosuhteiden näkökulmasta. Raportti korostaa tämän alueen ilmaston luontaisesti suurta vaihtelua, joka heijastuu edelleen metsäpaloriskiin. Suurin osa metsäpaloista on ihmisten aiheuttamia, johtuen esimerkiksi tulen huolimattomasta käsittelystä sekä metsänhakkuista. Sään ja ilmaston lisäksi myös metsän ominaispiirteet vaikuttavat palojen syttymiseen, voimakkuuteen sekä leviämiseen. Raportissa esitetään ajallisesti kattavat palotilastot Suomen, Ruotsin ja Karjalan tasavallan osalta. Tilastot osoittavat, että viimeisten 150 vuoden aikana vuotuiset paloalat ovat vähentyneet selvästi Fennoskandiassa. Pois lukien Ruotsin suuret metsäpalot 2014 ja 2018, viimeisten 25 vuoden aikana paloalat ovat pysyneet alhaisina tehokkaan palontorjunnan ja metsänhoidon ansiosta.

Ilmastonmuutoksen ja metsänhoidon vaikutuksia metsäpaloihin tulevaisuudessa tarkasteltiin maanpintamallien avulla. Simulaatioissa hyödynnettiin useita eri alueellisia ilmastomalleja sekä tulevaisuuden ilmastoskenaarioita. Vuosisadan loppuun asti ulottuvat tarkastelut osoittavat, että metsäpaloriski tulee kasvamaan tulevina vuosikymmeninä. Raportti korostaa myös metsäpalojen merkitystä mustan hiilen päästöille maailmanlaajuisesti, sekä mustan hiilen moninaisia terveys- ja ilmastovaikutuksia. Ilmakehän kulkeutumismallien mukaan Fennoskandian metsäpalojen vaikutukset mustan hiilen päästöjen osalta ovat kuitenkin pieniä ja keskittyvät erityisesti kesäkaudelle.

Tehokas metsäpalojen hillintä vaatii uudenlaisten havaintotyökalujen, kuten satelliittien sekä miehittämättömien ilma-alusten hyödyntämistä. Lisäksi uudet paloriski- ja leviämisennusteet yhdistettynä tarkkaan maasto- ja säätietoon tulevat olemaan tärkeitä apuvälineitä metsäpaloihin varautumisessa sekä operatiivista sammutustoimintaa suunniteltaessa. Metsäpalot ovat suuri haaste, joka vaatii sekä monitieteistä tutkimusta että eri sektorien, kuten pelastuslaitosten, sääpalvelun, metsäyhtiöiden ja metsänomistajien välistä läheistä yhteistyötä myös kansainvälisellä tasolla.

Julkaisijayksikkö

Sään ja ilmastonmuutoksen vaikutustutkimus

Luokitus (UDK)

356.13, 551.515.9, 551.577, 551.582, 551.583.16, 614.841.42, Metsäpalot, ilmasto, metsänhoito, 632.11 ilmastonmuutos

ISSN ja avainnimike

ISSN 0782-6079 Raportteja

ISBN

978-952-336-134-8 (nide)

978-952-336-135-5 (pdf)

\begin{tabular}{|l|l|l}
\hline $\begin{array}{l}\text { Kieli myös } \\
\text { englanti (tiivistelmä } \\
\text { suomeksi ja ruotsiksi) }\end{array}$ & $\begin{array}{l}\text { Sivumäärä } \\
156\end{array}$ \\
\hline
\end{tabular}


Joonas Kolstela, Mikael Kukkonen, Ilari Lehtonen, Maria Levina,

Henrik Lindberg, Päivi Mäkelä, Tero Partanen, Rami Ruuska, Jarno

Ruusunen, Ekaterina Shorohova, Laura Thölix, Ilkka Vanha-

Majamaa, Timo Virtanen, Jan Wahlberg

Rubrik: Klimatförändringar och skogsförvaltning påverkar skogbrandrisken i Fennoskandia

Skogs- och vildmarksbränder är en naturlig del av ekosystem över hela världen, men I synnerhet stora bränder kan förorsaka samhälleliga, ekonomiska och ekologiska störningar. Bränder är en betydande källa till växthusgaser och sot (black carbon) som ytterligare kan förstärka och påskynda klimatförändringen. Stora skogsbränder i Sverige under de senaste åren har visat att brändernas roll i klimatförändringen också bör beaktas i Fennoskandia. Denna slutrapport om projektet "Skogsbränder i Fennoskandia under föränderligt klimat och skogstäcke (IBA ForestFires)" finansierat av Utrikesministeriet sammanfattar aktuell kunskap om förekomst, övervakning, modellering och bekämpning av skogsbränder i Fennoskandia. Rapporten fokuserar också på att redogöra skogsbrändernas roll som källa till utsläpp av sot över Arktis och diskutera vikten av internationellt samarbete för att bekämpa skogsbränder.

Rapporten går igenom de faktorer som reglerar antändning, spridning och intensitet av bränder i Fennoskandia. Rapporten lyfter fram att klimatet i Fennoskandia kännetecknas av stor variation mellan år, vilket återspeglas i skogsbrandrisken. I detta område orsakas majoriteten av skogsbränder av mänskliga aktiviteter, som slarvig hantering av eld och antändningar relaterade till skogsavverkning. Förutom väder och klimat påverkar bränslets egenskaper brändernas antändning, intensitet och spridning. I rapporten presenteras långsiktig brandstatistik för Finland, Sverige och Republiken Karelen. Informationen sammanställdes från olika källor, bl.a. från statliga och privata skogar samt räddningstjänster. Statistiken visar att arealen skog som årligen brinner i Fennoskandia har minskat dramatiskt under de senaste hundra åren. Under de senaste 25 åren har den årligen brända arealen och antalet brander varit relativt stabilt, vilket främst beror på effektiva brandriskbegränsande åtgärder.

Vegetationsmodeller användes för att undersöka hur klimatförändringar och skogsförvaltning kan påverka skogsbränder i framtiden. Simuleringarna genomfördes med hjälp av data från olika regionala klimatmodeller och växthusgasutsläppsscenarier. Simuleringar, som sträcker sig till 2100, indikerar att skogsbrandrisken sannolikt kommer att öka under de kommande decennierna. Rapporten belyser också att skogsbränder globalt är en betydande källa till sot i Arktis. Sot har negative hälsoeffekter och förstärker ytterligare uppvärmningen av klimatet. Simuleringar gjorda med hjälp av en atmosfärisk dispersionsmodell indikerar dock att skogsbrändernas inverkan på miljön och luftkvaliteten är relativt liten och mycket säsongsbetonad.

En effektiv minskning av skogsbränder kräver utveckling av verktyg för att upptäcka skogsbränder, inklusive satelliter och drönare, samt modellering av brandrisk med hög upplösning som tar i beaktande detaljerad information om terräng och väder. Dessutom är det mycket viktigt att öka brandberedskapen i allmänhet samt effektiviteten i den operative brandbekämpningen. Skogsbränder är en stor utmaning som kräver tvärvetenskaplig forskning och nära samarbete mellan de olika administrativa aktörerna, t.ex. räddningstjänster, vädertjänster, skogsorganisationer och skogsägare, både på nationell och internationell nivå.

Publikationsenhet

Forskning av väder och klimatförändringens effekter

\begin{tabular}{|l|l|}
\hline Klassificering (UDK) & Nyckelord
\end{tabular}

356.13, 551.515.9, 551.577, 551.582, 551.583.16, 614.841.42, skogsbrand, klimat, skogsförvaltning, 632.11 klimatförändringen

ISSN ja och serietitel ISSN 0782-6079 Rapporter

\begin{tabular}{|l|l|l}
\hline ISBN & $\begin{array}{l}\text { Språk } \\
\text { engelska (sammandrag också på } \\
\text { 978-952-336-134-8 (volum) } \\
\text { finska och svenska) }\end{array}$ & $\begin{array}{l}\text { Sidantal } \\
156\end{array}$ \\
\hline
\end{tabular}


Publisher

Finnish Meteorological Institute

Erik Palménin aukio 1

P.O. Box 503

00101 Helsinki, Finland

Authors: Juha Aalto, Ari Venäläinen (eds.),

Tuula Aalto, Leif Backman, Anders Granström, Andrey

Report name and number

Reports 2021:3

Date

2021

Commissioned by

Ministry for Foreign Affairs of Finland

Gromtsev, Joonas Kolstela, Mikael Kukkonen, Ilari Lehtonen,

Maria Levina, Henrik Lindberg, Päivi Mäkelä, Tero Partanen,

Rami Ruuska, Jarno Ruusunen, Ekaterina Shorohova, Laura

Thölix, Ilkka Vanha-Majamaa, Timo Virtanen, Jan Wahlberg

Title: Climate change and forest management affect forest fire risk in Fennoscandia

Forest and wildland fires are a natural part of ecosystems worldwide, but large fires in particular can cause societal, economic and ecological disruption. Fires are an important source of greenhouse gases and black carbon that can further amplify and accelerate climate change. In recent years, large forest fires in Sweden demonstrate that the issue should also be considered in other parts of Fennoscandia. This final report of the project "Forest fires in Fennoscandia under changing climate and forest cover (IBA ForestFires)" funded by the Ministry for Foreign Affairs of Finland, synthesises current knowledge of the occurrence, monitoring, modelling and suppression of forest fires in Fennoscandia. The report also focuses on elaborating the role of forest fires as a source of black carbon (BC) emissions over the Arctic and discussing the importance of international collaboration in tackling forest fires.

The report explains the factors regulating fire ignition, spread and intensity in Fennoscandian conditions. It highlights that the climate in Fennoscandia is characterised by large inter-annual variability, which is reflected in forest fire risk. Here, the majority of forest fires are caused by human activities such as careless handling of fire and ignitions related to forest harvesting. In addition to weather and climate, fuel characteristics in forests influence fire ignition, intensity and spread. In the report, long-term fire statistics are presented for Finland, Sweden and the Republic of Karelia. The statistics indicate that the amount of annually burnt forest has decreased in Fennoscandia. However, with the exception of recent large fires in Sweden, during the past 25 years the annually burnt area and number of fires have been fairly stable, which is mainly due to effective fire mitigation.

Land surface models were used to investigate how climate change and forest management can influence forest fires in the future. The simulations were conducted using different regional climate models and greenhouse gas emission scenarios. Simulations, extending to 2100, indicate that forest fire risk is likely to increase over the coming decades. The report also highlights that globally, forest fires are a significant source of $\mathrm{BC}$ in the Arctic, having adverse health effects and further amplifying climate warming. However, simulations made using an atmospheric dispersion model indicate that the impact of forest fires in Fennoscandia on the environment and air quality is relatively minor and highly seasonal.

Efficient forest fire mitigation requires the development of forest fire detection tools including satellites and drones, high spatial resolution modelling of fire risk and fire spreading that account for detailed terrain and weather information. Moreover, increasing the general preparedness and operational efficiency of firefighting is highly important. Forest fires are a large challenge requiring multidisciplinary research and close cooperation between the various administrative operators, e.g. rescue services, weather services, forest organisations and forest owners is required at both the national and international level.

Publishing unit

Weather and Climate Change Impact Research

Classification (UDK)

356.13, 551.515.9, 551.577, 551.582, 551.583.16, 614.841.42, 632.11

Keywords

forest fire, climate, forest management, climate change

ISSN and series title

ISSN 0782-6079 Reports

ISBN

978-952-336-134-8 (print)

Language

English (abstract also in 156

978-952-336-135-5 (pdf)

Finnish and Swedish) 


\section{Preface}

Fire is a major natural disturbance agent in the boreal ecosystems, thus controlling ecosystem functioning and services. Recent extensive fires, often referred to as 'megafires', in e.g. Australia, California and the Siberian Arctic showcase how climate change may contribute to the occurrence and persistence of warm and dry weather conditions favouring the ignition and spreading of fires, with devastating societal and ecological impacts. However, climate is only one factor contributing to the fires - human activity such as land use, forest management, preventative actions and policies also play a key role.

In Fennoscandia, that is, the Scandinavian peninsula, Finland and north-west Russia, forest fires are common, but are relatively small and they usually do not cause wide societal disruption. However, the exceptionally large forest fires in Sweden in 2014 and 2018 demonstrated that northern countries should be prepared for fires that are now rare but are projected to become more prevalent due to climate change. This is also relevant in Arctic regions, as forest fires and other wildfires emit black carbon and other aerosols that are known to have significant climate and health implications.

Novel integration of the Earth observation and modelling systems combined with efficient and flexible local fire detection and suppression is needed to provide means for rescue services to tackle forest fires under a changing climate. Moreover, the changing forest cover and structure due to a shift in forest management towards uneven-aged practices and climate change-resilient tree species may alter the forests' fire characteristics, which needs to be accounted for in the planning of fire suppression. In addition to state-of-the-art technology, it is important that the emergency services, forest owners and companies, and planners have the most up-to-date understanding of the expected impacts of climate and forest change on forest fires. Crossboundary and transdisciplinary collaboration is needed to develop the means to tackle forest fires.

A vast amount of literature and data exists on forest fires in Fennoscandia. This report aims to synthesise current scattered knowledge of the occurrence, monitoring, modelling and suppression of forest fires in Fennoscandia (Fig. 1). In addition, we investigate how forest fires act as black carbon emissions sources over the Arctic. The results will help northern societies to prepare for the negative impacts of climate change and support the development of efficient mitigation and adaptation strategies over various sectors. In Fennoscandia, megafires are not the new normal. However, at these high latitudes, climate is changing faster than elsewhere, fostering suitable conditions for large fires. Therefore, we need to be prepared for the adverse effects of climate change, of which forest fires may have a greater impact on societies and nature than ever before.

In this report we use the term wildfire for an unintentional fire in an unbuilt area, and forest fire for a wildfire that occurs on forest land. It is notable that forest fires can also include grass fires, since some areas like clear-cuts and younger developmental stages of forests can be dominated by grass vegetation but are defined as forest land. Out of all wildfires, roughly half are forest fires in Sweden and Finland, but the area burnt in forest fires has been clearly greater recently (ca. 80\% of all areas burnt in wildfires in Sweden and ca. 60\% in Finland, respectively). Most of the wildfires that are not forest fires are grass fires in agricultural areas and occur typically during springtime. In this report, we concentrate on forest fires. 


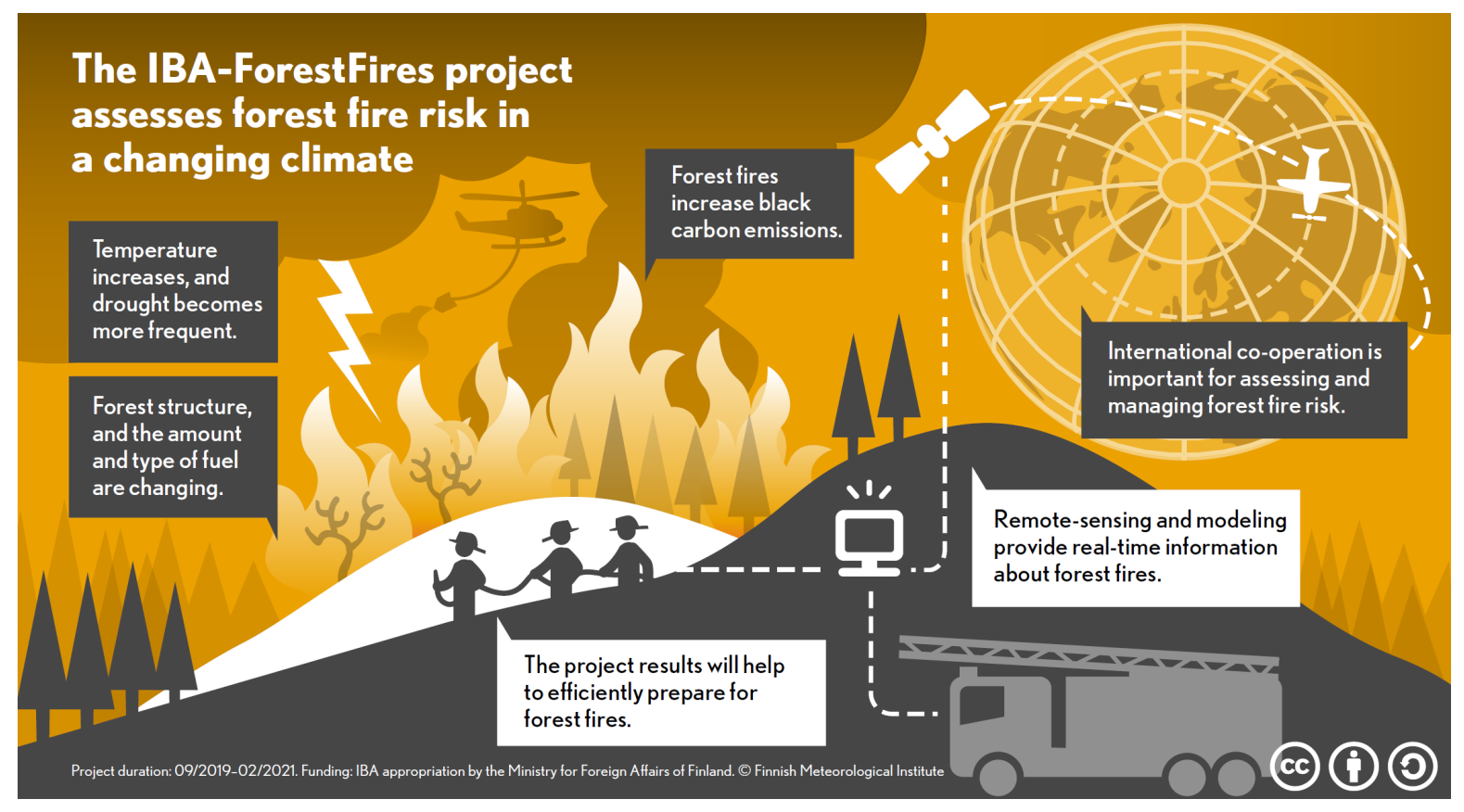

Figure 1. Infographics 'The IBA-ForestFires project assesses forest fire risk in a changing climate' summarises the main concepts of the project.

The report begins by explaining the key factors driving the ignition, spread and intensity of forest fires (chapter 2). Then, the most comprehensive time series of fire statistics across Finland, Sweden and the Republic of Karelia are presented (chapter 3). Due to differences in compiling statistics, it is important to understand that the presented fire statistics contain uncertainty and may not be directly comparable. Following a discussion on observed fire activity, the report moves on to elaborate the likely impacts of climate and forest cover change on multiple characteristics of forest fires using a set of climate and land surface models (chapter 4). Chapter 5 covers the broad topic of reducing the damage caused by forest fires. Here, the focus is on forest fire risk indices, surveillance from satellites and aircraft, fire propagation modelling, and the need for emergency services in building capacity and increasing preparedness for the future. In chapter 6 forest fires are described as a source of black carbon emissions based on atmospheric transport models. Finally, the importance of transnational climate and forest fire collaboration is highlighted in chapter 7.

This report is intended for scientists, policy makers, the forest sector and private forest owners, and for anyone interested in the past and future dynamics of forest fires. The report is part of the project "Forest fires in Fennoscandia under changing climate and forest cover" funded by the Ministry for Foreign Affairs of Finland IBA funding scheme, which promotes collaboration between the Baltic Sea, Barents and Arctic regions.

Helsinki, 07.06.2021

Juha Aalto, Research Professor, Principal Investigator

Ari Venäläinen, Senior Research Scientist

Finnish Meteorological Institute 


\section{TABLE OF CONTENT}

Preface

List of abbreviations $\quad 10$

1. Summary and recommendations $\quad 12$

2. The occurrence of forest fires depends on characteristics of forest fuels, $\begin{array}{ll}\text { weather, and human activities } & 17\end{array}$

3. The annually burnt forest area is relatively low in Fennoscandia 28

3.1 The impact of climate and human activities on forest fires can be detected in decadal-scale fire statistics $\quad 29$

3.2 The burnt area in Finland has decreased drastically since $1865 \quad 30$

3.2.1 Fire history studies in Finland $\quad 30$

3.2.2 Available forest fire statistics in Finland 31

3.2.3 Constructing time series for 1865-2020 32

3.2.4 Forest fires in Finland 1865-2020 32

3.2.5 Effective fire prevention and changes in land-use and forest structure explain the decline of burnt areas in forest fires 36

3.3 Fire regimes have changed substantially in Sweden over time 38

3.3.1. Fire history has been studied in various ways in Sweden 38

3.3.2. Organization of fire suppression then and now 41

3.3.3. Fire reporting 43

3.3.4. Fire causes and fire weather $\quad 44$

3.3.5. Fires that become large $\quad 47$

3.3.6 Trends into the future 48

3.4 In the Republic of Karelia, large year-to-year variation in the number of fires exists, and the average size of one fire is many times higher than in other parts of Fennoscandia $\quad 50$

3.4.1 Introduction $\quad 50$

3.4.2 Large inter-annual variability in fires across the Republic of Karelia 53

3.4.3 High annual variation in fire statistics in the Arkhangelsk, Leningrad and $\begin{array}{ll}\text { Murmansk regions } & 58\end{array}$

3.4.4. Russian fire statistics do not include all forest fires $\quad 60$

4. Climate change increases the risk of forest fires $\quad 66$

4.1. Increasingly severe fire weather creates more suitable conditions

for forest fires in the future $\quad 67$

4.2. Climate conditions and human influence determine the future fire regimes in $\begin{array}{ll}\text { Fennoscandia } & 70\end{array}$

4.2.1. Climate change and its effect on fire risk in Fennoscandia $\quad 70$

4.2.2. Future fire regimes in Fennoscandia $\quad 79$

4.2.3. Forest management influences on fire risk $\quad 85$ 


\section{Damages caused by forest fires can be reduced with technology, services, and community readiness}

5.1. Fire detection and modelling helps rescue services to fight forest fires

5.1.1. Forest fire risk indices describe the potential for dangerous fires

5.1.2. Surveillance from airplanes and satellites is needed to detect fires over sparsely populated areas

5.1.3. Fire propagation modelling simulates the spread of fire

5.2. Demand for rescue services amid changing climate and forest conditions

5.2.1 About the structure of rescue services in Finland in brief

5.2.2 Proportion and role of forest fires in rescue services operations

5.2.3 Forest fires from the perspective of rescue services - risk assessments at the national and regional level

5.2.4 Rescue and forest sector perceptions of forest fires - results of the survey

5.2.5 Future changes, challenges - and solutions

5.2.6. Smoke and fire! A case example of a forest fire and the extensive cooperation it requires: a forest fire in Pyhäranta in July 2018

6.1. Wildfires as the source of black carbon under climate change

6.2. Black carbon is harmful to health

6.3. Assessment of black carbon emissions from Fennoscandian wildfires

How to cite a chapter:

Vanha-Majamaa, I., Lehtonen, I., Lindberg, H., Shorohova, E., Venäläinen, A., Aalto, J. (2021). The occurrence of forest fires depends on characteristics of forest fuels, weather, and human activities. In Aalto, J. and Venäläinen, A. (eds.), Climate change and forest management affect forest fire risk in Fennoscandia. (pp. 17-27). Finnish Meteorological Institute Reports 2021: 3 . 


\section{List of abbreviations}

\begin{tabular}{|c|c|}
\hline AI & Artificial Intelligence \\
\hline $\mathrm{AOD}$ & Aerosol Optical Depth \\
\hline AVHRR & Advanced Very-High-Resolution Radiometer \\
\hline $\mathrm{BC}$ & Black Carbon \\
\hline BI & Burning Index \\
\hline BP & Before Present \\
\hline BUI & Buildup Index \\
\hline CAMS & Copernicus Atmosphere Monitoring Service \\
\hline CanESM2 & Canadian Earth System Model \\
\hline $\mathrm{CCI}$ & Climate Change Initiative \\
\hline CFFDRS & Canadian Forest Fire Danger Rating System \\
\hline CNRM-CM5 & Centre National de Recherches Météorologiques Climate Model \\
\hline CWD & Coarse Woody Debris \\
\hline $\mathrm{DC}$ & Drought Code \\
\hline DMC & Duff Moisture Code \\
\hline DSR & Daily Severity Rating \\
\hline $\mathrm{EC}$ & Elemental Carbon \\
\hline ECMWF & European Centre for Medium-Range Weather Forecasts \\
\hline EEA & European Environment Agency \\
\hline EECCA & Eastern Europe, Caucasus and Central Asia \\
\hline EGFF & EU Expert Group on Forest Fires \\
\hline ERC & Energy Release Component \\
\hline ESA & European Space Agency \\
\hline EUMETSAT & European Organisation for the Exploitation of Meteorological Satellites \\
\hline FBP & Fire Behaviour Prediction \\
\hline FDI & Fire Danger Index \\
\hline FFDI & Forest Fire Danger Index \\
\hline FFI & (Finnish) Forest Fire Index \\
\hline FFMC & Fine Fuel Moisture Code \\
\hline FIRMS & Fire Information for Resource Management System \\
\hline FMI & Finnish Meteorological Institute \\
\hline FRP & Fire Radiative Power \\
\hline FWI & Fire Weather Index \\
\hline GFDI & Grassland Fire Danger Index \\
\hline Glob-FIRM & Global Fire Model \\
\hline GPP & Gross Primary Production \\
\hline HNS & Host Nation Support \\
\hline $\mathrm{IC}$ & Ignition Component \\
\hline IR & Infrared \\
\hline ISI & Initial Spread Index \\
\hline IS4FIRES & Integrated System for Wildland Fires \\
\hline JSBACH & Jena Scheme for Biosphere-Atmosphere Coupling in Hamburg \\
\hline
\end{tabular}




$\begin{array}{ll}\text { JSBACH-FOM } & \text { JSBACH Forest Management } \\ \text { KBDI } & \text { Keetch-Byram Drought Index } \\ \text { LAPS } & \text { Local Analysis and Prediction System } \\ \text { LIS/OTD } & \text { Lightning Imaging Sensor/Optical Transient Detector } \\ \text { LPJ-GUESS } & \text { Lund-Potsdam-Jena Generalised Ecosystem Simulator } \\ \text { MIROC5 } & \text { Model for Interdisciplinary Research on Climate } \\ \text { MODIS } & \text { Moderate Resolution Imaging Spectroradiometer } \\ \text { NASA } & \text { National Aeronautics and Space Administration } \\ \text { NEFCO } & \text { Nordic Environment Finance Corporation } \\ \text { NFDRS } & \text { National Fire Danger Index } \\ \text { NI } & \text { Nesterov Index } \\ \text { NOAA } & \text { National Oceanic and Atmospheric Administration } \\ \text { NPP } & \text { Net Primary Productivity } \\ \text { NRT } & \text { Near-real-time } \\ \text { NWP } & \text { Numerical Weather Prediction } \\ \text { PM } & \text { Particulate Matter } \\ \text { PRONTO } & \text { Statistical Data System of Finnish Rescue Services } \\ \text { RCA5 } & \text { Rossby Centre regional climate model } \\ \text { RCP } & \text { Representative Concentration Pathway } \\ \text { SC } & \text { Spread Component } \\ \text { SDI } & \text { Soil Dryness Index } \\ \text { SILAM } & \text { System for Integrated Modelling of Atmospheric Composition } \\ \text { SLSTR } & \text { Sea and Land Surface Temperature Radiometer } \\ \text { SOP } & \text { Standard Operating Procedures } \\ \text { SPITFIRE } & \text { Spread and Intensity of Fires and Emissions } \\ \text { SSA } & \text { Single Scattering Albedo } \\ \text { SSP } & \text { Shared Socioeconomic Pathway } \\ \text { VIIRS } & \text { Visible Infrared Imaging Radiometer Suite } \\ \text { UAV } & \text { Unmanned Aerial Vehicle } \\ \text { WHO } & \text { World Health Organization } \\ & \end{array}$




\title{
1. Summary and recommendations
}

\author{
Juha Aalto, Tuula Aalto, Leif Backman, Joonas Kolstela, Ilari Lehtonen, Henrik Lindberg, \\ Päivi Mäkelä, Tero Partanen, Ilkka Vanha-Majamaa, Ari Venäläinen, Jan Wahlberg
}

Recent forest fires in regions such as Australia, the Amazon, Russia, Canada, California and Mediterranean countries have aroused a lot of publicity. Whereas forest fires are a natural part of many ecosystems, 'megafires' are most often ignited by humans and they can cause large societal, economical and ecological disruption. Fires are also an important source of greenhouse gases that further amplify and accelerate climate change. Forest fires emit black carbon and other aerosols that are known to have significant climate, air quality and health implications. Forest fires are a global challenge, but regional information exchange and cooperation are needed for effective mitigation and adaptation.

In Fennoscandia, that is the Scandinavian peninsula, Finland and north-west Russia forest fires are typically small, and they do not cause wide societal disruption. However, the present situation cannot be taken for granted. This was demonstrated by the exceptionally large forest fires in Sweden in 2014 and 2018. It is noteworthy that in Fennoscandia, climate change is proceeding at a pace that is exceeding the global average. Consequently, the suitable weather conditions for large forest fires are projected to become more prevalent due to climate change. This report synthetizes current knowledge of the occurrence, monitoring, modelling and suppression of forest fires in Fennoscandia. In addition, the report focuses on elaborating the role of forest fires as black carbon emissions sources over the Arctic.

The key findings of this report can be summarised as:

Key message 1: In Fennoscandia forest fire frequency and behaviour depend on weather, forest structure and human actions, especially fire suppression

- In Fennoscandia most forest fires are caused by human activities; lightning causes ca. $10 \%$ of fires, yet the portion of burnt areas and larger fires caused by lightning is notably higher. Here, human activities refer mainly to careless handling of fire and ignitions related to forest harvesting, and especially mechanical site preparation often carried out after final fellings.

- In addition to climate, fuels, i.e. forest characteristics and vegetation influence fire ignition, intensity and spread. For example, paludified Norway spruce forests do not ignite as easily compared to dry Scots pine-dominated forests. However, more flammable pine forests often result in low-intensity surface fires which are easier to control and suppress.

- In Fennoscandia, the climate is characterised by large variability that is reflected in forest fire risk - during wet summers there are practically no high fire-risk days, whereas during years of high fire risk, dry conditions can last several weeks.

\section{Key message 2: The amount of burnt forests has decreased in Fennoscandia}

- During the past ca. 150 years the amount of annually burnt forest area has decreased dramatically in Fennoscandia. This can largely be explained by the large societal change that has taken place, as forests became a valuable source of raw material in the 19th century which led to increased efforts to prevent forest fires. In Finland the decrease 
was especially steep after the Second World War, whereas in Sweden the decline occurred earlier. After the decline, in the latter half of the 20th century and in the first decades of the third millennium, the burnt area has remained at approximately the same level, except for some extreme fire years in the Republic of Karelia and in Sweden.

- Over the past two decades no clear changes in the number of forest fires can be detected.

- Long-term fire statistics are associated with high uncertainty and they are not directly comparable. These data are based on various sources and estimation methodologies, which may have changed over the years and can be different in each region under investigation. Therefore, it is likely that some of the observed variability in the annually burnt area and number of forest fires as well as regional differences can be explained by the differences in methods for compiling statistics.

\section{Key message 3: Climate change increases the risk of forest fires}

- Climate change projections indicate that forest fire risk will increase during the coming decades and the fire season will lengthen in both spring and autumn. However, severe fire seasons in Fennoscandia are likely to remain rare unless the worst warming scenarios come true.

- In Fennoscandia, the climate change is likely to increase forest fire risk, and ignitions are likely to become more frequent. However, the area burnt, fire intensity and greenhouse gas emissions are also influenced by forest management practices and fire suppression actions, so the future fire regime ${ }^{1}$ cannot be predicted only by climatic factors.

- In general, there is a considerable amount of uncertainty related to the future projections of forest fires mainly related to human activities and precipitation trends. Moreover, climate change may increase various abiotic and biotic risks to forests such as drought, tree uprooting, and damage caused by bark beetle outbreaks, which can increase the amount of dead wood in forests and increase forest fire risk.

\section{Key message 4: Damage caused by forest fires can be mitigated with new technology,} services, and community readiness

- Efficient forest fire prevention and suppression is crucial. Large forest fires may cause massive property damages, and health risks (fire, smoke emissions) for both rescue personnel as well as local people. Large fires endanger vital infrastructure, such as traffic connections, power, and telecommunication lines.

- From the rescue services point of view, forest fires form a laborious share of their operations. Especially large and/or simultaneous forest fires also restrict standby readiness and resources available for other incidents. Extinguishing forest fires and mopping-up (i.e. post-extinguishing) is laborious and involves a large amount of personnel and equipment. Firefighting equipment is mainly designed for construction fires.

- Satellite remote sensing can be used to detect and monitor forest fires in near real-time.

- Rescue and other operations can be facilitated with quad bikes, drones, and fire spread models.

- In sparsely populated areas, there are fewer people to detect fires. The average age of firefighters has increased.

\footnotetext{
${ }^{1}$ The role of fires in a defined area and during a selected time period, which summarizes the various impacts of fire on landscape, characterized e.g. by the frequency, size, intensity and severity of fires.
} 
Key message 5: Forest fires are a significant source of black carbon in the Arctic, but fires in Fennoscandia only have local effects on the environment and air quality

- Globally, black carbon (BC) is a strong climate forcer that absorbs solar radiation in the atmosphere, affects cloud formation and changes the surface reflectance when deposited to the snow and ice surface, further amplifying climate warming. Exposure to $\mathrm{BC}$ has adverse health effects when inhaled and can be linked to respiratory and cardiovascular diseases and mortality, for instance.

- Forest fires are the largest source of $\mathrm{BC}$ in the Arctic during the summer season. Anthropogenic sources, such as gas flaring, contribute to $\mathrm{BC}$ emissions throughout the year.

- The impacts of Fennoscandian forest fires on the environment and air quality over the Arctic are small, localised and highly seasonal compared to $\mathrm{BC}$ emissions from global forest fires. In the future, BC emissions are expected to increase along with the projected increase in the number of forest fires and burnt areas.

Key message 6: Arctic and Baltic cooperation on climate change and forest fires is important and should be strengthened in the future

- Forest fires are a large challenge requiring multidisciplinary research and close cooperation between the various administrative operators, e.g. rescue services, weather services, forest organisations, and forest owners at both national and international levels.

- Currently, international cooperation is realised in bilateral agreements and operational assistance when circumstances are critical, and resources are available. The most common way of assisting is to use aerial firefighting, while ground forces can also be used.

- Forest fire mitigation and the reduction of black carbon emissions benefits international cooperation at regional (e.g. Arctic forums), continental (e.g. Europe) and global levels.

Based on this report, the following recommendations can be made:

\section{Fire statistics:}

- In the future, efforts should be made to harmonise the compilation of statistics, so comparable fire statistics throughout Fennoscandia could be produced. Such data is invaluable in understanding the present and future variability in forest fires.

- Analyses of the drivers and variability of different forest fire regimes in different parts of Fennoscandia should be conducted. This information would allow the development of local measures to mitigate and suppress forest fires in the future.

\section{Assessing future fires:}

- The full range of uncertainty when projecting future fire risk arising from climate models, socio-economic development, forest management and forest fire suppression actions should be addressed.

- The latest scientific understanding of the anticipated impacts of climate change on forest fires on the development of mitigation and adaptation actions over various sectors, such as forestry operators, forest owners, rescue services and health, should be implemented. 


\section{New technological avenues:}

- The current international fire spread models should be tested and fine-tuned for Fennoscandian circumstances. This includes the integration of high-resolution terrain and weather data to the models, with the aim of using them in practical firefighting in the near future. Online fuel maps with data connections to firefighting vehicles should be constructed. Increasingly accurate LIDAR-based forest inventory and microclimate data provides prominent new opportunities in fuel mapping, for example, assessing local fire risk and finding demarcation lines in the terrain.

- Earlier fire detection by satellites or artificial intelligence (AI) helps in preventing larger-scale fires. Fire spread modelling systems allow for more optimised firefighting resource allocation and may potentially increase firefighter safety. Systems such as these are already used globally, but local adoption requires substantial further development.

- The potential of rapidly developing unmanned aerial vehicle (UAV) -related technology should be fully utilised in forest fire detection and forest firefighting.

\section{Operational firefighting and collaboration:}

- The decreasing rural population impairs forest firefighting capacity over wide areas. This challenge should be taken seriously since the quick response time is a key factor in determining whether fires will escalate into large ones. A dense network of fire stations and recruitment for contracted fire brigades is also crucial in the future.

- Fighting forest fires involves significantly more acute hazards than previously thought (e.g. carbon monoxide poisoning, carcinogens). In the future, occupational safety can be increased in real-time by the monitoring of biometric parameters. Health risks also emphasise investing in less labour-intensive strategies of firefighting, e.g. aerial firefighting, extinguishing tanks connected to forest machinery, etc.

- Fighting numerous and large simultaneous fires requires good coordination and leadership at a regional, national, and international level. Joint development and training actions are needed, as well as the development of situation and command centre operations.

- The general preparedness and operational efficiency of firefighting should be evaluated in the light of the past large fires in Sweden.

- Multichannel public safety communication and raising awareness of risks is essential in preventing forest fires. The identification of the risks of nature tourism is vital, because these activities are usually located in sparsely populated areas with sparse road networks (for instance national parks). Using the threat of sanctions is a way to intervene in undesirable actions: intentional and negligent behaviour.

- It is vital to understand the importance of preventative measures in tackling forest fires.

- New ways to develop multi-sectoral, national, and international collaboration on forest fire issues should be constantly sought.

\section{Black carbon:}

- More research is needed to understand the climate impacts of black carbon. For example, there are large uncertainties in understanding the mechanisms that control the distribution and properties of $\mathrm{BC}$-containing particles in the atmosphere and on snow 
and ice. In addition, the radiative forcing of black carbon due to the interaction with clouds is uncertain, especially over Arctic areas.

- Due to the severe negative impacts black carbon has, it is important that emissions caused by forest fires and the burning of fossil fuels are mitigated as efficiently as possible. 


\title{
2. The occurrence of forest fires depends on characteristics of forest fuels, weather, and human activities
}

\author{
Ilkka Vanha-Majamaa, Juha Aalto, Ilari Lehtonen, Henrik Lindberg, Ekaterina Shorohova, Ari \\ Venäläinen
}

In Finland, dry conditions with very high forest-fire risk occur simultaneously over most parts of the country approximately once per decade, on average (Venäläinen et al., 2016). In dry summers, the number of fires is many times larger than in wet summers. For example, since the mid-1990s, the annual number of all wildland fires has varied in Finland between approximately 1000 and 6000 (Lehtonen and Venäläinen, 2020) and in Sweden between approximately 2500 and 8500 (Sjöström and Granström, 2020), whereas the number of forest fires has been about half that of all wildfires. A small majority of the fires in Fennoscandia have been grassland, shrub and heathland fires, but the fires in forested environments are responsible for the majority of the burnt area, yet in Norway the area burnt in shrub and heathland fires is greater (Hylen, 2018). During the past 50 years, the development of fire suppression tools and techniques and thus effective fire suppression, together with intensive forest management and the construction of dense forestry road networks, has resulted in a clear reduction of the annually burnt area in Fennoscandian countries (Lindberg et al., 2020). For example, in Finland the average fire size in recent decades has been less than 1 ha, whereas in north-western Russia the average size can be almost ten times higher (see chapter 3). In this chapter we will briefly discuss the factors regulating fire ignition, spread and intensity in Fennoscandian conditions (Fig. 2.1).

\section{The occurrence of forest fires depends on weather, forest fuels, and human activities}



Figure 2.1. Infographics 'The occurrence of forest fires depends on weather, forest fuels, and human activities' summarising the main concepts of the chapter. 
Ignition. The fire ignition triangle is often used to describe the elements needed to start a fire: oxygen, heat and fuel. Oxygen is needed to start and sustain combustion, and its supply is increased by windy conditions. Heat is needed to raise fuel temperatures to their ignition point, and eventually to ignite fuels. Fuel is needed to sustain and carry flames. Combustible materials in forest fires include trees, understorey trees, shrubs, understorey vegetation, ground layer fuels, duff and peat. The ignition risk varies during the fire season and between different forest and vegetation types. The sources of ignition in forest fires are lightning and human activities. Fire ignition potential is largely determined by weather, i.e. wind, temperature, cloudiness, and moisture (Pyne et al., 1996; Johnson and Miyanishi, 2001). In Northern Europe, the distribution of lightning-ignited fires approximately follows thunderstorm climatology, with fewer ignitions in the north (Granström, 1993; Larjavaara et al., 2005a). However, lightning ignites only a small proportion of all forest fires as ever since human activities started, they have become the main reason for fire ignitions (e.g. Gromtsev, 2002). The share of ignitions caused by lightning strikes is nowadays approximately $8 \%$ of all wildland fires in Sweden and $13 \%$ in Finland (Granström, 1993; Larjavaara et al., 2005b), but it may increase due to climate warming (Kharuk et al., 2021). However, even nowadays lightning plays an important role in fire ignition in many areas, such as in Russian or Canadian boreal forests (Kourtz and Todd, 1991; Gromtsev, 2002). For example, in northern larch forests in Siberia, up to $90 \%$ of fires are caused by lightning (Kharuk et al., 2016). A large majority of the lightning-ignited fires occur during the most active thunderstorm season that extends from late June to early August (Mäkelä et al., 2014). In July, lightning can even be the most important cause of fires (Tanskanen and Venäläinen, 2008; Ganteaume et al., 2013; Lehtonen et al., 2016). The fires ignited by lightning strikes tend to be larger and more difficult to extinguish than human-caused fires. This is because human-caused fires are mostly concentrated near settlements, whereas lightning ignites fires in remote areas as well (e.g. Ganteaume et al., 2013; Calef et al., 2017).

Human-caused forest fires often result from careless handling of fire. One notable cause of human-induced fires are forest machinery operations, especially in stony terrain (Sjöström et al., 2019). In recent years, these fires have been responsible for approximately $40 \%$ of the area burnt in Sweden. Most ignitions associated with forest machinery operations are caused by site preparation with disc trenching. The main mechanism is likely to be high-inertia contact between discs and large stones. Sjöström et al. (2019) concluded that machine-caused forest fires could be largely avoided by cancelling operations in stony terrains during high-risk weather. In Finland, FMI has developed an application that allows for the assessment of suitable harvesting conditions, including Forest Fire Index (https://harvesterseasons.com/). Using less disturbing site preparation methods, such as mounding, the risk of ignition is significantly less, if not non-existent. Other reasons for human-caused fires include campfires, burning of litter and waste, discarded cigarette butts, use of matches, fire escape from prescribed burning, etc. (Ketola, 2018).

Most Fennoscandian forests belong to boreal and hemi-boreal vegetation zones (Ahti et al., 1968). The dominating tree species of Scots pine (Pinus sylvestris) and Norway spruce (Picea abies) form forest stands with different understorey vegetation composition. Some forest floor fuels, such as mosses (Hylocomium splendens, Pleurozium schreberi) and reindeer lichens (Cladonia spp.) do not have good water-holding capacity, and therefore their moisture content varies largely with weather conditions. Thus, they dry quickly and are important fuels for ignition and fire spread (Schimmel and Granström, 1997; Tanskanen, 2007). In Scots pine forests, the dominance of pleurocarpous mosses and occasionally lichens in the forest floor vegetation leads to higher ignition risk than in spruce forests, where lichens are much rarer. Lichens also dry more quickly than pleurocarpous mosses (Lindberg et al., 2021) and can 
therefore sometimes ignite more easily. Live ericaceous dwarf shrubs, such as lingonberry (Vaccinium vitis-idaea) or common blueberry ( $V$. myrtillus), typical in mesic and sub-xeric spruce or pine forests, are not very flammable. In drier and pine-dominated forests, more flammable heather (Calluna vulgaris) and crowberry (Empetrum nigrum), however, are more important fuels than other ericaceous dwarf shrubs (Lindberg et al., 2011). Moreover, sites and stands dominated by Norway spruce are typically rather moist compared to Scots pine stands, and also the dense canopy of spruces creates a humid microclimate (Tanskanen et al., 2006). Accordingly, Scots pine-dominated forests have a higher ignition potential compared to forests dominated by Norway spruce (Tanskanen et al., 2005). Thus, fire is a rarer phenomenon in spruce-dominated than in pine-dominated forests.

Ignition risk varies during the fire season. In early spring, the first fuels to dry off are dead leaves and cured grass in open areas; thus, grassland fires are common at this time of year. The most important cured grasses in the Fennoscandian forest environment are different Calamagrostis species and Deschampsia flexuosa. They belong to fine fuels and are often described as flash fuels, as they are extremely flammable. Fine fuels (smaller than $6 \mathrm{~mm}$ in diameter) typically dry quickly and are therefore important for fire ignition and spread. Their share and number in fuel load is therefore important. Fuels greater than $6 \mathrm{~mm}$ in diameter are called coarse fuels (Keane, 2015).

In forested environments, the ignition probability also varies considerably between different stages of seasonal vegetation development, being highest in the early fire season before the understorey vegetation is fully developed, especially in young and mesic forests (Tanskanen and Venäläinen, 2008) (Fig. 2.2). Ignition during the fire season generally requires a dry period, and is, besides ignition source, dependent on the moisture content variation and drying process of the fuels, especially fine fuels. Of the forest floor fuels in Fennoscandia, reindeer lichens (Cladonia) dry more quickly that the pleurocarpous mosses, of which Pleurozium schreberi and Hylocomium splendens dry more quickly than Dicranum species (Lindberg et al., 2021), thus contributing to the ignition risk. 


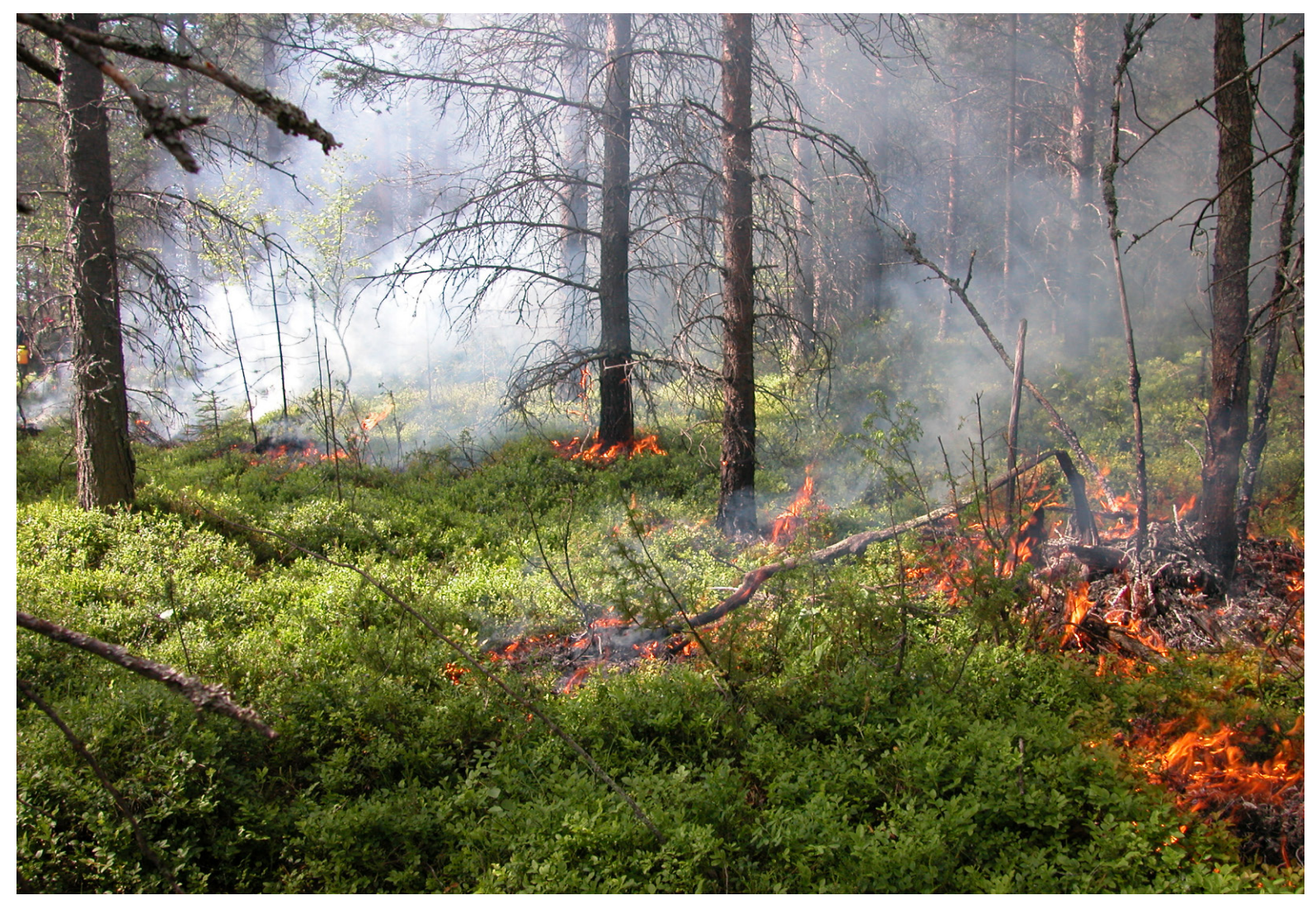

Figure 2.2. After a forest fire has ignited, it often spreads in various ways depending on available fuels. After crowning, burning crown fuels increase the number of spot fires outside the burning area. Martimoaapa, Keminmaa, Finland. Photo: Ilkka Vanha-Majamaa (2.7.2003).

Fire spread. Fire spread is a function of fuels, weather and topography, and could be called the fire behaviour triangle (Agee, 1993). All have significant effects on fire behaviour and spread, but the fuels are most related to forest structure, and are the only one of the three that can be controlled. Topography, slope and aspect affect fire spread. Changes in slope, aspect, elevation and soil affect available energy and water budgets and plant communities. These features also have a major influence on fire-caused disturbance through their role in determining moisture conditions and flammability of fuels on hourly, seasonal and successional timescales (Ryan, 2002). Natural fire breaks, such as large water bodies and peatlands, affect fire spread and lead to patchy fire occurrence (Wallenius et al., 2004). Landscapes with large areal coverage of peatlands compared to landscapes with less peatland differ significantly in their fire activity, with fires being larger and more common in landscapes with less peatland (Hellberg et al., 2004). Fires burn more rapidly when moving up a slope due to the preheating of unburnt fuels making them more combustible. Wind also moves more rapidly up slopes, increasing the speed at which a fire can spread. South- and west-facing slopes generally have drier fuels than north- and east-facing slopes. For example, in Finnish conditions, where the terrain is rather flat, topography is not that important a factor for increasing fire risk, whereas in Sweden and Norway the situation is somewhat different.

For fire spread, an increase in temperature is needed. Once fuels are ignited, heat is transferred in several ways. One way is conduction, but as forest fuels have low conductivity, this is not important in forest fire spread. Radiation transfers heat through air, preheating and dehydrating fuels to their ignition point. Most of the fire spread is caused by radiation. Convection transfers heat through the movement of liquid or gas. Fires generate gases that rise in columns, often 
with sparks, burning twigs or embers. Convective columns often move downwind and ahead of the fire front, starting spot fires. In high-intensity crown fires in particular, these are typical, and can spread fire over long distances (Alexander, 2006). In heat transmission, heat and smoke gases move along with the wind direction, steered by topography.

Forest fuels are mainly organic, consisting of live or dead plants. The fuel moisture content variation of dead fuels varies according to weather conditions. With live fuels the fuel moisture content variation is less, and not that much dependent on weather conditions. In Fennoscandian conditions, live fuels are not very flammable, but are still important, as they are the main component in crown fires, thus affecting fire spread. For example, needles of coniferous trees contain terpenes that have been shown to contribute to flammability, fire spread and even crown fire regimes (Dewhirst et al., 2020). Relatively small changes in the fuel moisture contents of the needles can increase crown fire risk and fire spread (Agee et al., 2002).

In boreal Scots pine and Norway spruce forests in Fennoscandia, the bush layer is typically not well developed and not very important for fire spread. The large amount of understorey saplings and lower spruce branches, however, facilitate fire spread to the crown layer (Fig. 2.3).

At the forest stand level, there are horizontal and vertical fuel components that affect fire spread, and at the landscape level, myriad patches of forest exist, each with a unique fuel structure that may carry fire along the surface or through the tree crowns (Ryan, 2002). The spread of fire at the landscape level can, and has been, largely controlled by past and present forest management that has increased fire breaks, such as forest roads, clear-cuts, sites with bioenergy removal, etc. In production forests, forest roads have two main ways of slowing down fire spread. For example, in Finland, where the forest road network is dense, they function as fire breaks but also allow fire brigades to fight fires more rapidly, thus affecting fire spread (see chapter 3 ).

From a fire management point of view, forest fire spread can be controlled by removing one side of the fire triangle: either oxygen, heat, or fuel. Fire breaks can be created by removing fuels in suitable spots, oxygen can be reduced by smothering flames with soil, and heat can be reduced with water or heat transfer through the use of fire retardants. In controlling fires, it is essential to suppress fire as quickly as possible after ignition, especially if the weather conditions are favourable for the vigorous spread of fire. The potential for large fires is thus highest in remote areas. On average, the fire size increases rapidly with increasing arrival time of the fire brigade from the moment the alarm is raised (Sjöström and Granström, 2020). For example, during the exceptionally warm and dry summer of 2018, the typical characteristics of the largest fires in Finland were that the fires occurred in contiguous and remote forest areas far away from settlements, trafficable roads and water bodies, and the first signs of the fires were smoke observations without a clear understanding of their origin (Ketola, 2018). 


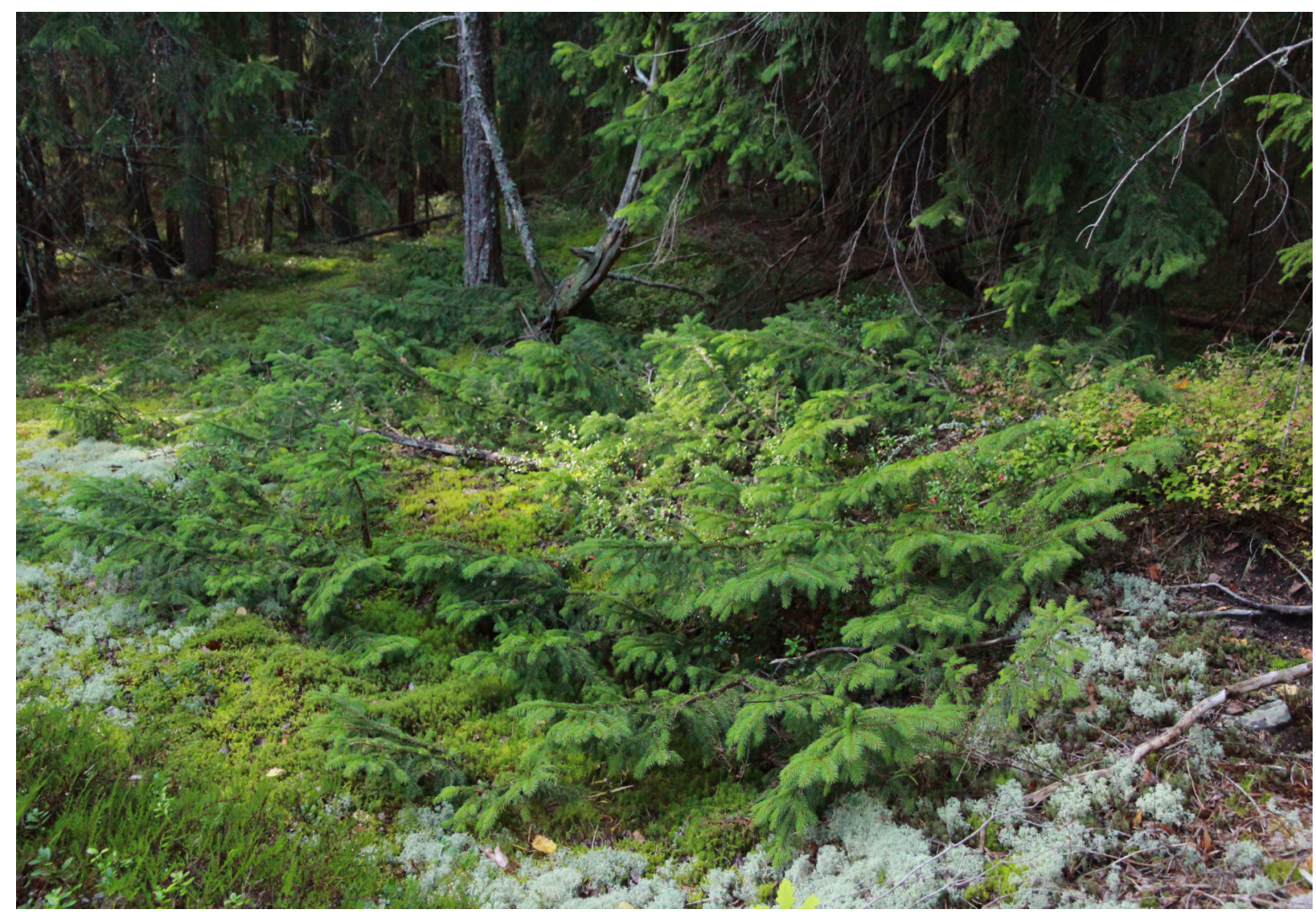

Figure 2.3. Typical boreal forest understorey vegetation with dwarf shrubs, lichens and polycarpous mosses. In case of ignition, low-lying branches of Norway spruce increase crowning risk. Hamari, Porvoo, Finland. Photo: Ilkka Vanha-Majamaa (16.8.2013).

Fire intensity. Fire intensity describes the physical combustion process of energy release from organic matter (Keeley, 2009). In physics, it is defined as a measure of the time-averaged energy flux or the energy per unit volume multiplied by the velocity at which the energy is moving. Byram's (1959) definition of fireline intensity has become a standard quantifiable measure of intensity (cf. Alexander, 1982; Van Wagner, 1983; Johnson, 1992; Agee, 1993; DeBano et al., 1998; Ryan, 2002). It is proportional to the flame length in a spreading fire and is a useful measure of the potential to cause damage to above-ground structures (Van Wagner, 1973; Alexander, 1982; Ryan and Noste, 1985). More broadly it can be measured as fireline intensity, temperature, residence time, radiant energy and others (Keeley, 2009). Rothermel's (1972) reaction intensity, which represents the heat source in his fire spread model, is consistent with this definition.

Fires can be classified according to their flame length as low intensity $(<1 \mathrm{~m})$, medium intensity $(1-3 \mathrm{~m})$ and high intensity $(>3 \mathrm{~m})$ fires, for example (Andrews and Rothermel, 1982). Fire intensity is dependent on the existing fuel load that can burn, its moisture content, and the weather conditions at the time of burning. On short time scales (minutes to hours), changes in the weather, specifically wind and relative humidity, significantly affect fire intensity. Different fuels have varying moisture-holding capacities, and finer surface fuels, for example, can become flammable during periods of warm and dry weather much more quickly than the organic layer in the soil (e.g. Van Wagner, 1974). Depending on the moisture content, consumption of the organic layer in surface fires can sometimes be very limited (Schimmel and Granström, 1997; Tanskanen et al., 2005; Lindberg et al., 2021). 
Normal seasonal changes in the dryness of the fuel load, its packing and possible periodic drought influence fire intensity (Ryan, 2002). In high-intensity wildfires, more extreme mortality will take place due to high rates of thermal energy coming from the flames, causing damage to the trees (Granström, 2001). An example of this type of fire was experienced in a mega-fire in south-central Sweden in 2018, when fire caused almost total mortality over a fire area of more than 13000 hectares (Gustafsson et al., 2019).

Fuels in Fennoscandian forests are heterogeneous and are hardly ever uniformly distributed, causing high variation in fire intensity (Fig. 2.4). Ground and surface fires are of much lower intensity and will generally not cause tree torching. Despite the relatively low flammability of spruce stands, Norway spruce is the most susceptible tree species in Northern Europe to burn explosively (Lindberg et al., 2011). Thus, spruce forests are susceptible to high-intensity crown fires, while in pine forests surface fires with much lower intensities are more typical.

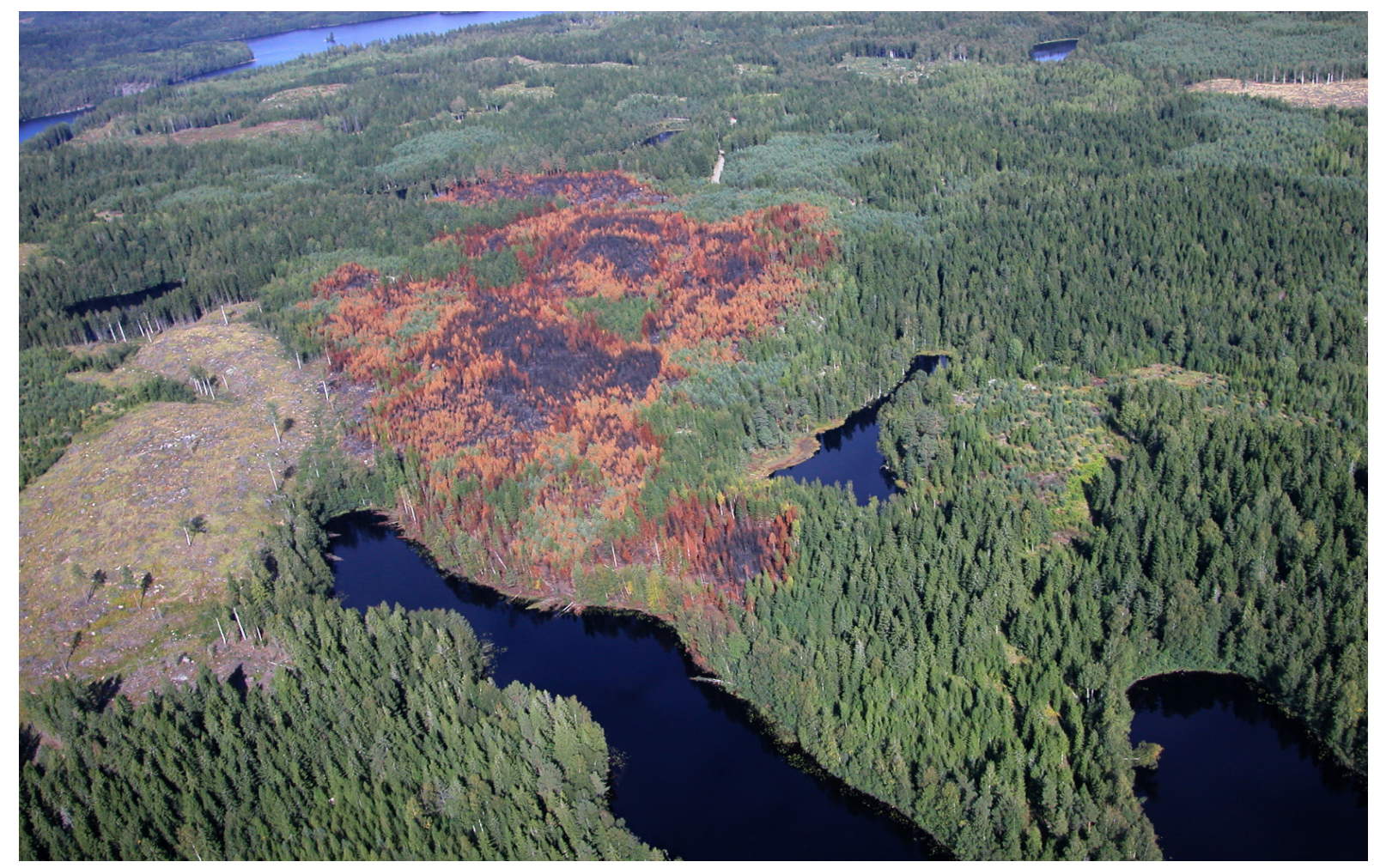

Figure 2.4. Patchy Fennoscandian forested landscape, with both natural fire breaks waterbodies of various size - and man-made fire breaks - e.g. clear-cuts of various size, and age. A burnt area of ca. 17 ha with ground, surface and crown fires. Kytäjä, Hyvinkää, Finland. Photo: Ilkka Vanha-Majamaa (3.9.2003).

The role of coarse woody debris (CWD) for fire intensity has not been studied much (but see review by Hyde et al., 2011), but it is likely to be higher in drier ecosystems with high amounts of CWD. With today's intensive forestry, CWD levels are low in Fennoscandian forests, except in pristine Russian forests (Shorohova and Kapitsa, 2015), and it can be assumed that the role of CWD for fire intensity is rather low. Logging slash induced in forest management operations mostly belong to fine fuels, and therefore can dry quickly and increase fire risk, and even fire intensity. Bioenergy removal of logging slash naturally lowers fire risk, spread and intensity (Agee and Skinner, 2005; Lindberg et al., 2011). 
Fire intensity is also dependent on fire interval. Longer fire intervals might be expected to result in more intense fire, due to a build-up of fuel. Over decades-long time scales, changes in vegetative structure affect the mass of fuel available for burning and therefore the potential energy that can be released during a fire. For the first 20 years after a forest fire, new fire spread in Fennoscandian conditions is unlikely due to the lack of suitable fuels (Schimmel and Granström, 1997). Later, from 20 to 50 years, fire intensity increases as an effect of changes in the amount of fuel, but after 50 years there seems to be no definite trend (Granström, 2001).

The utilisation of forests reduces fire intensity, as fuels are largely removed in various thinnings and regeneration cuttings. About $90 \%$ of forests in Finland, for example, are production forests of different ages, but are rather homogenous in structure. Together with the dense forest road network, creating fire breaks and enhancing fire suppression, this lowers fire intensity in case of ignition. Currently, there is a slow increase of continuous-cover forest management. From a forest fire point of view, continuous-cover forest management maintains fuel ladders and thus affects fire risk and fire intensity. In Sweden, where forest stands are typically larger, variation in topography is greater, and in north-west Russia, where the forest structures are more uneven in terms of age and structure, fire intensity can be much higher, partly explaining the recent fire statistics (chapter 3).

The principles of lower fire risk and fire intensity, such as reducing surface fuels, increasing the height to the live crown and decreasing crown density as suggested in North America (Agee and Skinner, 2005) have largely been normal practices in Fennoscandian forestry for about 60 70 years, which has lowered fire risk and fire intensity (Lindberg et al., 2011, chapter 3). Fires moving through production forests will have less chance of crowning potential and will therefore have lower fire intensity. It may be concluded that fire intensity can be lowered through the use of active management tools (firefighting, see chapter 5), and passive management tools (forest management, see chapter 3).

\section{References}

Agee, J.K. 1993. Fire ecology of Pacific Northwest forests. Island Press, Washington, D.C. 493 pp.

Agee, J.K., Wright, C.S., Williamson, N., Huff, M.H. 2002. Foliar moisture content of Pacific Northwest vegetation and its relation to wildland fire behavior. Forest Ecology and Management 167: 57-66.

Agee, J.K., Skinner, C. 2005. Basic principles of forest fuel reduction treatments. Forest Ecology and Management 211: 83-96.

Ahti, T., Hämet-Ahti, L., Jalas, J. 1968. Vegetation zones and their sections in northwestern Europe. Annales Botanici Fennici 5: 169-211.

Alexander, M.E. 1982. Calculating and interpreting forest fire intensities. Canadian Journal of Botany 60: 349-357.

Alexander, M.E. 2006. Models for predicting crown fire behavior - a review. In: V short course on fire behavior, 25-26 November 2006, Figuera fa Foz, Portugal. Association for the development of Industrial Aerodynamics, Forest Fire Research Center, Coimbra, Portugal: $173-225$.

Andrews, P.L., Rothermel, R.C. 1982. Charts for interpreting wildland fire behavior characteristics. USDA Forest Service, General Technical Reports, INT-131. 21 pp.

Byram, G.M. 1959. Combustion of forest fuels. In: Davis, K.P. (ed.). Forest fire: control and use. McGraw-Hill, New York, 61-89. 
Calef, M. P., Varvak, A., McGuire, D. 2017. Differences in human versus lightning fires between urban and rural areas of the boreal forest in interior Alaska. Forests 8: 422.

DeBano, L.F., Neary, D.G., Folliott, P.F. 1998. Fire's effects on ecosystems. John Wiley and Sons, New York. 333 pp.

Dewhirst, R.A., Smirno, N., Belcher, C.M. 2020. Pine Species That Support Crown Fire Regimes Have Lower Leaf-Level Terpene Contents Than Those Native to Surface Fire Regimes. Fire 3: 17.

Hellberg, E., Niklasson, M., Granström, A. 2004. Influence of landscape structure on patterns of forest fires in boreal forest landscapes in Sweden. Canadian Journal of Forest Research 34: 332-338.

Hylen, G. 2018. Skogbrann. I Tomter, S.M., Dalen, L. S. (red). Barekraftig skogbruk i Norge (2. ed.). Norsk institutt for bioøkonomi. [Forest fire. In: Sustainable forestry in Norway [In Norwegian].]

Ganteaume, A., Camia, A., Jappiot, M., San-Miguel-Ayanz, J., Long-Fourmel, M., Lampin, C. 2013. A review of the main driving factors of forest fire ignition over Europe. Environmental Management 51: 651-662.

Granström, A. 1993. Spatial and temporal variation in lightning ignitions in Sweden. Journal of Vegetation Science 4: 737-744.

Granström, A. 2001. Fire Management for Biodiversity in the European Boreal Forest. Scandinavian Journal of Forest Research 16: 62-69.

Gromtsev, A. 2002. Natural disturbance dynamics in the boreal forests of European Russia: a review. Silva Fennica 36: 41-55.

Gustafsson, L., Hannerz, M., Koivula, M., Shorohova, E., Vanha-Majamaa, I. Weslien, J. 2020. Research on retention forestry in Northern Europe. Ecological Processes: 9.

Johnson E.A. 1992. Fire and Vegetation Dynamics: Studies from the North American Boreal Forest. Cambridge University Press, New York. 129 pp.

Hyde, J.C, Smith, A.M.S., Ottmar, R.D., Alvarado, E.C., Morgan, P. 2011. The combustion of sound and rotten coarse woody debris: a review. International Journal of Wildland Fire 20: 163-174.

Johnson, E.A., Miyanishi, K. 2001. Forest fires: Behavior and ecological effects. Academic Press, San Francisco, CA. 594 pp.

Keane, R. 2015. Wildland Fuel Fundamentals and Applications. Springer International Publishing, Cham. 191 pp.

Keeley, J.E. 2009. Fire intensity, fire severity and burn severity: a brief review and suggested usage. International Journal of Wildland Fire 18: 116-126.

Kharuk, V.I.,_Dvinskaya, M.L., Petrov, I.A.,_Im, S.T., Ranson, K.J. 2016. Larch Forests of Middle Siberia: Long-Term Trends in Fire Return Intervals. Regional Environmental Change 16: 2389-2397.

Kharuk, V.I., Ponomarev, E.I., Ivanova, G.A., Dvinskaya, M.L., Coogan, S.C.P., Flannigan, M.D. 2021. Wildfires in the Siberian taiga. Ambio. https://doi.org/10.1007/s13280-02001490-x

Ketola, J. 2018. Hevonkuusessa palaa isosti - Tilastollinen selvitys kesän 2018 metsäpalojen leviämisestä. Pelastusopisto, Kuopio, $83 \mathrm{pp}$. [There is a big fire in the middle of nowhere Statistical report on the spread of forest fires in the summer of 2018. Emergency Services Academy Finland [In Finnish].]

Kourtz, P.H., Todd, J.B. 1991. Predicting the daily occurrence of lightning-caused forest fires. Canadian Forest Service Publications, Information Report PI-X-112. 18 pp.

Larjavaara, M., Kuuluvainen, T., Rita, H. 2005a. Spatial distribution of lightning-ignited forest fires in Finland. Forest Ecology and Management 208: 177-188. 
Larjavaara, M., Pennanen, J., Tuomi, T. 2005b. Lightning that ignites forest fires in Finland. Agricultural and Forest Meteorology 132: 171-180.

Lehtonen, I., Venäläinen, A., Kämäräinen, M., Peltola, H., Gregow, H. 2016. Risk of largescale fires in boreal forests of Finland under changing climate. Natural Hazards and Earth System Sciences 16: 239-253.

Lehtonen, I., Venäläinen, A. 2020. Metsäpalokesä 2018 muuttuvassa ilmastossa poikkeuksellinen vuosi vai uusi normaali? Ilmatieteen laitos, Raportteja 2020:2, 26 p + Appendix. [Forest fire season 2018 in a changing climate - an exceptional year or new normal? Finnish Meteorological Institute Reports [in Finnish with abstract in English].]

Lindberg, H., Heikkilä, T. V., Vanha-Majamaa, I. 2011. Suomen metsien paloainekset - kohti parempaa tulen hallintaa. Metsäntutkimuslaitos, Vantaa, $104 \mathrm{pp}$. [Finnish forest fuels towards improved fire management [In Finnish with summary in English].]

Lindberg, H., Punttila, P., Vanha-Majamaa, I. 2020. The challenge of combining variable retention and prescribed burning in Finland. Ecological Processes 9.

Lindberg, H., Aakala, T., Vanha-Majamaa, I. 2021. Moisture content variation of ground vegetation fuels in boreal mesic and sub-xeric mineral soil forests in Finland. International Journal of Wildland Fire 30: 283-293.

Mäkelä, A., Enno, S.-V., Haapalainen, J. 2014. Nordic lightning information system: Thunderstorm climate of Northern Europe for the period 2002-2011. Atmospheric Research 139: 46-61.

Pyne, S.J., Andrews, P.L., Laven, R.D. 1996. Introduction to wildland fire. Second edition. John Wiley and Sons, New York. 769 pp.

Rothermel, R.C. 1972. A mathematical model for predicting fire spread in wildland fuels. USDA Forest Service, Research Paper INT-115. 40 pp.

Ryan, K.C., Noste, N.V. 1985. Evaluating prescribed fires. In: Lotan, J.E., Kilgore, B.M., Fischer, W.C., Mutch, R.W. (coords.) Proceedings, Symposium and Workshop on Wilderness Fire, 1983 November 15-18, Missoula, MT. USDA Forest Service, General Technical Report INT-182: 230-238.

Ryan, K.C. 2002. Dynamic Interactions between Forest Structure and Fire Behavior in Boreal Ecosystems. Silva Fennica 36: 13-39.

Schimmel, J., Granström, A. 1997. Fuel succession and fire behavior in the Swedish boreal forest. Canadian Journal of Forest Research 27: 1207-1216.

Shorohova, E., Kapitsa, E. 2015. Stand and landscape scale variability in the amount and diversity of coarse woody debris in primeval European boreal forests. Forest Ecology and Management 356: 273-284.

Sjöström, J., Plather, F. V., Granström, A. 2019. Wildfire ignition from forestry machines in boreal Sweden. International Journal of Wildland Fire 28: 666-677.

Sjöström, J., Granström, A. 2020. Skogsbränder och gräsbränder i Sverige. Trender och mönster under senare decennier. Myndigheten för samhällsskydd och beredskap. [Wildfires in Sweden - trends and patterns during recent decades. Swedish Civil Contingencies Agency [In Swedish].]

Tanskanen, H., Venäläinen, A., Puttonen, P., Granström, A. 2005. Impact of stand structure on surface fire ignition potential in Picea abies and Pinus sylvestris forests in southern Finland. Canadian Journal of Forest Research 35: 410-420.

Tanskanen, H., Granström, A., Venäläinen, A., Puttonen, P. 2006. Moisture dynamics of mossdominated surface fuel in relation to the structure of Picea abies and Pinus sylvestris stands. Forest Ecology and Management 226: 189-198.

Tanskanen, H. 2007. Fuel conditions and fire behavior characteristics of managed Picea abies and Pinus sylvestris forests in Finland. Dissertationes Forestales 40, Department of Forest Ecology, Faculty of Agriculture and Forestry. University of Helsinki. 72 pp. 
Tanskanen, H., Venäläinen, A. 2008. The relationship between fire activity and fire weather indices at different stages of the growing season in Finland. Boreal Environment Research 13: $285-302$.

Venäläinen, A., Lehtonen, I., Mäkelä, A. 2016. Laaja-alaisia metsäpaloja mahdollistavat säätilanteet Suomen ilmastossa. Ilmatieteen laitos, Raportteja 2016:3, Helsinki. 30 p. [The occurrence of weather conditions favouring widespread forest fires in Finland [in Finnish with abstract in English].]

Van Wagner, C.E. 1973. Height of crown scorch in forest fires. Canadian Journal of Forest Research 3: 373-378.

Van Wagner, C.E. 1974. Structure of the Canadian forest fire weather index. Department of the Environment, Canadian Forestry Service, Publication number 1333, Ottawa. 44 pp.

Van Wagner, C.E. 1983. Fire behavior in northern conifer forests and shrublands. In: Wein, R.W., MacLean, D.A. (eds.). The role of fire in northern circumpolar ecosystems. Scope 18. John Wiley and Sons, New York, 65-80.

Wallenius, T. H., Kuuluvainen, T., Vanha-Majamaa, I. 2004. Fire history in relation to site type and vegetation in Vienansalo wilderness in eastern Fennoscandia, Russia. Canadian Journal of Forest Research 34: 1400-1409. 


\title{
3. The annually burnt forest area is relatively low in Fennoscandia
}

\author{
Henrik Lindberg, Anders Granström, Andrey Gromtsev, Maria Levina, Ekaterina Shorohova, \\ Ilkka Vanha-Majamaa
}

Chapter 3 provides a synthesis of forest fire statistics from Finland, Sweden, and north-west Russia, with special emphasis on the Republic of Karelia. Statistics have been collected with different accuracy, which must be noted when comparing statistics between countries and decades. Notably, not all forest fires are included in the Russian data. In addition, some differences exist in the classification of forest land.

Some trends in different regions can be revealed (Fig. 3.1). In the 1960s and 70s, the area burnt has been largest in the Republic of Karelia. Fire statistics show that the burnt area has dramatically decreased both in Finland and Sweden since the $19^{\text {th }}$ century, yet at different time periods (see chapters 3.2 and 3.3). This decline, however, is not seen in the number of wildfires. The observed decrease in the annually burnt area can be attributed to enhanced fire suppression efficiency and changes in forest management. During the last decade there has been a clear increase in the area burnt in Sweden due to some exceptionally large fires. In the Republic of Karelia, the average fire size has remained at a higher level than in Finland and Sweden, although the Karelian statistics also indicate a slightly decreasing trend in the burnt area in recent decades. Possible reasons explaining the differences between regions are discussed in the chapter.

\section{The total area burnt has mainly remained low in Fennoscandia during the recent decades}

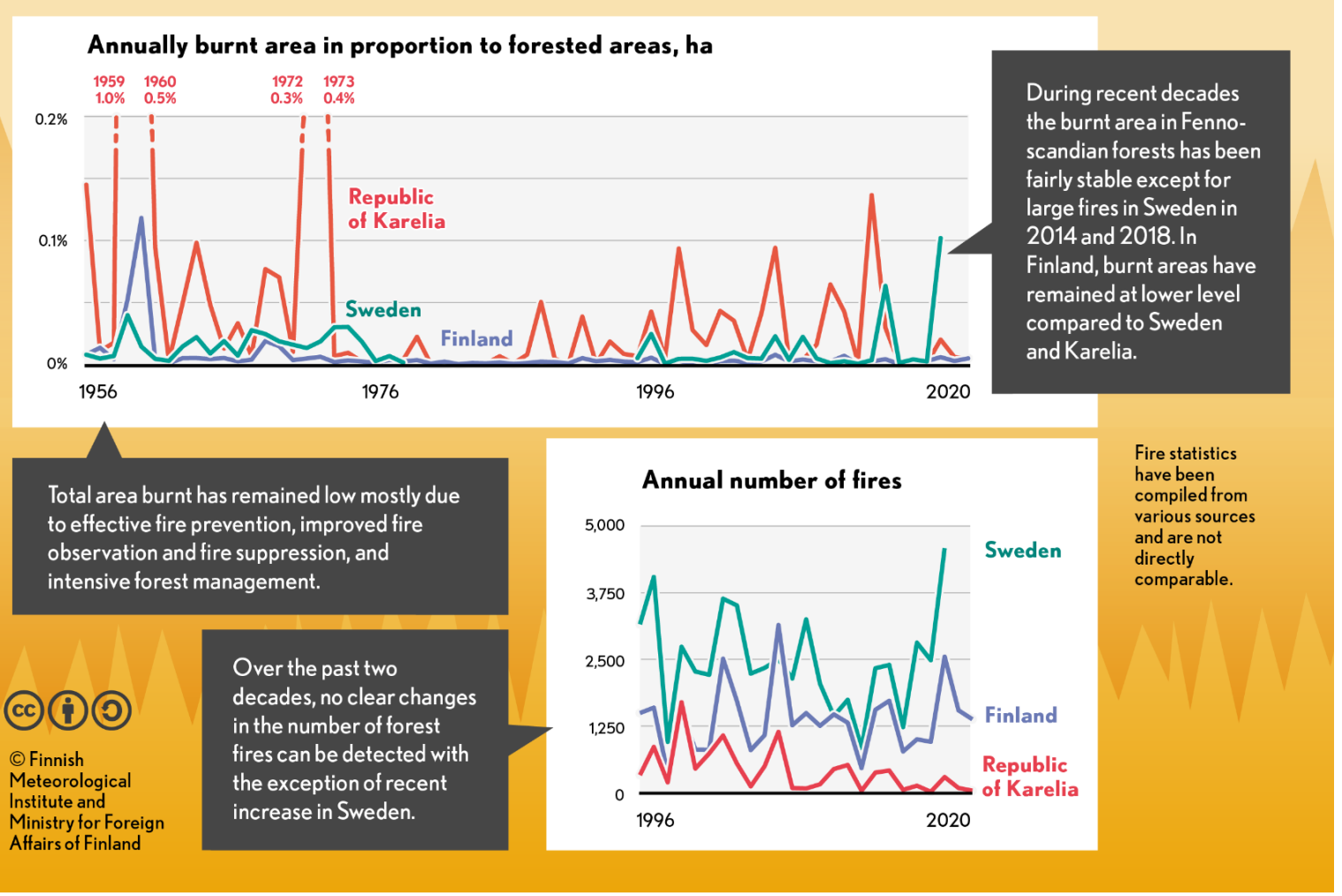

Figure 3.1. Infographics 'The total area burnt has mainly remained low in Fennoscandia during the recent decades' summarising the main findings of the chapter. 


\subsection{The impact of climate and human activities on forest fires can be detected in decadal-scale fire statistics}

During recent decades, fires have been suppressed efficiently and burnt areas have diminished. Past changes in forest fire dynamics can be largely attributed to changes in the human impact on fires. However, historical changes in fire activity can also be linked to climatic variations (e.g. Power et al., 2008; Olsson et al., 2010). Aakala et al. (2018) examined the relationship between fires and summer precipitation, air temperature and a drought index over a period ranging from the mid- $16^{\text {th }}$ century to the end of the $19^{\text {th }}$ century in eastern Fennoscandia. They found that climate had a clear impact on fire activity during this period, with a strong human influence on fires. More precisely, precipitation was identified as an important driver of multidecadal fire dynamics. Similarly, Drobyshev et al. (2016) have linked variations in precipitation to fire activity. Interestingly, they showed that years with large forest fires occurred in Scandinavia more frequently during cooler than warmer periods, particularly during the $17^{\text {th }}$ and $19^{\text {th }}$ centuries. They related this to coupled ocean-atmosphere dynamics that favour high pressure systems over Scandinavia during periods with low sea surface temperatures in the North Atlantic and expansion of sea ice cover in the Arctic. Although dry summers with large fires would occur more often during cooler than warmer periods, these summers could still be predominantly warm rather than cool. For example, all of the large fire years identified by Drobyshev et al. (2016) during the era of modern forestry statistics, i.e. 1901, 1933, 1959, 1969 and 2014, experienced relatively warm summers compared to long-term average conditions. Also, the summer of 2018, with its numerous large fires in Sweden, was exceptionally warm (Lehtonen and Venäläinen, 2020; Sjöström and Granström, 2020). Similarly, the summer with the highest number of forest fires and the largest burnt area within the last couple of decades in Finland, 2006, was much warmer than average (e.g. Lehtonen and Venäläinen, 2020). Moreover, Drobyshev et al. (2014) argued that fire regimes in northern and mid-boreal forests are more sensitive to climate variations compared to fire regimes in southern boreal forests.

Currently, the climate is becoming warmer due to increasing greenhouse gas concentrations in the atmosphere (IPCC, 2013). In Finland, the increase in the annual mean air temperature has been approximately $2{ }^{\circ} \mathrm{C}$ since the mid- $19^{\text {th }}$ century (Mikkonen et al., 2015). However, there has been no evident change in the fire proneness of Finnish forests matching this warming (Mäkelä et al., 2012). In the study by Mäkelä et al. (2012), long-term changes in forest-fire danger in Finland were examined during the main fire season of June-August from 1908 to 2011. Fire danger days were defined as days when a forest fire warning would be issued in the current operational system in Finland (see chapter 5.1.1). The average number of fire danger days in the southern part of the country was on average 29 in 1981-2010. The linear trend calculated over the whole period 1908-2011 indicated a slight but statistically insignificant decrease in the number of fire danger days. The variability of forest-fire danger is visualised in Figure 3.2 where the estimated annual number of fire danger days is shown for the period 18832020 in Jyväskylä in Central Finland. For example, summers 1883, 1928, 1961, 1981, 1987 and 2008 represent rainy and mainly cool summers, whereas summers 1917, 1937, 1947, 1951, 1955 and 2006 are examples of dry summers characterised by high numbers of fire danger days. In terms of fire activity, however, there have been significant changes in recent decades and centuries. Generally, in northern Europe, the number of fires started to increase after the mid17 th century in conjunction with increasing population density (Niklasson and Granström, 2000; Wallenius et al., 2004; Rolstad et al., 2017). Back in that time, fire was intentionally used to clear forests for pasture and cultivation. Later, a cultural transition to modern agriculture and forestry led to a steep decline in annual burnt area. In southern Scandinavia, the steepest decline in burnt area took place during the late $18^{\text {th }}$ century but in most of Fennoscandia, this did not 
occur until in the late $19^{\text {th }}$ century (Wallenius, 2011). This decline has been due to a decrease in average fire size, as thousands of forest fires still occur annually in northern Europe. For example, the average fire size in Finland in 1865-1870 in state-owned forests was as much as 131 ha, in 1891-1900 it was 77 ha, but in 1911-1920 it was not more than 28 ha (Parviainen, 1996). Nowadays, in Finland the average fire size is approximately 0.5 ha.
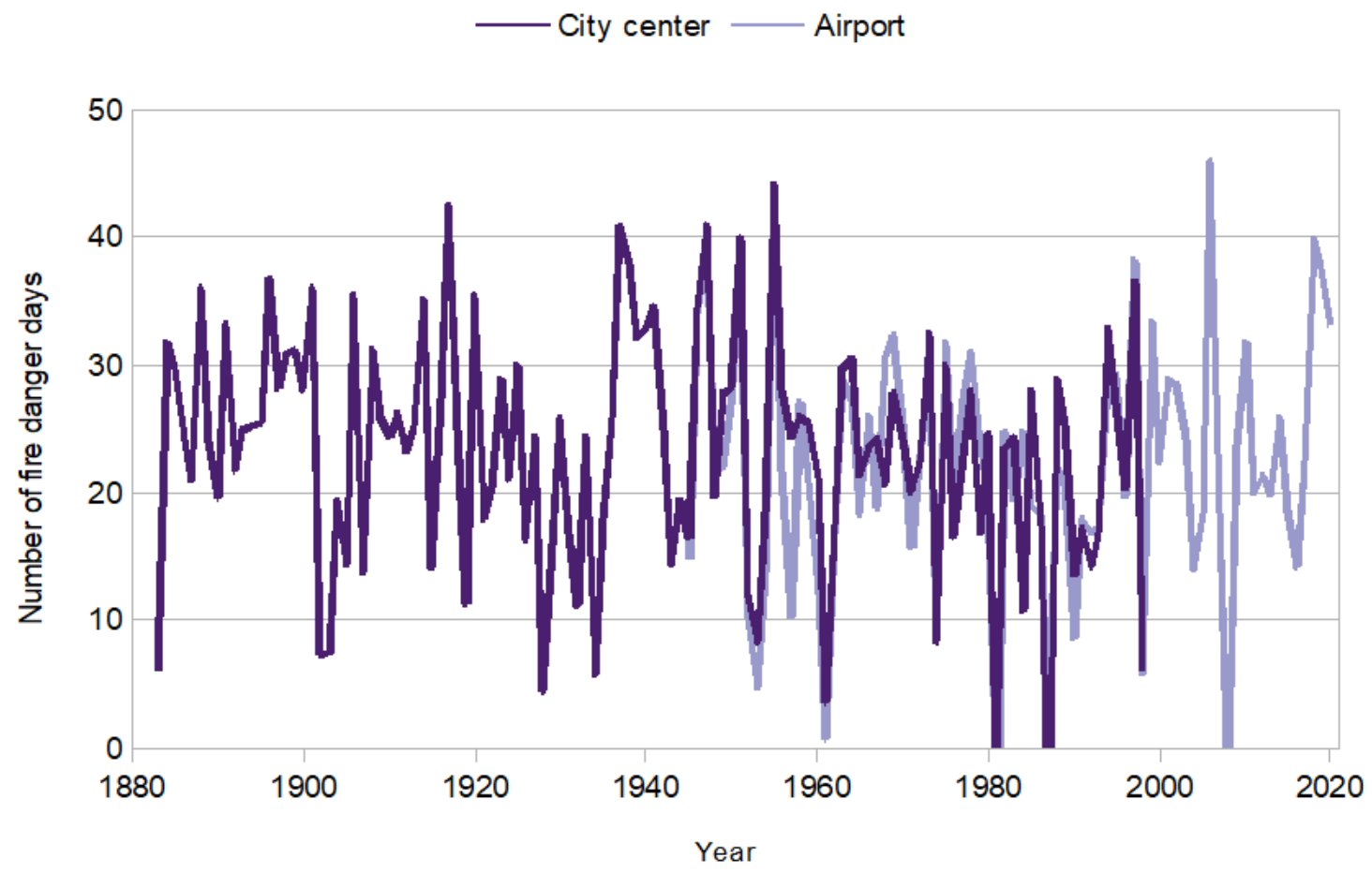

Figure 3.2. Number of fire danger days in Jyväskylä, Central Finland from 1883 to 2020 , estimated by June-August seasonal mean temperature and precipitation levels following the regression equation proposed by Mäkelä et al. (2012).

Clear et al. (2014) analysed the Fennoscandian forest fire history over the whole Holocene (i.e. the last ca. 11500 years). They concluded that early Holocene fires were driven by fuel availability; during the mid-Holocene (ca. 7000-5000 bp) thermal maximum, continental conditions increased fires, whereas the cooler and more humid climate and the spread of Norway spruce (Picea abies) during the mid-late Holocene reduced fires. Fires again increased during the late Holocene due to human influences such as slash and burn agriculture.

\subsection{The burnt area in Finland has decreased drastically since 1865}

\subsubsection{Fire history studies in Finland}

Similar to other studies dealing with boreal Fennoscandian fire history, studies from Finland show a large variation of fire intervals. In several studies focused on past centuries, short fire intervals of a few decades have been presented (Lehtonen et al., 1996; Lehtonen and Huttunen, 1997; Wallenius et al., 2007) as well as studies with intervals near 100 years (Haapanen and Siitonen 1978; Aakala 2018). The longest discovered intervals have been several hundred years (Wallenius et al., 2010; Aakala 2018). Larjavaara (2005) presented the longest cycle of 1700 years from Finnish Lapland, yet it was based on theoretical examination, not on empirical data as in the above-mentioned studies. 
In pine-dominated forests, especially in southern and central boreal forests, short fire intervals have been common, whereas in more northern and spruce-dominated forests they have been longer (Wallenius, 2004). The differences have also been explained by meteorological factors, dominant tree species, vegetation changes, fire suppression and general human influence (Wallenius, 2004; 2011). It must be noted that even in the same study, fire intervals can significantly vary depending on time period (Wallenius et al., 2007) as well as in areas close to each other (Aakala, 2018). In addition, the used methods are not directly comparable (see chapter 3.3.1), and it is noteworthy that practically all studies using the most reliable method, dendrochronology, have taken place in a time when human influence has been significant. They have also often been targeted at areas where (pine) trees with fire scars can be found, thus possibly directing the studies to dry, pine-dominated forests. Therefore, empirical fire history studies from relatively small areas should be treated as kinds of case studies and they should be generalised to larger areas with caution.

\subsubsection{Available forest fire statistics in Finland}

The systematic compilation of state forest statistics started soon after the establishment of Finnish Forest Service (Metsänhoitolaitos, later Metsähallitus) in 1859. The first annual statistics of state forests from 1865 already included a chapter on forest fires with numbers and sizes. The data on forest fires was collected from forest districts including the number and pooled size of burnt areas. The reliability of statistics is hard to estimate, yet according to the detailed descriptions and reports, it can be assumed that they have been compiled with care. However, the state forests were often situated in remote and roadless areas, so it is highly probable that many of the smaller forest fires and/or fires with low intensity in particular have not been recorded, particularly in the $19^{\text {th }}$ and early $20^{\text {th }}$ century.

Prior to 1952 there was no comparable systematic compilation of fire statistics from private forests. However, starting from 1916 statistical data concerning forest fires in privately insured forests are available. The share of insured forest rose steadily from less than $10 \%$ in the first years to more than $15 \%$ in the 1920 s and over $30 \%$ in the 1930 s (Lehmusluoto, 1956). In the late 1940s more than half of all private forests were insured. It is unclear how well the insured forests represent the forest fire regime of all private forests, yet Ennevaara (1954) found no significant differences between insured and non-insured forests in his comparison from 195253. It is notable that the insurance-based forest fire statistics report all forest fire damages that have resulted in insurance compensation. Thus, the number of reported incidents may not correlate with the true numbers of fires, since it is possible that one single fire can lead to several insurance compensation cases.

In 1952, a new national compilation system for forest fire statistics was launched, covering all forests (Ennevaara, 1954). Previously missing data from private forests was hereafter received from local authorities, between 1952 and 1978 from district forest boards and from 1979 to 1995 from the regional rescue authorities. From 1996 on, the compilation of forest fire statistics has been based on the national accident database PRONTO, maintained by Emergency Services Academy. The database contains data for all incidents attended by the local rescue services, including forest fires. As in Sweden, similar uncertainties related to estimates of burnt areas must be taken into account (see chapter 3.3.3). From 1968 to 2014 the forest fire statistics were published in annual Finnish Statistical Yearbooks and after that in Finnish Forest Statistics. The entire 1952-2019 time series of annual numbers and burnt areas of forest fires has recently been presented by Lindberg et al. (2020). 


\subsubsection{Constructing time series for $1865-2020$}

Using the sources explained above, we compiled a time series of annual forest fires for the time period 1865-2020. As a forest area, we used the area of productive forest land because the nonproductive forest land (low-productive land and wasteland) in Finland mostly consists of various moist or wet peatlands such as bogs, mires and swamps, which are significantly less prone to wildfires. According to estimates by Saari (1923) based on state forest statistics from 1911-1914, only 5\% of the area burnt in southern Finland occurred in peatlands and a negligible $0.2 \%$ in northern Finland.

Using data from private insured forests, we estimated the total area burnt on private productive forest land and applied this to all non-state-owned productive forest land (municipalities, parishes and companies). Similarly, we estimated the annual numbers of fires, yet this estimate can be notably biased (see above). For the period 1916-1951, we then summed these annual estimates representing all non-state forests with annual burnt areas from state-owned forest statistics to construct the national annual estimates of burnt areas and numbers of fires.

Since there was no data from private forests from the period 1865-1915, we interpolated annual values for non-state forests by using existing state forest and private forest data from the period 1916-1939 and state forest data from 1865-1915. The interpolation for private forests is average-based and does not take into account the fact that the ratio of burnt areas in state forests and private forests varied notably between years.

Finally, we combined the data from different sources into one time series, which consists of four parts with different origins: Part 1, 1865-1915 (Fig. 3.3, blue part of graph): statistical data from state-owned forests, interpolated values representing non-state forests, Part 2, 1916-1951 (red part of graph): statistical data from state-owned forests, estimates based on data from insured private forest for all non-state forests. Part 3, 1951-1978 (grey part of graph): national statistical data based on information provided by regional forest authorities, Part 4, 1979-1995 (yellow part of graph): national statistical data based on information provided by regional rescue services. Part 5, 1996-2020, (turquoise part of graph): national statistical data based on PRONTO database.

Since state forest data does not contain any estimates or interpolations, and can thus be considered more reliable, we also present the decadal averages for state forests and other forests separately up to 1978 when it was possible to separate them from statistics (Table 3.1).

\subsubsection{Forest fires in Finland 1865-2020}

The area burnt in forest fires in Finland has decreased from the annual average of 10 000-15 000 hectares in the late $19^{\text {th }}$ century and 1920 s and 1930 s to the current $500-600$ ha (Fig. 3.3, Table 3.1). During the time covered by the statistics, two periods of decline have occurred. The annual burnt areas decreased during the last years of the $19^{\text {th }}$ century. In the first two decades of the $20^{\text {th }}$ century the average annual burnt area decreased from over 10000 ha to 5000 ha. Yet, this decrease was temporary since during the next two decades the burnt areas increased again to a similar level. Especially during the 1920s, fire activity was high with several major fire years.

A rapid and drastic decline in burnt areas occurred in the 1950s and 1960s, especially given that the peak in 1960 is caused by an exceptionally large single fire in Eastern Lapland (Fig. 
3.3). This Tuntsa fire burnt a total of 120000 ha, 20000 ha on the Finnish side and 100000 ha in the Soviet Union (Haataja, 1993). The decline was particularly steep during the 1960s. In the 1950s the annual burnt area was still almost 6000 ha (and approximately 3500 without the Tuntsa fire), yet already in the 1970s it had dropped to an average of under 1000 ha and has stayed rather similar after that, with no increasing or decreasing trend in recent decades.

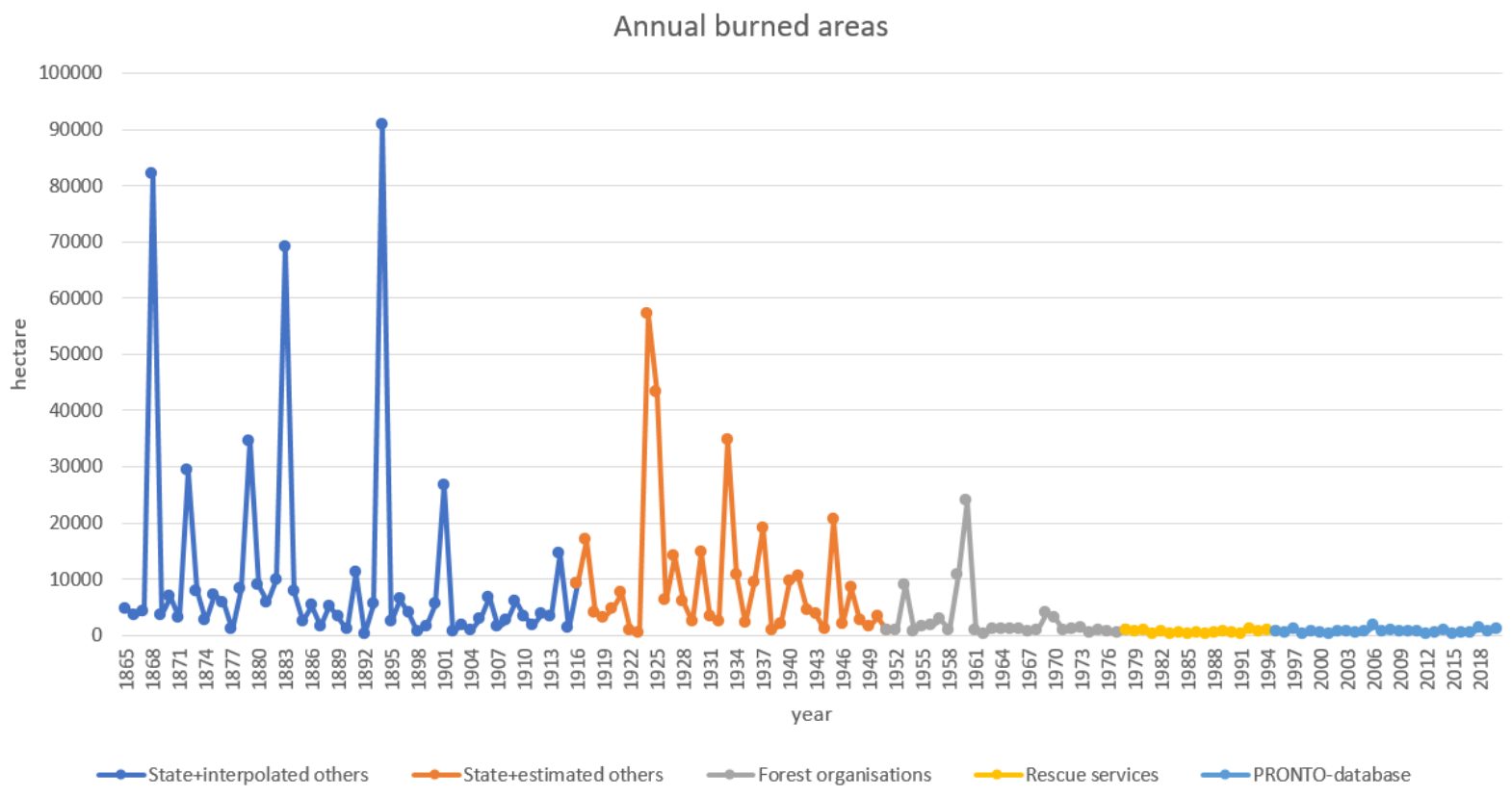

Figure 3.3. The annual areas (ha) burnt in forest fires in Finland during 1865-2020. The different colours refer to different data sources. See text above for details. 
Table 3.1. The decadal averages of annual burnt areas (ha), numbers (N), average (Avg.) sizes (ha) and calculated fire cycles (i.e. average fire intervals, years) in Finland in state and other (non-state) forests during 1865-2020 (for state and others 1865-1980, the last decade 19711978. The values for other (non-state) forests are based on interpolations for the period 1865 1915 and on data from insured private forests for 1915-1951.

\begin{tabular}{|c|c|c|c|c|c|c|c|c|c|c|c|c|}
\hline & \multicolumn{4}{|l|}{ All } & \multicolumn{4}{|l|}{ State } & \multicolumn{4}{|c|}{ Others } \\
\hline & Area & $\mathrm{N}$ & $\begin{array}{l}\text { Avg. } \\
\text { size }\end{array}$ & $\begin{array}{l}\text { Fire } \\
\text { cycle }\end{array}$ & Area & $\mathrm{N}$ & $\begin{array}{l}\text { Avg. } \\
\text { size }\end{array}$ & $\begin{array}{l}\text { Fire } \\
\text { cycle }\end{array}$ & Area & $\mathrm{N}$ & $\begin{array}{l}\text { Avg. } \\
\text { size }\end{array}$ & $\begin{array}{l}\text { Fire } \\
\text { cycle }\end{array}$ \\
\hline $\begin{array}{l}1865 \\
-70\end{array}$ & 17487 & 251 & 70 & 869 & 13764 & 105 & 131 & 577 & 3723 & 146 & 26 & 1947 \\
\hline $\begin{array}{l}1871 \\
-80\end{array}$ & 10808 & 321 & 34 & 1405 & 8507 & 134 & 63 & 933 & 2301 & 187 & 12 & 3150 \\
\hline $\begin{array}{l}1881 \\
-90\end{array}$ & 11111 & 304 & 37 & 1367 & 8707 & 127 & 68 & 899 & 2404 & 177 & 14 & 3063 \\
\hline $\begin{array}{l}1891 \\
-00\end{array}$ & 12770 & 290 & 44 & 1189 & 9330 & 121 & 77 & 665 & 3440 & 169 & 20 & 2612 \\
\hline $\begin{array}{l}1901 \\
-10\end{array}$ & 5276 & 211 & 25 & 2879 & 3407 & 88 & 39 & 1574 & 1869 & 123 & 15 & 5258 \\
\hline $\begin{array}{l}1911 \\
-20\end{array}$ & 6242 & 494 & 13 & 2433 & 3608 & 131 & 28 & 1557 & 2634 & 363 & 7.3 & 3822 \\
\hline $\begin{array}{l}1921 \\
-30\end{array}$ & 15181 & 594 & 26 & 1326 & 10796 & 185 & 58 & 762 & 4385 & 409 & 11 & 2971 \\
\hline $\begin{array}{l}1931 \\
-40\end{array}$ & 9383 & 890 & 11 & 2116 & 5376 & 117 & 46 & 1274 & 4007 & 772 & 5.2 & 3246 \\
\hline $\begin{array}{l}1941 \\
-50\end{array}$ & 5759 & 505 & 11 & 3146 & 3963 & 100 & 40 & 1312 & 1796 & 405 & 4.4 & 7064 \\
\hline $\begin{array}{l}1951 \\
-60\end{array}$ & 5276 & 496 & 11 & 3289 & 3722 & 81 & 46 & 1263 & 1555 & 415 & 3.7 & 7968 \\
\hline $\begin{array}{l}1961 \\
-70\end{array}$ & 1355 & 487 & 2.8 & $\begin{array}{l}13 \\
302\end{array}$ & 269 & 56 & 4.8 & $\begin{array}{l}16 \\
388\end{array}$ & 1086 & 431 & 2.5 & 11239 \\
\hline $\begin{array}{l}1971 \\
-80\end{array}$ & 727 & 559 & 1.3 & $\begin{array}{l}27 \\
375\end{array}$ & 146 & 86 & 1.7 & $\begin{array}{l}32 \\
410\end{array}$ & 581 & 472 & 1.2 & 21744 \\
\hline $\begin{array}{l}1981 \\
-90\end{array}$ & 312 & 471 & 0.7 & $\begin{array}{l}64 \\
325\end{array}$ & & & & & & & & \\
\hline $\begin{array}{l}1991 \\
-00\end{array}$ & 582 & 947 & 0.6 & $\begin{array}{l}34 \\
718\end{array}$ & & & & & & & & \\
\hline $\begin{array}{l}2001 \\
-10\end{array}$ & 642 & 1533 & 0.4 & $\begin{array}{l}31 \\
532\end{array}$ & & & & & & & & \\
\hline $\begin{array}{l}2011 \\
-20\end{array}$ & 586 & 1206 & 0.5 & $\begin{array}{l}34 \\
384\end{array}$ & & & & & & & & \\
\hline
\end{tabular}


Considering the number of fires, less fluctuation can be observed (Fig. 3.4). For the most part, the annual number of fires remained more stable through the examined time varying with both sides of 500 annual fires. However, a slight increase in the 1920s and 1930s can be observed. In the 1990s and especially during the first decades of the third millennium, a clear increase occurred. Since this it has been predicted that the fire risk in Finland will increase during the $21^{\text {st }}$ century (Kilpeläinen et al., 2010; Lehtonen et al., 2014b; Mäkelä et al., 2014), the increasing trend may be attributed to climate change. Yet it is probable that at least some part of the increase is explained by the change in compiling statistics. This is because from 1996 onwards the data has been received from the PRONTO database, which records all forest fire events where regional rescue services have been involved. It is thus likely that a notable number of formerly overlooked small fires could explain the increase. This interpretation is supported by the fact that during the period of use of the PRONTO database (1996-2020) no visible increasing trend can be seen (Fig. 3.5). Overall, regarding the entire time series, the number of fires contain so many uncertainties that they should be treated with caution and as merely directional.

\section{Annual number of forest fires}

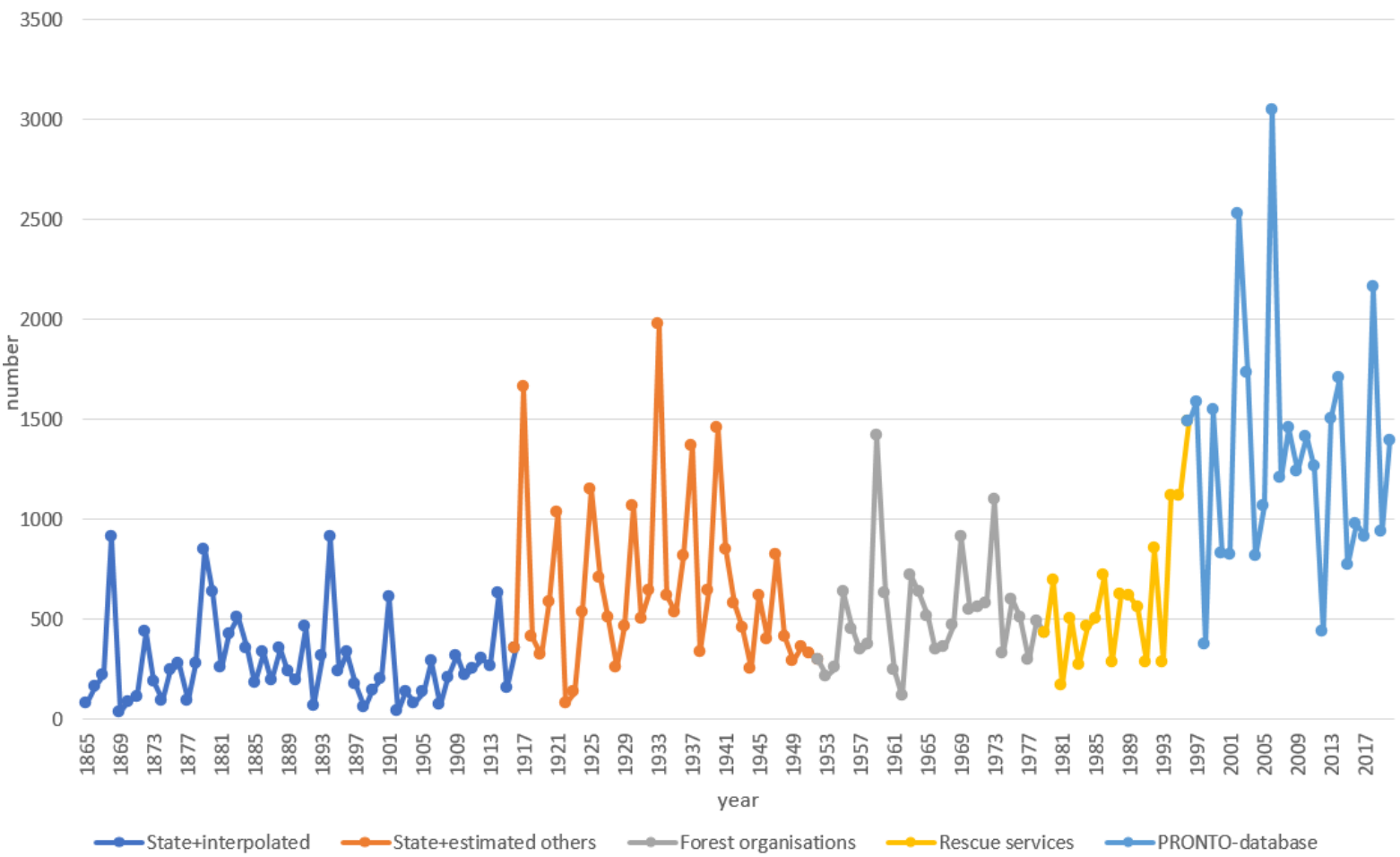

Figure 3.4. The annual numbers of forest fires in Finland, 1865-2020. Different colours as in Figure 3.3.

As a logical result from declined burnt areas and more stable amounts of fires, the average size of single burnt areas has also decreased. During the past five decades, the average size of a burnt area by a single fire has varied between $0.4-1.3$ ha (Table 3.1). With a general decrease in average fire size, large fires have also become rare. The last forest fire that burnt over 1000 ha took place in 1970 and after that only two fires exceeding 200 ha in size have occurred $(1997,2020)$. 




Figure 3.5. The annual numbers and areas burnt in forest fires during 1996-2020. Data source: PRONTO database.

\subsubsection{Effective fire prevention and changes in land-use and forest structure explain the decline of burnt areas in forest fires}

The decline in burnt area in the late $19^{\text {th }}$ century can most probably be explained by changes in the land use of forests. At that time, slash-and-burn agriculture was widely practised in Finland, and especially in south-eastern parts of the country, but this was already rapidly decreasing at this time. According to Heikinheimo (1915), the annual felled area for slash-and-burn cultivation decreased from 50000 ha in 1870 to less than 4000 ha in 1910. Slash-and-burn culture probably affected the fire regime in several ways. It is obvious that escapes from burnings were one of the main sources for forest fires. Heikinheimo (1915) notes that although it is impossible to quantify from statistics the true amount of forest fires caused by slash-andburn, they are often mentioned as primary ignition sources in older literary sources. The widely practised slash-and-burn culture also transformed the fuel structure in a less fire-prone direction. Abandoned slash-and-burn areas were usually regenerated to deciduous treedominated stands with less flammable understorey vegetation dominated by herbs and graminoids when compared to mosses and shrubs that are typical of mature coniferous forests. Slash-and-burn also reduced fuel loads in general, especially in areas near settlements where the burning rotation was short, leading to a barren landscape with a thin or even missing topsoil organic layer (Heikinheimo, 1915; Parviainen, 1996).

In the same time period, the industrial use of timber increased as first sawmills and soon after the pulp and paper industry needed increasing amounts of raw material. Timber started to gain in value and forest fires were considered more and more a threat to valuable property. Forest rangers were hired to guard state forests from 1859 and their education started in 1876 (Laitakari, 1960), with one of their main duties being forest fire prevention. 
Mäkelä et al. (2012) noted no significant increase in climatic forest fire risk in the period 19082011. The slight decrease in burnt areas in the 1930s could be partially explained by the increasing fire prevention activities presented by the Forest Fire Prevention Committee (Report of... 1926). These included, e.g. forbidding the use of open fires during dry and windy periods in the Fire Act (1933) and improving surveillance with fire guards, lookout towers and aerial patrolling performed by the Finnish Air Force (Soisalo, 2021).

After the Second World War, extensive fire prevention actions introduced earlier were put in practice on a large scale. The detection of fires in particular reached a new level of efficiency. The building of lookout towers continued at a rapid pace during the 1950 s and 60 s, reaching 131 in 1966 (Soisalo, 2021). After that they were soon replaced by regular aerial surveillance flights performed by local flight clubs and civilian aviators. Surveillance flights started experimentally in 1966, and still function as the main method of forest fire detection (see chapter 5). The updated Fire Act of 1960 included several actions concerning forest fire prevention such as the weather-based early warning system and surveillance duties directed by the forest authorities. Also, public guidance aiming to reduce forest fires was strengthened.

Soon after the Second World War, Finnish forest management practices were completely reevaluated, shifting management from exploitative selective cuttings towards intensive, compartment-based even-aged forestry by clear-cuttings with increasing artificial regeneration. The new forest management policies led to major structural changes at a stand and landscape level, reducing forest fire risk in several ways:

1. The massive clearcuttings meant that vast areas of former mature stands were turned into open regeneration areas and later sapling stands. In older pine- or spruce-dominated stands, a characteristic continuous moss or lichen carpet forms a potentially flammable layer where fires are ignited and spread (Schimmel and Granström, 1997; Tanskanen et al., 2005). Because of changes in incoming radiation over open and young stands, the moss carpet disappears (Tonteri et al., 2016), thus causing a temporal fuel discontinuity decreasing the fire risk (Schimmel and Granström, 1997), which is also supported by a growing abundance of less flammable herbs and graminoids.

2. The regeneration policies in the 1950s and 1960s favoured pine sowing and planting. Although the moss and lichen layer is known to dry faster in pine stands compared to sprucedominated stands (Tanskanen et al., 2005; Lindberg et al., 2021), the self-pruning of pine creates a vertical fuel discontinuity (Rogers et al., 2015) decreasing crown fire risk, resulting in low-intensity surface fires, which are easier to control and suppress.

3. The risk of crown fires was also reduced by pre-commercial and commercial thinnings, which decrease the crown density and fuel load. Formerly the most fire-prone stands were mixed pine-spruce stands (Saari, 1923) with uneven-aged structure. These stands were most often transformed into monocultural, even-aged pine stands. In fact, most of the fuel-reducing principles presented by Agee and Skinner (2005), among others, i.e. reducing surface fuels, increasing the height to living crown and decreasing the crown density, happened in Finland as a side product of post-war forest management.

4. Forest management transformed the former more uniform forest areas into a mosaic forest landscape with even-aged stands of different development classes. This decreased the horizontal fuel continuity which hinders the spread of fires and helps practical firefighting. 
5. The rapidly developing forest road network supported fire prevention. The roads were constructed for heavy timber trucks, also making them useful for firefighting vehicles. The efficient detection of fires and improved accessibility to forests provided by the new forest roads shortened the time to reach fires, thus helping to prevent them from escalating into large fires. Forest roads also function as existing fuel breaks, thus helping the suppression operations.

To summarize, the annual burnt area in Finland is currently around $4-5 \%$ that in the late $19^{\text {th }}$ century or the $1920 \mathrm{~s}$ and $30 \mathrm{~s}$. At the same time, the variability in the number of fires has decreased, especially when considering that the increase from 25-30 years ago is, at least partly, due to the change in the compilation of statistics. This suggests that the climatological risk of forest fires, which is likely related to the number of ignitions, has remained at relatively similar level with no increasing or decreasing trends as presented by Mäkelä et al. (2012). Thus, the drastic decline in burnt area that happened in the 1960s in particular must be explained by factors other than climatic ones. In addition to often-mentioned fire prevention, it is probable that forest management has also played a central role in decreasing fire risk (Päätalo, 1998).

The fire cycles presented in this study (Table 3.1) are notably longer than the respective fire intervals presented in fire history studies. Even in the state forests with periods of highest fire activity during the time series, the fire cycle was nearly 600 years and for all forests it ranged from less than 1000 years to a little over 3000 years before climbing to tens of thousands of years in the 1960s and 70s. It must also be noted that our comparison was based on productive forest land - if we had used all forest land, the values would be even higher. Thus, the fire cycle estimate of 400-500 years for the whole of Finland, for example (Parviainen, 1996), is likely to be low in light of our examination. However, Wallenius (2008) estimates that a decline in areas burnt in forest fires had already started in the early $18^{\text {th }}$ century, so it is possible that in earlier centuries the fire cycle was shorter. Moreover, according to Wallenius (2008), assessment grounded on Blomqvist's (1888) estimates results in a 1000-year-long fire cycle, which is quite close to our estimates from the late $19^{\text {th }}$ century (Table 3.1).

\subsection{Fire regimes have changed substantially in Sweden over time}

\subsubsection{Fire history has been studied in various ways in Sweden}

Sweden and the rest of Fennoscandia is dominated by forest vegetation that produces highly flammable fuel beds (Fig. 3.6), making fire an inherent component of this system and forcing land users to try to manage fire. As industrial forestry became the major form of land use in Sweden during the late 1800 s, there was a dramatic change in fire regime, parallel to what happened in the neighbouring countries of Fennoscandia: a gradual decrease in area burnt and a transition to a situation where fire was effectively controlled by available suppression forces. This sets Fennoscandia aside from several other regions of the circumboreal belt, in both North America and Eurasia, where fire is still a major threat to timber resources and infrastructure, despite considerable efforts at suppression (Gauthier et al., 2015). 

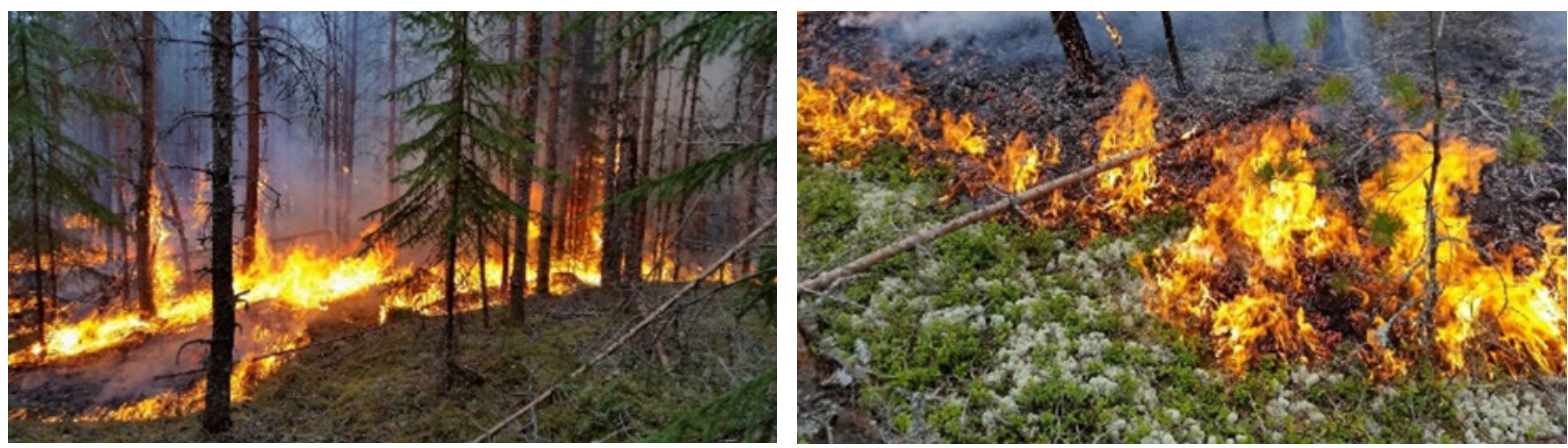

Figure 3.6. Left: Highly flammable surface fuel bed composed of the evergreen lingonberry (Vaccinium vitis-idea) and a mix of pleurocarpous mosses and reindeer lichens (Cladonia). After fire it takes approximately 30 years for it to fully regenerate. Right: Fennoscandian forests are heavily dominated by conifers, risking crown fire in high-danger weather conditions. Photo: Anders Granström.

There is relatively good information on the pre-industrial fire regime in Sweden, thanks to a high number of fire history studies, using cross-dated fire-scarred dead or living specimens of Scots pine (Pinus sylvestris) (Kohh, 1975; Zackrisson, 1977; Niklasson and Granström, 2000; Hellberg et al., 2004; Niklasson, 2011; Drobyshev et al., 2014). On a country-wide scale, southern sites tend towards shorter fire intervals (typically 30-50 years) in the pre-industrial era than northern sites (typically around 100 years).

As for the transition into the 'modern era' of very little fire impact, its timing appears to vary considerably between areas, although it is difficult to pinpoint when the transition took place based on the 'last' fire at individual sites, particularly when intervals before that were in the order of several decades. For some well-studied sites, it is clear that the transition happened surprisingly early. One example is Norra Kvill National Park in eastern Småland (Niklasson and Drakenberg, 2001), where a long series of short-interval fires (average 25 years) suddenly ended in the 1820s. Likewise, the Tyresta forest just south of Stockholm had an abrupt drop in fires in the late 1600s (Niklasson, 2011). However, at other well-studied sites in southern Sweden, the transition happened in the mid- or late $1800 \mathrm{~s}$, similar to the situation further north (Niklasson and Granström, 2000). In the inland north, the timing of the transition perfectly matches the organisation of 'professional' forestry, when a delineation of state forests was performed and forest companies acquired large land holdings from local farmers. This was accompanied by the deployment of foresters into even the most remote areas, with a duty to supervise the forest. Typically, a forester would also be put in command of the group called out to suppress wildfires.

Most fire history studies have dealt with one site or a collection of nearby sampling sites, which is adequate for information on fire intervals and fire impact at the local scale, but Niklasson and Granström (2000) also attempted to cover the spatial dynamics of past fires by sampling numerous positions within a large $(20 \mathrm{~km} \times 30 \mathrm{~km})$ landscape. This made it possible to map individual fire events. The study covered the period 1350 to the present day with reasonable detail and revealed substantial changes to the fire regime as early as in the late $1600 \mathrm{~s}$. Before that, fires were few but large. The two largest covered ca. 20000 and 35000 ha within the 60 000 -ha investigated area and extended outside of it for unknown distances. From around 1670 there was a marked increase in the number of fire events in the landscape, but at the same time the average size of fires decreased. This coincided with the establishment of a small number of 
homesteads in the region, which was previously inhabited only by a sparse population of Sami people.

One interpretation is that this shift marked a transition from a predominately natural fire regime characterised by a low number of mainly lightning-ignited fires, most likely centred on climatically favourable summers, to a predominantly anthropogenic fire regime with numerous wilfully or accidentally set fires, smaller than average and involving many more fire-years, implying less extreme climatic conditions on average. The settlers depended largely on animal husbandry (cows, goats and sheep) and various evidence suggests fire was used extensively to maintain good pasture (Granström and Niklasson, 2008). Interestingly, the area burnt per unit time did not increase in proportion to the increase in the number of fires on the landscape. As a consequence of the diminishing average fire size, the average fire interval was only shortened from 125 years prior to 1650 to 80 years in the period 1650-1870, despite the number of fires in the landscape increasing several times over. This in turn might reflect both a feedback mechanism due to fuel shortage in early succession, and active management decisions by the inhabitants as to when, what and where to burn. Similar spatio-temporal patterns were demonstrated within a 7400 ha forest landscape in Norway (Rolstad et al., 2017) and it is likely that such shifts have occurred throughout Fennoscandia but at different times.

Regarding the fuel-fire feedback, statistical analysis of the fire interval data from the 60000 ha area (Niklasson and Granström, 2000) revealed a gradually increasing probability of renewed fire disturbance over a ca. 50-year period, both pre- and post-1650. Fire intervals shorter than 15 years were extremely rare, presumably due to a lack of suitable fuels. This fuelfire feedback hypothesis is also supported by a study of fuel succession in boreal forests (Schimmel and Granström, 1997). As for the human control of fire size, more detailed mapping of fire events in the 1700s suggest strategic positioning of individual burn areas, with fuelbreaks such as small streams serving as borders (Granström and Niklasson, 2008). That type of active fire management should have been much helped by the fuel-fire feedback.

Inland northern Norrland is unique within Sweden, in that 'agricultural' settlement commenced as late as after 1670, thus making it possible to identify this transition towards a predominantly anthropogenic fire regime. Further south in the country it should have occurred several hundreds or thousands of years earlier with the expansion of settled agriculture, well beyond the time depth possible with dendro-analysis, which rarely reaches beyond 700 years. Also, studies focusing only on fire intervals, e.g. using charcoal analysis in sediments, would not be able to identify changes to the spatial display of fires and might therefore miss the transition towards an anthropogenic fire regime. Sediment-based studies can reach much further back in time but are notoriously difficult to interpret, and parallel studies of fire scars and sediment records have repeatedly failed to show a good match (Kasin et al., 2013). Charcoal in a sediment core is evidence of fire but a lack of charcoal is not good evidence for lack of fire.

Documenting past fire events using Pinus fire scars of course also entail potential bias. First, it is dependent on pines having been a component of the forest, second, that at least a few individuals survived the fire, and third, that they actually formed a fire scar (Piha et al., 2013). Therefore, it is not a given that a fire will leave traceable evidence on the trees on site. It is clear that fire history studies have been directed at sites with good recording-trees and that these sites are not random points in the forest landscape. For example, low-lying areas in the terrain tend to have soils that are more productive and spruce-dominated, and thus it becomes difficult to know if fire actually entered there or not. However, for a fire event to cover large parts of the landscape, non-flammable areas have to constitute only a minor part. Otherwise the fire 
would stop early. Recent experience from landscape-covering fires in Sweden (Granström, 2020) also show that most of the terrain within the fire perimeter was actually covered, i.e. leaving few fire refugia. Thus, little discrimination is expected if fires occur in severe drought, which is typical for lightning-ignited fires (Kinnman, 1936), and large fire events in general.

Drobyshev et al. (2014) compiled data from all available fire-history studies in Sweden to identify temporal synchronicity. They identified that a relatively limited number of years accounted for a very large proportion of all fire activity. Some of these years were countrywide, while others were more regional and they proposed a division of fire-climate synchronicity and control between the north and south of the country.

Fire intensity is one important aspect of the fire regime that is considerably more difficult to reconstruct for the past than fire intervals or areas burnt. Fire intensity is important because it determines resistance to suppression and because it controls the degree of tree-canopy damage. However, in a pine-dominated forest, fire is not necessarily detrimental to timber value. It should be noted that the 'timber frontier' that moved through Sweden from the mid-1800s (Östlund et al., 1997) exploited timber resources, often large-diameter Pinus sylvestris, that had developed under the fire regimes of previous centuries. In fact, on many sites of intermediate fertility, pine would owe its dominance to repeated low-intensity fires. The presence of extensive tracts with fire-scarred Pine stumps and other remnants is in itself testament to a regime of mainly sub-lethal fires. However, the picture is complex and has received little quantitative analysis (but see Östlund et al., 1997).

\subsubsection{Organization of fire suppression then and now}

Until recently, it was the responsibility of the local population to respond to wildfires. This was clearly outlined in medieval laws and in the 1734 law for Sweden (applicable also for Finland, then under the Swedish crown), it was stated that people close by should rush to the site and start combatting the fire. If not successful, a 'fiery cross' (Sw. Budkavle) should be passed through nearby villages with the obligation to send one man from each household to the site, with specified equipment (axe, bucket). Low-tech firefighting required large groups of people working in coordination and with strategic positioning of the attacks. Into the early 1900s, it was the responsibility of a designated fire official (Sw. Brandfogde) to organise the work.

Firefighting was organised separately for forest fires and for structural fires well into the $1900 \mathrm{~s}$. As roads and other infrastructure developed towards the mid-1900s, fire brigades of the municipalities started to be engaged in forest fires, in addition to their primary mission to perform structural firefighting. This process was gradual and started in the southernmost densely populated areas. As late as during the period 1945-1956, fire brigades accounted for less than $10 \%$ of total suppression costs in the northernmost province of Norrbotten and motor pumps were used only on 7\% of the fires (Anonymous, 1960).

The transition in firefighting from large local groups to small groups of professional firefighters has never been quantified in detail but was likely completed in the late 1970s. To be efficient, the latter system is dependent on rapid detection, good road access and use of motor pumps, primarily taking water directly from the fire engine, or from a local source if needed. Today this works fine for the vast majority of fires, since $88 \%$ are controlled to a size less than 0.5 ha (Sjöström and Granström, 2020). However, if the fire escapes the first responders, it then becomes very difficult to draw enough firefighters to the site, particularly if there are multiple ongoing fires. For example, in 2018 the $5600 \mathrm{~km}^{2}$ municipality of Ljusdal had a total of 17 
firefighters on standby and four simultaneous wildfires ignited by thunderstorms on the afternoon of 14 July. All available firefighters became engaged quickly, except one crew reserved for road accidents and other emergencies (Granström, 2020). Nearby municipalities were asked for additional resources, but they had none to spare.

It should be noted that the labour-intensive mop-up (post-extinguishing), performed once a fire is controlled, is still the responsibility of the landowner. This causes considerable problems today for all categories of landowners. Many small-scale landowners are either too old or live too far from their forest to be able to carry out this task, and this problem will likely only increase in the future with the projected depopulation of the countryside. Large forest companies on the other hand outsource the mop-up to contractors that otherwise work with forest plantation or pre-commercial thinning. These are the only two forestry tasks that are not fully mechanised today, and in case of a wildfire such crews are called in to do the mop-up. The vast majority of the personnel are migrant workers from the Baltic States and other eastern European countries. Typically, they have no wildfire training and often do not speak Swedish, which can cause communication problems. In the case of multiple fires, these crews can easily be overstretched.

It is the municipalities that are responsible by law to provide a rescue service, including wildfire suppression (although the law from 2003 [LSO] does not mention forest fires specifically anywhere in the text). Sweden presently has around 290 municipalities, ranging in population from 2500 to 700000 inhabitants. Today most municipalities have formed rescue service alliances with neighbouring municipalities to gain strength. A few of these encompass quite large areas (the largest is around $40000 \mathrm{~km}^{2}$ ). Rescue stations with full-time employed firefighters exist only in large and medium-sized cities. Most of the countryside is serviced by stations with part-time firefighters that have their ordinary work close by and are obliged to report to the station within five minutes in case of an alarm. The distance between stations is above $20 \mathrm{~km}$ in many rural areas, giving a median travel time to the fires of around 30 minutes for the inland north (Sjöström and Granström, 2020) and nearly 20\% are not reached within one hour. Each part-time fire station typically has the capacity to dispatch one crew of $1+4$ (one foreman and four firefighters), with three vehicles (one fire engine, one tanker and one ordinary car). In the case of a confirmed wildfire, often two or three crews are sent directly, implying two or three stations.

For the last 30 years or so, helicopters have been employed in firefighting in the country. Until recently, it was commonly assumed that incident commanders were reluctant to call in helicopter assistance from private firms in the early stages of an incident, because of high costs that would fall on the municipality. Military helicopters have always been cost-free to the municipalities, but rarely available on short notice. After the 2018 fires, a new system for aerial firefighting was commissioned and implemented by May 2019. The state pays for a national contract with a consortium of private helicopter companies. In case of high fire danger in any region, a total of 18 helicopters are put on standby for operation on short notice. When there is a fire, the incident commander can request helicopter assistance, but the decision is taken by central command at MSB (Swedish Civil Contingencies Agency) and the state pays for all flight hours. This will likely mean an increased use of helicopters in initial attack than before. Another initiative by the state was to issue a tender for two scooping fixed-wing firefighting airplanes. The contract was won by Saab which, since early 2020, has operated two Fire Boss planes from Nyköping in south-east Sweden. The planes can make drops of $3 \mathrm{~m}^{3}$ of water. This resource is offered as part of the joint EU Civil Protection Mechanism. A third step that might follow later, 
after an evaluation period, is to employ larger scooping planes (Canadair), again as part of the EU mechanism.

The majority of wildfires are initially spotted by members of the public and reported to the alarm centre. However, for decades, there has also been a surveillance system that uses small fire-spotting planes. These are most often operated by an amateur pilot together with a spotter in the cockpit. In case of high fire danger, the planes are called out to fly one or two preordained routes per day. Each loop takes 1-1.5 hours to complete. When a fire is spotted, they typically fly close, send coordinates to the alarm centre, take photos that are often sent directly to the fire brigade or alarm centre, and evaluate how serious the situation is. If the fire has already been reported, they can verify coordinates and often scout road access to help ground crews. The state pays for this fire detection system.

\subsubsection{Fire reporting}

Industrial forestry was accompanied by the collection of wildfire statistics (issued first in 1878), but it was not comprehensive to begin with. Proper reporting was restricted to the newly organised state forests (Högbom, 1934). Nevertheless, from their start, written fire records support the dendro-based analysis of a rapid drop in burnt areas during the last decades of the 1800s. More comprehensive data collection, including data from private forests, began in 1944 (yet there is preliminary data from all forests also from years 1942 and 1943) and was continued until 1975, with minor modifications. After each fire the responsible fire officer filled in a report card detailing location, landowner, fire cause and area burnt, under the two categories forest land and grassland. The card had prepaid postage and was sent to a government agency, who compiled the data and issued an annual report.

It has not been established why this reporting ended in 1975 but it coincided with an organisational change of the overseeing government agency. For a few years statistics on larger fires continued to be collected by the Bureau of Central Statistics of Sweden but was finally dropped after 1979. It appears this was due to the state no longer paying municipalities directly for the cost of forest fire suppression. Wildfire statistics again started to be collected in 1996 under the aegis of MSB (Swedish Civil Contingencies Agency) and continues today. It is voluntary for the approximately 290 Swedish municipalities (Sw. kommun) to contribute data, but today nearly all do. After each deployment, the incident commander files a report on location, suspected cause and burnt area in three categories (Productive forest including clearcuts, Other tree-covered land and Treeless land) and also adds a short text statement.

Two facts are worth mentioning regarding the statistics. First, the ignition-cause attribution has a low precision. Around 30\% are given as cause unknown and this was actually also the case in the previous, 1944-1975, reporting scheme. Further, the area estimate is very unreliable. It is usually done by an incident commander who is not trained in area estimates. In 1997, 23 burnt areas in the province of Västernorrland, stated to be larger than 1 ha, were area-measured on the ground, revealing large errors in the reported size. In most cases the area was overestimated (median 3.3 times). The largest wildfire (400 ha) was however correctly reported. It is likely that the size of very large wildfires is reported more accurately, since foresters are then usually on site towards the end of the operation and can supply adequate information. The area statistics for the 2018 fires are an exception from the general scheme, since all areas stated to be $>0.5$ ha in the incident reports were thoroughly delineated from satellite or aerial photographs by the Forest Agency (Sw. Skogsstyrelsen). Nevertheless, fire size data in the Swedish wildfire statistics should be treated with caution. 
Despite the less than perfect wildfire data for the 1900s, it is clear that area burnt is down to a tiny fraction of the situation in the mid-1800s and earlier. It is also clear that individual years stand out and that these years are characterised by long drought periods, when analysing monthly weather data (Drobyshev et al., 2012; Ou, 2017). It is interesting that for large parts of the 1900s, prescribed burning for site preparation on clear-felled areas covered much larger areas than wildfires. In some years of the 1950s and 1960s, areas in the order of 40000 ha were burnt (Forest Statistical Yearbook). Incidentally, this activity should also have provided an experienced workforce to act on wildfires. The area burnt in management fires declined precipitously from the late 1960s and started to increase again somewhat at the turn of the century, this time for biodiversity reasons (Granström, 2001), and at a much lower level. Statistics are again not comprehensive, but the area burnt today in management fires is likely 2000-3000 ha per year, i.e. on par with the area burnt in wildfires.

\subsubsection{Fire causes and fire weather}

A thorough analysis of all reported wildfires over the period 1996-2019 was done by Sjöström and Granström (2020), in which they matched daily weather data and fire danger indices (Canadian FWI-system, see chapter 5.1.1) to each incident and also looked at the geographic distribution of both fires and fire weather. The analysis revealed strong spatial gradients in both the number of forest fires and average fire weather within the country (Fig. 3.7).

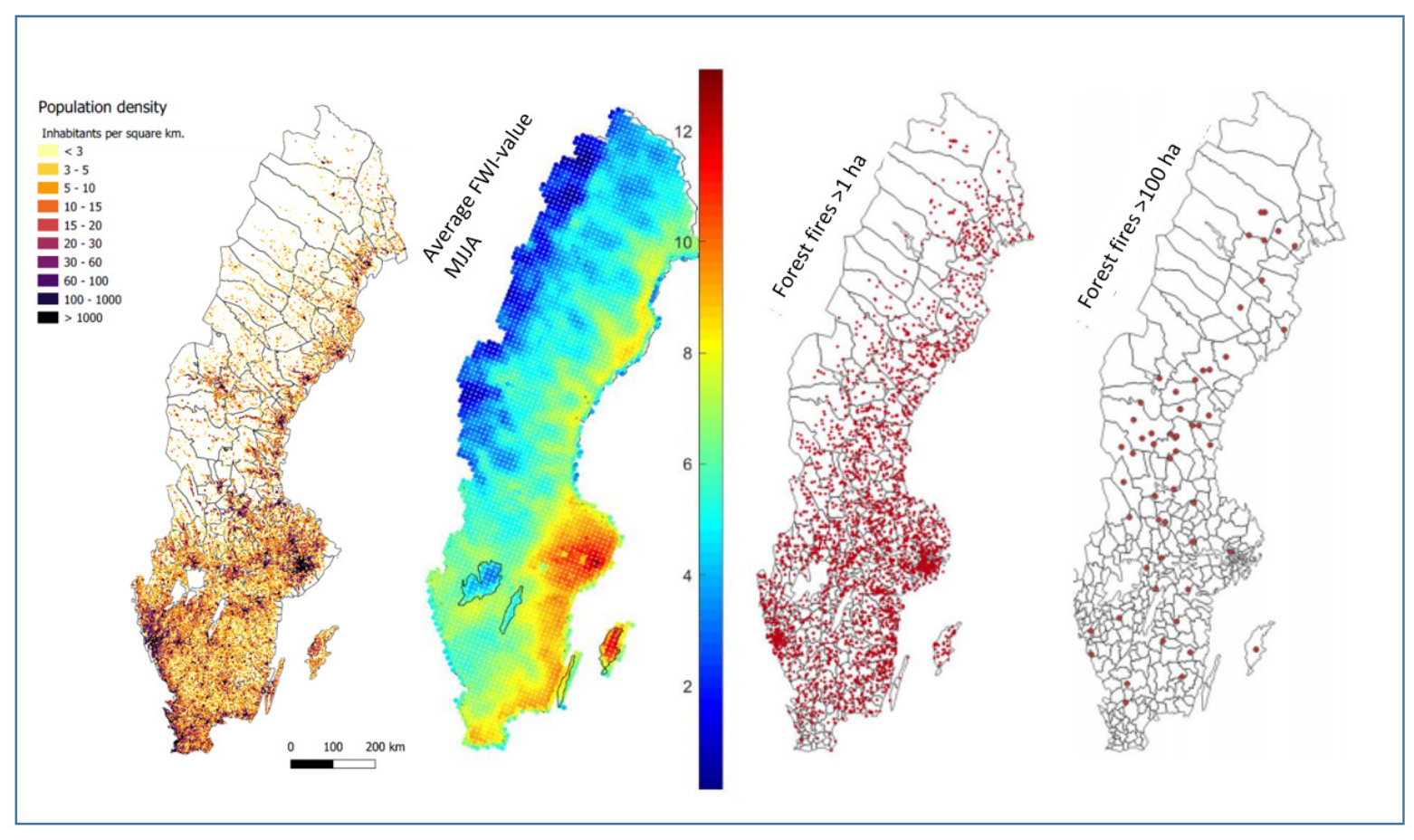

Figure 3.7. Determining factors for wildfires and fire distribution within Sweden from left to right: population density, fire weather (average May to August FWI [fire weather index] calculated from gridded weather data 1999-2018), forest fires $>0.5$ ha 1996-2018, and forest fires $>100$ ha. Adapted from Sjöström and Granström (2020).

The number of dispatches to suppress wildfires over the 23-year period 1996-2018 averaged nearly 5000 per year, of which about half were judged to have covered mainly forest terrain and the rest covering mainly 'treeless terrain'. Most of the latter would have been 'grass fires', i.e. early-season fires in grass-herb litter on abandoned fields, etc. The areas burnt averaged at 
3600 ha per year, of which $80 \%$ was on forested land (including clear-felled areas). There was a three-fold range in the number of fires between years over this period, but a 57 -fold variation in area burnt, which was dramatically influenced by events in 2014 and 2018.

The causes of forest fires were predominantly anthropogenic. On average only $8 \%$ of all forest fires were attributed to lightning, but this figure increases to $17 \%$ for fires larger than 10 ha. Likewise, in the top years, such as 2018, their impact was very high; 935 lightning-started fires were reported in 2018, accounting for 65\% of all area burnt. Ahlström et al. (2019) did an analysis to examine the accuracy of attribution to lightning in incident reporting, through a spatio-temporal matching of recorded lightning strikes to fire starts, for all fires larger than 0.5 ha. Agreement was generally good. Only $13 \%$ of those reported as lightning-caused could not be verified by strike data. Likewise, $7 \%$ of those reported as non-lightning (including cause unknown) matched well with strike data and were likely lightning ignited. Of all fires larger than 0.5 ha in this exceptional fire year, lightning accounted for between $28 \%$ and $33 \%$, depending on how conservative the spatial boundaries for accepting a match were set. Lightning ignitions show dramatic geographic gradients within Sweden, coupled with gradients in summer precipitation (Granström, 1993). The 1944-1975 data give a threefold variation in ignition density between the south-east and south-west, and fivefold variation between the south-east and inland northern Norrland. At the national scale these gradients are largely mirrored by the average summer precipitation deficit (average summer precipitation minus potential evaporation) (Granström, 1993).

Machine operations in the forest have caused some of the largest fires in the country, notably the 14000 ha Västmanland fire in 2014, the 1800 ha Bodträskfors fire in 2006 and the 800 ha Hassela fire in 2008. The average number of reported incidents due to forest machinery account for only around $2 \%$ of all forest fires, but the actual number of ignitions taking place are in fact much higher. Interviews with operators (Sjöström et al., 2019) revealed that most ignitions are observed directly by the machine operator who then manages to extinguish them using tools and water carried on the machine. Only around $10 \%$ escape and lead to a dispatch by the fire brigade and thus enter the official statistics. Most machine-caused ignitions start as smouldering in dry humus and are caused by sparks from steel hitting rock. The most dangerous operation is mechanical scarification and also forwarding, if steel tracks are used. In later years forest managers have made considerable efforts to reduce machine-caused ignitions, primarily by avoiding operating during periods with high fire risk, but this is costly and difficult to balance. The analysis of coupled fire weather and incident data suggest that $35 \%$ of machinecaused wildfires, and nearly all area burnt, would have been avoided simply by not operating when FWI is above 20 (Sjöström et al., 2019). But machine-ignited fires were not only tied to periods of high fire risk. There was also a strong spatial coupling to areas with a high proportion of large boulders, as indicated by NFI data, and thus the distribution within the country of machine-caused fires does not mirror the fire-climate gradients, as would otherwise be expected.

A troubling fact is that a large number of fires are caused by 're-ignition', which is a somewhat inaccurate term for fires that have been suppressed by the firefighters, handed over to the landowner for mop-up, but later have escaped and led to a new alarm call. These account for ca. $3 \%$ of all fires but out of all fires larger than 100 ha they account for $21 \%$, making it the single largest fire cause for this size category (Sjöström and Granström, 2020). There is often a combination of two different factors behind these events: the firefighters leaving the area too soon and inexperienced personnel doing the mop-up. Firefighters typically finish work on an ordinary, small forest fire in late evening and then turn it over to the mop-up crew sent by the 
forest owner. Often the firefighters retract most of their equipment (pumps, hoses), perhaps leaving a few water cans and a water-filled collapsible pool. In late evening it is easy to underestimate the risk potential for the next day when winds increase, temperature goes up and relative humidity down. If there is still active smouldering at the perimeter when winds pick up again in the morning, flaming fire is very likely to emerge and will lead to an escape, unless it is well tended by active mop-up. If conditions are severe, this often requires a hose-lay around the perimeter of the burnt area and enough people with fire experience on site.

All forest fires in 1996-2018 (43000 incidents) were matched with the weather and fire danger index for the date of ignition. The FWI distributions of the fires were progressively skewed towards higher values the larger their size (Fig. 3.8). For fires $>100$ ha, median FWI was 26 and nearly $80 \%$ of them had started on days with FWI $>20$, again showing FWI to be a good indicator of fire danger.

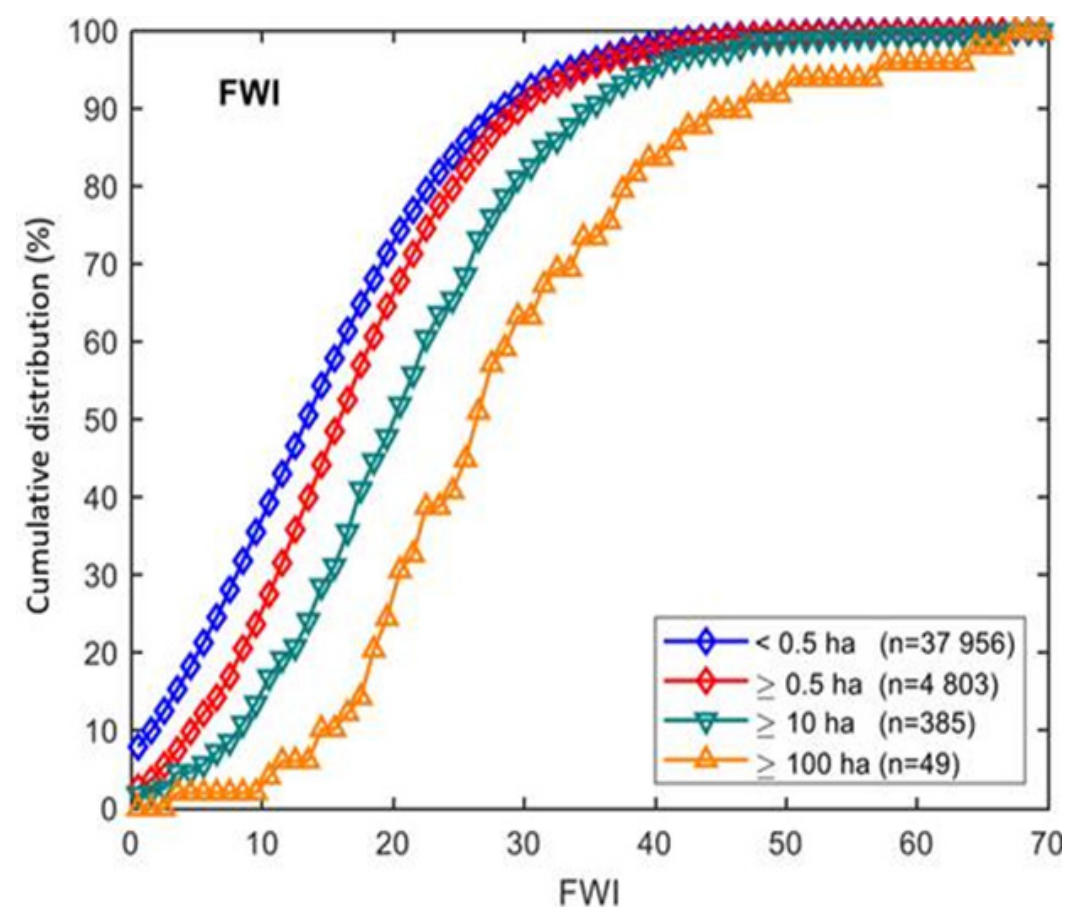

Figure 3.8. Cumulative distribution of forest fires in Sweden 1996-2018 of different size classes in relation to the local FWI value on the day of their ignition (Sjöström and Granström, 2020).

Within all regions, there was a linearly increasing daily probability of having a small forest fire $(<0.5 \mathrm{ha})$ with increasing FWI value, although the risk was around five times higher in the south-eastern part of the country than in the interior north (Fig. 3.9), which is a reflection of the much higher population density in the former part. However, the probability of having a fire larger than 10 ha has increased exponentially with increasing FWI value and was at similar levels for both these regions, likely due to the higher density of fire stations in the south leading to quicker access to fires and a smaller proportion of re-ignitions. 

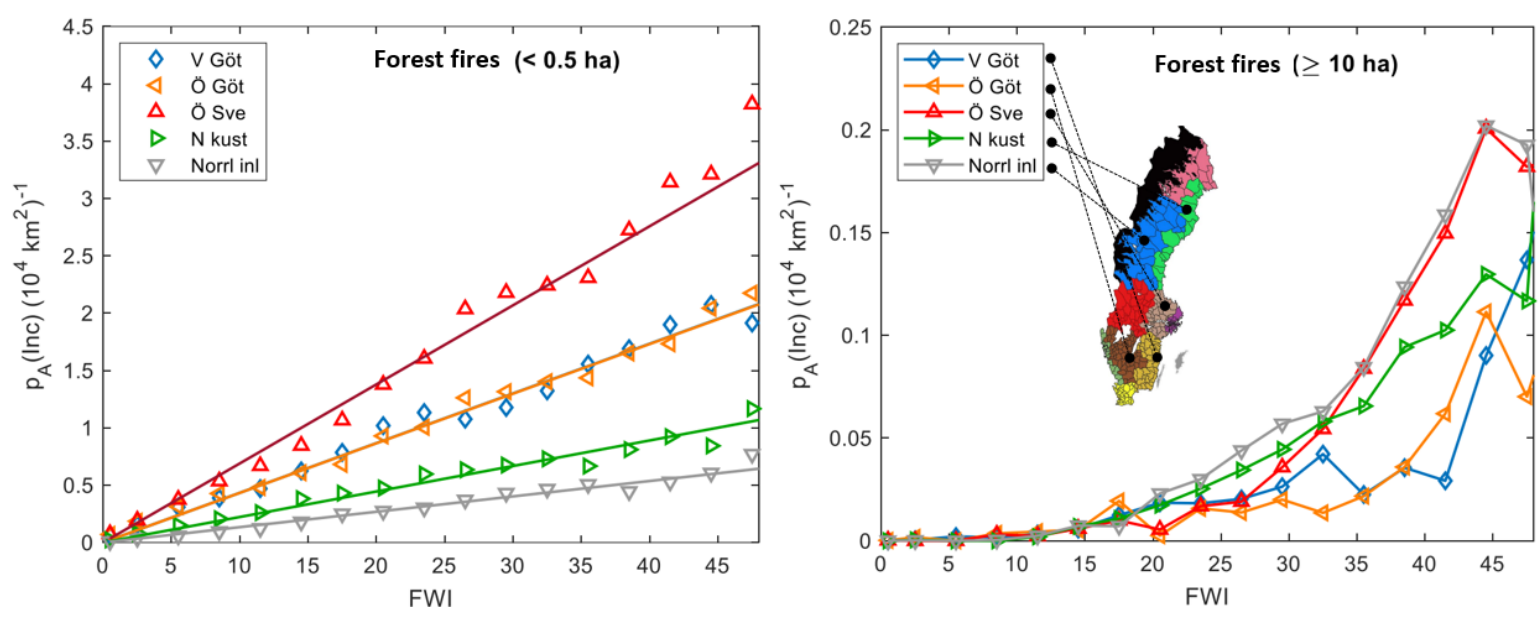

Figure 3.9. Left: Probability of having a small $(<0.5 \mathrm{ha})$ forest fire per day per $10000 \mathrm{~km}^{2}$ in relation to the FWI index within five regions in Sweden. Right: Probability of having a fire larger than 10 ha in relation to the FWI index. From Sjöström and Granström (2020).

\subsubsection{Fires that become large}

A few fire events accounts for a majority of area burnt and thus it is important to elucidate their characteristics and understand what actually caused them to grow large. In comparison with Finland (chapter 3.2) it is obvious that Sweden has had a higher number of relatively large fires. In the 1996-2018 statistics, 43 fires were larger than 100 ha and since the early 1990s several have been in the order of 1000 ha: Vakö myr (2000 ha), and Torsburgen (1500 ha) in 1992, Lit (1100 ha) in 1997, Bodträskfors (1800 ha) in 2006, Hassela (800 ha) in 2008 and Västmanland (14 000 ha) in 2014. Then in 2018, six fires were close to or above 1000 ha: (Enskogen (4330 ha), Ängra (3800), Trängslet (3470 ha), Fågelsjö (3920 ha) Storbrättan (940 ha and Nötberget (870 ha). In 2018 an additional six fires were larger than 200 ha. To find a similar array of large fires we have to go back to 1933 (Högbom, 1934), or possibly even further back in time.

Of the fires mentioned above, eight had initially been controlled to a very small size, but escaped due to insufficiently aggressive mop-up: Torsburgen, Bodträskfors, Hassela, Enskogen, Trängslet, Fågelsjö, Storbrättan and Nötberget. This would be the single most obvious factor. Further, most large fires, with the exception of Västmanland, occurred in sparsely populated parts of the country (Fig. 3.7), which likely influenced the resources brought in for the initial attack. Of course, they also happened during periods with extreme fire danger (Fig. 3.8). In all the above cases, there were shorter or longer episodes of crown fire in the head sections, making suppression impossible there and then. The most extreme case was in the afternoon of the fifth day of the Västmanland fire, where several heads along a 5-km-wide front made runs with an average rate of spread of around $80 \mathrm{~m} /$ minute over a three-hour period, advancing the front by nearly $15 \mathrm{~km}$ before nightfall. Spotting was very intense, with welldocumented spotting distances (filmed in IR from a surveillance plane) of up to $2 \mathrm{~km}$.

What then made these fires finally stop? The primary cause was that the weather changed for the better. Long continuous periods of severe fire weather are very rare in Sweden (Sjöström and Granström, 2020) and when fire danger drops, suppression can become effective. Some of the 2018 fires show how difficult firefighting becomes when a fire is already large, simply because of the length of the perimeter. Whereas some of the large fires that had started on 1214 of July received some rain around 19 July, the fires within the Ljusdal fire complex (Fig. 3.10) did not. Although scooping planes (brought in from southern Europe) and helicopters 
were continually attacking, they were not able to permanently secure the perimeter, which is easy to understand when considering that the length of the final perimeter was $192 \mathrm{~km}$ ! Aerial drops typically deliver $5 \mathrm{~mm}$ of water and in 1-2 days of good drying weather the surface fuels are again dry-enough to carry fire, which can easily emerge from smouldering deep in the humus layer, where the water from the aerial attack never reaches. Active mop-up with hoselays and pumps is also near impossible given the length of the perimeter, which largely lay in forest terrain, i.e. not along water or roads. Fire spread finally stopped when rain came on the 28 July, after 15 active fire days!

An alternative tactic would be to find suitable potential barriers ahead of the fire and perform burn-out operations, as would have been done in the past. In fact, there were seven attempts to do this during the 2018 fires, of which at least three were successful. None led to a worsened situation. They were all executed by people experienced in conducting prescribed fires (Granström, 2020).

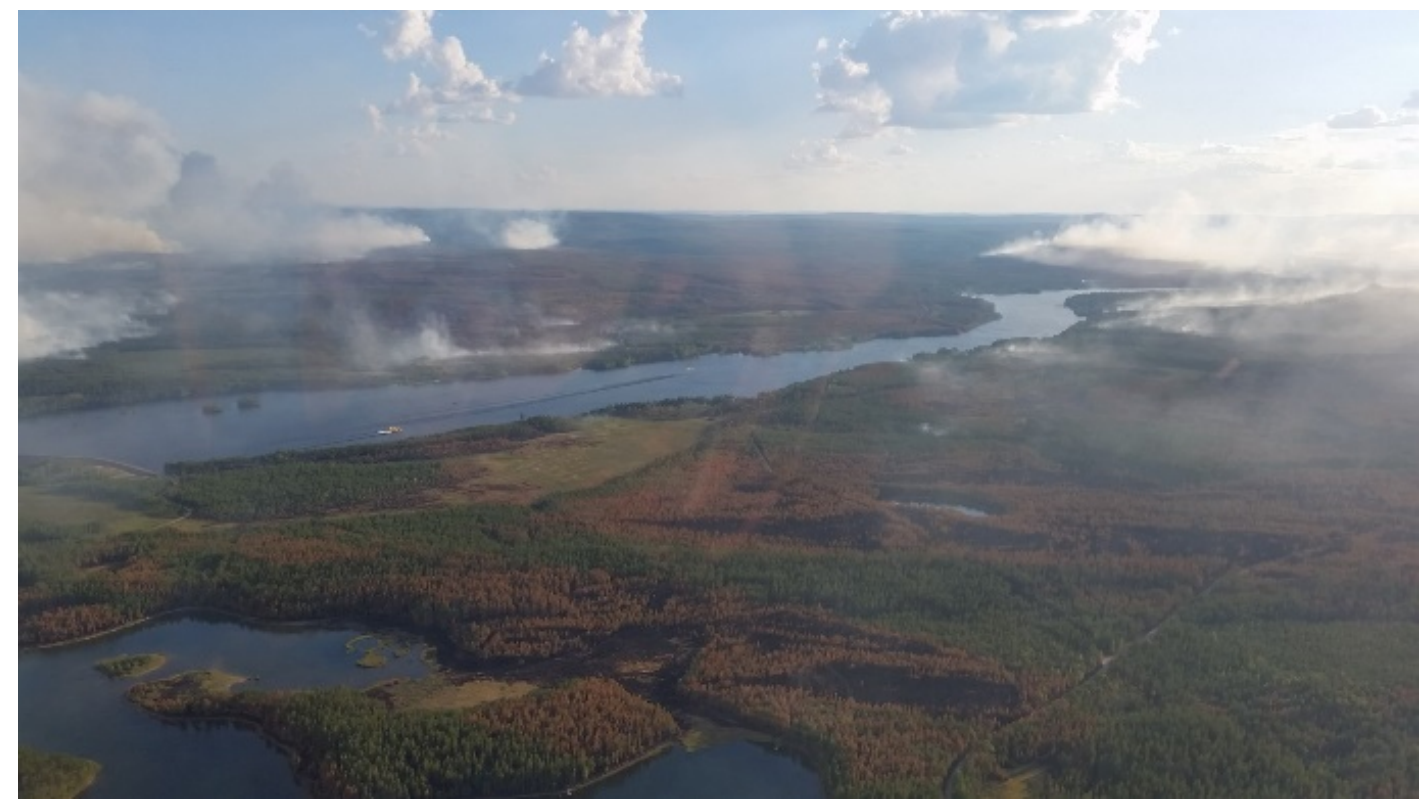

Figure 3.10. View over parts of the Ljusdal fire-complex on 25 July 2018. Four lightning ignitions on 14 July on both sides of the Ljusnan river finally grew to a combined area of 8995 ha and a combined perimeter of $192 \mathrm{~km}$ ! All terrain in the foreground of the photo had burnt days earlier, with intensity varying from crown fire to low-intensity surface fire. Suppression resources were initially weak but expanded gradually, including scooping planes from southern Europe (two CL-415s can be seen scooping from the river) and many helicopters. Despite this, and a ground crew of ca. 500 people, fire spread was not stopped along all of the perimeter until rain started on 28 July. Photo: Anders Granström.

\subsubsection{Trends into the future}

Climate will change, but what happens with fire weather is less than clear (Yang et al., 2015) and may differ between different parts of the country. An analysis of the number of high-danger days (FWI $>22$ ) per summer (Fig. 3.11) reveals no consistent trend over the last 68 years, which is similar to observations from Finland (chapter 3.1). Most people remember the summer of 2018 as exceptional, but from a 50-year perspective several summers have had similar or more high-danger days than 2018, although none of these have been in the last 20 years (Fig. 3.10). However, over this whole period there had not been nearly as large an area burnt in any year as 
in 2018 or 2014. The previous top year was 1959, with an equal or higher number of highdanger days as in 2018, an equal number of forest fires (7000, 572 of them from lightning), but only 9000 ha of forest land burnt, vs 25000 ha in 2018. In the late 1950s, forest road networks were not well developed, telecommunications poor, access to pumps and hoses poor and aerial firefighting non-existent. On the other hand, there were numerous manual forest workers and small-scale farmers in rural areas, who were experienced in handling fire. These made up the bulk of the suppression crews and were evidently quite successful. In case of bad situations, large numbers of conscripted military personnel were also deployed. This is a completely different picture to today.

What happens with wildfire over a slightly longer perspective depends on the delicate balance between fire load (number of ignitions, fire weather) and fire suppression. Whether the fire weather becomes more severe or not, societal changes in the countryside may be a more decisive factor. The continuing depopulation of rural areas is already making it difficult to recruit part-time firefighters, and this will only become more difficult in the coming decades. The solution with regard to wildfire suppression will likely be to improve rapid detection and employ aerial suppression in the initial attack, plus the organisation of high-quality mop-up crews by forest owners.
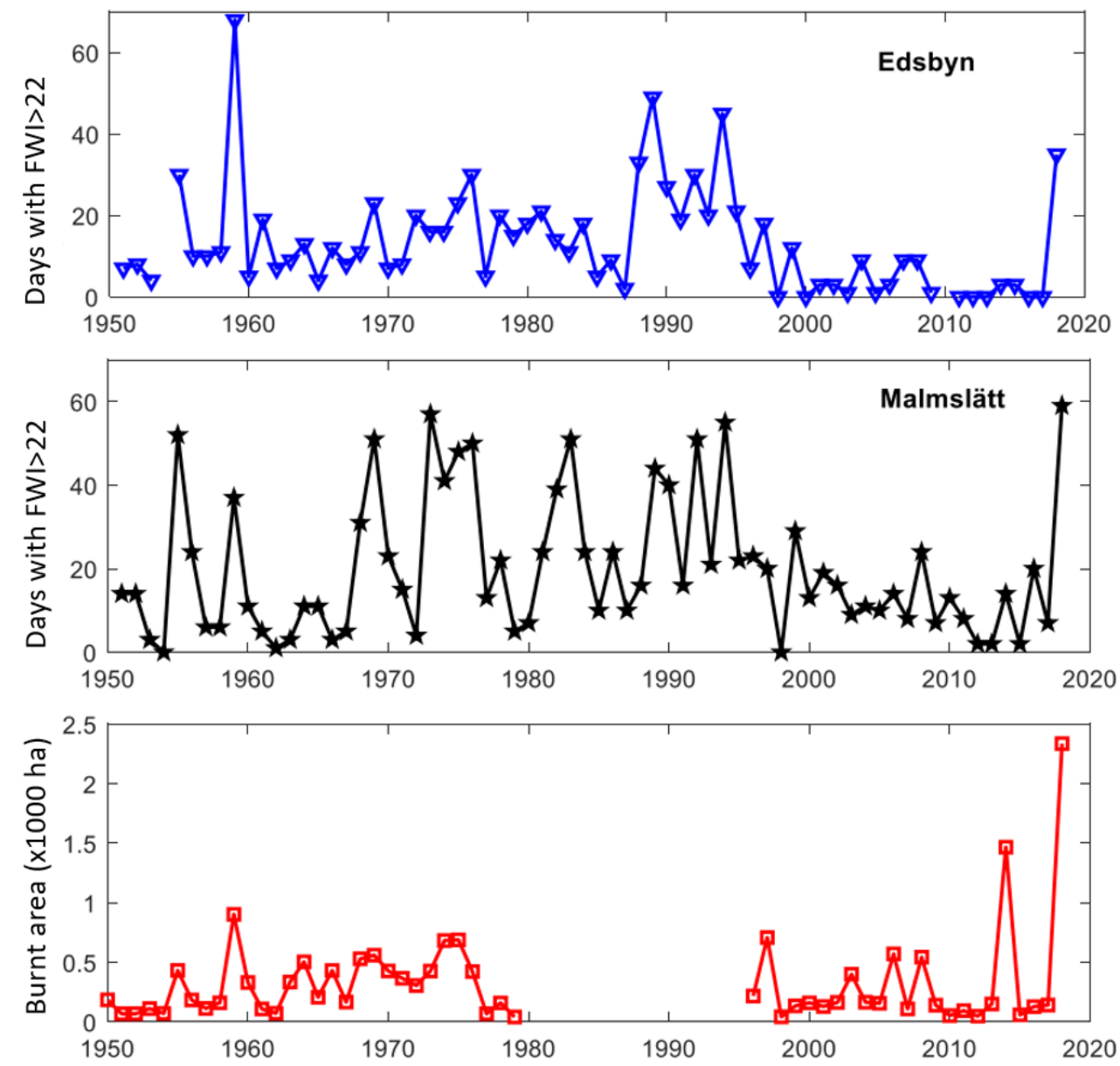

Figure 3.11. (Upper two panels) Number of days per year with FWI $>22$, based on daily weather observation data (April-September) from the two stations Edsbyn (central Sweden) and Malmslätt (south-east Sweden). The years 1954 and 2010 lack data for Edsbyn. (Lower panel) Total area burnt in forest fires. In the period 1980-1995 no statistics were collected for area burnt. From Sjöström and Granström (2020). 


\subsection{In the Republic of Karelia, large year-to-year variation in the number of fires exists, and the average size of one fire is many times higher than in other parts of Fennoscandia}

\subsubsection{Introduction}

In the Russian part of Fennoscandia, fire regimes have changed radically since the beginning of human activities in forests. Natural fire regimes specific to various types of geographic landscapes have been studied by Gromtsev $(1993 ; 1996)$. Nowadays, lightning is no longer the only cause of ignition and human-caused ignitions have become much more common.

In this chapter, the forest fire data for the whole of the Republic of Karelia available from 1956 to 2019 is presented. Since 1992, the data has also been available by district. Fire statistics were also analysed for the adjacent Murmansk, Arkhangelsk and Leningrad regions that belong entirely or partially to the physiographic region, called the Fennoscandian Shield (Gromtsev, 1993). Forest fire data for the Republic of Karelia has been published in the twenty-eight annual 'State Reports on the Environment in the Republic of Karelia', released since 1993 (State Report..., 2020 and the preceding yearbooks). In addition, various earlier (since 1956) reports by relevant ministries and departments were used. The data on the Murmansk, Arkhangelsk and Leningrad regions were derived from the official annual State Reports on the Environment covering the period from 1998 to 2019.

In the Russian Federation, the five classes of forest fire risk can be distinguished (Fig. 3.12; Table 3.2). 


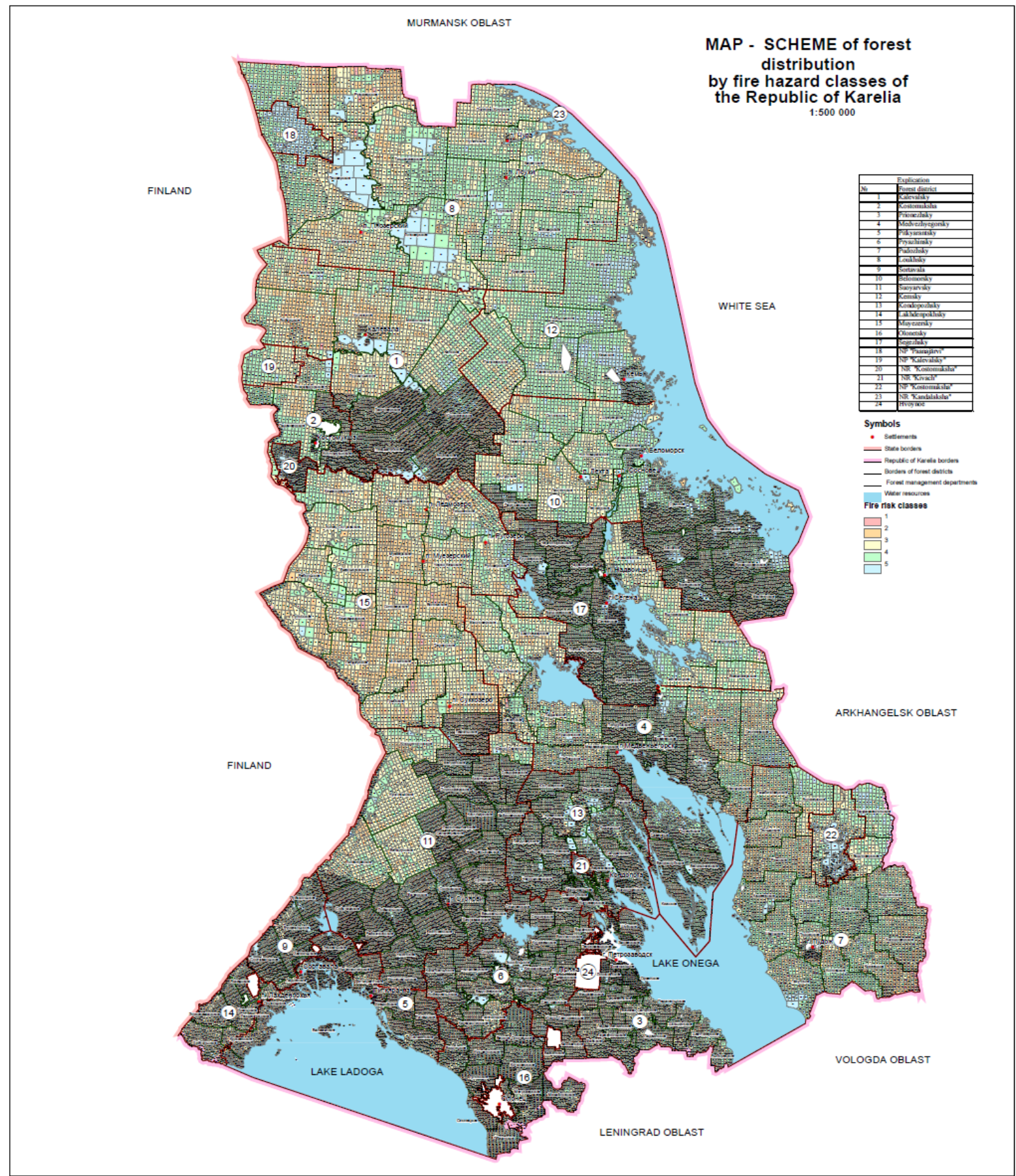

Figure 3.12. Forest fire risk classes in the Republic of Karelia. High-resolution version of the figure can be viewed online: https://en.ilmatieteenlaitos.fi/iba-forest-fires 
Table 3.2. Wildfire risk classes based on the fuel characteristics for the whole territory of the Russian Federation.

\begin{tabular}{|c|c|c|}
\hline $\begin{array}{l}\text { Wildfire risk } \\
\text { class }\end{array}$ & $\begin{array}{l}\text { Area characteristics (the types of forests, } \\
\text { harvested areas and open areas) }\end{array}$ & Fire regime \\
\hline Very high & $\begin{array}{l}\text { Pine lichen and pine heather forests (Pineta } \\
\text { cladinosa, P. hylocomiosa), according to the } \\
\text { Russian classification used in the forest } \\
\text { inventory (Pobedinsky et al, 1982, adapted). } \\
\text { Young conifer forests. Clear-cut areas with } \\
\text { understorey vegetation dominated by lichens, } \\
\text { Calluna sp., Calamagrostis sp. and other types } \\
\text { of clearcuttings on dry sites, especially with } \\
\text { logging slash. Disturbed, declining and } \\
\text { severely damaged forest stands with snags and } \\
\text { downed dead wood; windthrow areas. } \\
\text { Incompletely harvested areas, recently slightly } \\
\text { burnt areas with high fuel load. }\end{array}$ & $\begin{array}{l}\text { Surface fires are possible during the } \\
\text { entire fire season. In the areas covered by } \\
\text { a forest stand, crown fires can also occur. } \\
\text { Fire risk is especially high on heather and } \\
\text { other grassy types of harvested areas on } \\
\text { dry sites in spring, and in some areas in } \\
\text { autumn. }\end{array}$ \\
\hline $\begin{array}{l}\text { II } \\
\text { High }\end{array}$ & $\begin{array}{l}\text { Lingonberry pine forests (Pineta vacciniosa), } \\
\text { especially with dense pine undergrowth or } \\
\text { juniper bushes. Dwarf Siberian pine larch } \\
\text { forests (Lariceta pumilo-pinosa). }\end{array}$ & $\begin{array}{l}\text { Surface fires are possible throughout the } \\
\text { entire fire season. Crown fires occur } \\
\text { during the dry periods, when the number } \\
\text { of forest fires or size of burnt area } \\
\text { exceeds the long-term average values for } \\
\text { a given district. }\end{array}$ \\
\hline $\begin{array}{l}\text { III } \\
\text { Medium }\end{array}$ & $\begin{array}{l}\text { Oxalis and Vaccinium pine forests (Pineta } \\
\text { oxalidosa, P. myrtyllosa), lingonberry larch } \\
\text { forests (Lariceta vacciniosa), Siberian pine } \\
\text { forests (Pineta sibirica) of all types, except } \\
\text { herb-rich (herbosa) and Sphagnum } \\
\text { (sphagnosa) forest types, Vaccinium vitis- } \\
\text { idaea and Oxalis spruce forests (Piceeta } \\
\text { vacciniosa, P. oxalidosa). }\end{array}$ & $\begin{array}{l}\text { Surface and crown fires are possible } \\
\text { during the summer and, in Siberian pine } \\
\text { forests, also during the spring and } \\
\text { especially in the autumn. }\end{array}$ \\
\hline $\begin{array}{l}\text { IV } \\
\text { Low }\end{array}$ & $\begin{array}{l}\text { Filipendula and Polytrichum types of } \\
\text { harvested areas, especially with logging slash. } \\
\text { Pine forests, larch forests and deciduous forests } \\
\text { of herb-rich forest types. Mixed pine and } \\
\text { spruce forests with broadleaved trees; linden } \\
\text { (Tilia), hazel (Corylus), oak (Quercus), } \\
\text { (Piceeta and Pineta nemorosa), and blueberry- } \\
\text { type spruce forests (Piceeta myrtillosa), } \\
\text { Sphagnum and Polytrichum pine forests } \\
\text { (Pineta sphagnosa, P. polytrichosa), } \\
\text { Sphagnum Siberian pine forests (Pineta } \\
\text { sibirica sphagnosa), Vacciniun vitis-idaea, } \\
\text { Oxalis, Vaccinium and Sphagnum birch forests } \\
\text { (Betuleta oxalidosa, B. myrtillosa, B. } \\
\text { sphagnosa), Oxalis and Vaccinium aspen } \\
\text { forests (Tremuleta oxalidosa, T. myrtillosa). }\end{array}$ & $\begin{array}{l}\text { The emergence of fires (primarily surface } \\
\text { fires) is possible in herb-rich forest types } \\
\text { and on the Filipendula clearcuttings } \\
\text { during the periods of spring and autumn } \\
\text { fire peaks; in other types of forests and on } \\
\text { the Polytrichum clearcuttings, during } \\
\text { periods of summer peaks. }\end{array}$ \\
\hline V Absent & $\begin{array}{l}\text { Spruce, birch and aspen forests Polytrichum } \\
\text { and Sphagnum forests (Pineta, Betuleta and } \\
\text { Tremuleta polytrichosa and sphagnosa). Alder } \\
\text { forests (Alneta) of all types. }\end{array}$ & $\begin{array}{l}\text { A fire is possible only under particularly } \\
\text { unfavourable conditions, e.g. under long } \\
\text { drought periods. }\end{array}$ \\
\hline
\end{tabular}


Additionally, risk of fire ignition and spread is assessed according to weather conditions (Table 3.3). To assess the fire hazard depending on weather, a complex fire risk index has been introduced (see also 5.1.1). This index is calculated daily during the fire risk period (from the second half of April until the first half of September) on the basis of meteorological data. The wildfire risk index in forests depending on weather conditions is calculated as the sum of the product of the current air temperature $\left(\mathrm{t},{ }^{\circ} \mathrm{C}\right)$ and the difference between the current air temperature and the dew point during $\mathrm{N}$ days without rain (starting from the first day of more than $3 \mathrm{~mm}$ of precipitation in the afternoon of a rainless period). This index can range from one to several thousand degrees, and during periods of dry and hot weather, its value can exceed 10 000 degrees. In the territory of the Russian Federation, there are federal and regional classes of fire risks in forests according to weather conditions. At the federal level, the five classes of forest fire risk depending on weather conditions are distinguished (Table 3.3.).

Table 3.3. Wildfire risk classes based on weather characteristics for the territory of the Russian Federation.

\begin{tabular}{|l|l|l|}
\hline Fire risk class & The value of fire risk index $\left.\mathbf{~}^{\circ} \mathbf{C}\right)$ & Level of fire risk \\
\hline I & $0-300$ & Very low \\
\hline II & $301-1000$ & Low \\
\hline III & $1001-4000$ & Medium \\
\hline IV & $4001-10000$ & High \\
\hline V & $>10000$ & Very high \\
\hline
\end{tabular}

\subsubsection{Large inter-annual variability in fires across the Republic of Karelia}

In the Republic of Karelia, the average fire risk class in forests is 3.3. Forests in class 1 occupy 17\% (Fig. 3.12). Almost all fires are forest fires; the rest appear to be household and technogenic (ignited in factories, etc.) fires (State, 2019). The majority of forest fires $(61 \%)$ are human caused (3\% of fires are ignited from railways or highways, $1 \%$ from power transmission lines, $27 \%$ from agricultural land) and $8 \%$ from lightning. Statistical data on wildfires in the period 1956-2019 is presented in Figure 3.13. 


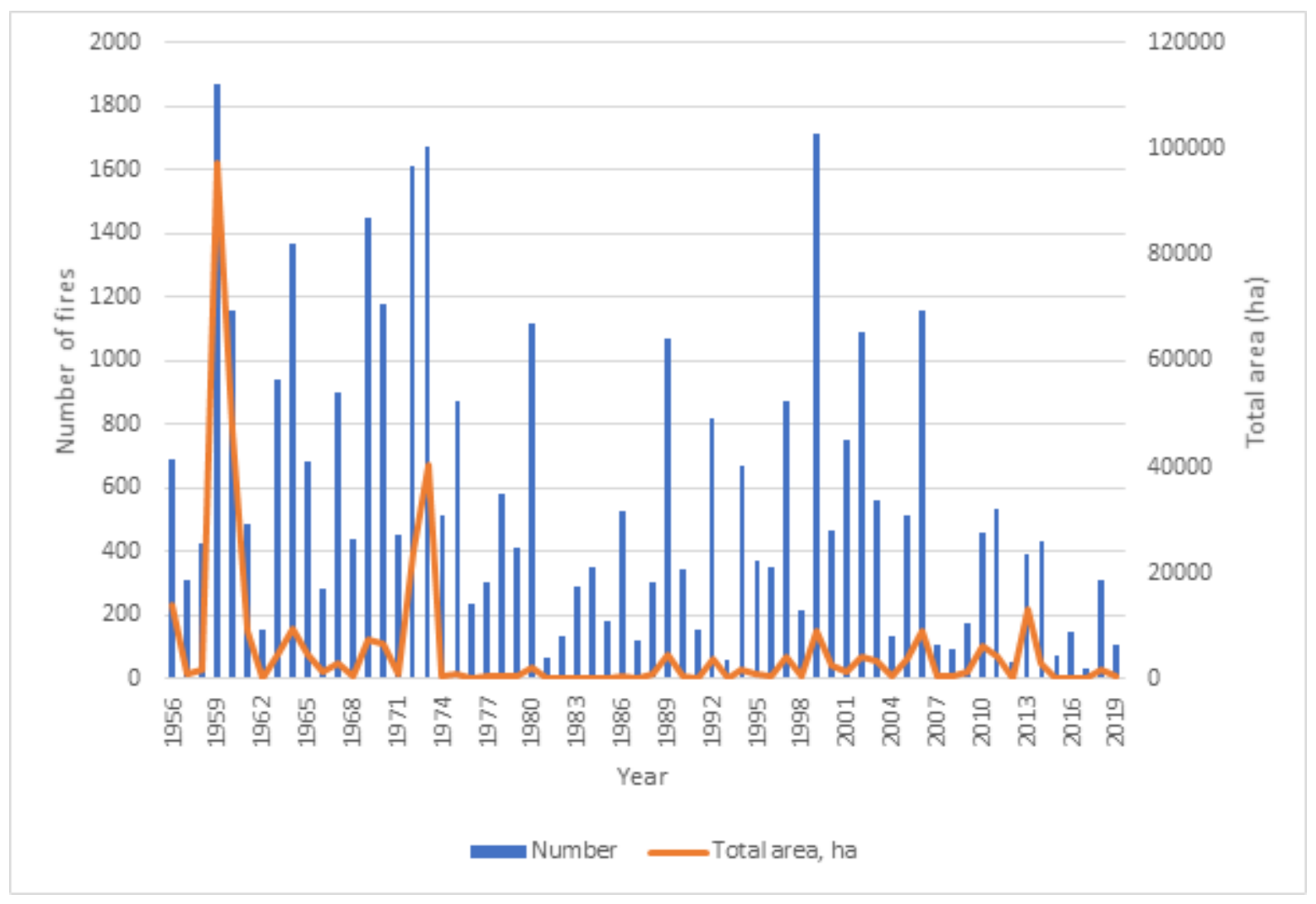

Figure 3.13. Number of fires and total area burnt in the Republic of Karelia 1956-2019.

The annual number of forest fires has varied over an exceptionally wide range since 1956, from 35 to 1872 . Total annual burnt area has varied from 35 to 97233 ha, and the annual average fire size from 0.5 to 76.4 ha. The total number of fires over the 64 years of observation has been 38559 (568 per year on average) with the total area burnt being 363503 ha, and an average annual burnt area of ca. 10 ha.

There were 13 fire seasons during the period from 1956 to 2019, in which the number of fires exceeded 1000, and four such seasons occurred between 1969 and 1973. In total, there were six seasons when the total wildfire area exceeded 10000 ha. In 1959 and 1960, the number of forest fires was as high as 1872 and 1156, respectively, and the total burnt area was 97223 and 46840 ha, with the average size being 76.4 and 40.5 ha, respectively. It could be noted that in Finland the largest big fire in the $20^{\text {th }}$ century was the Tuntsa fire in 1960 . This fire ignited in Russia and spread to Finland, and burnt a total of 120000 ha, of which 20000 ha in Finland. The large area burnt in 1959 and 1960 was obviously due to abnormal weather conditions very hot weather with very little rainfall. Even in relatively fire-resistant forest landscapes (fire risk very low to low) with the predominance of spruce habitats, fire covered vast areas, primarily due to spreading from grass-overgrown clear-cut sites. The fires were aligned mainly along timber haulage pathways. In the $1950 \mathrm{~s}$ and $60 \mathrm{~s}$, there appeared to be mostly narrow-track railroads with steam-driven trains. The sources of ignitions were flakes of fire from steam locomotives.

There is a high annual variation in the fire statistics data, partly because of improvements in the fire detection and control system in recent decades. In fact, there was only one year (2013) since 1973 in which the total area burnt in forest fires amounted to 13000 ha, and the average fire size was nearly 33 ha due to an abnormally dry summer. By then, the year was the top third 
in a series of warmest years over the 67 years of instrumental weather monitoring. As reported by meteorologists, early snowmelt caused the fire season to begin earlier (Gromtsev, pers. com). Eventually, the majority of administrative districts experienced a fire risk index of class III, and sometimes even IV. The weather at the beginning of June was dry and hot, with daytime air warming up to $+24 \ldots+28^{\circ} \mathrm{C}$, and on some days up to $+29 \ldots+33{ }^{\circ} \mathrm{C}$. Therefore, the weather further increased fire risk in the forests, and the prevalent fire risk class in most of the territory was II--III, but some districts even reached the highest class V. The regional Ministry of Emergency Situations classified five large fires as 'natural disasters'. The fires destroyed a total of 8600 ha of forest.

Since 1992, the statistical data on wildfires has been available for all administrative districts of the Republic of Karelia. This largely permits linking the number, total and mean annual burnt area to the forest landscape characteristics, which define how fire-susceptible a landscape is. For example, two middle-taiga districts with the most contrasting parameters: a) Pudozhsky in the east of the region, between Lake Onego and the border with the Arkhangelsk Region (1.27 million ha); and b) Suojarvsky - east of the Russian-Finnish border (1.37 million ha, Table. 3.4) can be compared. 
Table 3.4. Forest fire statistics in the Pudozhsky (spruce-dominated landscapes) and Suoyarvsky (pine dominated landscapes) districts in the Republic of Karelia over the period 1992-2019.

\begin{tabular}{|c|c|c|c|c|c|c|}
\hline \multirow[t]{2}{*}{ Year } & \multicolumn{3}{|c|}{ Pudozhsky district } & \multicolumn{3}{|c|}{ Suoyarvsky district } \\
\hline & $\begin{array}{l}\text { Number } \\
\text { of fires }\end{array}$ & $\begin{array}{l}\text { Total } \\
\text { burnt } \\
\text { area, ha }\end{array}$ & $\begin{array}{l}\text { Average burnt } \\
\text { area in a single fire, } \\
\text { ha }\end{array}$ & $\begin{array}{l}\text { Number } \\
\text { of fires }\end{array}$ & $\begin{array}{l}\text { Total burnt } \\
\text { area, ha }\end{array}$ & $\begin{array}{l}\text { Average burnt area } \\
\text { in a single fire, ha }\end{array}$ \\
\hline 1992 & 36 & 119 & 3.3 & 74 & 565 & 7.6 \\
\hline 1993 & 9 & 38 & 4.2 & 6 & 6 & 1.0 \\
\hline 1994 & 26 & 20 & 0.8 & 31 & 37 & 1.2 \\
\hline 1995 & 22 & 72 & 3.3 & 39 & 39 & 1.0 \\
\hline 1996 & 10 & 13 & 1.3 & 27 & 106 & 3.9 \\
\hline 1997 & 53 & 670 & 12.6 & 74 & 1097 & 14.8 \\
\hline 1998 & 8 & 17 & 2.1 & 8 & 34 & 9.2 \\
\hline 1999 & 85 & 553 & 6.5 & 170 & 574 & 3.4 \\
\hline 2000 & 8 & 8 & 1.0 & 3 & 56 & 18.7 \\
\hline 2001 & 28 & 33 & 1.2 & 70 & 221 & 3.2 \\
\hline 2002 & 23 & 38 & 1.7 & 119 & 1400 & 11.8 \\
\hline 2003 & 12 & 10 & 0.8 & 61 & 53 & 0.9 \\
\hline 2004 & 5 & 16 & 3.2 & $2^{*}$ & $0^{*}$ & $0^{*}$ \\
\hline 2005 & 29 & 95 & 3.3 & 36 & 477 & 13.2 \\
\hline 2006 & 45 & 161 & 3.6 & 138 & 947 & 6.9 \\
\hline 2007 & 2 & 2.5 & 1.2 & 6 & 62 & 10.3 \\
\hline 2008 & 4 & 1 & 0.2 & 2 & 0.6 & 0.3 \\
\hline 2009 & 2 & 0.7 & 0.4 & 16 & 33 & 2.1 \\
\hline 2010 & 16 & 148 & 9.2 & 32 & 274 & 8.6 \\
\hline 2011 & 65 & 1224 & 18.8 & 42 & 96 & 2.3 \\
\hline 2012 & 2 & 0.4 & 0.2 & 2 & 1.5 & 0.7 \\
\hline 2013 & 23 & 322 & 14 & 21 & 131 & 6.2 \\
\hline 2014 & 17 & 38 & 2.2 & 69 & 946 & 13.7 \\
\hline 2015 & 0 & 0 & 0 & 4 & 8.3 & 2 \\
\hline 2016 & 4 & 2.8 & 0.7 & 4 & 8.1 & 2 \\
\hline
\end{tabular}




\begin{tabular}{|l|l|l|l|l|l|l|}
\hline 2017 & 0 & 0 & 0 & 1 & 1 & 1 \\
\hline 2018 & 2 & 3.8 & 2 & 19 & 101 & 5.3 \\
\hline 2019 & 2 & 12.4 & 6.2 & 11 & 26 & 2.4 \\
\hline $\begin{array}{l}\text { Variati } \\
\text { on }\end{array}$ & $0-85$ & $0-1224$ & $0-18.8$ & $1-170$ & $1-1400$ & $0-18.7$ \\
\hline $\begin{array}{l}\text { Total } \\
\text { average }\end{array}$ & $538 / 19^{1}$ & $3619 / 129^{2}$ & $6.3^{3} / 3.7^{4}$ & $1087 / 39^{1}$ & $7301 / 261^{2}$ & $6.7^{3} / 5.5^{4}$ \\
\hline
\end{tabular}

* small area ignitions. ${ }^{1}$ averaged over the entire period (total number of fires/ 28 years). ${ }^{2}$ averaged over the entire period (total area of fires $/ 28$ years). ${ }^{3}$ averaged over the entire period (total area of fires / total number of fires over 28 years). ${ }^{4}$ average annual (sum of average areas per year for 28 years).

At least two-thirds of the Pudozhsky district area is characterised as moderately paludified landscapes with a high variety of landforms and bedrock, but with the prevalence of spruce habitats (spruce forests prior to logging, and spruce-deciduous and deciduous forests after logging). In the Suojarvsky district, at least two-thirds of the area is covered by moderately and heavily paludified forests with various landforms, and a dominance of pine habitats (pine forests both before and after logging). The distribution of forest types defines the conditions for fire spread and intensity. The spruce-dominated landscapes of Pudozhsky district include relatively fire-resistant bilberry-, moist bilberry-, herb-sphagnum-, and horsetail-sphagnumtype forest stands. After logging, fairly fire-resistant mixed deciduous and spruce-deciduous forests have developed. Exceptions are: 1) harvested areas with the ground vegetation dominated by grasses, 2) young stands before canopy closure in spring, and only before the growing season begins. The dominant forest types in the Suojarvsky pine landscapes are lichen, lingonberry and bilberry pine stands, which are highly susceptible to fire. The landscapes are dominated by young and middle-aged pine stands with thin bark and tree crowns low above the ground on mineral soil. If ignitions happen, the fire in such stands would usually be lowintensity surface fires, causing only partial damage to the stand (Gromtsev, 2002).

The fire statistics in the Pudozhsky and Suojarvsky districts show the differences in the total number of fires and the annual average (over the entire period), as well as the total burnt area averaged across and within years. The exceptions were the similar mean annual fire size averaged over the entire period (6.3-6.7 ha), and the abnormally large area affected by a large fire in Pudozhsky district in 2011 (1224 ha), while over the 21 years of observation it did not exceed 100 ha (usually much less than 50). For that exceptional year of 2011, meteorologists reported an elevated temperature background, uneven distribution of precipitation across the territory, and high thunderstorm activity in July. These factors raised the fire risk class in Karelian forests. In this situation, an emergency-level class I fire risk was announced in the Pudozhsky district in the first five days of August.

The landscape features in most of the Suojarvsky district are very different when compared to the other parts of the region, making it relatively unsusceptible to wildfires: spruce-deciduous and deciduous forests on glaciolacustrine plains with loamy sand to loamy soils, which are relatively fire resistant. On the other hand, a large part of the Pudozhsky district is highly susceptible to fire. Such are pine forest areas with loamy sand to sandy soils in an aquaglacial landscape. Speaking of 2011, it is obvious that the rapid rise in the total fire area in the 
Pudozhsky district was, generally, due to large fires in these types of forests, as well as in loamy sand to sandy localities within spruce landscapes. If these sites are excluded from analysis, differences between pine and spruce landscape stands in terms of the number, total area and average size of modern wildfires would be at least 3-4 times greater. We conclude that the means of preventing, detecting and extinguishing fires should be concentrated in certain areas, and not distributed evenly throughout the region.

\subsubsection{High annual variation in fire statistics in the Arkhangelsk, Leningrad and Murmansk regions}

Statistical data on the number, total area and average size of forest fires are presented for the neighbouring administrative districts in the Murmansk, Arkhangelsk and Leningrad regions. Although the temporal coverage of the data hardly can be compared to the Republic of Karelia, it does provide an idea of the current forest fire situation with forest fires over the past 15 years (Table 3.6). Here, we report the main findings:

1. The number of fires and burnt area vary substantially over the years within the regions. The number and area of fires per year in the Arkhangelsk region ranged from 32 to 703, and from 120 to 80000 ha, respectively. The corresponding values for the Murmansk region were, respectively, 18-363 and 78-13 400, and for the Leningrad region 65-2888 and 18-12 237. Comparisons between the regions on these parameters would be irrelevant, considering the very different State Forest Fund area (5.68 to 27.12 million ha, Table. 3.5).

Table 3.5. Annual forest fire statistics by region.

\begin{tabular}{|l|l|l|l|}
\hline Year & $\begin{array}{l}\text { Number of } \\
\text { fires }\end{array}$ & $\begin{array}{l}\text { Total burnt area, } \\
\text { ha }\end{array}$ & $\begin{array}{l}\text { Average burnt } \\
\text { area } \\
\text { in a single fire, ha }\end{array}$ \\
\hline \multicolumn{4}{|l|}{ Murmansk region State forest fund - 9455.4 thousand ha } \\
\hline 2000 & 201 & 1244.3 & 6.2 \\
\hline 2002 & 290 & 2140.0 & 6.8 \\
\hline 2003 & 363 & 3525.3 & 9.7 \\
\hline 2004 & 171 & 1468 & 8.5 \\
\hline 2006 & 207 & 2823.8 & 13.6 \\
\hline 2007 & 38 & 235.8 & 6.2 \\
\hline 2008 & 29 & 77.8 & 2.3 \\
\hline 2009 & 59 & 515.7 & 8.7 \\
\hline 2011 & 86 & 523.5 & 6.1 \\
\hline 2012 & 67 & 422.6 & 6.3 \\
\hline 2013 & 214 & 1920.8 & 9.0 \\
\hline 2015 & 18 & 155.0 & 8.6 \\
\hline
\end{tabular}




\begin{tabular}{|c|c|c|c|}
\hline 2016 & 39 & 323.5 & 8.3 \\
\hline 2017 & 20 & 348.2 & 17.4 \\
\hline 2018 & 178 & 13397.0 & 75.3 \\
\hline 2019 & 28 & 104.5 & 3.7 \\
\hline Range of variation & $18-363$ & $77.8-13397.0$ & $2.3-75.3$ \\
\hline $\begin{array}{l}\text { Total/average over the } \\
\text { period (16 years) }\end{array}$ & $2008 / 125.5$ & 29225.8 & 14.6 \\
\hline \multicolumn{4}{|c|}{ Arkhangelsk region State forest fund -27119.7 thousand ha } \\
\hline 2004 & 389 & 8132.3 & 20.9 \\
\hline 2005 & 314 & 2535.0 & 8.1 \\
\hline 2006 & 443 & 4889.5 & 11.0 \\
\hline 2007 & 54 & 1059.1 & 19.6 \\
\hline 2008 & 32 & 120.0 & 3.7 \\
\hline 2009 & 72 & 180.0 & 2.5 \\
\hline 2010 & 356 & 14210.0 & 40.0 \\
\hline 2011 & 703 & 79615.0 & 113.3 \\
\hline 2012 & 74 & 605.7 & 8.2 \\
\hline 2013 & 317 & 5341.4 & 16.8 \\
\hline 2014 & 119 & 562.9 & 4.7 \\
\hline 2015 & 56 & 539.3 & 9.6 \\
\hline 2016 & 112 & 480.3 & 4.3 \\
\hline 2017 & 34 & 851.3 & 25.0 \\
\hline 2018 & 123 & 909.3 & 7.4 \\
\hline Range of variation & $32-703$ & $120.0-79615.0$ & $2.5-113.3$ \\
\hline $\begin{array}{l}\text { Total/average over the } \\
\text { period ( } 15 \text { years) }\end{array}$ & $3198 / 213.2$ & $120028.1 / 801.9$ & 37.5 \\
\hline \multicolumn{4}{|c|}{ Leningrad region State forest fund -5679.6 thousand ha } \\
\hline 2006 & 2888 & 12237 & 4.2 \\
\hline 2007 & 307 & 668 & 2.2 \\
\hline 2008 & 504 & 1315 & 2.6 \\
\hline 2009 & 237 & 281 & 1.2 \\
\hline 2010 & 256 & 266 & 1.0 \\
\hline
\end{tabular}




\begin{tabular}{|l|l|l|l|}
\hline 2011 & 206 & 113 & 0.5 \\
\hline 2012 & 65 & 28.2 & 0.4 \\
\hline 2013 & 143 & 103.5 & 0.7 \\
\hline 2014 & 504 & 594.8 & 1.2 \\
\hline 2016 & 167 & 57.8 & 0.3 \\
\hline 2017 & 74 & 17.6 & 0.2 \\
\hline 2018 & 156 & 117.5 & 0.8 \\
\hline 2019 & 282 & 66.9 & 0.2 \\
\hline Range of variation & $65-2888$ & $17.6-12237$ & $0.2-4.2$ \\
\hline $\begin{array}{l}\text { Total/average over the } \\
\text { period 2006-2019 (13 } \\
\text { years) }\end{array}$ & $5789 / 445.3$ & $15865.9 / 1220.4$ & 2.7 \\
\hline
\end{tabular}

2. Overall, there is an obvious asynchrony in years with extreme values in the regions characterised above. Thus, burnt areas in the Murmansk, Arkhangelsk and Leningrad regions were greatest in 2018, 2011 and 2006, respectively, and the greatest number of fires were recorded in 2003, 2011 and 2006, respectively. The only plausible explanation is the differences in the weather conditions during the fire season between the regions in the west of the Russian boreal zone. For example, the peak in fire activity in the Arkhangelsk region in 2011 was due to the weather conditions that were highly conducive to fire emergence and spread (no rainfall coupled with high air temperature). The mean annual air temperature was $20^{\circ} \mathrm{C}$ above normal. The rainfall in June was below normal throughout the region. Furthermore, July precipitation was $40-50 \%$ below normal.

3. No trends are evident for either an increase or a decrease in the number and area of wildfires (taking into account data for the 64-year period in the Republic of Karelia).

4. There is no clear correlation between the number of fires and the total burnt area. For example, in 2003 the forests in the Murmansk region experienced 363 wildfires (record-high value), which totalled 3525 ha in area. On the other hand, the number of fires in 2018 was more than half that (178), but the total area burnt was the greatest ever (almost 14000 ha). Obviously, the reason was large fires whose propagation was not confined in the early stages.

\subsubsection{Russian fire statistics do not include all forest fires}

The fire statistics for Russian part of Fennoscandia should be interpreted with caution. Some large sources of uncertainties in the estimates of the number of fires and burnt area are listed below.

1. The official data on the number of forest fires and burnt areas have only been reported for such areas of the forest fund (or 'forest estate', comprising the lands that are covered or may be potentially covered with forest vegetation and are managed for forestry purposes), where some kind of fire suppression is practised (Shvidenko and Goldammer, 2001). In the so-called 'control zones', no forest fire suppression is practised. In north-western Russia, such zones are 
found in the Arkhangelsk region and the Komi Republic (https://aviales.ru/default.aspx?textpage=229).

2. The forest fire statistics often underestimate burnt areas, especially for areas not covered by forest (Shvidenko and Goldammer, 2001).

3. The official statistical data on forest fires before 1988 were deliberately falsified for political reasons (Shvidenko and Goldammer, 2001).

4. The system of space monitoring of large forest fires was only created in 2004 (Information System for the Remote Monitoring of Forest Fires of the Federal Forestry Agency - ISDMRosleskhoz). However, even since 2004 forest fire statistics have not been complete, since the ISDM-Rosleskhoz represents a system for monitoring only large forest fires.

5. Former agricultural lands that are currently covered in forest are not officially included in the state forest fund. Fires ignited on these lands are not classified as forest fires. Here are some examples of discrepancies in figures for 2020, i.e. the most trustworthy data for the whole period of consideration. In the Republic of Karelia, according to the ISDM-Rosleskhoz data (https://pushkino.aviales.ru/main pages/about.shtml), the number of fires is 57, the total burnt area is 657 ha, of which 521 ha are on forest land. Abandoned agricultural lands amount to 307 000 ha, which accounts for $2 \%$ of the area of the republic. According to the data of satellite monitoring of wildland fires outside the state forest fund (https://maps.greenpeace.org/maps/spring fires 2020/), i.e. mainly on forested abandoned agricultural lands, the total burnt area in the Republic of Karelia comprised 736 ha.

\section{References}

Aakala, T. 2018. Forest fire histories and tree age structuries in Värriö and Maltio Strict Nature Reserves, northern Finland. Boreal Environment Research 23: 209-219.

Agee, J.K., Skinner, C. 2005. Basic principles of forest fuel reduction treatments. Forest Ecology and Management 211: 83-96.

Ahlström, M., Backlund, A., Bergstrand, M., Flodin, E., Lundström, C., Wigertz, F., Ölwing, T. 2019. Analys av blixtnedslag som antändningskälla för skogsbränder sommaren 2018 [Analysis of lightning strikes as ignition source for forest fires in summer of 2018]. Uppsala University. 208 pp.

Anonymous 1960. Reviderad brandlagstiftning. Betänkande avgivet av 1954 års brandlagsrevision. Statens offentliga utredningar 1960: 34.

Blomqvist, A.G. 1888. Kulowalkeasta. Simeliuksen perillisten osakeyhtiön kirjapaino, Helsinki. 15 pp. [Of forest fire [In Finnish].]

Clear, J., Molinari, C., Bradshaw, R. 2014. Holocene fire in Fennoscandia and Denmark. International Journal of Wildland Fire 23: 781-789.

Drobyshev, I., Niklasson, M., Linderholm, H.W. 2012. Forest fire activity in Sweden: Climatic controls and geographical patterns in 20th century. Agricultural and Forest Meteorology 154: $174-186$.

Drobyshev, I., Granström, A., Linderholm, H. W., Hellberg, E., Bergeron, Y., Niklasson, M. 2014. Multi-century reconstruction of fire activity in Northern European boreal forest suggests differences in regional fire regimes and their sensitivity to climate. Journal of Ecology 102: 738-748. 
Drobyshev I., Bergeron, Y., de Vernal, A., Moberg, A., Ali, A.A., Niklasson, M. 2016. Atlantic SSTs control regime shifts in forest fire activity of Northern Scandinavia. Scientific reports 6: 22532.

Ennevaara P.A. 1954. Metsäpalot vuosina 1952-1953. Acta Forestalia Fennica, 61: 1-17. [Forest fires in Finland 1952-1953 [In Finnish with an English Abstract].]

Fire act 1933. Finnish act 202/1933. [In Finnish.]

Fire act 1960. Finnish act 465/1960. [In Finnish.]

Gauthier, S., Bernier, P., Kuuluvainen, T., Shvidenko, A.Z., Schepaschenko, D.G. 2015. Boreal forest health and global change. Science 349: 819-822.

Granström, A. 1993. Spatial and temporal variation in lightning ignitions in Sweden. Journal of Vegetation Science 4: 737-744.

Granström, A. 2001. Fire management for biodiversity in the European boreal forest. Scandinavian Journal of Forest Research 16: 62-69.

Granström, A., Niklasson, M. 2008. Potentials and limitations for human control over historic fire regimes in the boreal forest. Philosophical Transactions of the Royal Society B Biological Sciences 363: 2353-2358.

Granström, A. 2020. Brandsommaren 2018. - Vad hände, och varför? Myndigheten för samhällsskydd och beredskap. $151 \mathrm{pp}$. [The fire summer of 2018. - What happened, and why? Swedish Civil Contingencies Agency [In Swedish].]

Gromtsev, A.N. 1993. Landscape patterns of structure and dynamics of middle taiga forests in the Republic of Karelia. 160 pp. [Ландшафтные закономерности среднетаежных лесов Карелии] Petrozavodsk [In Russian].]

Gromtsev, A.N. 1996. Retrospective analysis of natural fire regimes in landscapes of Eastern Fennoscandia and problems of their anthropogenic transformation. In: Goldammer J.G., Furyaev, V. (eds.): Fire in Ecosystems of Boreal Eurasia. Forestry Sciences 48: 45-54. Dordrecht-Boston-London.

Gromtsev, A.N. 2002. Natural disturbance dynamics in the boreal forests of European Russia: a review. Silva Fennica 36: 41-55.

Haapanen A., Siitonen P. 1978. Kulojen esiintyminen Ulvinsalon luonnonpuistossa. Silva Fennica 12: 3. [Forest fires in Ulvinsalo strict nature reserve [In Finnish with an English summary].]

Haataja, V. 1998. Tuntsan palo ja suuri nokisavotta. Koillismaan Kirjapaino Oy, Kuusamo. 48 pp. [Tuntsa wildfire [In Finnish].]

Heikinheimo, O. 1915. Kaskiviljelyksen vaikutus Suomen metsiin. Acta Forestalia Fennica, 4. [The effect of shifting cultivation on forests in Finland [In Finnish with German summary].]

Hellberg, E., Niklasson, M., Granström, A. 2004. Influence of landscape structure on patterns of forest fires in boreal forest landscapes in Sweden. Canadian Journal of Forest Research 34: $332-338$.

Högbom, A.G. 1934. Om skogseldar förr och nu och deras roll i skogarnas utvecklingshistoria. Norrländskt handbibliotek XIII. $101 \mathrm{pp}$. [On forest fires past and present and their role in the developmental history of the forests [In Swedish].]

IPCC, 2013: Climate Change 2013: The Physical Science Basis. Contribution of Working Group I to the Fifth Assessment Report of the Intergovernmental Panel on Climate Change (Stocker, T. F., Qin, D., Plattner, G.-K., Tignor, M., Allen, S. K., Boschung, J., Nauels, A., Xia, Y., Bex, V., Midgley, P. M. (eds.)). Cambridge University Press, Cambridge, United Kingdom and New York, USA, 1535 pp.

Kasin, I., Blanck, Y.-1., Storaunet, K.O., Rolstad, J., Ohlson, M. 2013. The charcoal record in peat and mineral soil across a boreal landscape and possible linkages to climate change and recent fire history. The Holocene 23: 1052-1065. 
Kilpeläinen, A., Kellomäki, S., Strandman, H., Venäläinen, A. 2010. Climate change impacts on forest fire potential in boreal conditions in Finland. Climatic Change 103: 383-398.

Kinnman, G. 1936. Skogseldrisken och väderleken. Svenska Skogsvårdsförbundets Tidskrift 34: 481-512.[Forest fire danger and weather [In Swedish].]

Kohh, E. 1975. A study of forest fires and hard pan in the forests of Älvdalen. Svenska Skogsvårdsförbunds Tidskrift 73: 299-336.

Laitakari, E. 1960. Metsähallinnon vuosisataistaival 1859-1959. Silva Fennica: 197. [A century of Finnish State forestry 1859-1959 [In Finnish with English summary].]

Larjavaara, M. 2005. Climate and forest fires in Finland - influence of lightning-caused ignitions and fuel moisture. Dissertationes Forestales 5, Department of Forest Ecology, Faculty of Agriculture and Forestry. University of Helsinki. 35 pp.

Lehmusluoto, P. 1956. Kulot, kulontorjunta ja metsäpalovakuutus. In: Jalava M, Lihtonen V, Heiskanen V, Sippola H (eds.): Metsäkäsikirja 1. Kustannusosakeyhtiö Kivi, Helsinki, 717742. [Forest fires, forest fire protection, and forest fire insurance. In Forest Handbook 1 [In Finnish].]

Lehtonen, H., Huttunen, P., Zetterberg, P. 1996. Influence of man on forest fire frequency in North Karelia, Finland, as evidenced by scars on Scots pines. Annales Botanici Fennici 33: 257-263.

Lehtonen, H., Huttunen, P. 1997. History of forest fires in eastern Finland from the fifteenth century AD - the possible effects of slash-and-burn cultivation. The Holocene 7: 223-228.

Lehtonen, I., Ruosteenoja, K., Jylhä, K. 2014a. Projected changes in European extreme precipitation indices on the basis of global and regional climate model ensembles. International Journal of Climatology 34: 1208-1222.

Lehtonen, I., Ruosteenoja, K., Venäläinen, A., Gregow, H. 2014b. The projected 21st century forest-fire risk in Finland under different greenhouse gas scenarios. Boreal Environment Research 19: 127-139.

Lehtonen, I., Venäläinen, A. 2020. Metsäpalokesä 2018 muuttuvassa ilmastossa poikkeuksellinen vuosi vai uusi normaali? Ilmatieteen laitos, Helsinki, 26 pp. + Appendix. [Forest fire season 2018 in a changing climate - an exceptional year or new normal? Finnish Meteorological Institute [in Finnish with abstract in English].]

Lindberg, H., Punttila, P., Vanha-Majamaa, I. 2020. The challenge of combining variable retention and prescribed burning in Finland. Ecological Processes 9.

Lindberg, H., Aakala, T., Vanha-Majamaa, I. 2021. Moisture content variation of ground vegetation fuels in boreal mesic and sub-xeric mineral soil forests in Finland. International Journal of Wildland Fire 30: 283-293.

Mäkelä, H.M., Laapas, M., Venäläinen, A. 2012. Long-term temporal changes in the occurrence of high forest fire danger in Finland. Natural Hazards and Earth System Sciences 12: 2591-2601.

Mäkelä, H., Venäläinen, A., Jylhä, K., Lehtonen, I., Gregow, H. 2014. Probabilistic projections of climatological forest fire danger in Finland. Climate Research 60.

Niklasson, M., Granström, A. 2000. Numbers and sizes of fires: Long-term spatially explicit fire history in a Swedish boreal landscape. Ecology 81: 1484-1499.

Niklasson, M., Drakenberg, B. 2001. A 600-year tree-ring fire history from Norra Kvills National Park, southern Sweden: implications for conservation strategies in the hemiboreal zone. Biological Conservation 101: 63-71.

Niklasson, M. 2011. Brandhistorik i sydöstra Sverige. Länsstyrelserna 2011:14.

Olsson, F., Gaillard, M.-J., Lemdahl, G., Greisman, A., Lanos, P., Marguerie, D., Marcoux, N., Skoglund, P., Wäglind, J. 2010. A continuous record of fire covering the last 10,500 calendar years from southern Sweden - The role of climate and human activities. Palaeogeography, Palaeoclimatology, Palaeoecology 291: 128-141. 
Ou, T. 2017. Droughts and wildfires in Sweden. Myndigheten för samhällsskydd och beredskap [Swedish Civil Contingencies Agency]. 20 pp.

Parviainen, J. 1996. Impact of fire on Finnish forests in the past and today. Silva Fennica 30: 353-359.

Piha, A., Kuuluvainen, T., Lindberg, H., Vanha-Majamaa, I. 2013. Can scar-based fire history reconstructions be biased? An experimental study in boreal Scots pine. Canadian Journal of Forest Research 43: 669-675.

Pobedinsky et al., 1982. Methodological recommendations for forest type classification in the European boreal forests of North-Western part of Russia. [Побединский А.В., Лазарев Ю.А., Ханбеков Р.И., Орлов А.Я., Абатуров Ю.Д. Рекомендации по выделению коренных и производных групп типов леса лесной зоны Европейской части РСФСР]. [In Russian]

Power, M.J., Marlon, J., Ortiz, N., Bartlein, P.J., Harrison, S.P., Mayle, F.E., Ballouche, A., Bradshaw, R.H.W., Carcaillet, C., Cordova, C., Mooney, S., Moreno, P. J., Prentice, I.C., Thonicke, K., Tinner, W., Whitlock, C., Zhang, Y., Zhao, Y., Ali, A.A., Anderson, R.S., Beer, R., Behling, H., Briles, C., Brown, K.J., Brunelle, A., Bush, M., Camill, P., Chu, G. Q., Clark, J., Colombaroli, D., Connor, S., Daniau, A.-L., Daniels, M., Dodson, J., Doughty, E., Edwards, M.E., Finsinger, W., Foster, D., Frechette, J., Gaillard, M.J., Gavin, D.G., Gobert, E., Haberle, S., Hallett, D.J., Higuera, P., Hope, G., Horn, S., Inoue, J., Kaltenrieder, P., Kennedy, L., Kong, Z.C., Larsen, C., Long, C.J., Lynch, J., Lynch, E.A., McGlone, M., Meeks, S., Mensing, S., Meyer, G., Minckley, T., Mohr, J., Nelson, D.M., New, J., Newnham, R., Noti, R., Oswald, W., Pierce, J., Richard, P.J.H., Rowe, C., Sanchez Goñi, M.F., Shuman, B.N., Takahara, H., Toney, J., Turner, C., Urrego-Sanchez, D.H., Umbanhowar, C., Vandergoes, M., Vanniere, B., Vescovi, E., Walsh, M., Wang, X., Williams, N., Wilmshurst, J., Zhang, J. H. 2008. Changes in fire regimes since the Last Glacial Maximum: an assessment based on a global synthesis and analysis of charcoal data. Climate Dynamics 30: 887-907.

Päätalo, M.-L. 1998. Factors influencing occurrence and impacts of fires in Northern European forests. Silva Fennica 32: 185-202.

Report of Fire Prevention Committee 1926. Finnish Committee Reports 1/1926 [In Finnish].

Rogers, B., Soja, A., Goulden, M., Randerson, J. 2015. Influence of tree species on continental differences in boreal fires and climate feedbacks. Nature Geoscience 8: 228-234.

Rolstad, J., Blanck, Y.-1., Storaunet, K.O. 2017. Fire history in a western Fennoscandian boreal forest as influenced by human land use and climate. Ecological Monographs 87: 219-245.

Saari, E. 1923. Kuloista, etupäässä Suomen valtionmetsiä silmällä pitäen. Tilastollinen tutkimus. Acta Forestalia Fennica, 26: 1-155. [Forest fires in Finland, with special reference to State forests. Statistical investigation [In Finnish with an English summary].]

Schimmel, J., Granström, A. 1997. Fuel succession and fire behavior in the Swedish boreal forest. Canadian Journal of Forest Research 27: 1207-1216.

Shvidenko, A., Goldammer, J.G. 2001. Fire situation in Russia. International Forest Fire News 24: 41-59.

Sjöström, J., Plathner, F.V., Granström, A. 2019. Wildfire ignition from forestry machines in boreal Sweden. International Journal of Wildland Fire 28: 666-677.

Sjöström, J., Granström, A. 2020. Skogsbränder och gräsbränder i Sverige. Trender och mönster under senare decennier. Myndigheten för samhällsskydd och beredskap. [Wildfires in Sweden - trends and patterns during recent decades. Swedish Civil Contingencies Agency [In Swedish].]

Soisalo, J. 2021. Metsäpalojen tähystystoiminnan arviointi ja kehittäminen. Diplomityö. Oulun yliopisto, Tuotantotalouden tutkinto-ohjelma. 84 pp. [Evaluation and Development of Forest 
Fire Detection. University of Oulu, Degree Programme of Mechanical Engineering. Master's thesis [In Finnish with English abstract].]

Tanskanen, H., Venäläinen, A., Puttonen, P., Granström, A. 2005. Impact of stand structure on surface fire ignition potential in Picea abies and Pinus sylvestris forests in southern Finland. Canadian Journal of Forest Research 35: 410-420.

Tanskanen, H., Granström, A., Venäläinen, A., Puttonen, P. 2006. Moisture dynamics of moss dominated surface fuel in relation to the structure of Picea abies and Pinus sylvestris stands. Forest Ecology and Management 226: 189-198.

The state report on the environmental conditions in the Republic of Karelia in 2019. [Государственный доклад о состоянии окружающей среды Республики Карелия в 2019 г.]. Ministerstvo prirodnykh resursov i ekologii Respubliki Kareliya. Redaktsionnaya kollegiya: A.N.Gromtsev (glavnyi redaktor), O.L.Kuznetsov, G.T.Shkiperova. [Ministry of Natural Resources and Environment of the Republic of Karelia. Editorial board: A.N. Gromtsev (chief editor), O. L. Kuznetsov, G. T. Shkiperova.] Petrozavodsk, 2020 [In Russian]

Tonteri. T., Salemaa, M., Rautio, P., Hallikainen, V., Korpela. L., Merilä, P. 2016. Forest management regulates temporal change in the cover of boreal plant species. Forest Ecology and Management 381: 115-124.

Wallenius, T. 2004. Fire histories and tree ages in unmanaged boreal forests in Eastern Fennoscandia and Onega peninsula. Academic Dissertation, Department of Biological and Environmental Sciences, Faculty of Biosciences, and Department of Forest Ecology, Faculty of Agriculture and Forestry. University of Helsinki. 61 pp.

Wallenius, T. H., Kuuluvainen, T., Vanha-Majamaa, I. 2004. Fire history in relation to site type and vegetation in Vienansalo wilderness in eastern Fennoscandia, Russia. Canadian Journal of Forest Research 34: 1400-1409.

Wallenius, T., Lilja, S., Kuuluvainen, T. 2007. Fire history and tree species composition in managed Picea abies stands in southern Finland: Implications for restoration. Forest Ecology and Management 250: 89-95.

Wallenius, T. 2008. Menneet metsäpalot Kalevalan kankailla. Metsähallitus, Vantaa. 46 pp. [Past forest fires in Kalevala National Park and neighbourhood [In Finnish with English abstract].]

Wallenius, T., Kauhanen, H., Herva, H., Pennanen, J. 2010. Long fire cycle in northern boreal Pinus forests in Finnish Lapland. Canadian Journal of Forest Research 40: 2027-2035.

Wallenius, T. 2011. Major decline in fires in coniferous forests - reconstructing the phenomenon and seeking for the cause. Silva Fennica 45: 139-155.

Yang, W., Gardelin, M., Olsson, J., Bosshard, T. 2015. Multi-variable bias correction: application of forest fire risk in present and future climate in Sweden. Natural Hazards and Earth System Sciences 15: 2037-2057.

Zackrisson, O. 1977. Influence of forest fires on the North Swedish boreal forest. Oikos 29: $22-32$.

Östlund, L., Zackrisson, O., Axelsson, A.-L. 1997. The history and transformation of a Scandinavian boreal forest landscape since the 19th century. Canadian Journal of Forest Research 27: 1198-1206. 


\title{
4. Climate change increases the risk of forest fires
}

\author{
Leif Backman, Tuula Aalto, Ilari Lehtonen, Laura Thölix, Ilkka Vanha-Majamaa, Ari \\ Venäläinen
}

In this chapter, the impacts of projected climate change on the forest fire risk are discussed (Fig. 4.1). As in other regions in northern high latitudes, also in the Fennoscandian area, climate is expected to warm at a faster rate compared to the global average. This warming will lead to enhanced evapotranspiration, which further tends to decrease soil moisture content. However, this may be partly offset by an increase in precipitation levels. Nevertheless, the vast majority of literature suggests that climate change will increase the fire risk in the Fennoscandian area during this century. This would mean that severe fire weather conditions would occur more frequently in the future. Still, severe fire weather conditions, like those seen in 2018 when several large fires raged in Sweden, will most likely remain relatively rare unless the most dramatic warming scenarios are realised, although there are considerable differences among the fire weather projections based on different climate models. After a literature review presented in Section 4.1, we then present results from a novel analysis on climate change impacts on fire regimes based on the JSBACH-SPITFIRE model in Section 4.2. The model takes into account changes in vegetation growth and fuel loads, and simulates the fire risk, number of fires and the burnt area. In accordance with previous studies, the results indicated mainly increasing fire risk as a response to projected climate change. The accuracy of the model could probably be increased with more precise information on forest management and its effects, especially on the amount of fine fuels and thereby fire risks.

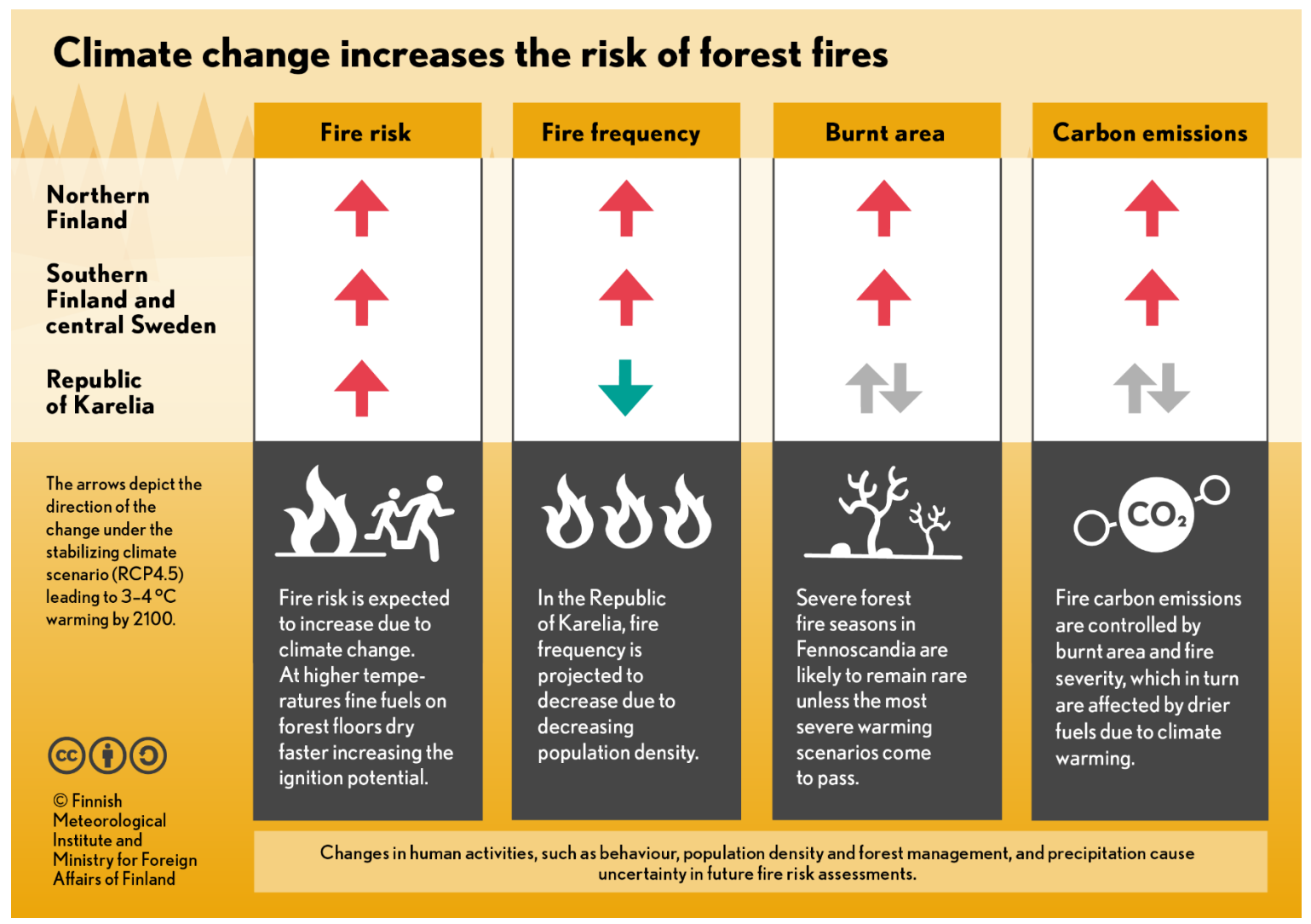

Figure 4.1. Infographics 'Climate change increases the risk of forest fires' summarising the main findings of the chapter. 


\subsection{Increasingly severe fire weather creates more suitable conditions for forest fires in the future}

During the present century, global mean temperature is projected to increase, most likely by approximately $1-4{ }^{\circ} \mathrm{C}$ (Collins et al., 2013). The rate of warming depends largely on the future evolution of global greenhouse gas emissions. In the most recent Fifth Assessment Report of the Intergovernmental Panel on Climate Change (IPCC, 2013), four alternative atmospheric greenhouse gas concentration trajectories were evaluated. These are termed Representative Concentration Pathway (RCP) scenarios (van Vuuren et al., 2011). The RCPs are labelled after a change in radiative forcing level as RCP2.6, RCP4.5, RCP6.0 and RCP8.5, with the numbers indicating radiative forcing values in $\mathrm{W} / \mathrm{m}^{2}$ in 2100 , relative to the preindustrial era. Corresponding evolutions of global carbon dioxide emissions are displayed in Figure 4.2. The most commonly used RCPs include the pathways RCP2.6, RCP4.5 and RCP8.5 representing worlds with very low, intermediate and high greenhouse-gas emissions, respectively. However, even the RCP2.6 pathway is projected to lead to a warming that most likely exceeds the 2015 Paris Agreement aiming to limit global warming below $2{ }^{\circ} \mathrm{C}$ as compared to the preindustrial level, taking into account that globally, temperatures have already increased by about $1{ }^{\circ} \mathrm{C}$ since the 19th century (Sanderson et al., 2016).

\section{REPRESENTATIVE CONCENTRATION PATHWAYS (RCP)}

For the Fifth Assessment Report of IPCC, the scientific community has defined a set of four new greenhouse gas scenarios, referred to as the Representative Concentration Pathways (RCP).
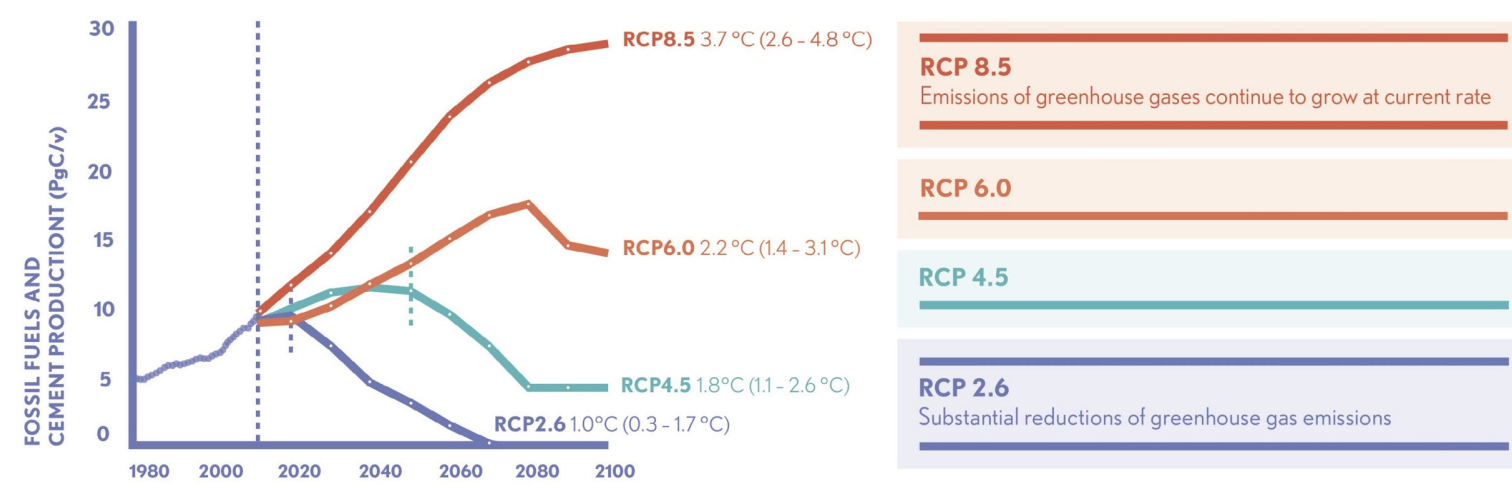

Figure 4.2. Global total amount of carbon dioxide emissions in gigatonnes (a billion tonnes) of carbon per year according to representative concentration pathway (RCP) scenarios until 2100. Projected multi-model mean change in global mean temperature from 1986-2005 to 2081-2100 is also shown with a confidence interval for each RCP scenario (source: climateguide.fi). 

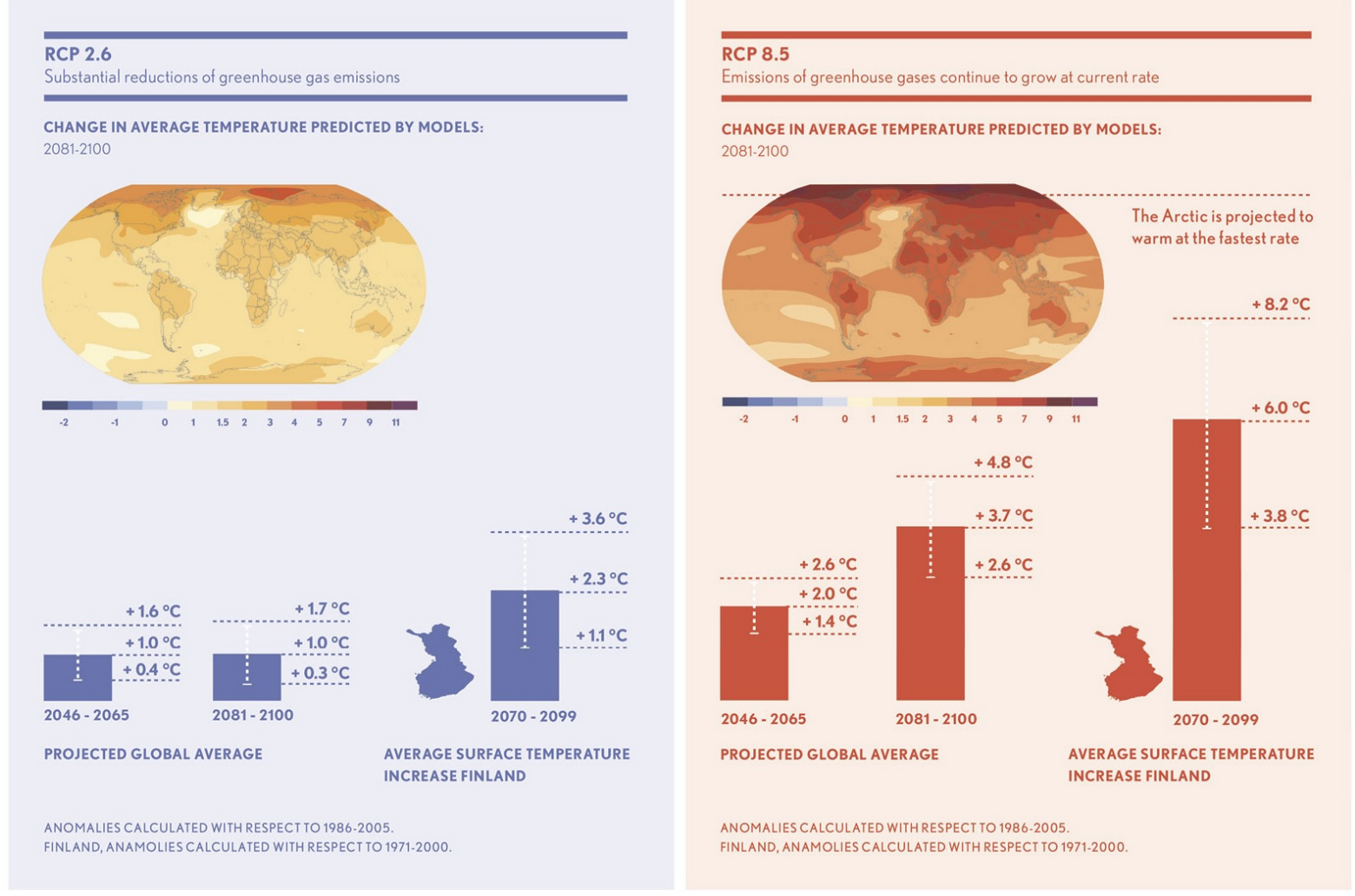

Figure 4.3. Projected changes in temperature. Left: The change if greenhouse gas emissions are reduced substantially as in RCP2.6. Right: The change if the emissions continue to grow as in RCP8.5. The projected change shown in the maps represents multi-model mean change. For global and Finnish average values, a confidence interval indicating the likely range of the temperature change is shown in addition to the multi-model mean change (source: climateguide.fi).

Two key regional features in the pattern of projected temperature change include larger warming over land areas compared to oceans, and amplified warming in the highest latitudes (Fig. 4.3). The latter phenomenon, known as Arctic amplification, is largely caused by sea ice loss (Serreze and Barry, 2011; Dai et al., 2019). On an annual average, the global ratio of land to ocean warming is approximately 1.5 while the projected warming in the Arctic is more than twofold compared to the global average. In Finland and elsewhere in Fennoscandia, the rate of warming is expected to exceed the global average by a factor of approximately two. In addition to temperature increase, annual precipitation levels are also projected to increase in Fennoscandia. Projected precipitation change, however, is associated with a larger uncertainty compared to temperature change. Moreover, temperature and especially precipitation are projected to increase more in winter than in summer (e.g. Räisänen and Ylhäisi, 2015). In summer, projected changes in precipitation are small, most likely between 0 and $10 \%$ in most of Fennoscandia (Ruosteenoja et al., 2016). This increase is largely due to intensifying heavy precipitation (e.g. Lehtonen et al., 2014a). Year-to-year variability in precipitation may also increase in summer.

Meteorological forest fire risk is largely determined by topsoil moisture content. Increase in temperatures lead to enhanced evapotranspiration which, in northern Europe, is partly offset by increasing precipitation. On average, however, soil moisture is also projected to decrease as a response to global warming in Fennoscandia (Ruosteenoja et al., 2018; Spinoni et al., 2018). 
The change is most pronounced in spring and early summer after snowmelt, which will take place earlier in a warmer climate. However, anomalously dry soil conditions are projected to also occur more frequently in the future later in summer (Ruosteenoja et al., 2018; Spinoni et al., 2018). The intensification of long-lasting droughts has already been observed throughout Europe, attributed mainly to increasing air temperatures (Manning et al., 2019).

Due to a decreasing soil moisture content, forest fire risk has generally been expected to increase over the circumboreal region with rising air temperatures (e.g. Flannigan et al., 1998, 2000; Stocks et al., 1998). Similar results have been obtained in more recent studies, focusing mainly on Canada and Russia (Flannigan et al., 2005a, 2005b, 2009; Wotton et al., 2010; de Groot et al., 2013; Shvidenko and Schepaschenko, 2013; Sherstyukov and Sherstyukov, 2014). The climate change impact on forest-fire risk has also recently been assessed in several studies focusing on Finland (Kilpeläinen et al., 2010; Mäkelä et al., 2014a; Lehtonen et al., 2014b, 2016). These studies have consistently indicated that fire risk will increase with rising air temperatures. For example, Lehtonen et al. (2016) estimated that assuming the current relationship between weather and the occurrence of forest fires, the number of fires larger than 10 ha in size may double or even triple during this century. The increased fire weather severity is expected to challenge fire management and can even push current suppression capacity beyond a tipping point, resulting in a substantial increase in large fires (de Groot et al., 2013). Moreover, the increasing fire danger is expected to result in increasing carbon emissions from fires (Migliavacca et al., 2013). Forest fires can also dramatically increase black carbon mass concentration even in the lowermost stratosphere (Ditas et al., 2018, see chapter 6). Nevertheless, considerable uncertainty exists in the rate of the projected increase in the severity of fire weather. In addition, Yang et al. (2015) predicted that in northern Sweden the fire risk could even decrease due to increasing precipitation, so even the direction of the change is not completely clear.

Recently, numerous large forest fires occurred in Sweden during the exceptionally warm and dry summer of 2018. These fires burnt almost 25000 hectares of forest (Sjöström and Granström, 2020). The forest fire season was also difficult in Finland, although not as difficult as the summer of 2006 and with a burned area of ca. 1200 hectares not merely as outstanding as in Sweden (Ketola, 2018). Krikken et al. (2019) estimated that so far global warming has played a small role in increasing the fire risk in Sweden, but it will have a more pronounced role in the future. According to their estimates, the maximum forest fire risk in July 2018 had return times of ca. 24 years for southern and northern Sweden, whereas Lehtonen and Venäläinen (2020) evaluated that for the seasonally averaged fire risk, the return times were more than 50 years in many places in Sweden and Finland. Lehtonen and Venäläinen (2020) furthermore concluded that summers with similar or higher forest-fire risk as in 2018 and also 2006 will most likely remain rare in Finland, at least until the mid- $21^{\text {st }}$ century, but if the most dramatic warming scenarios are realised, similarly difficult forest fire seasons might occur in the late $21^{\text {st }}$ century as often as every few years. Moreover, Krikken et al. (2019) estimated that with a $2{ }^{\circ} \mathrm{C}$ warming, the risk of such events as the fires of 2018 in Sweden would roughly double relative to the pre-industrial climate. This increased fire weather risk is mainly attributed to the increase in temperature, as Krikken et al. (2019) did not find a clear change in the projected occurrence of prolonged dry periods in summer months.

To supplement these previous studies focusing mainly on the impact of varying meteorological conditions on the fire risk, in the next section we present the results from new analyses conducted with the land surface model JSBACH (Kaminski et al., 2013) that can be used in evaluating the actual fire activity in changing climatic and environmental conditions. 


\subsection{Climate conditions and human influence determine the future fire regimes in Fennoscandia}

\subsubsection{Climate change and its effect on fire risk in Fennoscandia}

The effect of projected climate change on forest fires in Fennoscandia was simulated using the land surface model JSBACH, which is the land model in the Earth system models of the MaxPlanck Institute for Meteorology (Mauritsen et al., 2019). Regional simulations were carried out using the JSBACH-SPITFIRE model over the period 1951-2100. Here, the model domain was limited to the land area within $55-71^{\circ} \mathrm{N}$ and $5-38^{\circ}$ E. SPITFIRE is a mechanistic fire model (Thonicke et al., 2010; Lasslop et al., 2014), which is driven by meteorology, vegetation cover, fuel load and fuel properties. The model simulates the fire risk, the number of fires and the burnt area fraction. The vegetation growth and changes in the fuel load are simulated by the JSBACH land surface model, which is driven by climate model data.

The climate in the area represented by the model domain is warming at a pace that is exceeding the global average (chapter 4.1). In our simulations the JSBACH-SPITFIRE was driven by downscaled and bias-corrected meteorological data from the EURO-CORDEX initiative (Jacob et al., 2014). In the bias correction the simulated and observed distribution frequency of precipitation, for example, is matched, which means that systematic errors in the simulated data can be removed (e.g. Yang et al., 2010). The correction to the distribution can then also be made to future climate projections. We used data produced for the EUR-44 domain, with a spatial resolution of ca. $50 \mathrm{~km}\left(0.44^{\circ}\right)$, which was interpolated into a $0.5^{\circ}$ resolution for our model domain. The data we used is based on the global driver models CanESM2, CNRM-CM5 and MIROC5. These driving models represent a mid-range when looking at the projected change in temperature and precipitation for Finland under RCP4.5 and RCP8.5 (Ruosteenoja, 2016). This means that the projected changes in the fire regimes could be greater or smaller than those presented here, if we had chosen data based on Earth system models projecting more extreme changes. The regional climate model RCA4 (Samuelsson et al., 2011) had been used as a downscaling model for all three driving models, and a distribution-based bias-correction method had been applied for all data sets that we used (e.g. Yang et al., 2010). We used daily bias corrected data of precipitation and temperature from 1951 to 2100 for both RCP4.5 and RCP8.5 climate change projections. In addition, daily data for relative humidity, wind speed, and longwave and shortwave radiation were used for the historical (1951-2005) and scenario period (2006-2100).

Compared to other seasons, conditions in the summer months are more relevant for forest fires, even though other factors in other seasons may also have an effect. For example, shorter snow cover and soil freezing periods could leave trees unprotected against abrupt weather changes and enable anomalous droughts earlier in spring due to earlier snowmelt and subsequent soil drying (Ruosteenoja, 2018). The projected changes in summer averages of temperature and precipitation from 1981-2010 to 2071-2100, under RCP4.5 and RCP8.5, are shown in Figures 4.4 and 4.5. The largest increase in temperature is seen in the data based on CanESM2, ca. 2$3{ }^{\circ} \mathrm{C}$ under RCP4.5 (a) and ca. $4.5-5.5^{\circ} \mathrm{C}$ under RCP8.5 (b). The smallest increase is seen in the data based on CNRM-CM5, ca. $1-2{ }^{\circ} \mathrm{C}$ (e) and ca. $3-4{ }^{\circ} \mathrm{C}(\mathrm{f})$, respectively. Some mountain regions show a larger increase in temperature. The largest increase in precipitation is seen in the data based on CNRM-CM5, ca. 0-40\% under RCP4.5 (e) and ca. 10-50\% under RCP8.5 (f). The smallest increase in precipitation is seen in the data based on CanESM2, ca. -10 to 20 $\%$ (a) and ca. 0 to $20 \%$ (b), respectively. The projected change in the data based on MIROC5 (c, d) falls in between the two other driver data sets for both temperature and precipitation. The 
changes in both temperature and precipitation are larger under RCP8.5 than under RCP4.5 in all models due to substantially larger greenhouse gas concentrations by the end of the century. However, the models project different ranges of change, and the spatial patterns are also different within the domain, as seen in Figures 4.4 and 4.5.
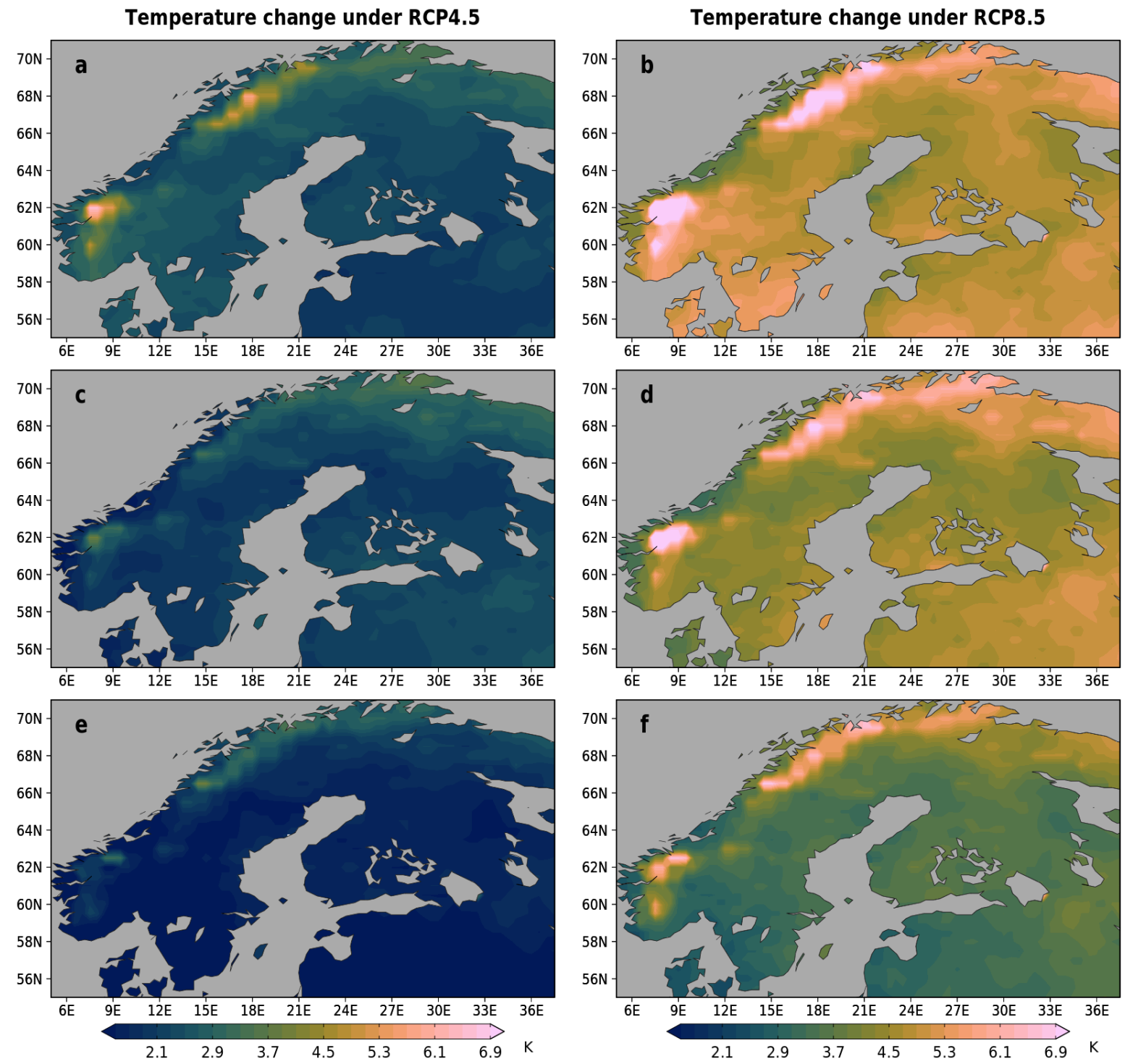

Figure 4.4. Projected change in the temperature $(\mathrm{K})$ during summer months (JJA) from the period 1981-2010 to 2071-2100 under the RCP4.5 and RCP8.5 climate change scenarios. The plots show downscaled and bias-corrected EURO-CORDEX data $\left(0.5^{\circ} \times 0.5^{\circ}\right)$. Data based on the global driver models CanESM2, MIROC5 and CNRM-CM5 are shown in the top, middle and bottom panels, respectively. 

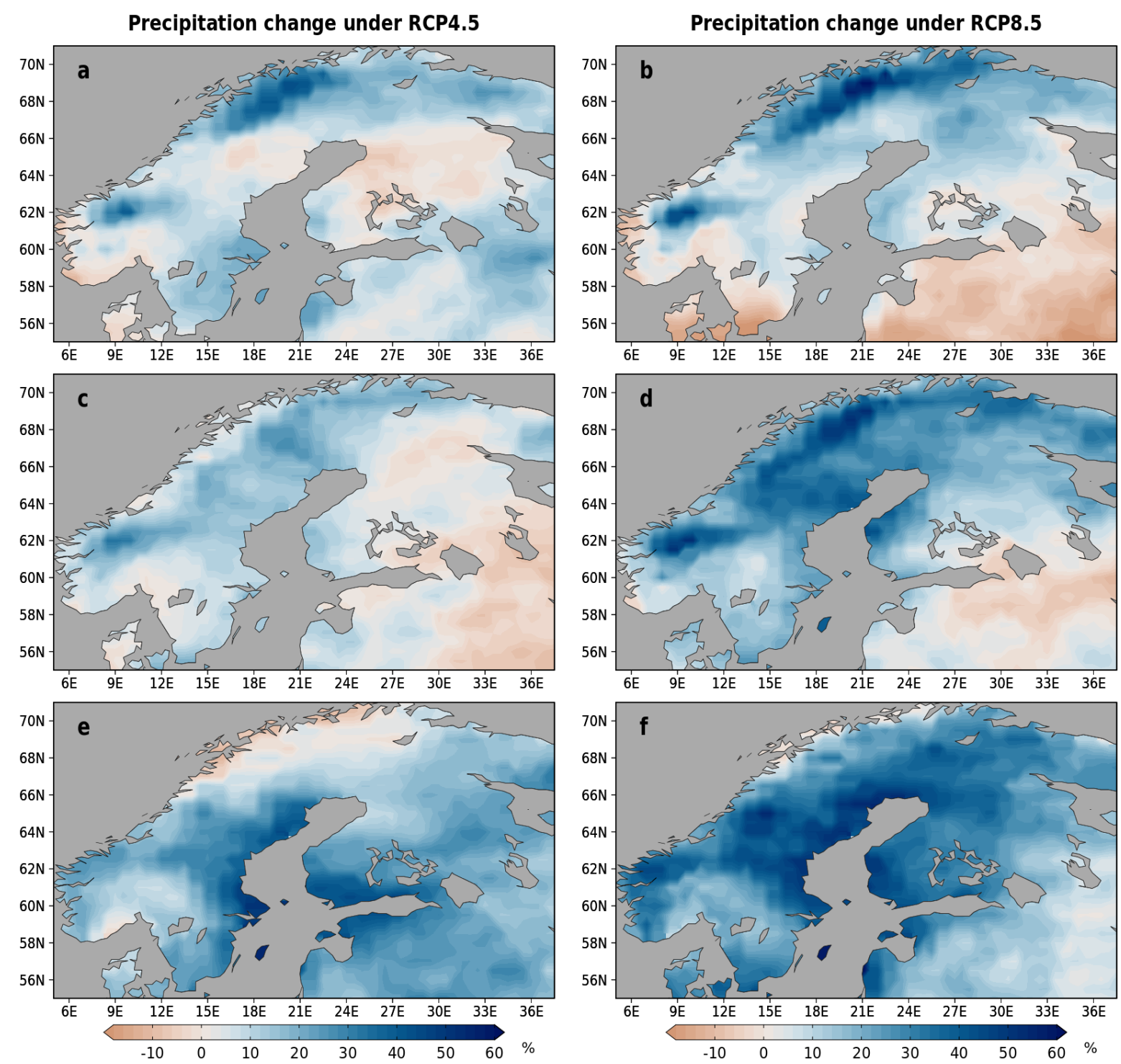

Figure 4.5. Projected change in precipitation (\%) during summer months (JJA) from the period 1981-2010 to 2071-2100 under the RCP4.5 and RCP8.5 climate change scenarios. The plots show downscaled and bias-corrected EURO-CORDEX data $\left(0.5^{\circ} \times 0.5^{\circ}\right)$. Blue indicates increased precipitation. Data based on the global driver models CanESM2, MIROC5 and CNRM-CM5 are shown in the top, middle and bottom panels, respectively.

Ignition, either lightning- or human-caused, will lead to a spreading fire only when there is fuel available and the fuel is dry enough. The amount of dead fuel, which largely depends on the above-ground litter, is simulated by the JSBACH as a balance between litter produced by the vegetation (e.g. dead leaves and branches) and soil respiration (i.e. decomposition of organic matter). The number of fires is determined by the presence of fuel, lightning frequency and population density, while the amount, moisture and characteristics of dead fuel control the surface fire intensity, burnt area and completeness of combustion. The damage to plants, and hence combustion of live fuel, depends on the surface fire intensity. The land use in the simulations was derived from CORINE (EEA, 2020) and ESA LandUse-CCI (ESA, 2019) data, and represents the current land cover of Fennoscandia. The land use was kept unchanged for the simulated period. The forest fraction and the simulated above-ground woody litter during 
the reference period 1981-2010 are shown in Figure 4.6. The above-ground woody litter, and hence the amount of dead fuel, correlates well with the forest fraction.
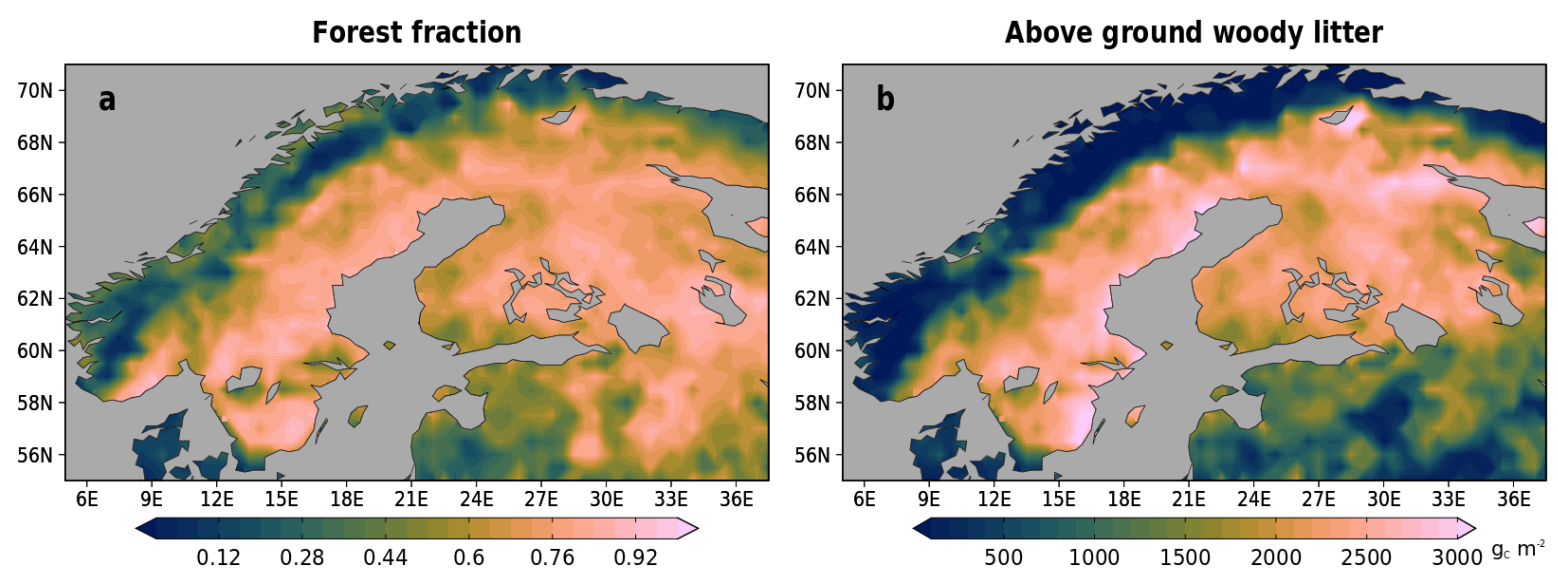

Figure 4.6. a) The forest fraction based on CORINE and ESA LandUse-CCI data; b) aboveground woody litter $\left(\mathrm{g}_{\mathrm{C}} \mathrm{m}^{-2}\right)$ during the reference period 1981-2010.

Climate change brings positive effects to boreal ecosystems regarding tree growth due to increasing temperature and $\mathrm{CO}_{2}$ fertilisation. The growing season is lengthening, and boreal trees will become more productive over the course of the year. However, climate change may also elevate the risk of forest fires and subsequently increase the release of carbon to the atmosphere. In addition, the $\mathrm{CO}_{2}$ release from soil and vegetation, i.e. respiration, also increases alongside increasing temperatures, and continues at higher levels during autumn and winter when light availability already suppresses photosynthesis (e.g. Mäkelä et al., 2020). Therefore, the increased carbon uptake during spring may partly be offset by increased soil respiration. In our simulations the annual sum of the net primary productivity (NPP) in the forested area of the domain is projected to increase by $10-20 \%$ from 1981-2010 to $2071-2100$ under the RCP 4.5 and about $20-40 \%$ under the RCP8.5. Simultaneously, soil respiration increases by ca. $10-25 \%$ and $20-40 \%$, respectively.

Climate change affects both the amount and the properties of fuel, i.e. above-ground litter. In Figure 4.7 an example is shown of the projected change in litter production and soil respiration, and their combined effect on the above-ground woody litter. The data is from a simulation driven by data from the MIROC5 model under RCP4.5. In the simulation the NPP increases, and as a result the production of litter also increases (Fig. 4.7a). However, due to the changes in temperature and soil moisture, the decomposition, or respiration, of litter also increases (Fig. 4.7b). The net effect is that the woody litter decreases by a few percent in many areas, meaning less fuel is available (Fig. 4.7c). The decrease in woody litter is greater in the simulations with greater increases in temperature, due to further increased respiration. The changes in the aboveground litter are, however, not straightforward. Drought periods can also increase litter production temporarily due to increased plant mortality. 

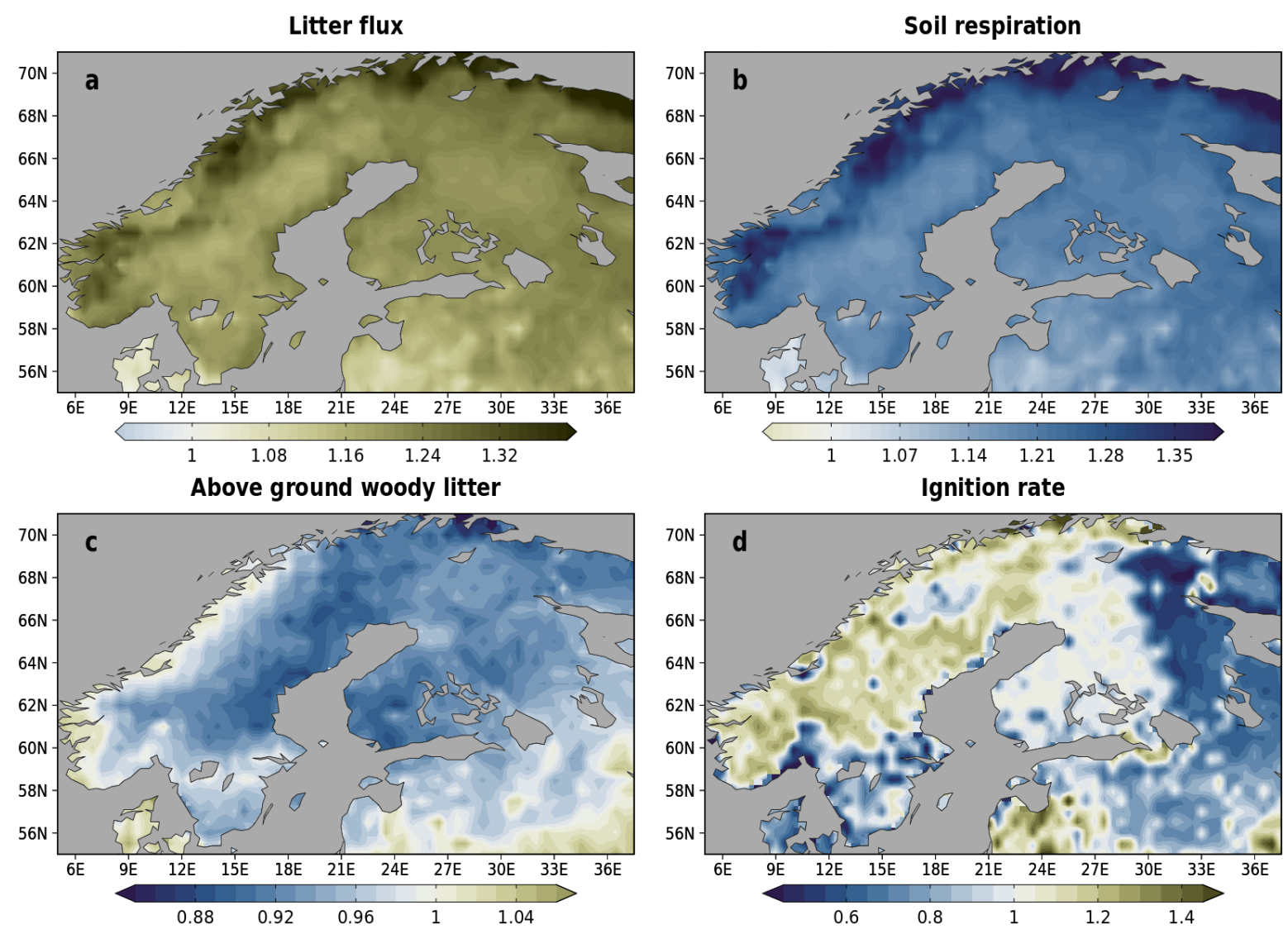

Figure 4.7. Projected change by 2071-2100 relative to the reference period 1981-2010 in a) litter production; b) soil respiration; c) above-ground woody litter; d) ignition events. The results are shown for a simulation driven by data from MIROC5 under RCP4.5. Green indicates a change that may be associated with an increased risk of forest fires.

The SPITFIRE model considers ignition events caused by both lightning and human actions. The lightning ignition rate was obtained from a flash climatology for northern Europe compiled by the Finnish Meteorological Institute (Mäkelä et al., 2014b), based on observations from lightning location sensors. The climatology was appended east of $32^{\circ} \mathrm{E}$ with the LIS/OTD climatology (Cecil et al., 2015), corrected as in Lasslop et al. (2014). It has been estimated that the number of flashes within the studied region could increase due to climate change by approximately 5-15\% under RCP4.5, and 10-30\% under RCP8.5 by 2100 (Groenemeijer, 2016), which would increase the number of ignition events to some extent. However, this change was not considered in our simulations.

The human-caused ignition events are calculated based on population density, which is weighted by the propensity of humans to ignite a fire - this varies by region. The ignition rate increases with population density only to a certain limit, until the built environment starts to decrease the possibility of wildfires (Thonicke et al., 2010). The historical population density is based on data from the History Database of the Global Environment (Klein Goldewijk et al., 2017). The future scenario follows a middle-of-the-road shared socioeconomic pathway (SSP2, Jones and O'Neill, 2016). In our simulations the change in ignition rate is governed by the change in population density, as the number of flashes was kept constant. The ignition events in 2071-2100 relative to the reference period 1981-2010 are shown in Figure 4.7d. The population density is projected to increase in Norway and Sweden, while in Finland the 
development is close to neutral, and in Russia the trend is negative. The same development can therefore be seen in the ignition rates.

In SPITFIRE, fuel moisture controls the fire danger, the rate of spread and the completeness of combustion. In the model, fuel consists of litter that is divided into fuel classes based on the size of the fuel elements, such as leaves and twigs, small branches, large branches and trunks. The division based on size is used because a small fuel element has a large surface area-tovolume ratio, and therefore loses or gains moisture faster than a large fuel element (Thonicke et al., 2010).

The SPITFIRE model uses the Nesterov index to estimate the fuel moisture. The Nesterov index is a cumulative function of daily maximum and dew point temperature, and describes the drying during periods of consecutive days without precipitation (i.e. the drying power). The changes in the Nesterov index therefore reflect the combined effect of changes in temperature and precipitation shown in Figures 4.4 and 4.5. CanESM2 is the model with the highest increase in temperature by 2100 and also simulates the largest increase in the average drying power in the summer. CNRM-CM5 has the largest increase in precipitation and a modest increase in temperature by 2100 , and therefore simulates even a small decrease in the average drying power in the summer for some areas, mainly in southern parts of Finland and Sweden.

The temporal development of the fuel moisture is estimated from the Nesterov index by weighting the index with the amount of fuel in each of the fuel classes. The fuel classes consist of litter, except for the fuel class containing the smallest fuel elements, which also includes live biomass of herbaceous plants. The change in relative fuel moisture, i.e. the fuel-weighted Nesterov index, from 1981-2010 to 2071-2100 is shown in Figure 4.8. 
Change in relative fuel moisture under RCP4.5
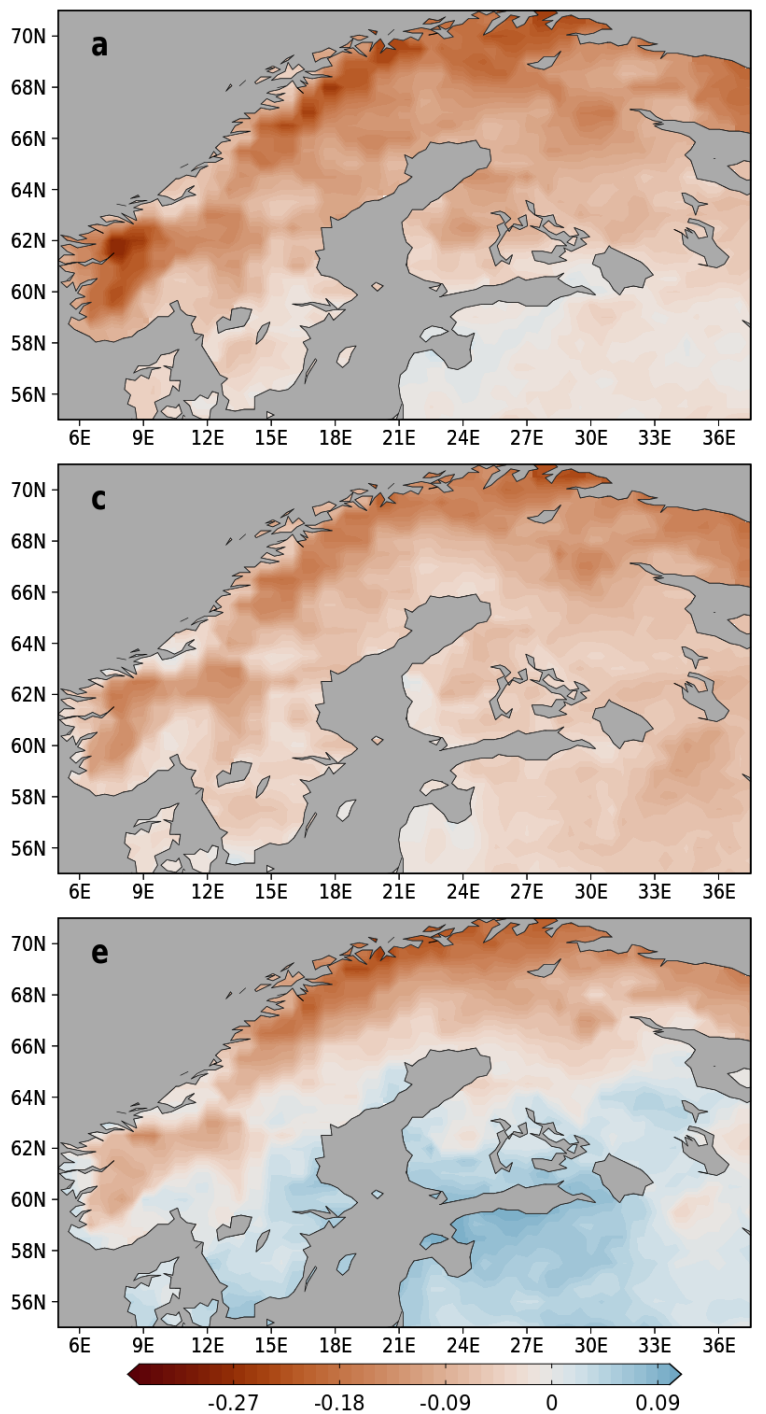

Change in relative fuel moisture under RCP8.5
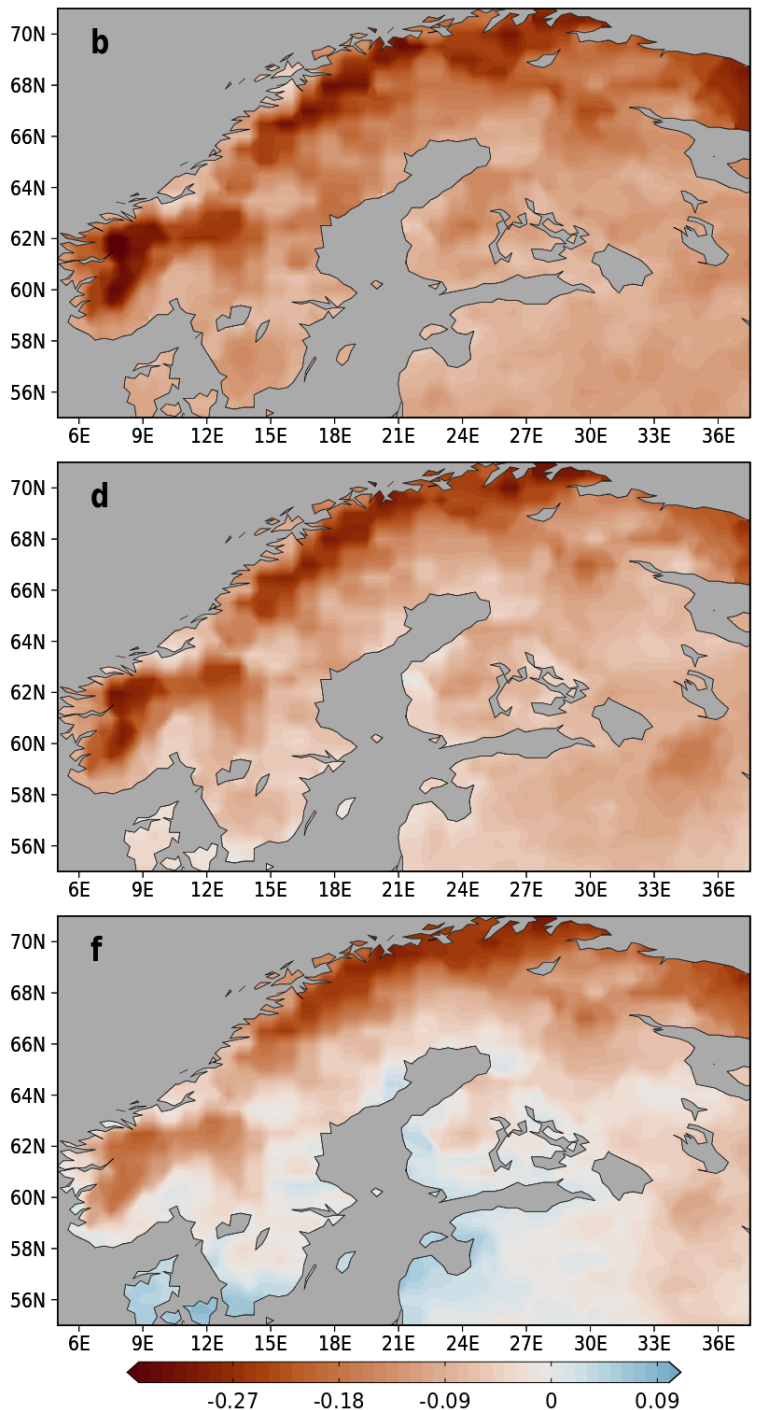

Figure 4.8. Projected change in relative fuel moisture (unitless, fuel-weighted Nesterov index) during summer months (JJA) from the period 1981-2010 to 2071-2100 under the RCP4.5 and RCP8.5 climate change scenarios. Red indicates drier fuel in the future. Results based on the global driver models CanESM2, MIROC5 and CNRM-CM5 are shown in the top, middle and bottom panels, respectively.

In general, the models simulate drier fuels for the future. The simulation driven by the CanESM2 data, which has the highest temperature increase, projects the largest reduction in the relative fuel moisture (Fig. 4.8a-b). The simulations driven by MIROC5 data even project a small increase in the moisture content of the fuels in southern Finland and Sweden under both RCP4.5 and RCP8.5, and the Republic of Karelia under RCP4.5 (Fig. 4.8e-f). The fuel drying in the mountainous regions are emphasised due to the low amount of woody litter in those regions (see Fig. 4.6) as the smallest fuel classes dry more readily than more substantial woody litter. 
The probability that an ignition event will start a fire is described by the fire danger index (FDI). The probability of a spreading fire goes to zero for wet fuel, increases linearly with decreasing litter moisture, and becomes unity for completely dry litter. The probability therefore depends on the fire weather conditions, which are expressed by the Nesterov Index. However, the changes in fire weather conditions are modulated by the litter composition, i.e. the size distribution of the fuel elements. Furthermore, the fire danger becomes zero if there is not enough fuel present. An example of the spatial distribution of FDI during the reference period 1981-2010 is shown in Figure 4.9. The projected changes in FDI from 1981-2010 to 20712100 are shown in Figure 4.10. The changes in FDI in general follow the changes seen in the relative fuel moisture in Figure 4.8. The probability that an ignition event will start a fire is projected to increase in most of the scenarios for Fennoscandia, especially under RCP8.5. However, the simulations based on data from CNRM-CM5 project a small decrease in FDI, especially under RCP4.5 for southern Sweden and Finland, and also in parts of the Republic of Karelia (Figure $4.10 \mathrm{e}-\mathrm{f}$ ). This model has the largest increase in precipitation and only a modest increase in temperature by 2100 .

Fire danger index 1981-2010

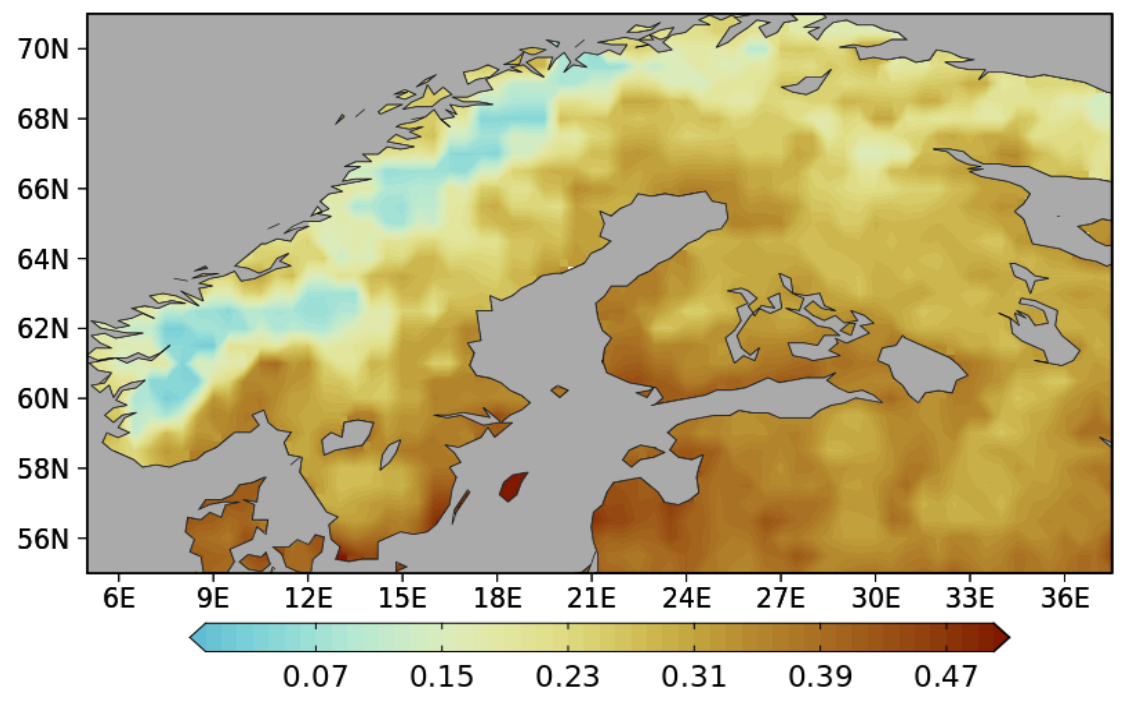

Figure 4.9. The fire danger index (unitless) for the reference period 1981-2010 based on data from MIROC5. 

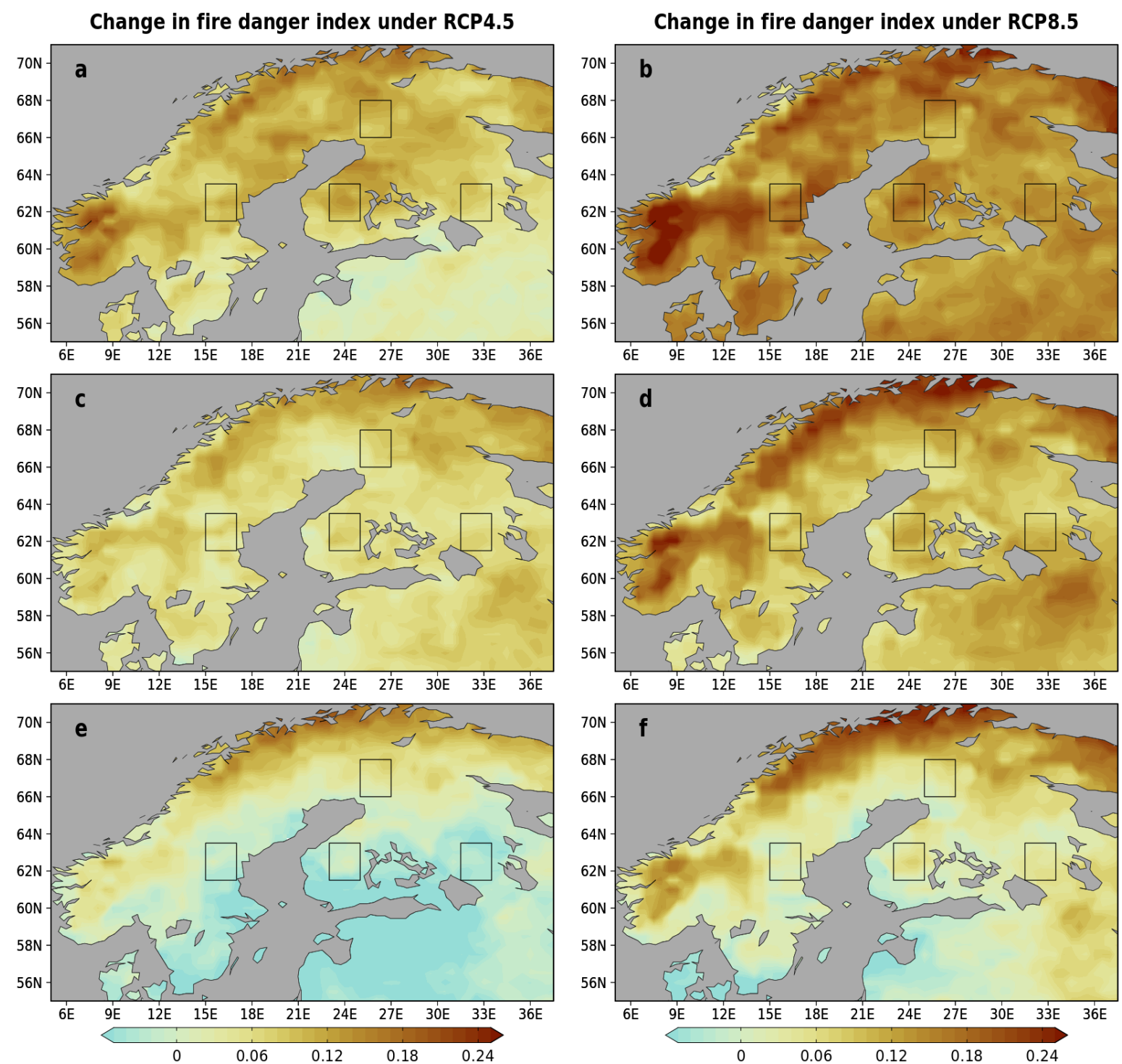

Figure 4.10. Projected change in FDI (unitless) during summer months (JJA) from the period 1981-2010 to 2071-2100 under the RCP4.5 and RCP8.5 climate change scenarios. Results based on the global driver models CanESM2, MIROC5 and CNRM-CM5 in the top, middle and bottom panels, respectively.

A more detailed view of the temporal development of FDI is given in Figure 4.11. The time series are given for the areas indicated by rectangles in Figure 4.10. The projected changes in FDI are quite similar for the selected regions. The projected changes in the temperature and precipitation (Figs. 4.4-4.5) and fuel moisture (Fig. 4.8) are reflected in the temporal development of FDI. The data based on the CanESM2 model gives the largest increase in the FDI and the data based on CNRM-CM5 gives only a minor change in FDI by 2100 . The projected FDI relative to 1981-2010 (Fig. 4.11) is 0.95-1.4 for southern Finland (a), ca. 1.151.4 for northern Finland (b), ca. $0.95-1.3$ for Sweden (c) and ca. $0.95-1.25$ for the Republic of Karelia (d) under RCP4.5. The respective ranges under RCP8.5 are ca. 1.15-1.55 (a), 1.151.55 (b), 1.05-1.6 (c) and 1.15-1.55 (d). It is worth noting that the FDI only describes the probability of fire if an ignition event occurs in a given area; it does not describe how many 
fires will occur. The ignition rate determines the maximum number of fires started in a location. Furthermore, the fuel availability and moisture will determine the severity of the fire.
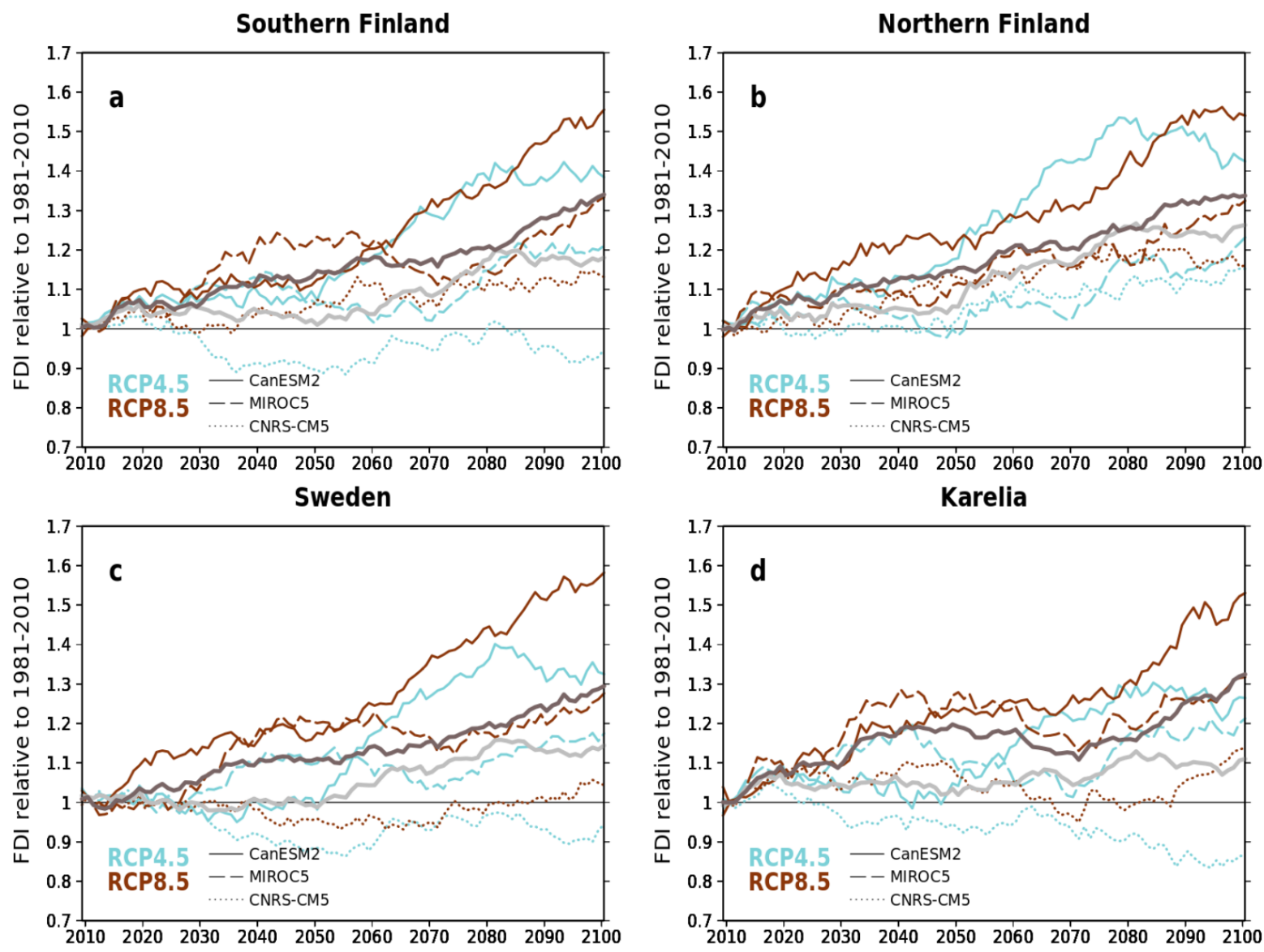

Figure 4.11. Relative change in projected FDI (unitless) during summer months (JJA) from the period 1981-2010 to 2071-2100. Time series are shown for the areas indicated by rectangles in Figure 4.10. Each panel shows the development under the RCP4.5 and RCP8.5 climate change scenarios based on data from the global driver models CanESM2 (continuous line), MIROC5 (dashed line) and CNRM-CM5 (dotted line). The ensemble means under the RCP4.5 and RCP8.5 are shown with light grey and dark grey lines, respectively.

\subsubsection{Future fire regimes in Fennoscandia}

In general terms, a fire regime describes the spatial and temporal pattern, and ecosystem impacts, of fire in an area and over a given time period. The most important factors for determining fire regimes are vegetation type and climate. The climate affects fire regimes directly through weather patterns, but also through its effect on vegetation composition.

The fire frequency, or the number of fires per unit area and time, is obtained from the product of the FDI (Fig. 4.9) and the ignition rate (Fig. 4.7d). The projected change in fire frequency from 1981-2010 to 2071-2100 is shown in Figure 4.12. Under the RCP4.5 climate change scenario JSBACH-SPITFIRE simulates a change in the fire frequency by the end of the century from -10 to $40 \%$ for the forested areas within the domain. The change under RCP8.5 is from 30 to $80 \%$. The changes in fuel moisture (Fig. 4.8) strongly affect the simulated occurrence of fires. The simulations forced by the CanESM2 derived data showed the strongest decrease in fuel moisture and hence the strongest increase in fire frequency. The projected moistening of 
the fuel in southern Finland and Sweden, and the Republic of Karelia (Fig. 4.8e-f) seen in the simulations forced by CNRM-CM5 derived data shows up as a decrease in the fire frequency (Fig. 4.12e-f). In addition, the fire frequency is projected to decrease in large parts of the Republic of Karelia due to the decreasing population density, and hence decreasing ignition rates (Fig. 4.7d). In the simulations with the largest temperature increase, this decrease in ignition rates is largely compensated by the stronger fuel drying power (Fig. 4.12b-d).
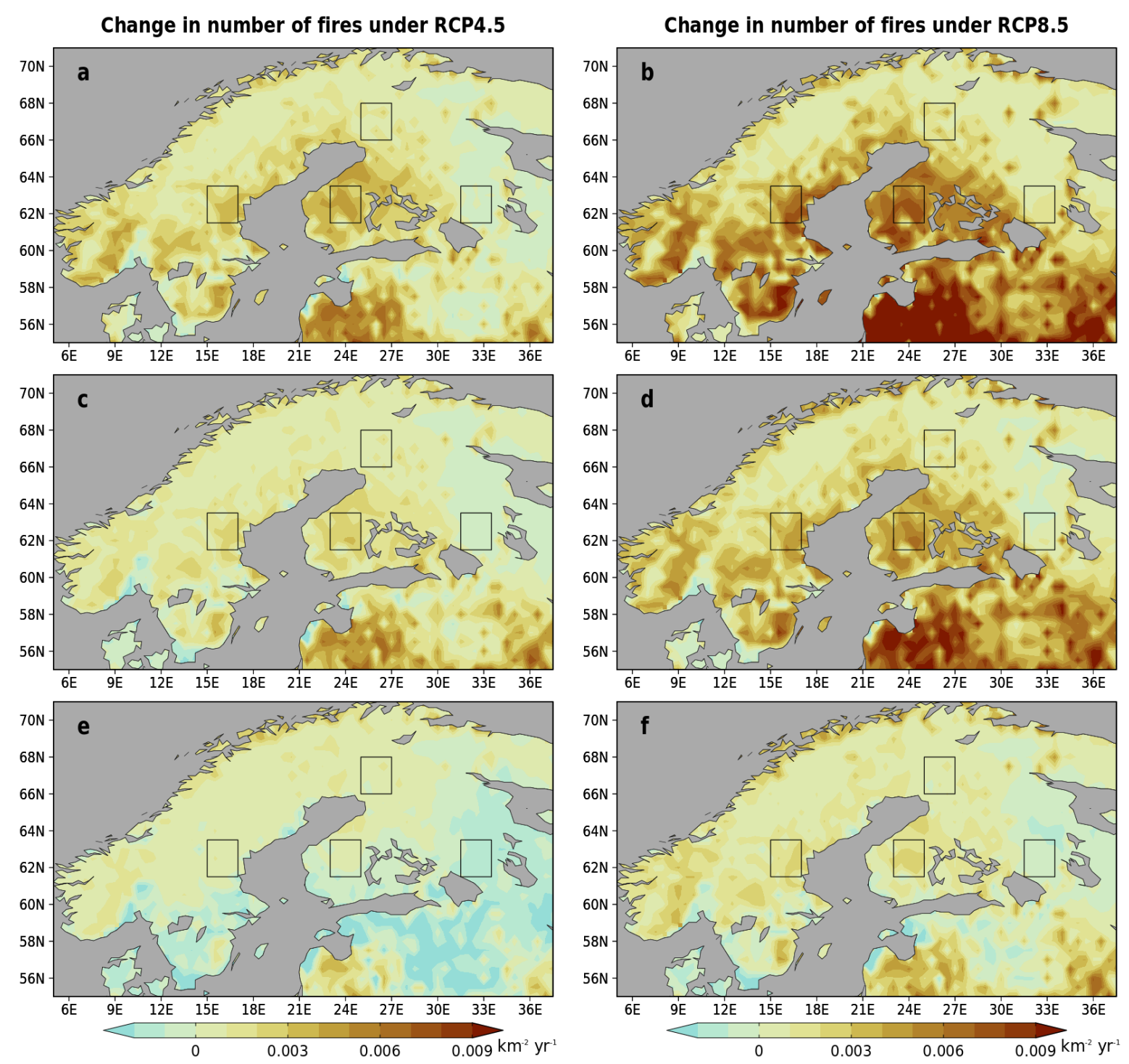

Figure 4.12. Projected change in the fire frequency $\left(\mathrm{yr}^{-1} \mathrm{~km}^{-2}\right)$ from the period 1981-2010 to 2071-2100 under the RCP4.5 and RCP8.5 climate change scenarios. Yellow and red indicate more frequent fires in the future. Results based on data from the global driver models CanESM2, MIROC5 and CNRM-CM5 in the top, middle and bottom panels, respectively.

The fire return interval (Fig. 4.13) is the inverse of the fire frequency. The fire return interval reflects the local ignition rate and the availability and properties of fuel. The changes in fire return interval from 2010 to 2100 are shown in Figure 4.2.11 as a time series for the areas indicated by rectangles in Figure 4.12. In general, climate change in Fennoscandia tends to decrease the fire return interval, as seen from the change in fire frequency in Figure 4.12. However, the projected decrease in population density for Russia causes the fire return time to either increase or remain almost unchanged (Fig. 4.14d). Only the simulations based on 
CanESM2 and MIROC5 data under RCP8.5 project a decrease in the fire return time for the Republic of Karelia, due to strong warming. The model averages for the Republic of Karelia give an increase in fire return interval of about 40 years under RCP4.5, and a decrease of about 15 years under RCP8.5 (grey lines in Fig. 4.14).

Fire return time 1981-2010

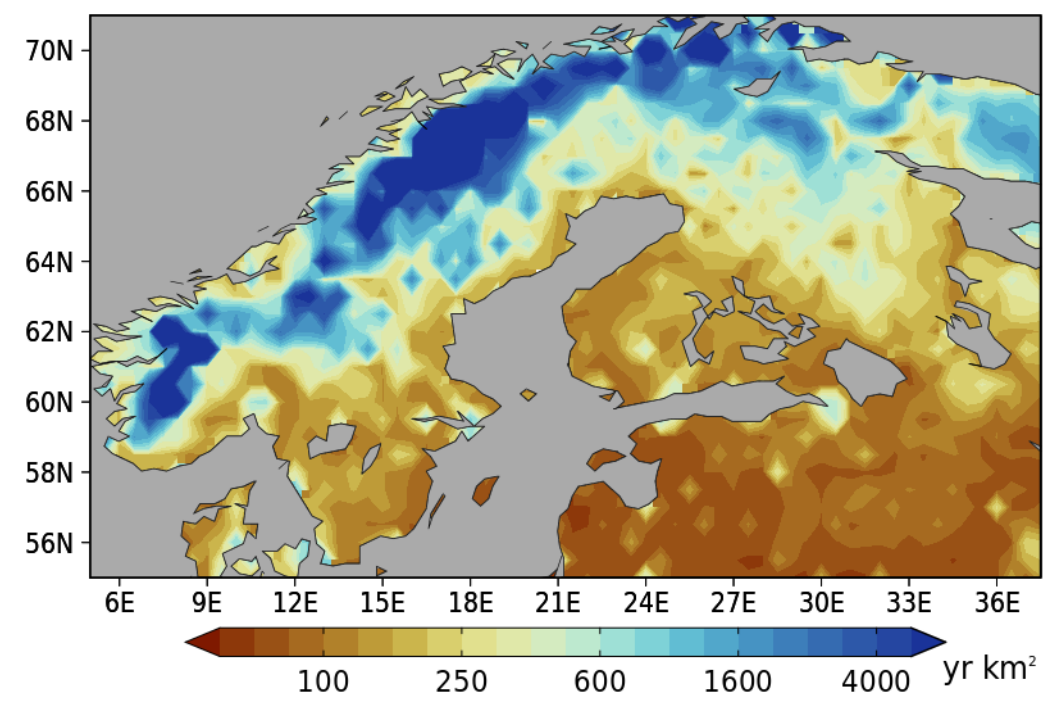

Figure 4.13. The fire return time $\left(\mathrm{yr} \mathrm{km}^{2}\right)$ for the reference period $1981-2010$ based on data from MIROC5.

The ignition rates are low in northern Finland compared to southern Finland. The model average for fire return interval during the reference period 1981-2010 is 155 and $380 \mathrm{yr} \mathrm{km}^{2}$ for southern and northern Finland, respectively. Some caution is advised when interpreting changes in fire return interval; areas with a large fire return interval will show a large increase, even with a modest increase in the fire frequency. This can be seen in the case of southern and northern Finland. The increase in fire frequency is smaller in northern Finland than in southern Finland (Fig. 4.12), while the decrease in fire return interval is larger in the north (Fig. 4.14ab). The areas in Sweden and Republic of Karelia in Figure 4.14c-d start out with similar fire return times during the reference period, 232 and $218 \mathrm{yr} \mathrm{km}^{2}$, respectively. Due to the decreasing ignition rates in the Republic of Karelia and increasing ignition rates in Sweden, the development in the fire return time is nearly opposite. The differences in the FDI are relatively small between these regions (Fig. 4.11c-d). 

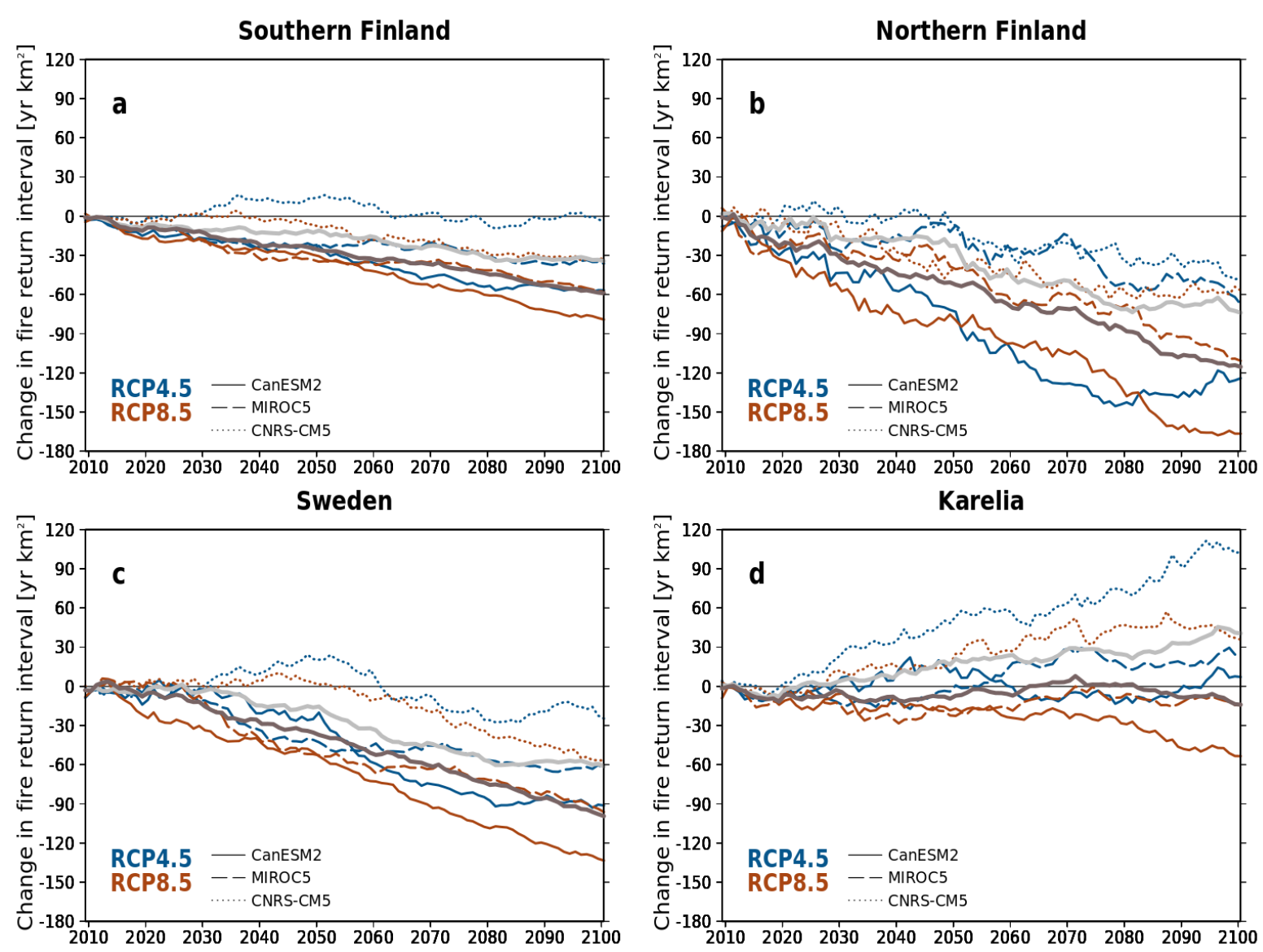

Figure 4.14. Projected change in fire return interval $\left(\mathrm{yr} \mathrm{km}^{2}\right)$ from the period 1981-2010 to 2071-2100. Time series are shown for the areas indicated by rectangles in Figure 4.12. Each panel shows the development under the RCP4.5 and RCP8.5 climate change scenarios based on data from the global driver models CanESM2 (continuous line), MIROC5 (dashed line) and CNRM-CM5 (dotted line). The ensemble means under the RCP4.5 and RCP8.5 are shown with light grey and dark grey lines, respectively.

The burnt area fraction depends on the fire frequency (Fig. 4.12) and the mean fire area, which in turn depends on the fuel load, composition and moisture. The features in the change of fire frequency can also be seen in the projected changes in burnt area fraction shown in Figure 4.15. It is worth noting that the burnt area fraction increases regardless of the projected decrease in woody above-ground litter (Fig. 4.7c). The decrease in the amount of litter is relatively small, and therefore the warming due to climate change can still cause an increase in burnt area through the increased fire danger (Fig. 4.10). However, in the simulations driven by CNRMCM5 data, which show the smallest temperature increases, the burnt area fraction is projected to decrease in some areas. This is especially the case under RCP4.5 for western Sweden, southern Finland and the Republic of Karelia. The decreasing ignition rates projected for Russia reduce the increase, or strengthens the decrease, for the burnt area fraction in the Republic of Karelia. 

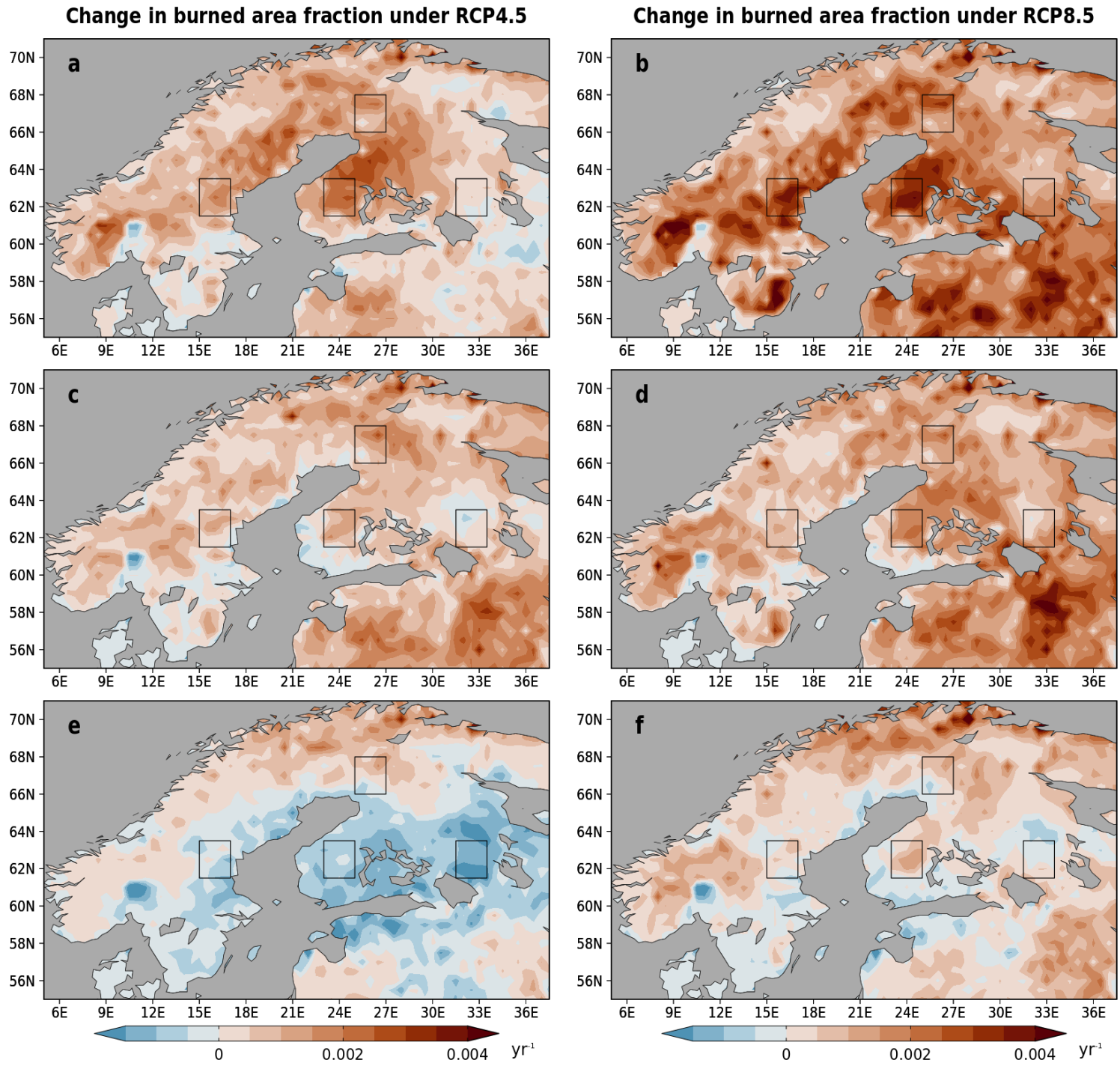

Figure 4.15. Projected change in the burnt area fraction $\left(\mathrm{yr}^{-1}\right)$ from the period $1981-2010$ to 2071-2100 under the RCP4.5 and RCP8.5 climate change scenarios. Red indicates larger burnt areas in the future. Results based on data from the global driver models CanESM2, MIROC5 and CNRM-CM5 in the top, middle and bottom panels, respectively.

The projected temporal development of the burnt area fraction relative to the reference period (1981-2010) is given as a time series in Figure 4.16 for the areas indicated by rectangles in Figure 4.15. The projected changes in burnt area are quite similar for southern Finland and Sweden, while the simulations show a smaller range for northern Finland. In these regions the burnt areas are projected to increase in all simulations, except in the simulation driven by data from CNRM-CM5 under RCP4.5 (Fig. 4.16a-c). The projected changes in the Republic of Karelia are smaller than for the other areas. The model average under RCP4.5 is even negative (Fig. 4.16d, light grey line), mostly due to the projected decreasing population density, and hence decreasing ignition rates. The projected burnt area relative to 1981-2010 (Fig. 4.16) is (a) 0.8-1.6 for southern Finland, (b) 1.1-1.4 for northern Finland, (c) 0.9-1.4 for Sweden and 
(d) $0.6-0.0$ for the Republic of Karelia under RCP4.5. The respective ranges under RCP8.5 are (a) 1.2-1.95, (b) 1.1-1.6, (c) 0.0-1.9 and (d) 0.0-1.4.
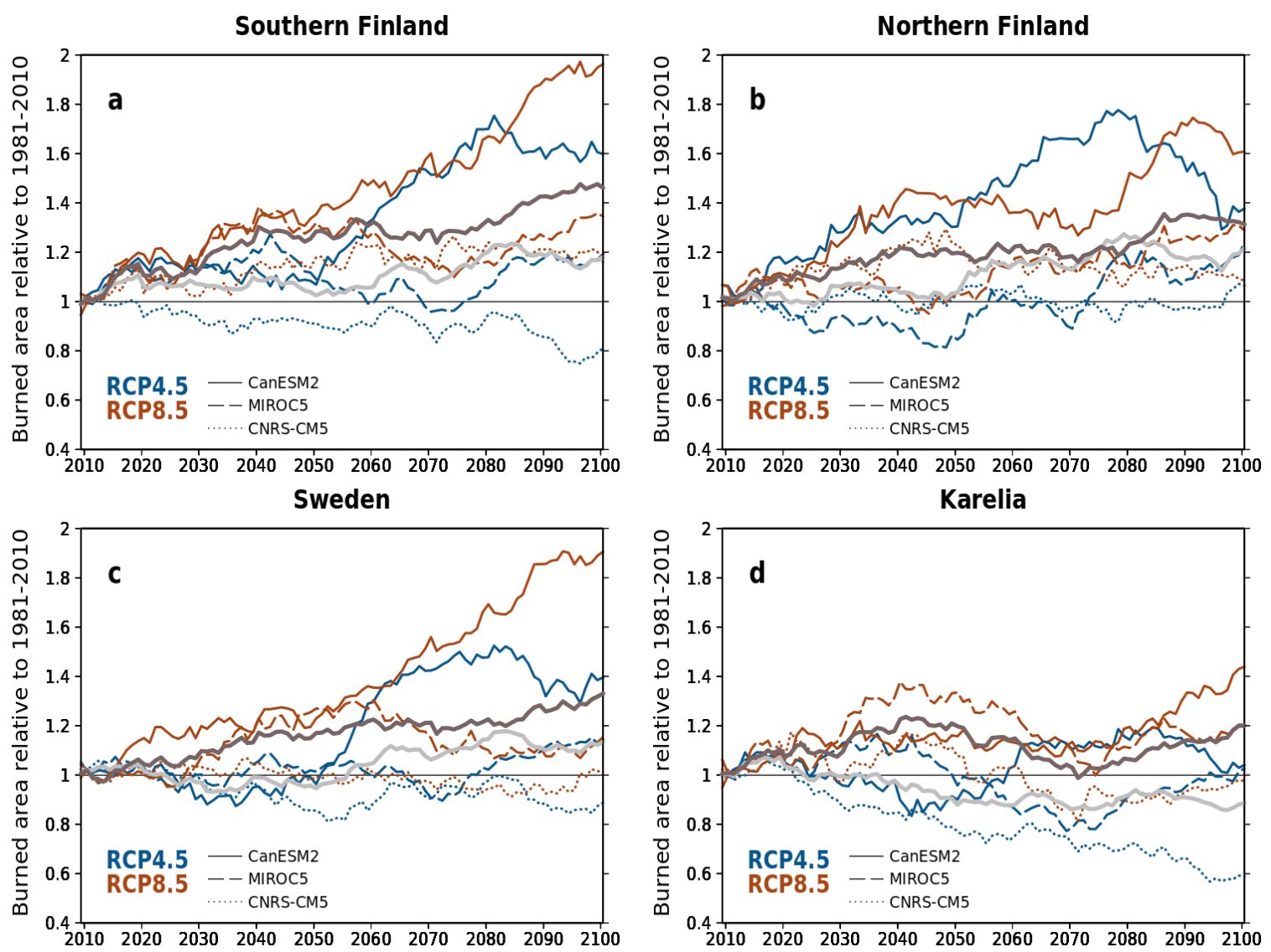

Figure 4.16. Projected change in burnt area fraction $\left(\mathrm{yr}^{-1}\right)$ from the period 1981-2010 to 20712100. Time series are shown for the areas indicated by rectangles in Figure 4.15. Each panel shows the development under the RCP4.5 and RCP8.5 climate change scenarios based on data from the global driver models CanESM2 (continuous line), MIROC5 (dashed line) and CNRMCM5 (dotted line). The ensemble means under the RCP4.5 and RCP8.5 are shown with light grey and dark grey lines, respectively.

The projected change in $\mathrm{CO}_{2}$ flux from fires are shown in Figure 4.17 for the areas indicated by rectangles in Figure 4.15. The temporal development in the $\mathrm{CO}_{2}$ flux is very similar to the development in burnt area fraction, which is expected as the amount of $\mathrm{CO}_{2}$ that is emitted depends on the amount of burnt litter and live biomass. However, the amount of biomass is not uniform and the moisture content of the fuel will affect the intensity of the fire. With dry fuel the intensity will be higher, and the completeness of combustion will be higher. A high intensity fire will also cause more damage to the live biomass. 

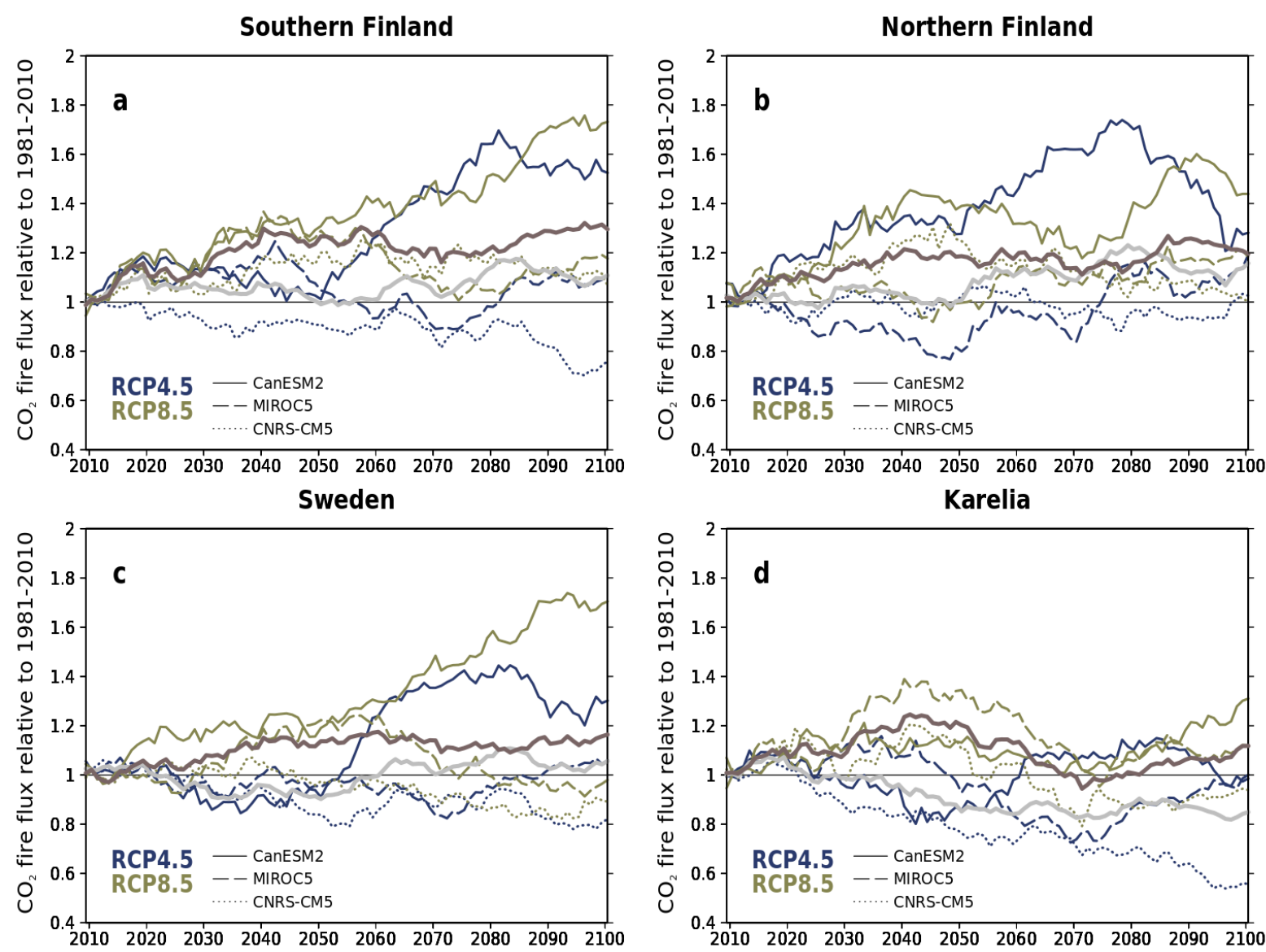

Figure 4.17. Relative change in projected fire carbon flux (unitless) from the period 19812010 to 2071-2100. Time series are shown for the areas indicated by rectangles in Figure 4.15. Each panel shows the development under the RCP4.5 and RCP8.5 climate change scenarios based on data from the global driver models CanESM2 (continuous line), MIROC5 (dashed line) and CNRM-CM5 (dotted line). The ensemble means under the RCP4.5 and RCP8.5 are shown with light grey and dark grey lines, respectively.

The simulations with JSBACH-SPITFIRE were done using the current land cover of Fennoscandia. In order to test the effect of changing land use due to climate change, a simulation was performed with the LPJ-GUESS model (Smith et al., 2014), which uses the Glob-FIRM model (Thonicke et al., 2001) to simulate fires. The simulation was forced by the CanESM2 RCP4.5 derived data. The simulation was made with the LPJ-GUESS in a mode where trees grow from seedlings to mature trees, and plant species thrive by competition starting from grasses immediately after the fire. In the simulation the forests were naturally regenerating and unmanaged, resulting in an increase in Norway spruce and broadleaved deciduous trees, mainly birch and ash. The changes in fire return interval follow the changes in temperature and precipitation of the driver data, in addition the changes in land use modulate the results. The fire activity is somewhat suppressed in the areas where the fraction of deciduous trees increases, mostly in southern Sweden and Finland.

\subsubsection{Forest management influences on fire risk}

The effect of forest management on future fire risk and fire regimes was studied for two sites, representing climatic conditions for central and northern Finland, under climate change scenarios RCP4.5 and RCP8.5 for the period 2010-2054. The simulations for the two sites were 
forced with downscaled and bias-corrected data from EURO-CORDEX (Jacob et al., 2014). In total, 36 cases were simulated, considering two sites with three owner types, with forcing from three driver models under two climate change scenarios. The same driver data was used as in the simulation for Fennoscandia, described in chapter 4.2.1.

The simulations were performed in two stages, first the harvest scenarios were simulated using a version of the JSBACH land surface model that includes forest management, JSBACH-FOM (Naudts et al., 2021). These results were then used as input for the JSBACH-SPITFIRE (Thonicke et al., 2010; Lasslop et al., 2014), in order to simulate the effect of forest harvesting intensity on forest fires. The JSBACH-FOM was set up to simulate pine forests managed according to prescribed harvest scenarios. The pine forest growth parameters were derived from allometric relationships by Marklund (1988) and the self-thinning parameterisation by Hynynen (1993).

The forest harvest scenarios had been derived in accordance with the national energy and climate strategy for 2030 (Huttunen, 2017). The harvest scenarios cover the period from 2010 to 2054. The scenarios represent three different forest owner types, with different emphases on economical values and carbon sequestration. The represented owner types with corresponding harvest scenarios can be described as: an owner focused on the output with high cutting shares with relatively short rotation lengths; a middle-of-the-road owner with moderate cuttings and rotation; and an owner emphasising carbon stocks with cuttings at relatively high rotation lengths. The simulation setup also included a no-harvest option for each case. The harvesting scenarios also consider the different rates of forest growth at the studied sites. These factors result in different intensity of forest harvesting, and subsequently a varying age distribution of the forest at the sites. Another consequence is the impact on the amount of above-ground litter: the amount of litter increases with harvesting intensity in the model.

Enough fuel needs to be present in order for an ignition event to develop into a spreading fire, and the fuel also needs to be dry enough. The climate and ignition rates are not affected by the harvest intensity in the simulations. In the simulated cases the availability of litter does not limit the spreading following an ignition event, i.e. the fire frequency is not affected by the forest management in the simulations. However, the area burnt, and the fire intensity is affected, because they depend on the available above-ground litter. The fuel moisture content is mostly affected by the climate forcing data, while the amount of litter only has a small impact. Overall, the climate conditions are more important for determining the fire risk than the forest management in the simulations. However, climate models used here are not detailed enough to account for all of the factors that contribute to the fire risk and fire regimes in managed forests, such as site preparation, as described below. In these simulations the main effect from forest management is through the amount of fuel due to logging slash. During the studied time period (2010-2054) no clear trend is seen in fire frequency at the simulated sites.

In Fennoscandia, forest-type classification is based largely on understorey vegetation. Understorey vegetation, its moisture variation, as well as dead fine fuels and their drying process largely affect the ignition risk. Practically all forest stands are classified according to their vegetation, and stand characteristics information include information on site type, age/development class, tree species and stand structure. All these variables affect fire risk and based on this information forests have been classified according to their fire risk (ignition, flammability, crown fire risk) (Lindberg et al., 2011). 
Understorey vegetation, lichens, pleurocarpous mosses and dead grasses (especially in spring) dry quickly (and are sometimes therefore called flash fuels) and have high ignition risk (Lindberg et al., 2021). Fine fuels also include logging slash, formed in intermediate and final fellings, and if not removed after felling operations for bioenergy, increase local- and landscape-level as well as regional fire risk. As approximately $90 \%$ of forests in Finland are production forests, where fellings are performed on a regular basis, forest management can be estimated to have a high importance on fire risk. Also site preparation, which is often used after final fellings, increases ignition risk, especially if carried out by disc trenching. According to a recent study (Sjöström and Granström, 2020), all machinery operations increase ignition risk significantly. More accurate information on forest management operations and their effect on the amount of fine fuels in particular would probably increase the accuracy of the models.

\section{References}

Cecil, D.J., 2015. LIS/OTD Gridded Lightning Climatology Data Collection. Data set available online (https://ghrc.nsstc.nasa.gov/pub/lis/climatology/) from the NASA EOSDIS Global Hydrology Resource Center Distributed Active Archive Center Huntsville, Alabama, U.S.A.

Collins, M., Knutti, R., Arblaster, J., Dufresne, J.-L., Fichefet, T., Friedlingstein, P., Gao, X., Gutowski, W. J., Johns, T., Krinner, G., Shongwe, M., Tebaldi, C., Weaver, A. J., Wehner, M. 2013. Long-term Climate Change: Projections, Commitments and Irreversibility. In: Climate Change 2013: The Physical Science Basis. Contribution of Working Group I to the Fifth Assessment Report of the Intergovernmental Panel on Climate Change [Stocker, T. F., Qin, D., Plattner, G.-K., Tignor, M., Allen, S. K., Boschung, J., Nauels, A., Xia, Y., Bex, V., Midgley, P.M. (eds.)]. Cambridge University Press, Cambridge, United Kingdom and New York, NY, USA.

Dai, A., Luo, D., Song, M., Liu, J. 2019. Arctic amplification is caused by sea-ice loss under increasing $\mathrm{CO}_{2}$. Nature Communications 10: 121.

de Groot, W.J., Flannigan, M.D., Cantin, A.S. 2013. Climate change impacts on future boreal fire regimes. Forest Ecology and Management 294: 35-44.

Ditas, J., Ma, N., Zhang, Y., Assmann, D., Neumaier, M., Riede, H., Karu, E., Williams, J., Scharffe, D., Wang, Q., Saturno, J., Schwarz, J.P., Katich, J.M., McMeeking, G.R., Zahn, A., Hermann, M., Brenninkmeijer, C.A.M., Andreae, M.O., Pöschl, U., Su, H., Cheng, Y. 2018. Strong impact of wildfires on the abundance and aging of black carbon in the lowermost stratosphere. Proceedings of the National Academy of Sciences of the United States of America 115: E11595-E11603.

European Environment Agency (EEA). 2020. Corine Land Cover (CLC) 2012, Version 2020_20u1, (accessed 2020, Jun 12). https://land.copernicus.eu/pan-european/corine-landcover/clc-2012

European Space Agency. 2019. Land cover classification gridded maps from 1992 to present derived from satellite observations, Copernicus Climate Data Store, (accessed 2020, Mar 30) https://cds.climate.copernicus.eu/cdsapp\#!/dataset/satellite-land-cover

Flannigan, M.D., Bergeron, Y., Engelmark, O., Wotton, B.M. 1998. Future wildfire in circumboreal forests in relation to global warming. Journal of Vegetation Science 9: 469476.

Flannigan, M.D., Stocks, B.J., Wotton, B.M. 2000. Climate change and forest fires. Science of the Total Environment 262: 221-229.

Flannigan, M.D., Amiro, B.D., Logan, K.A., Stocks, B.J., Wotton, B.M. 2005a. Forest fires and climate change in the $21^{\text {st }}$ century. Mitigation and Adaptation Strategies for Global Change 11: 847-859. 
Flannigan, M.D., Logan, K.A., Amiro, B.D., Skinner, W.R., Stocks, B.J., 2005b. Future area burned in Canada. Climatic Change 72: 1-16.

Flannigan, M.D., Stocks, B.J., Turetsky, M., Wotton, B.M. 2009. Impacts of climate change on fire activity and fire management in circumboreal forest. Global Change Biology 15: 549560 .

Huttunen R. (Ed)., 2017. Government report on the National Energy and Climate Strategy for 2030. Publications of the Ministry of Economic Affairs and Employment 12/2017. 121 pp. http://urn.fi/URN:ISBN:978-952-327-199-9

Hynynen, J. 1993. Self-thinning models for even-aged stands of Pinus sylvestris, Picea abies and Betula pendula, Scandinavian Journal of Forest Research 8: 326-336.

Groenemeijer, P., Vajda, A., Lehtonen, I., Kämäräinen, M., Venäläinen, A., Gregow, H., Becker, N., Nissen, K., Ulbrich, U., Nápoles O.M., Paprotny, D., Púčik, T. 2016. Present and future probability of meteorological and hydrological hazards in Europe RAIN - Risk analysis of infrastructure networks in response to extreme weather. Wessling, Germany: ESSL, 45 pp.

IPCC, 2013. Climate Change 2013: The Physical Science Basis. Contribution of Working Group I to the Fifth Assessment Report of the Intergovernmental Panel on Climate Change [Stocker, T.F., Qin, D., Plattner, G.-K., Tignor, M., Allen, S.K., Boschung, J., Nauels, A., Xia, Y., Bex, V., Midgley, P.M. (eds.)]. Cambridge University Press, Cambridge, United Kingdom and New York, NY, USA, 1535 pp.

Jacob, D., Petersen, J., Eggert, B., Alias, A., Christensen, O.B., Bouwer, L.M., Braun, A., Colette, A., Déqué, M., Georgievski, G., Georgopoulou, E., Gobiet, A., Menut, L., Nikulin, G., Haensler, A., Hempelmann, N., Jones, C., Keuler, K., Kovats, S., Kröner, N., Kotlarski, S., Kriegsmann, A., Martin, E., van Meijgaard, E., Moseley, C., Pfeifer, S., Preuschmann, S., Radermacher, C., Radtke, K., Rechid, D.,Rounsevell, M., Samuelsson, P., Somot, S., Soussana, J.-F., Teichmann, C., Valentini, R., Vautard, R., Weber, B., Yiou, P. 2014. EURO-CORDEX: new high-resolution climate change projections for European impact research. Regional environmental change 14: 563-578.

Jones, B., O'Neill, B.C. 2016. Global One-Eighth Degree Population Base Year and Projection Grids Based on the Shared Socioeconomic Pathways, Revision 01. Palisades, NY: NASA Socioeconomic Data and Applications Center (SEDAC). https://doi.org/10.7927/m30pj498. Accessed May 18, 2020.

Kaminski, T., Knorr, W., Schürmann, G., Scholze, M., Rayner, P.J., Zaehle, S., Blessing, S., Dorigo, W., Gayler, V., Giering, R., Gobron, N., Grant, J.P., Heimann, M., Hooker-Stroud, A., Houweling, S., Kato, T., Kattge, J., Kelley, D., Kemp, S., Koffi, E.N., Köstler, C., Mathieu, P.-P., Pinty, B., Reick, C. H., Rödenbeck, C., Schnur, R., Scipal, K., Sebald, C., Stacke, T., Terwisscha van Scheltinga, A., Vossbeck, M., Widmann, H., Ziehn, T. 2013. The BETHY/JSBACH Carbon Cycle Data Assimilation System: experiences and challenges. Journal of Geophysical Research: Biogeosciences 118: 1414-1426.

Ketola, J., 2018. Hevonkuusessa palaa isosti - Tilastollinen selvitys kesän 2018 metsäpalojen leviämisestä. Pelastusopisto, Kuopio, $83 \mathrm{p}$. [There is a big fire in the middle of nowhere Statistical report on the spread of forest fires in the summer of 2018. Emergency Services Academy Finland. [In Finnish].]

Kilpeläinen, A., Kellomäki, S., Strandman, H., Venäläinen, A. 2010. Climate change impacts on forest fire potential in boreal conditions in Finland. Climatic Change 103: 383-398.

Klein Goldewijk, K., Beusen, A., Doelman, J,. Stehfest, E. 2017. Anthropogenic land use estimates for the Holocene; HYDE 3.2. Earth System Science Data 9: 927-953.

Krikken, F., Lehner, F., Haustein, K., Drobyshev, I., van Oldenborgh, G. J. 2019. Attribution of the role of climate change in the forest fires in Sweden in 2018. Natural Hazards and Earth System Sciences Discussions 1-24. 
Lasslop, G., Thonicke, K., Kloster, S. 2014. SPITFIRE within the MPI Earth system model: Model development and evaluation. Journal of Advances in Modeling Earth Systems 6: 740 755.

Lehtonen, I., Ruosteenoja, K., Jylhä, K. 2014a. Projected changes in European extreme precipitation indices on the basis of global and regional climate model ensembles. International Journal of Climatology 34: 1208-1222.

Lehtonen, I., Ruosteenoja, K., Venäläinen, A., Gregow, H. 2014b. The projected $21^{\text {st }}$ century forest-fire risk in Finland under different greenhouse gas scenarios. Boreal Environment Research 19: 127-139.

Lehtonen, I., Venäläinen, A., Kämäräinen, M., Peltola, H., Gregow, H. 2016. Risk of largescale fires in boreal forests of Finland under changing climate. Natural Hazards and Earth System Sciences 16: 239-253.

Lehtonen, I., Venäläinen, A., 2020. Metsäpalokesä 2018 muuttuvassa ilmastossa poikkeuksellinen vuosi vai uusi normaali? Ilmatieteen laitos, Raportteja 2020:2, 26 p + Appendix. [Forest fire season 2018 in a changing climate - an exceptional year or new normal? Finnish Meteorological Institute Reports [in Finnish with abstract in English].]

Lindberg, H., Heikkilä, T. V., Vanha-Majamaa, I. 2011. Suomen metsien paloainekset - kohti parempaa tulen hallintaa. Metsäntutkimuslaitos, Vantaa, $104 \mathrm{pp}$. [Finnish forest fuels towards improved fire management [In Finnish with summary in English].]

Lindberg, H., Aakala, T., Vanha-Majamaa, I. 2021. Moisture content variation of ground vegetation fuels in boreal mesic and sub-xeric mineral soil forests in Finland. International Journal of Wildland Fire 30: 283-293.

Manning, C., Widmann, M., Bevacqua, E., Van Loon, A.F., Maraun, D., Vrac, M., 2019. Increased probability of compound long-duration dry and hot events in Europe during summer (1950-2013). Environmental Research Letters 14: 094006.

Marklund, L.G. 1988. Biomassafunktioner för tall, gran och björk i Sverige: biomass functions for pine, spruce and birch in Sweden, Sveriges lantbruksuniversitet, Institutionen för skogstaxering. Umeå, 73 pp.

Mauritsen, T., Bader, J., Becker, T., Behrens, J., Bittner, M., Brokopf, R., Brovkin, V., Claussen, M., Crueger, T., Esch, M., Fast, I., Fiedler, S., Fläschner, D., Gayler, V., Giorgetta, M., Goll, D.S., Haak, H., Hagemann, S., Hedemann, C., Hohenegger, C., Ilyina, T., Jahns,265T., Jimenéz-de-la Cuesta, D., Jungclaus, J., Kleinen, T., Kloster, S., Kracher, D., Kinne, S., Kleberg, D., Lasslop, G., Kornblueh, L.,Marotzke, J., Matei, D., Meraner, K., Mikolajewicz, U., Modali, K., Möbis, B., Müller, W.A., Nabel, J.E.M.S., Nam, C.C.W., Notz, D., Nyawira, S.-S., Paulsen, H., Peters, K., Pincus, R., Pohlmann, H., Pongratz, J., Popp, M., Raddatz, T. J., Rast, S., Redler, R., Reick,C. H., Rohrschneider, T., Schemann, V., Schmidt, H., Schnur, R., Schulzweida, U., Six, K. D., Stein, L., Stemmler, I., Stevens, B., von Storch, J.-S., Tian, F., Voigt, A., Vrese, P., Wieners, K.-H., Wilkenskjeld, S., Winkler, A., Roeckner, E. 2019. Developments in the MPI-M270Earth System Model version 1.2 (MPI-ESM1.2) and Its Response to Increasing $\mathrm{CO}_{2}$. Journal of Advances in Modeling Earth Systems 11: 998-1038.

Migliavacca, M., Dosio, A., Camia, A., Hobourg, R., Houston-Durrant, T., Kaiser, J.W., Khabarov, N., Krasovskii, A.A., Marcolla, B., San-Miguel-Ayanz, J., Ward, D.S., Cescatti, A. 2013. Modeling biomass burning and related carbon emissions during the 21 st century in Europe. Journal of Geophysical Research: Biogeosciences 118: 1732-1747.

Mäkelä, A., Enno, S.-V., Haapalainen, J. 2014a. Nordic lightning information system: Thunderstorm climate of Northern Europe for the period 2002-2011. Atmospheric Research 139: 46-61.

Mäkelä, H.M., Venäläinen, A., Jylhä, K., Lehtonen, I., Gregow, H. 2014b. Probabilistic projections of climatological forest fire danger in Finland. Climate Research 60: 73-85. 
Mäkelä, J., Minunno, F., Aalto, T., Mäkelä, A., Markkanen, T., Peltoniemi, M. 2020. Sensitivity of $21^{\text {st }}$ century simulated ecosystem indicators to model parameters, prescribed climate drivers, RCP scenarios and forest management actions for two Finnish boreal forest sites. Biogeosciences 17: 2681-2700.

Naudts, K., Nabel, J.E.M.S., Sabot, M., Pongratz, J. 2021. Impact of age-dependent wood harvest on land surface properties, in preparation.

Ruosteenoja, K., Jylhä, K., Kämäräinen, M. 2016. Climate projections for Finland under the RCP forcing scenarios. Geophysica 51: 17-50.

Ruosteenoja, K., Markkanen, T., Venäläinen, A., Räisänen, P., Peltola, H. 2018. Seasonal soil moisture and drought occurrence in Europe in CMIP5 projections for the $21^{\text {st }}$ century. Climate Dynamics 50: 1177-1192.

Räisänen, J., Ylhäisi, J.S. 2015. CO2-induced climate change in northern Europe: CMIP2 versus CMIP3 versus CMIP5. Climate Dynamics 45: 1877-1897.

Samuelsson, P., Jones, C.G., Willén, U., Ullerstig, A., Gollvik, S., Hansson, U., Jansson, C., Kjellström, E., Nikulin, G., Wyser, K. 2011., The Rossby Centre Regional Climate Model RCA3: model description and performance. Tellus A 63: 4-23.

Sanderson, B.M., O’Neill, B.C., Tebaldi, C. 2016. What would it take to achieve the Paris temperature targets? Geophysical Research Letters 43: 7133-7142.

Serreze, M. C., Barry, R.G. 2011. Processes and impacts of Arctic amplification: a research synthesis. Global and Planetary Change 77: 85-96.

Sherstyukov, B.G., Sherstyukov, A.B. 2014. Assessment of increase in forest fire risk in Russia till the late 21 st century based on scenario experiments with fifth-generation climate models. Russian Meteorology and Hydrology 39: 292-301.

Shvidenko, A.Z., Schepaschenko, D.G. 2013. Climate change and wildfires in Russia. Contemporary Problems of Ecology 6: 683-692.

Sjöström, J., Granström, A. 2020. Wildfires in Sweden - trends and patterns during recent decades. MSB Swedish Civil Contingencies Agency, Karlstad, 104 pp. [in Swedish with abstract in English].

Smith, B., Wårlind, D., Arneth, A., Hickler, T., Leadley, P., Siltberg, J., Zaehle, S. 2014. Implications of incorporating $\mathrm{N}$ cycling and $\mathrm{N}$ limitations on primary production in an individual-based dynamic vegetation model. Biogeosciences 11, 2027-2054.

Spinoni, J., Vogt, J., Naumann, G., Barbosa, P., and Dosio, A. 2018. Will drought events become more frequent and severe in Europe? International Journal of Climatology 38: 1718-1736.

Stocks, B.J., Fosberg, M.A., Lynham, T.J., Mearns, L., Wotton, B.M., Yang, Q., Jin, J.-Z., Lawrence, K., Hartley, G.R., Mason, J.A., McKenney, D.W. 1998. Climate change and forest fire potential in Russian and Canadian boreal forests. Climatic Change 38: 1-13.

Thonicke, K., Venevsky, S., Sitch, S., Cramer, W. 2001. The Role of Fire Disturbance for Global Vegetation Dynamics: Coupling Fire into a Dynamic Global Vegetation Model. Global Ecology and Biogeography 10: 661-677.

Thonicke, K., Spessa, A., Prentice, I.C., Harrison, S.P., Dong, L., Carmona-Moreno, C. 2010. The influence of vegetation, fire spread and fire behaviour on biomass burning and trace gas emissions: results from a process-based model. Biogeosciences 7: 1991-2011.

van Vuuren, D.P., Edmonds, J., Kainuma, M., Riahi, K., Thomson, A., Hibbard, K., Hurtt, G. C., Kram, T., Krey, V., Lamarque, J.F., Masui, T., Meinshausen, M., Nakicenovic, N., Smith, S.J., Rose, S.K. 2011. The representative concentration pathways: an overview. Climatic Change 109: 5-31.

Wotton, B.M., Nock, C.A., Flannigan, M.D. 2010: Forest fire occurrence and climate change in Canada. International Journal of Wildland Fire 19: 253-271. 
Yang, W., Andréasson, J., Graham, L.P., Olsson, J., Rosberg, J., Wetterhall, F. 2010. Distribution-based scaling to improve usability of regional climate model projections for hydrological climate change impact studies. Hydrological Research 41: 211-229.

Yang, W., Gardelin, M., Olsson, J., Bosshard, T. 2015. Multi-variable bias correction: Application of forest fire risk in present and future climate in Sweden. Natural Hazards and Earth System Sciences 15: 2037-2057. 


\section{Damages caused by forest fires can be reduced with technology, services, and community readiness}

Ari Venäläinen, Joonas Kolstela, Mikael Kukkonen, Päivi Mäkelä, Jarno Ruusunen, Timo Virtanen

The efficient mitigation of forest fires necessitates close cooperation between several organisations. Forest researchers and organisations produce forest inventory data needed in forest fire fuel assessments. Meteorological services produce viable information about forest fire danger (fire weather), fire spreading modelling, and also contribute to fire detection from satellites. Rescue services are responsible for fire extinguishing. As a whole, coordinated efforts in technology, services and community readiness will lead to best results when aiming at minimising the negative impacts of forest fires (Fig. 5.1).

\section{Damage caused by forest fires can be reduced with new technology, services, and community readiness}



Figure 5.1. Infographic 'Damage caused by forest fires can be reduced with new technology, services, and community readiness' summarizing the main concepts of the chapter.

\subsection{Fire detection and modelling helps rescue services to fight forest fires}

\subsubsection{Forest fire risk indices describe the potential for dangerous fires}

The assessment of forest fire risk is needed by rescue services in order to be prepared for fires. The ignition of fires, likewise the spread of fires, is largely dependent on weather conditions. Prolonged drought makes fuels dry and easily flammable, and once fire for one reason or 
another is ignited, it can spread easily. In order to be able to increase the preparedness of firefighting activities, there has to be a system to systematically rate the fire risk and its temporal and spatial variation. In this framework, different approaches have been developed for determining fire risk, using different variables and timescales. Fire risk indices determine the probability of fire ignition and the expectancy of fire spread. These indices are computed from weather variables, like air temperature, air humidity, precipitation and wind speed (SanMiguel-Ayanz et al., 2003; Matthews, 2009).

A large number of fire risk-rating systems are used around the world. These include the National Fire Danger Rating System (NFDRS) applied in the United States (Deeming et al., 1977; Bradshaw et al., 1983), the Nesterov index used in Russia (Nesterov, 1949), the Australian McArthur Forest Fire Danger Index (Dowdy et al., 2009) and Spanish and Italian wildfire risk assessment systems (San-Miguel-Ayanz et al., 2003; Fiorucci et al., 2008). Nevertheless, the most widely used fire risk evaluation system in Europe and North America is probably the Canadian Forest Fire Danger Rating System (CFFDRS) designed in the late 1960s (Turner and Lawson, 1978; Van Wagner, 1987). This calculation scheme was initially designed for Canadian boreal conditions, but it has been successfully adopted in other boreal forest environments and even in the Mediterranean region (Dimitrakopoulos et al., 2011; Padilla and Vega-Garcia, 2011), for example. It has also been used in the estimation of fire risk within the European Forest Fire Risk Forecast System (San-Miguel-Ayanz et al., 2012).

In Finland, the Finnish Meteorological Institute (FMI) operationally monitors fire risk, and issues public forest fire warnings when fire risk is high. Since summer 1996, the estimation of forest fire risk in Finland has been performed using the Finnish Forest Fire Index (FFI) (Heikinheimo et al., 1998; Venäläinen and Heikinheimo, 2003; Vajda et al., 2014). In calculating FFI, the volumetric moisture content of a $60-\mathrm{mm}$-thick soil surface layer is estimated by using potential evaporation and precipitation data. The calculated moisture content is then transformed into an index value.

In this chapter we focus on the two indices (FFI and Canadian Fire Weather Index [FWI]) applied in Finland and neighbouring countries. More detailed descriptions of FFI are presented by Heikinheimo et al. (1998) and Vajda et al. (2014).

The FFI simulates change in organic surface soil moisture content. FFI is a soil moisture index that was developed based on field measurements conducted at Lammi Biological Station in southern Finland during the summer of 1995. It simulates the moisture content of a $60-\mathrm{mm}-$ thick surface layer in an open clear-cut site where soil dries out more rapidly than inside a forest. The simulated moisture change in the surface layer is defined by precipitation, evaporation and the run-off of surplus water immediately after rainfall. Evaporation is estimated by calculating first the potential evaporation and then the actual evaporation using an empirical function of drying efficiency. Potential evaporation depends only on the atmospheric demand, whereas the actual evaporation also depends on the properties of the evaporating surface and is thus more complicated to estimate. For the current operational application, the potential evaporation is calculated using the Penman-Monteith equation (e.g. Monteith, 1981).

The calculation procedure yields the estimated moisture content of a surface layer, with a maximum value of volumetric moisture limited to $50 \%$ and minimum value to $10 \%$ (Heikinheimo et al., 1998). The monitoring of soil surface moisture begins immediately after the snowmelt when the soil is wet and near field capacity. At this point, the volumetric moisture 
of the surface layer is assumed to be 50\% (Heikinheimo et al., 1998). The change of water content (DW) in $\mathrm{m}^{3} \mathrm{~m}^{-3}$ is estimated as follows:

$$
D W=E p o t * \frac{0.757}{\{1+\exp [2.74-16.67 *(W v o l-0.1)]\}}+5.612 *\left[1-\exp \left(-\frac{P}{5.612}\right)\right]
$$

where $\mathrm{P}(\mathrm{mm})$ is the precipitation and Epot $(\mathrm{mm})$ potential evaporation and Wvol $\left(\mathrm{m}^{3} \mathrm{~m}^{-3}\right)$ is the volumetric moisture.

In operational use, FFI is calculated using gridded meteorological data. The input parameters needed in the calculation of potential evaporation include air temperature and humidity, surface radiation balance and wind speed. This data, with the exception of radiation balance, can be obtained from routine synoptic weather observations and are interpolated onto $10 \mathrm{~km} \times 10 \mathrm{~km}$ and $1 \mathrm{~km} \times 1 \mathrm{~km}$ grids using the kriging interpolation method, as explained in Aalto et al. (2016), for example. Radiation components are calculated using the cloud data from a numerical weather prediction model (NWP) with the necessary verification and modifications made by the duty forecasting meteorologist. Precipitation data is obtained from the Local Analysis and Prediction System (LAPS) model (Hiemstra et al., 2006) that combines various data sources including surface observations and radar measurements. Calculations are made using a three-hour time step. By using input from NWP, the development of fire risk is also forecasted for subsequent days.

The calculated volumetric moisture content is scaled into an index value ranging from 1 to 6 , with 1 indicating the lowest and 6 the highest possible fire risk (Table 5.1). A forest fire warning is issued when the index value reaches 4 , corresponding to volumetric soil moisture of less than $20 \%$. Pre-warnings are issued five days ahead at most. When the forest fire warning is in force, making open fires such as campfires is prohibited, and rescue service authorities raise their preparedness to suppress forest fires. Fire survey flight routes are operated once a day when the index value is between 4.1 and 5.3 and twice a day when FFI is at least 5.4.

Table 5.1. Description of the Finnish Forest Fire index (FFI) values.

\begin{tabular}{|l|c|l|}
\hline FFI & Volumetric soil moisture & Moisture status \\
\hline 6.0 & 0.10 & Very dry \\
\hline $5.9-5.0$ & $0.11-0.14$ & Dry \\
\hline $4.9-4.0$ & $0.15-0.19$ & Moderately dry \\
\hline $3.9-3.0$ & $0.20-0.25$ & Moderately wet \\
\hline $2.9-2.0$ & $0.26-0.32$ & Wet \\
\hline $1.9-1.0$ & $0.33-0.50$ & Very wet \\
\hline
\end{tabular}

The fire risk information is disseminated to the emergency authorities mainly through a special web server. The information includes maps as well as summarised values at a regional level. Tables containing mean FFI values for each administrative region and municipality are also 
available for the authorities. For the general public, the fire risk maps are visible on FMI's web page. The risk level is categorised using four scales from 'no particular awareness is needed', corresponding to an FFI value of less than 4, to 'very dangerous' (Fig. 5.2). The red alarm indicating the most dangerous fire conditions is issued only when terrain is very dry and high wind speed with gusts exceeding $15 \mathrm{~m} / \mathrm{s}$ are expected.

In springtime, there might be cured grass, leaves and other flammable debris that dries rapidly in open areas during the few weeks after snow melt, before the vegetation is fully developed. At this time of year the risk of grass fires may be high, although the forest terrain may still be wet. Thus, additional grass fire warnings are issued before the start of the forest fire season. These warnings are issued based on the grass fire index, which is calculated in a similar way to FFI but instead of a 60-mm-thick surface layer, moisture content is modelled for a thinner 30$\mathrm{mm}$ layer in order to accelerate the drying.

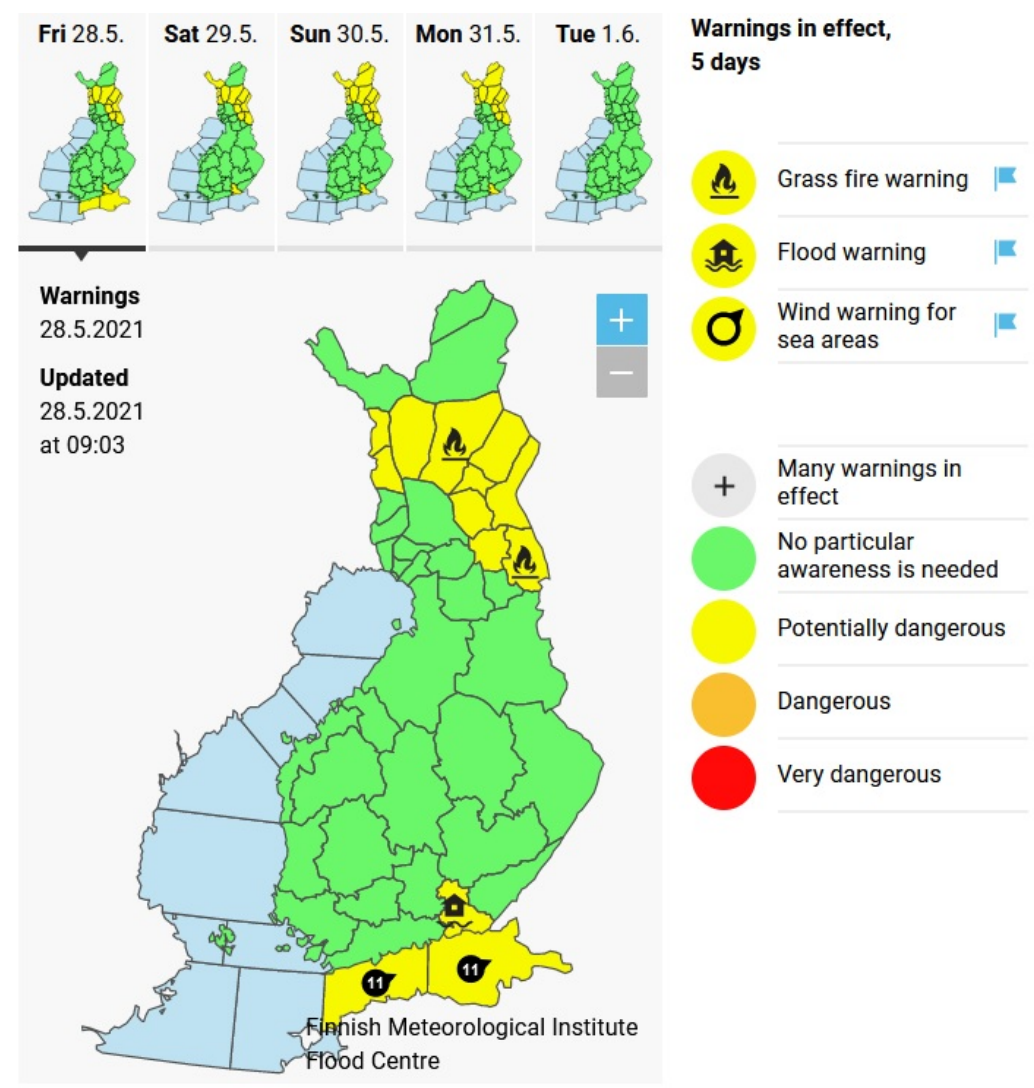

Figure 5.2. An example of the warnings' web page issued by FMI, including forest fire warnings in force on 28.5.2021.

The Canadian Fire Weather Index describes the behaviour and intensity of fires. The Canadian Fire Weather Index (FWI) system (Van Wagner, 1987) is probably the most widely used fire risk assessment system in boreal regions. Among the Nordic countries, it is operationally used in Sweden (e.g., Yang et al., 2015; Sjöström and Granström, 2020). As input variables, the FWI system requires midday values for air temperature, air humidity, wind speed and precipitation sum from the previous 24 hours. Calculations are made on a daily time step starting from snowmelt in spring and both station-specific or area-averaged weather data can be used. First, three different moisture codes are calculated. These describe the moisture 
conditions at different depths near the surface (Table 5.2). The moisture codes are further converted into three fire behaviour indices (Fig. 5.3). The Buildup index (BUI) indicates the total amount of fuel available for combustion by a moving flame front, and Initial spread index (ISI), which is affected by wind speed, indicates the expected rate of fire spread (De Groot, 1987). The final FWI rating is a dimensionless quantity combining ISI and BUI and indicates the likely intensity of a fire. The FWI rating is often converted into a daily severity rating (DSR), emphasising higher FWI values. DSR is expected to more accurately reflect the expected effort required for fire suppression. The conversion is performed through a power relation:

$\mathrm{DSR}=0.0272 \times \mathrm{FWI}^{1.77}$

Table 5.2. Fuel moisture codes in the FWI system (adapted from De Groot, 1987).

\begin{tabular}{|l|l|l|l|}
\hline Item & $\begin{array}{l}\text { Fine fuel moisture } \\
\text { code (FFMC) }\end{array}$ & Duff moisture code (DMC) & $\begin{array}{l}\text { Drought code } \\
\text { (DC) }\end{array}$ \\
\hline Fuel association & $\begin{array}{l}\text { Litter and other } \\
\text { cured fine fuels }\end{array}$ & $\begin{array}{l}\text { Loosely compacted organic } \\
\text { layers of moderate depth }\end{array}$ & Deep, compact organic layers \\
\hline $\begin{array}{l}\text { Fire potential } \\
\text { indicator }\end{array}$ & Ease of ignition & $\begin{array}{l}\text { Probability of lightning fires; } \\
\text { fuel consumption in moderate } \\
\text { duff }\end{array}$ & $\begin{array}{l}\text { Mop-up difficulty; fuel } \\
\text { consumption of deep organic } \\
\text { material }\end{array}$ \\
\hline Depth & $1-2 \mathrm{~cm}$ & $5-10 \mathrm{~cm}$ & $10-20 \mathrm{~cm}$ \\
\hline Time lag constant & 16 hours & 12 days & 52 days \\
\hline Value range & 0 (wet) to 99 (dry) & 0 (wet) to infinity (dry) & 0 (wet) to infinity (dry) \\
\hline $\begin{array}{l}\text { Maximum } \\
\text { probable value }\end{array}$ & 96 & 150 & 800 \\
\hline
\end{tabular}




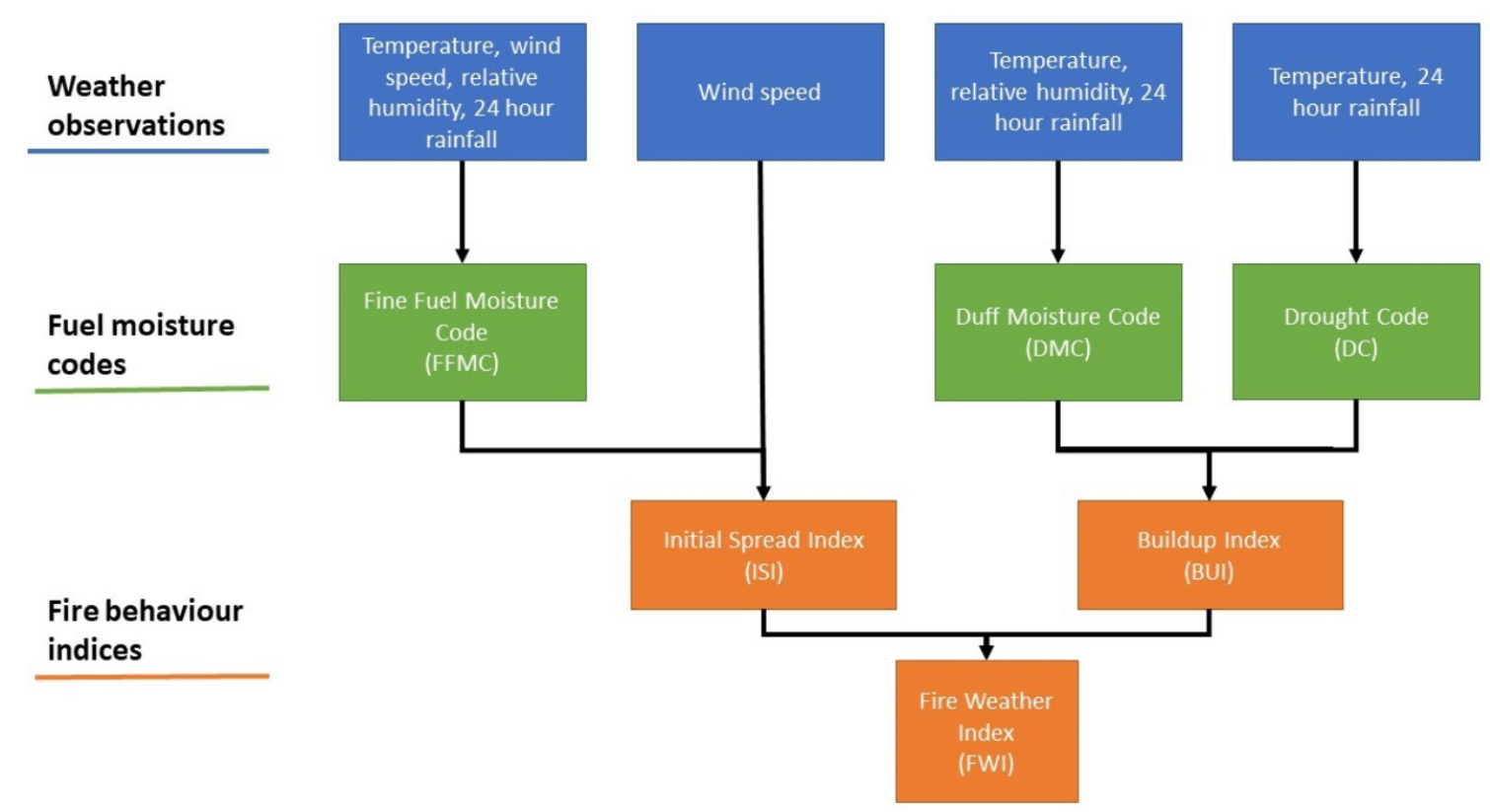

Figure 5.3. Schematic calculation structure of the Canadian Fire Weather Index (FWI). The fuel moisture codes are calculated using daily midday weather values. The fire behaviour indices are then calculated using these fuel moisture codes, giving estimates of fire intensity and initial spread rate, for example. Adapted from Van Wagner (1987).

The FWI system was initially developed empirically for Canadian boreal conditions and is generalised for pine forests (jack pine and lodgepole pine). However, the FWI indices have proved to be realistically linked to the moisture content of different forest fuels in many kinds of environments (Viegas et al., 2001) and the FWI system has become widely implemented in many countries around the world, including New Zealand (Pearce and Clifford, 2008), Spain (Padilla and Vega-Garcia, 2011) and Greece (Dimitrakapoulos et al., 2011), for example. Eventually, the FWI system has been suggested as the basis for a global early warning system for wildland fires (De Groot et al., 2006). The comparison of FWI to FFI has revealed that in Finnish conditions the two indices have similar performance (Vajda et al., 2014), although in experimental studies FWI has been shown to predict potential ignitions better than FFI (Tanskanen et al., 2005; Lindberg et al., 2021).

Other fire danger rating systems. Several countries have their own national fire danger rating systems. Here we shortly introduce the national systems used in the United States, Russia and Australia.

In the United States, the National Fire Danger Rating System (NFDRS) has been operational since 1972 (Schlobohm and Brain, 2002). The system uses air humidity, air temperature, solar radiation, precipitation and wind speed as input variables. Site-specific information is also included in the system. This contains data on location, average annual precipitation and the surrounding area and generally constant values, such as its slope class, fuel model, live fuel types and climate class. Different site descriptors are used in different ways. For example, the fuel model is used for calculating the danger rating, while the climate class is used to define the fuel drying rates for different fuel types. 
Outputs from the NFDRS consist of different fire-related values. These are the Spread Component (SC), Ignition Component (IC), Burning Index (BI) and the Energy Release Component (ERC). The SC depicts the predicted fire spread rate. The IC gives the probability initially for a firebrand to start a fire in the fine dead fuels and secondly the probability for a started fire to start spreading. The ignition probability is calculated from the fine fuel moisture and fuel temperature and the spread probability is based on the SC value. The BI is meant to estimate the contribution of fire behaviour to the effort of containing a fire. The value is calculated from the SC and ERC. Other outputs include the Adjective Fire Danger Ratings and the Staffing Level. The adjective fire danger rating is meant to be used to convey the fire danger situation to the media and the public. The staffing level is meant to be used as an aid in planning and determining the level of action needed overall. Higher values indicate larger fire potential and in turn require better preparedness, etc. It is based on historical data from the station, from which the fire danger continuum is formed.

In Russia, fire danger is evaluated using the Nesterov index (NI) developed in the 1940s (Nesterov, 1949). Several modifications and improvements have been made to the index since then, but the most used definition in the recent literature is the simple formulation provided by Chandler et al. (1983):

$$
N I_{t}=\sum_{i=0}^{w-1}\left(T_{15_{t-1}}-T_{d e w_{15 t-1}}\right) T_{15_{t-1}}
$$

where $\mathrm{T}_{15}$ is air temperature at $3 \mathrm{pm}$ in ${ }^{\circ} \mathrm{C}$, Tdew 15 is dew point temperature at $3 \mathrm{pm}$ in ${ }^{\circ} \mathrm{C}$, and $\mathrm{W}$ is the number of days since last daily rainfall greater than $3 \mathrm{~mm}$. The index is cumulative and resets to zero when the daily precipitation level exceeds $3 \mathrm{~mm}$. The index is particularly appropriate for capturing fine fuel moisture and thus predicting fire ignition, but less capable for predicting fire behaviour or spread (Stocks et al., 1996). In addition to Russia, the index has been used for prevention and research purposes elsewhere in Eastern and Central Europe.

McArthur's Forest Fire Danger Index (FFDI) and the Grassland Fire Danger Index (GFDI) are used in Australia for estimating forest fire danger rating levels in the two different fuel types (Dowdy et al., 2009). Warnings are issued by the government's Bureau of Meteorology in the afternoon for the following day. These warnings include information about the weather and possible recommendations for preparing for possible bushfires. The fire danger rating is based on the predicted difficulty of controlling or suppressing the fires. Danger ratings range from low to moderate up to catastrophic. The GFDI is calculated from the degree of grassland curing, air temperature, relative humidity and wind speed. In calculating the FFDI temperature, wind speed, relative humidity and drought factor are used to calculate the index value between 0 and 100. The drought factor is calculated using either the Keetch-Byram Drought Index (KBDI) or Mount's Soil Dryness Index (SDI).

\subsubsection{Surveillance from airplanes and satellites is needed to detect fires over sparsely populated areas}

Forest fire surveillance from airplanes. Regular forest fire surveillance flights are flown in summer in Finland when the forest fire index (FFI) exceeds predefined thresholds (see chapter 5.1.1). Currently, there are 22 surveillance flight routes, which are particularly designed to cover sparsely populated areas in Finland. When a forest fire warning is issued, the routes are flown once or twice per day, depending on the index. Table 5.3 shows statistics of the fire surveillance flights in Finland for 2008-2020. The number of reported flights includes all flights, including training flights. All fires observed on the surveillance flights are reported and 
listed in the table, including fires not classified as wildfires. In addition, fires earlier observed by different means are listed, and the number of fires first observed from the aircraft are given in the respective columns.

On average, a fire is observed on every fourth flight. In addition to regular surveillance, fire and rescue departments can request specific surveillance flights to confirm uncertain smoke sightings. Besides observing fires, the surveillance aircraft can be used to guide the fire departments in extinguishing large fires ('Guidance flights' in Table 5.3). Regular surveillance flights were started in the 1970s in Finland, initially to complement surveillance from fire observation towers, and as the only form of surveillance since the late 1980s. Currently, flight surveillance is complemented by near-real-time (NRT) satellite observations.

Table 5.3. Statistics of the fire surveillance flights in Finland in 2008-2020. Source: Regional State Administrative Agency for Northern Finland.

\begin{tabular}{|l|l|l|l|l|l|l|l|}
\hline Year & $\begin{array}{l}\text { Number } \\
\text { of flights }\end{array}$ & $\begin{array}{l}\text { Observed } \\
\text { wildfires }\end{array}$ & $\begin{array}{l}\text { First } \\
\text { obs. }\end{array}$ & $\begin{array}{l}\text { Observed } \\
\text { other fires }\end{array}$ & $\begin{array}{l}\text { First obs. } \\
\text { (other fires) }\end{array}$ & Smoke obs. & $\begin{array}{l}\text { Guidance } \\
\text { flights }\end{array}$ \\
\hline 2008 & 512 & 20 & 15 & 0 & 0 & 203 & 12 \\
\hline 2009 & 655 & 54 & 23 & 0 & 0 & 443 & 20 \\
\hline 2010 & 784 & 142 & 54 & 20 & 3 & 222 & 66 \\
\hline 2011 & 617 & 150 & 44 & 19 & 0 & 235 & 43 \\
\hline 2012 & 152 & 16 & 11 & 4 & 1 & 93 & 3 \\
\hline 2013 & 611 & 130 & 63 & 13 & 1 & 162 & 68 \\
\hline 2014 & 454 & 98 & 41 & 10 & 1 & 140 & 43 \\
\hline 2015 & 336 & 30 & 17 & 7 & 1 & 79 & 10 \\
\hline 2016 & 302 & 39 & 8 & 6 & 1 & 75 & 10 \\
\hline 2017 & 298 & 21 & 6 & 7 & 3 & 76 & 3 \\
\hline 2018 & 1407 & 343 & 125 & 33 & 8 & 206 & 116 \\
\hline 2019 & 762 & 151 & 66 & 26 & 9 & 135 & 46 \\
\hline 2020 & 704 & 143 & 45 & 49 & 24 & 99 & 36 \\
\hline
\end{tabular}

Forest fire surveillance from satellites. Satellite-based fire observations have recently been implemented for operational use at FMI to support fire and rescue services. They are especially useful in remote places in the country, where fires can otherwise burn unnoticed for longer periods. Fire detection from satellites is based on observing high emissions of thermal infrared radiation from spatially limited areas on the surface, or 'hot spots' (e.g. Schroeder et al., 2014; Giglio et al., 2016; Xu et al., 2020). Vegetation fires produce radiation at short wave infrared and thermal infrared wavelengths (e.g. Sullivan et al., 2003), which can be observed by many satellite instruments, typically using channels close to $3.7 \mu \mathrm{m}$ and $11 \mu \mathrm{m}$, if the fire is large and hot enough. The ability of satellites to detect fires depends on the satellite instrument's resolution, spectral response properties, viewing geometry and atmospheric conditions (e.g. cloudiness). The season and time of day as well as the background conditions of the fire site also play a role; fires are more easily detected when the background is cold.

The satellites used for fire detection are polar orbiting satellites which do not provide a continuous view of Fennoscandia, but snapshots taken by a few overpasses per day per instrument. Clouds or heavy smoke can prevent satellites from observing fires, and the 
requirement of cloud-free conditions may further reduce the frequency of observations. Timeliness of the data is also crucial in operational use. While some satellites (e.g. Moderate Resolution Imaging Spectroradiometer [MODIS], Visible Infrared Imaging Radiometer Suite [VIIRS]) use direct broadcast, which allows fast downloads at the Sodankylä satellite receiving station, some satellites (e.g. Sea and Land Surface Temperature Radiometer [SLSTR]) provide data only via specific processing sites, causing delays of up to a few hours.

The spatial accuracy of satellite fire alert is crucial for operational use. The accuracy depends on the satellite instrument and on the viewing geometry. On a single overpass the satellites typically cover a swathe $2000-3000 \mathrm{~km}$ wide, depending on the instrument. The accuracy is best at the satellite ground track (directly below the satellite) and is reduced towards the edges of the swathe. The sensitivity to fires is also reduced towards the swathe edges, where the satellite footprint (pixel size) is larger. Industrial facilities and urban infrastructure producing excess heat can cause false satellite fire alerts. In fact, for the newest and most sensitive instruments a large majority of the raw satellite fire detections can be false alerts. Known sites causing false alerts ('persistent hot spots') can be flagged to prevent false alerts in operational use. In addition to the bare brightness temperatures, some algorithms monitor spatial gradients to detect fires. A pixel with sharp contrast to surrounding background temperature may indicate fires. These fire tests can also cause false alerts in case of isolated brightly reflecting surfaces (small water bodies or scattered clouds). In the case of shortwave infrared channels, reflection of solar radiation from bright surfaces or clouds may contribute to false alerts. Setting the satellite fire detection thresholds is always a trade-off between not missing actual fires and avoiding false alerts. The algorithms are constantly developed further to remove false alerts. For satellite instruments that have been in use for several years, global fire detection thresholds have been tuned to optimal level, but for more recent instruments (with different resolutions and spectral response) more work is required.

Figure 5.4 illustrates the fraction of false alerts from one satellite instrument (VIIRS), based on classification of gridded pixels with simple statistical methods. Sites with persistent alerts due to industrial facilities are marked with red circles, and data points in these areas are labelled 'False' in the histogram. Large forest fires can also cause a large number of alerts, but on a temporally limited scale. Such data is referred to as 'dense' in the histogram, while 'sparse' data corresponds to more or less spatially isolated data points.

a)

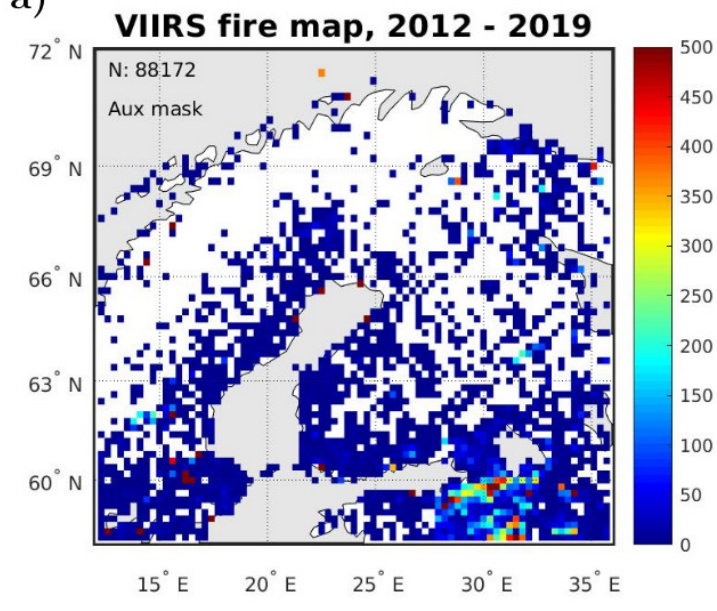

b)

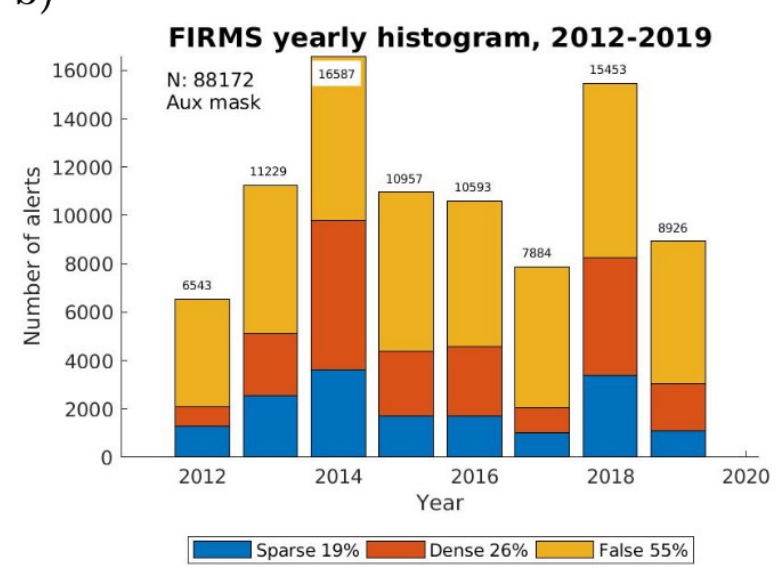

Figure 5.4. The number of fire alerts in Fennoscandia in 2012-2019 by VIIRS. 
Multiple satellite instruments can detect forest fires. Several polar orbiting satellite instruments are capable of detecting large fires: VIIRS (Schroeder et al., 2014) and Advanced Very-High-Resolution Radiometer (AVHRR; Plank et al., 2017) satellites operated by the National Oceanic and Atmospheric Administration (NOAA), MODIS (Giglio et al., 2016) operated by National Aeronautics and Space Administration (NASA), and the SLSTR (Xu et al., 2020) operated jointly by the European Space Agency (ESA) and by the European Organisation for the Exploitation of Meteorological Satellites (EUMETSAT). Some of the properties of these satellite instruments are summarised in Table 5.4.

Table 5.4. Specifications for satellite instruments used for active fire detection.

\begin{tabular}{|l|l|l|l|l|}
\hline Instrument & Platform & Swath width $(\mathbf{k m})$ & Spatial resolution $(\mathbf{m})$ & Launched \\
\hline VIIRS & Suomi NPP & 3060 & $375-700$ & 2011 \\
\hline VIIRS & JPSS-1/NOAA-20 & 3060 & $375-700$ & 2017 \\
\hline SLSTR & Sentinel-3A & 1400 & $500-1000$ & 2016 \\
\hline SLSTR & Sentinel-3B & 1400 & $500-1000$ & 2018 \\
\hline MODIS & Aqua & 2330 & $250-1000$ & 2002 \\
\hline MODIS & Terra & 2330 & $250-1000$ & 1999 \\
\hline AVHRR & $($ several) & 2500 & 1100 & $(1979)$ \\
\hline
\end{tabular}

Of the American satellite instruments, VIIRS is most sensitive to fires, and provides the highest number of alerts. Due to the high sensitivity, it also provides the largest number of false alerts due to urban/industrial heat sources. Thus, a careful filtering of the data is required in operational fire and rescue service use and climate and air quality applications.

The fire product for the European SLSTR instrument aboard Sentinel-3 satellites was released in April 2020 by EUMETSAT. SLSTR is a dual view instrument specifically designed for sea and land surface temperature retrieval and has two dedicated channels for fire detection. These channels do not suffer from saturation in case of high surface temperatures, which is a common issue for several satellite instruments. Unfortunately, Sentinel-3 data is only relayed via dedicated ground segment, with a time delay of at least three hours. SLSTR has suffered from quality issues that have delayed the publication of the fire product, and it was not possible to analyse the data for this report.

Other satellite products. In addition to fire detection, other satellite products related to forest fires are available. While these are not addressed in detail in this report, they are briefly described below for completeness.

Fire Radiative Power. Satellites can produce information on the fire radiative power (FRP, W), which describes the amount of radiation produced by the fire and hence contains information on the scale of the event. FRP is also a proxy for the rate at which material is consumed and emissions are produced by the fire. It is crucial, for example, in modelling the black carbon emissions from forest fires. FRP estimates are typically produced using the same infrared channels that are used for fire detection, but the required accuracy is higher and hence FRP is not available for all detected fires. 
Source data for dispersion models. Atmospheric transport models, such as the SILAM model at FMI (Soares et al., 2015), use satellite fire detection and FRP products for quantifying firerelated emissions needed in the dispersion models. The removal of false fire detections from the initial satellite data is crucial for reliable performance, and various thresholds are typically used to filter the data. So far, many models have used the MODIS fire product, and adaptation to use the more sensitive VIIRS data would require careful scrutinisation of the filtering methods.

Burned area. Information on the area consumed by the fire can also be used for estimating the amount of burned material and the resulting emissions. Data can be obtained from visible and infrared wavelengths, as well as from synthetic aperture radar satellites. Satellite instruments with high spatial resolution and long revisit times, such as Landsat- 8 and Sentinel-2, can be used for this purpose, since the product is not time critical.

Aerosols. Satellite aerosol products can also be used to monitor emissions from forest fires (see e.g. Wiggins et al., 2020). Satellite retrieval algorithms provide global estimates of the total aerosol optical depth (AOD), consisting of all aerosol types (natural background aerosols, industrial, sea spray, dust, smoke). While AOD is the main retrieval product, many algorithms also provide information on the aerosol type. Biomass burning aerosols produced by fires are typically strongly absorbing (low single scattering albedo, SSA) and can be identified from their spectral signal. Large forest fires can be seen in satellite AOD data on monthly scales. Large forest fires in Russia, Canada and South America, for example, are typically seen as elevated AOD and fine particle fractions, and as reduced SSA in Level-2 aerosol products (monthly 1-degree aggregates). Elevated AOD due to biomass burning aerosols are often seen in South-East Asia and West Africa. Satellite aerosol retrieval requires cloud free conditions, limiting the coverage. Thick smoke plumes can often be mistaken for clouds in the global retrieval algorithms. Tuning the algorithms for forest fire-specific retrievals could provide more information on the fire emissions.

Future aspects - towards utilising the full potential of satellites in fire surveillance. The fire detection capabilities of satellites are currently not fully utilised in fire surveillance. While satellite detection of active fires can be used to trigger alerts to local authorities, information of 'fire-free' areas could also be useful for example in planning fire surveillance flights. Satellite instruments cover high-latitude areas several times a day, and in cloud-free conditions they can provide information on areas where fires were not observed, and where the retrieval was not possible due to clouds or satellite coverage limits. It is possible to also develop map products where fire detection probability (depending on the observation conditions) is shown. If satellite data shows with reasonable confidence that there are no (large) fires, this information can be used for planning the observation flights.

Operational fire detection at the Finnish Meteorological Institute. There is an operational satellite fire detection and alert service in use at the weather service in Finnish Meteorological Institute (FMI). Data from several satellite instruments (VIIRS, MODIS, AVHRR) are received and processed in near real-time and email alerts are sent to local authorities and fire departments if a possible fire is detected in their respective areas. Currently the VIIRS satellite instrument (onboard the two NOAA satellites, Suomi-NPP and JPSS-1/NOAA-20) provides most of the fire detections. Fire detection algorithms developed by NOAA and NASA are used as such (no local modifications) (Schroeder et al., 2014; Giglio et al., 2016). VIIRS has channels at two nominal resolutions, $375 \mathrm{~m}$ and $700 \mathrm{~m}$, and separate products are produced at each resolution. 
Frequent false alert sites are being flagged, and fire detections from these locations are neglected. The list is updated as more cases are found.

VIIRS fire alerts need careful filtering. The main challenge in satellite fire surveillance is the removal of false alerts from the large number of possible fires detected by satellite algorithms. For a geographically limited area, a list of known locations causing false alerts can be manually compiled. For this project, a rudimentary study was made to find a more general way of filtering the data. In this study, we used fire alert data from the VIIRS satellite instrument obtained via the NASA/NOAA web-based Fire Information for Resource Management System (FIRMS).

Simple statistical thresholds can be used to filter out the most obvious sites causing persistent false alerts. First, the data was gridded to a $0.2^{\circ} \times 0.3^{\circ}$ latitude-longitude grid for the study area (latitude $58-72^{\circ} \mathrm{N}$, longitude $12-36^{\circ} \mathrm{E}$ ) and period (1.1.2012-30.9.2019), and the grid cells with more than 100 alerts were chosen as potential false alert grid cells. In total, 122 such cells were found, mainly in the Leningrad Oblast.

The spatiotemporal spread of alerts within a grid cell is used to determine if the grid cell needs to be flagged as a persistent fire grid cell, i.e. if it causes only false alerts. An industrial site will cause fire alerts that have a small spatial spread but large temporal range, while an actual large forest fire will have a larger spatial spread and a small temporal spread. In some cases, a grid cell includes both an industrial site and actual fires, which increases the spatial spread. On the other hand, actual fires can occur in the same grid cell several times over the years, increasing the temporal extent. Thus, the grid cells cannot be classified simply based on these two numbers as such. We use combinations of the spatial and temporal coverage and the corresponding standard deviations to flag the false alert grid cells. The fire radiative power (FRP) is also used, as the industrial sites tend to have a smaller FRP compared to large forest fires. Figure 5.5 shows some statistics of the potential persistent fire grid cells.

It is clear that the simple thresholds applied here do not remove all false alerts, and on the other hand they also remove part of the actual forest fires. Operational use for fire departments requires manually maintained databases of known false alert sites appearing frequently, but such an approach is not possible on a larger scale for climate and air quality purposes. However, even the simple approach described here illustrates the appropriate scales. From the 5600 grid cells in the study area, only $122(2 \%)$ show frequent alerts, but contain $81 \%$ of the alerts. Moreover, 31 grid cells $(0.6 \%)$ are considered to contain an industrial site causing frequent false alerts and contain $55 \%$ of all alerts.

a)

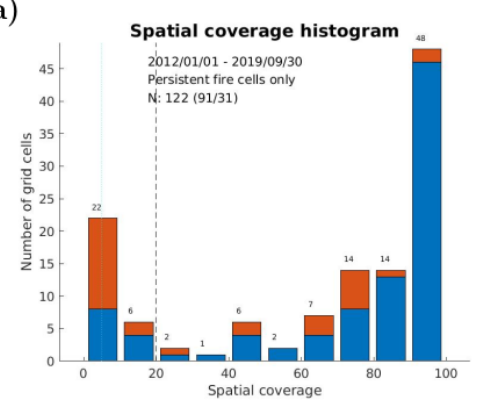

b)

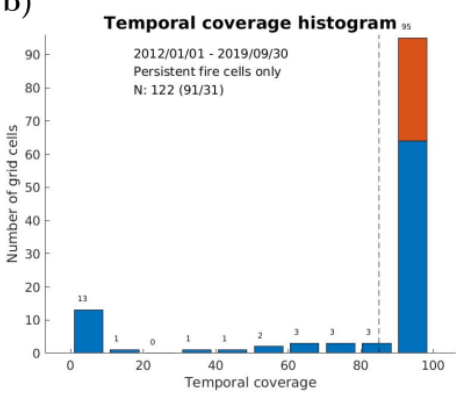

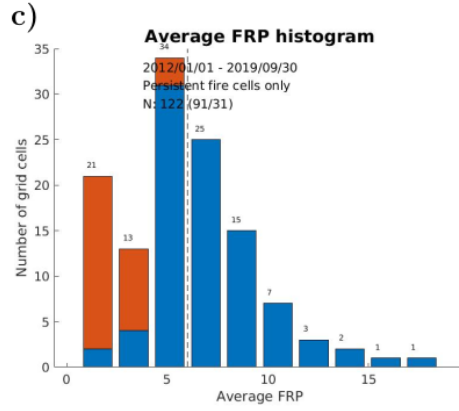

Figure 5.5. Statistics for potential false fire alert grid cells $(\mathrm{N}=122)$. Blue bars correspond to actual forest fire cells $(\mathrm{N}=91)$, orange bars correspond to false alert grid cells $(\mathrm{N}=31)$. Indicative thresholds are shown by the dashed vertical lines. 
Good satellite coverage over high-latitude areas. Since Fennoscandia is located at high latitudes, many of the satellite instruments cover parts of the area more than twice a day. In Figure 5.6 we demonstrate the combined VIIRS coverage over the area using both platforms carrying the instrument. Suomi-NPP crosses the equator at approximately 13:30 (ascending node) and at 01:30 (descending node), while JPSS-1 (NOAA-20) crosses the equator approximately 50 minutes prior to Suomi-NPP (at 12:40 and 00:40). These orbits mean that there are frequent overpasses from midnight to noon, but a large gap in the afternoon and evening. (All times are given in UTC.)

a)

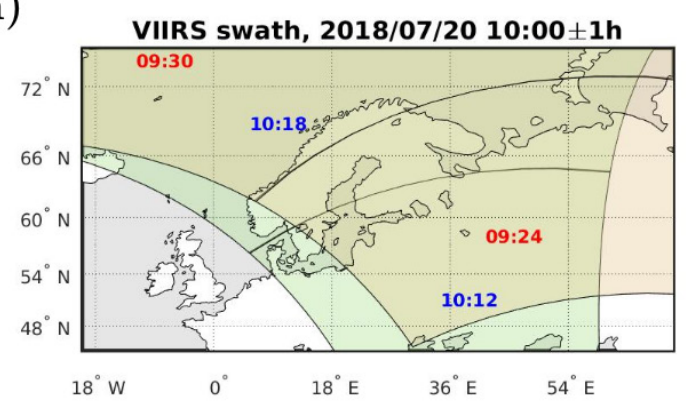

b)

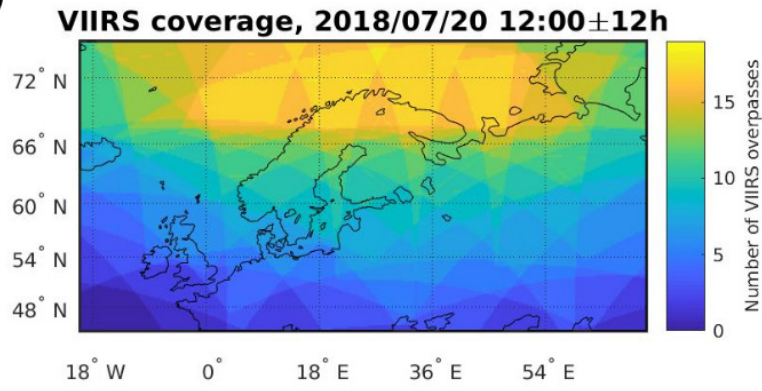

Figure 5.6. VIIRS satellite coverage over Fennoscandia. a) number of VIIRS overpasses in 24 hours. b) an example of consecutive VIIRS overpasses by the two platforms; red times for Suomi-NPP, blue for JSPP-1. Times in UTC.

Poor matching of VIIRS data with fire alerts over Finland. A comparison between the FIRMS/VIIRS satellite fire alerts and the Finnish PRONTO fire database (Emergency Services Academy Finland) was made for the period 2012-2019. Both sets of data were gridded to the same $0.2^{\circ} \times 0.3^{\circ}$ latitude-longitude grid over Finland, and temporal matches within 12 hours were searched for over each grid cell. The VIIRS data was first filtered by removing data from grid cells corresponding to industrial sites causing frequent false alerts. All PRONTO alerts were used, although it would have been possible to remove small and urban fires from the comparison. From the 2114 VIIRS alerts, a matching PRONTO alert was found for 449 alerts $(21 \%)$. Figure 5.7 shows density maps of original alerts, matching cases, and the VIIRS alerts for which matches were not found.
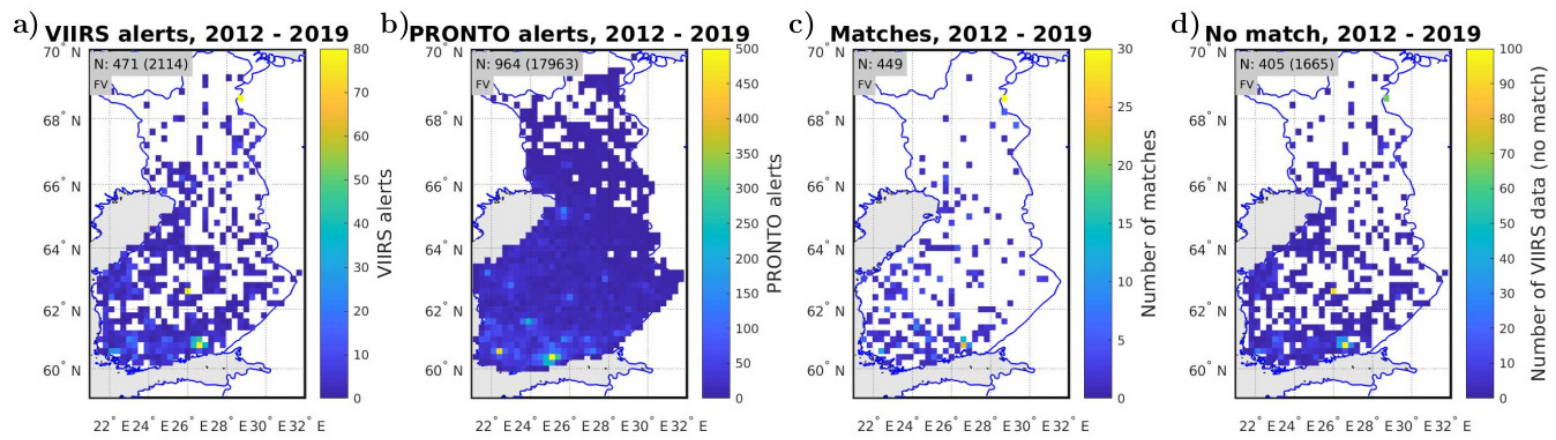

Figure 5.7. Comparison of filtered VIIRS and PRONTO fire alert data in Finland. a) Density plot of VIIRS fire alerts. b) Density plot of PRONTO fire alerts. c) Density plot of spatiotemporal matches between the data. d) Density plot of VIIRS alerts for which a PRONTO match was not found. The text inserts show the number of grid cells (data points within these grid cells) for each case. 
The low number of matches may be partially explained by three observations. Firstly, limiting the VIIRS data to areas over Finland may not be exact: large fires just outside Finland may be included in the VIIRS data but not in the PRONTO database. Secondly, some industrial sites were clearly not removed by the filters applied to the VIIRS data. For example, a pulp factory in Äänekoski started operations in the middle of the study period and was not removed by the applied thresholds due to the relatively low temporal extent of the false alerts. Thirdly, frequent fire alerts from agricultural areas in southern Finland occur periodically in springtime in the VIIRS data, with no corresponding records in the PRONTO data. It is possible that these are related to prescribed burn-clearing of crop fields, which are not necessarily included in the PRONTO database. In addition, the duration of fires is not reported in the PRONTO data. For large forest fires lasting several days there may only be one record in the PRONTO data, while the satellite observations include data over several overpasses. Although such fires are rare, the large number of associated satellite data points may strongly affect the statistics. Further manual filtering of the VIIRS data from these effects could lead to a significantly higher match rate.

The selected grid cell size affects the results of the comparison. Four different grid cell sizes were used, as shown in Table 5.5. The columns show (from left) the grid cell size in degrees (longitude $\times$ latitude), the grid size as the number of grid cells, the number of grid cells which have at least one VIIRS alert, the number of grid cells which have at least one PRONTO alert, the number of grid cells which have at least one spatiotemporal match between the two data sets, the number of original VIIRS data points in the comparison (this varies with grid size since the filtering of VIIRS data depends on the grid cell size), and the number of VIIRS data points which have a spatiotemporal match with PRONTO.

Table 5.5. Comparison results for VIIRS vs. PRONTO fire alerts with different grid cell sizes.

\begin{tabular}{|l|l|l|l|l|l|l|}
\hline $\begin{array}{l}\text { Grid cell size } \\
\text { (deg.) }\end{array}$ & $\begin{array}{l}\text { Grid size } \\
\text { (cells) }\end{array}$ & $\begin{array}{l}\text { VIIRS } \\
\text { cells }\end{array}$ & $\begin{array}{l}\text { PRONTO } \\
\text { cells }\end{array}$ & $\begin{array}{l}\text { Matching } \\
\text { cells }\end{array}$ & $\begin{array}{l}\text { VIIRS } \\
\text { data }\end{array}$ & $\begin{array}{l}\text { Matching } \\
\text { data }\end{array}$ \\
\hline $0.06 \times 0.04$ & $300 \times 200$ & 1083 & 7750 & 169 & 2139 & $304(14.2 \%)$ \\
\hline $0.10 \times 0.06$ & $200 \times 120$ & 932 & 5133 & 177 & 2282 & $324(14.2 \%)$ \\
\hline $0.30 \times 0.20$ & $60 \times 40$ & 471 & 964 & 175 & 2114 & $449(21.2 \%)$ \\
\hline $0.60 \times 0.40$ & $30 \times 20$ & 205 & 295 & 111 & 1921 & $569(29.6 \%)$ \\
\hline
\end{tabular}

\subsubsection{Fire propagation modelling simulates the spread of fire}

Fire propagation modelling systems have a common goal: to simulate the spread of fire in heterogeneous topography, fuel and weather conditions. The actual method of producing these simulations vary from the simplest cellular propagation models to coupled fire-atmosphere models that require supercomputers. The end user of the modelling system must be considered when selecting or developing a fire spread model. For example, a firefighter needs fast and easy access to processed information, while a fire dynamics research team needs as spatially accurate information as possible about the dynamics of the spreading fire, regardless of the processing time or data requirements.

In addition to operational use, fire spread models can also be used to recognise risk areas, plan their fuel type management and recognise the most likely fire propagation paths through an 
area. Examples of programs designed for such risk management and planning uses are the Canadian Burn-P3 (Parisien et al., 2005) and the American FlamMap (Stratton, 2008) programs. These models can be used to run multiple fire spread simulations with minor variations in fuel types, weather, etc. in order to map the most likely paths of fire spread and identify risk areas.

In this chapter, we introduce some basic concepts of modelling of fire spread. One model, Prometheus, will be described in more detail since it will be applied in operational weather service at the FMI.

Classification of the fire spread modelling methods. Fire spread modelling techniques can be classified in different ways. For example, one of the methods described by Pastor et al. (2003) is to classify them by the nature of the equations used by the models. Using this classification, the fire spread modelling methods can be separated into three groups: theoretical models, empirical models and semi-empirical models. These groups have been compared in Table 5.6.

Empirical models (e.g. Anderson et al., 2015; Rossa and Fernandes, 2018) are the simplest form of fire spread models and they are based on the data collected from both real forest fires and experimental burns. Since these models are built on statistical correlations, they are computationally efficient. The downside, however, is that the models only perform well in similar conditions that are represented by the empirical data (Pastor et al., 2003).

Semi-empirical models, like empirical models, use data collected from actual forest fires and experimental burns, but also include some form of theoretical models such as the Canadian FWI and FBP models used in Prometheus (Tymstra et al., 2010). These models combine the low to medium computational requirements with a higher level of accuracy and transferability compared to the empirical models. Therefore, they are more suitable for operational use. However, they require the usage of multiple different assumptions regarding fuel types, weather effects, etc., which may cause unwanted behaviour in the fire spread model results. This unwanted behaviour can consist of errors such as fire spread rates that are too fast or slow, and errors in fire intensity calculations. This is because the modelling of fire spread may take too long in a situation where information is quickly needed for decision making.

The last group, theoretical models, are the most computationally heavy forms of fire spread modelling. They use physical factors such as combustion, heat transfer and fluid mechanics to calculate the spread of fire (e.g. Coen, 2013). Due to the high computational requirements, they are not well suited in operative use and their usage is mostly limited to research. This is because the modelling of fire spread may take longer than the actual spread of a fire. 
Table 5.6. Comparison of the empirical, semi-empirical and theoretical models. As one moves from empirical models towards theoretical ones, the required amount of empirical assumptions decreases while the computational requirements increase. Larger computational requirements cause longer run times/increase in required processing power, limiting the simplicity and operational usability of the model.

\begin{tabular}{|l|l|l|l|}
\hline & Empirical models & Semi-empirical models & Theoretical models \\
\hline $\begin{array}{l}\text { Computational } \\
\text { requirements }\end{array}$ & Very low & Low - Medium & Very high \\
\hline Use & $\begin{array}{l}\text { Fire propagation } \\
\text { research under set } \\
\text { conditions }\end{array}$ & Operational/planning & $\begin{array}{l}\text { Research/study of } \\
\text { past fire events }\end{array}$ \\
\hline Pros & Very fast simulations & $\begin{array}{l}\text { Combination of modelling speed and } \\
\text { quality of results }\end{array}$ & $\begin{array}{l}\text { Ability to model } \\
\text { complex events (fire } \\
\text { whirls, etc.) }\end{array}$ \\
\hline Cons & $\begin{array}{l}\text { Simplicity of the } \\
\text { models, only work in } \\
\text { certain conditions }\end{array}$ & $\begin{array}{l}\text { Multiple assumptions required, can } \\
\text { become computationally intensive in } \\
\text { larger fires }\end{array}$ & $\begin{array}{l}\text { Run-time limits to } \\
\text { research use }\end{array}$ \\
\hline $\begin{array}{l}\text { Example } \\
\text { programs }\end{array}$ & $\begin{array}{l}\text { Models developed } \\
\text { mostly for the research } \\
\text { of certain fire affecting } \\
\text { factor }\end{array}$ & FARSITE/PROMETHEUS & CAWFE \\
\hline
\end{tabular}

Modelling fire front propagation. Once the fire spread-related values have been calculated with the chosen method, the actual propagation of the fire front needs to be modelled. This is commonly done in two different ways: grid-based propagation (or Cellular automata) and vector-based propagation. The level set method is a third option, but it is not as common as the other two methods.

Grid-based modelling is the simplest form of fire propagation modelling. It consists of fire spreading from one grid cell to another, based on a predefined set of rules, such as the probability of a cell igniting under certain weather and/or fuel conditions. This propagation method can be implemented in a simple and computationally efficient way but can also suffer from limitations. These limitations include the limited amount of directions the fire can spread to in a grid, the aggregation of fuel data within cells (Tymstra et al., 2010), and the grid-like shape of the fire front (Feunekes, as cited in Tymstra et al., 2010). Some of the limitations can be mitigated by using different grid cell shapes (such as hexagon or Voronoi polygons [see Johnston et al., 2006; Encinas et al., 2007]) and by allowing the fire to spread further than to the next neighbouring grid cell.

Vector propagation models are based on Huygens' discovery of the propagation of light waves. Based on this discovery, the shape of the fire can be represented as a polygon, which is formed by multiple straight-line segments forming the closed path. The meeting points of the polygonforming straight-line segments are considered as the polygon's vertices and from these vertices the fire propagates as independent elliptical wavelets. Fire behaviour-affecting conditions, such as the fuel type and weather values, at the vertex are used to determine the direction and rate of spread of the fire spreading wavelet (Tymstra et al., 2010). This has been demonstrated in 
Figure 5.8. Gwynfor D. Richards developed a partial differential equation to implement the Huygens propagation discovery into fire spread modelling (Richards, as cited in Tymstra et al., 2010; Finney, 2004). For example, the well-known models FARSITE (Finney, 2004) and Prometheus (Tymstra et al., 2010) use these partial differential equations for fire spread modelling.

a

b

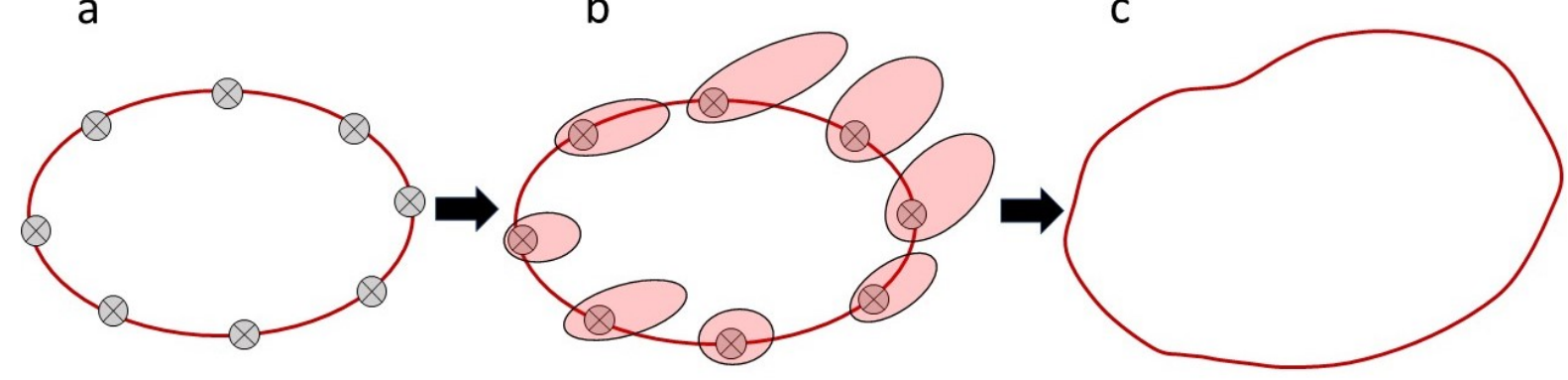

Figure 5.8. The different steps during vector-based propagation (Tymstra et al., 2010). In step $a$, the vertices along the fire perimeter are selected. In step b, the fire spread is calculated from each selected vertex using information about the fuel type and weather values in the current cell and speed. The fire spread depicting ellipse is formed using these values. Finally, in step c, the new fire perimeter is formed, and the loop starts from step a. Adapted from Tymstra et al. (2010).

Another method usable in fire front propagation is the level set method. A common problem with the vector propagation models is the difficulty of modelling fire front convergence and front merging, while the level set method can model such situations in a computationally efficient way (Mallet et al., 2008). For example, Ghisu et al. (2014) compared the quality and speed of a level set method to the well-known vector-based fire spread model FARSITE. The results of the level set method showed similar quality to that of FARSITE while being much faster to compute.

Prometheus - The Canadian forest fire spread modelling program. The Canadian Prometheus program is a semi-empirical deterministic fire spread modelling program (Tymstra et al., 2010). It is based on the Canadian Forest Fire Danger Rating System (CFFDRS) and its two subsystems, the Fire Weather index (FWI) and the Fire Behaviour Prediction (FBP). Using these subsystems, the Prometheus program can give estimates of wildfire spread in heterogeneous landscapes. An in-depth description of the FWI subsystem has been given in Section 5.1.1.

The development of the CFFDRS began back in the 1970s and the development of the Prometheus program started in 1999 with its first version being released in 2002 (Tymstra et al., 2010). It is being actively updated, with the latest version (6.2.4) being released on 13 January 2019. The program has been using a five-part Windows COM environment, PrometheusCOM, consisting of FireEngine, FuelCom, FWICom, GridCom and WeatherCom (COM Programmer Documentation, 2014). The other members of the Prometheus software family, such as Pandora and Burn-P3, use this COM environment to access the fire spread modelling capabilities of Prometheus. The program is currently undergoing development, in which Prometheus turns into Prometheus System as a Service (PSAAS). New additions to the program are the capability of cloud computing, running the program on multiple different platforms such as Windows and Linux, and lastly the capability of using the program in a 
supercomputer environment. This new version of Prometheus is currently being beta-tested in the FMI and will be set up for operational use.

The FBP subsystem gives information about fire spread-related values, such as potential head fire spread rate and fire intensity. The original system is based on the measurements from 495 fires, which include prescribed fires, wildfires and experimental fires. These measurements were used to estimate the fire spread values (fire intensity, potential head fire spread rate, etc.) in 16 different fuel classes. Collected information from the experimental fires consist of information about the fuels, weather, topography and fire behaviour. Actual wildfire data consists of data related to extreme fire behaviour (such as spotting distances), which cannot be gained in experimental fires (Hirsch, 1996).

The FBP systems fire spread rate calculations use information from five groups: weather, fuel type, topography, foliar moisture content and the type and duration of the prediction (Fig. 5.9). Weather consists of FFMC, ISI and BUI values from the FWI system in addition to the hourly wind speed and direction values. Fuel type contains the fire spread rate parameters associated with each fuel type. Topography is the percentage slope and upslope direction values derived from a digital elevation model (DEM). Foliar moisture content is calculated from the elevation, coordinates and date from the area. Lastly, the type and duration of the prediction consists of two types of prediction, point source and line ignition. These are used to determine if the fire has reached its equilibrium rate of spread (Hirsch, 1996). Using the values from these categories, the FBP system calculates the primary and secondary outputs, which are listed in Figure 5.9.

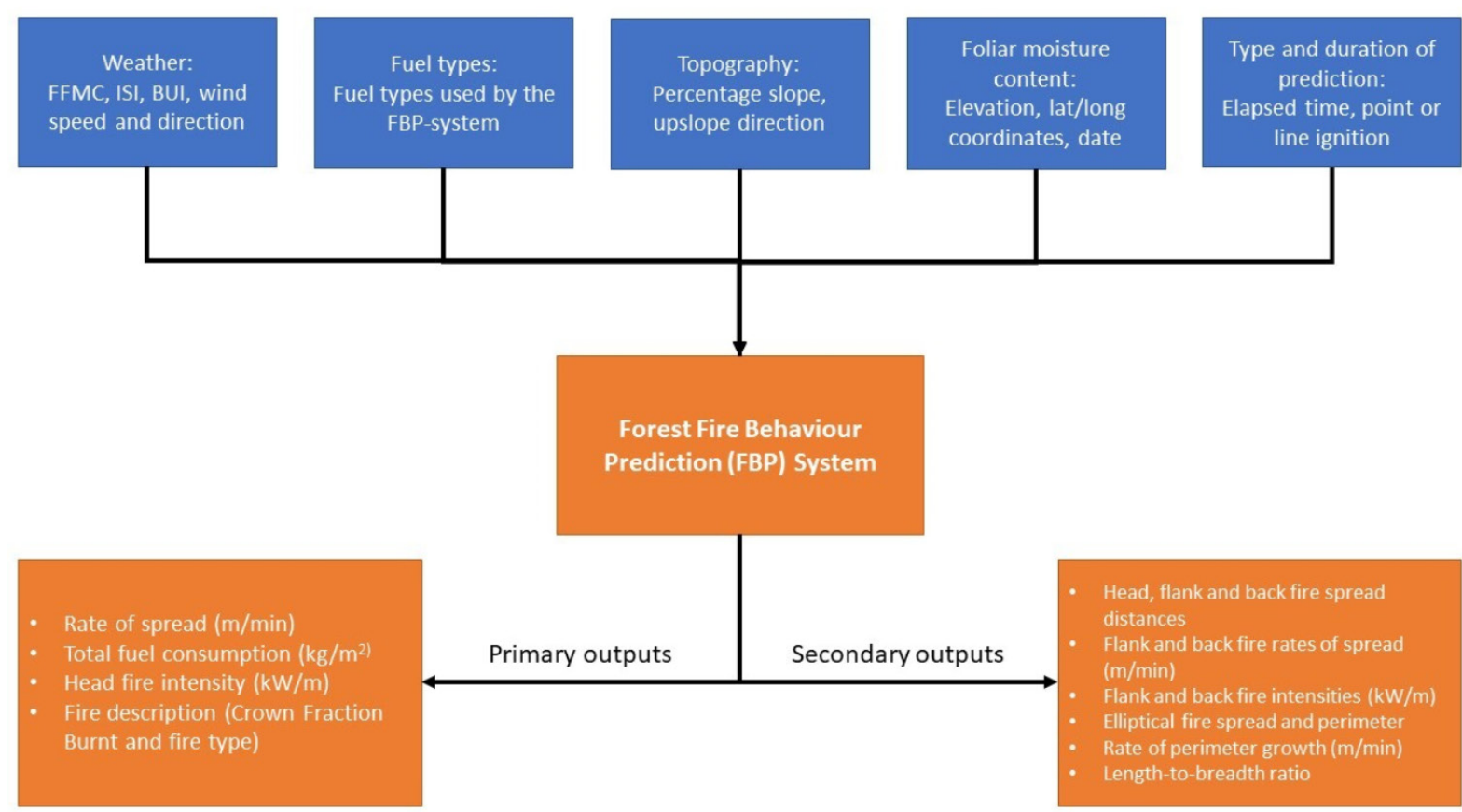

Figure 5.9. The different parts of the Forest Fire Behaviour Prediction FBP system and the produced outputs. Adapted from Hirsch (1996).

Input data requirements. In order to use the Prometheus fire spread model, information about the fuel, weather and ignition point time and locations in the area are the minimum data requirements. However, in order to increase the quality of the model results, it is recommended 
to use other optional data, such as vectorised fire break elements (roads, water, etc.) and a DEM of the area. Information about the fuel in the area can be provided in two ways. First, the different fuel types are given to the program in table format (for example, csv). These contain parameters required for the FBP system calculations and other possible information about the fuel, such as tree height or grass curing percentage. Second, information about the fuel topography of the area of interest needs to be given as a grid file (ascii or GeoTIFF format). The program uses the csv fuel type table in the FBP calculations according to the fuel type in the currently burning grid cell.

Weather information is given to the program in table format (for example, csv), which contains hourly values for air temperature, relative humidity, precipitation, and wind speed and direction. Apart from the wind direction, these values are used to calculate the FWI system fuel moisture code values, as presented in section 5.1.1. These values are then used to determine fire spread rate related FBP system indexes (Fig. 5.9). Wind speed and direction are the most direct fire spread affecting values, determining the shape and direction of the spreading fire front.

Modelling fire propagation with Prometheus. Prometheus is a wave-based propagation model. Combining the values calculated in the FWI and FBP subsystems and the partial differential equations based on Huygens' principle of wave propagation, fire growth can be simulated in the program. Modelling the spread of fire starts by forming a polygon at the ignition point/line/area and, depending on the shape of the ignition, different vertex formations are used. Fire vertex points are chosen along the edges of the polygon and from these points the rate of spread is calculated using the FBP and FWI values, fuel type, slope and aspect values of the grid cell (Fig. 5.9). The locating and propagation of the vertices is based on partial differential equations developed by Richards (1990). When every vertex point has been 'extinguished' by hitting a non-fuel area, or when the scenario time ends, the simulation stops (Tymstra et al., 2010).

The immediate output of the program is the propagation of the simulated fire in the area. The temporal resolution of when the new fire front is drawn can be defined by the user. The files produced by the program come in four forms: grid files, vector files, text files and csv tables. The grid files consist of data related to the FWI and FBP system values, in addition to other fire behaviour-related information. The vector file represents the fire perimeter at the chosen timestep; this includes every timestep previous to the chosen one. An example of this can be seen in Figure 5.10, where a real wildfire in Lieksa, Finland, was modelled twice to see how the fire would have spread without interference. The resulting text files contain information related to each simulation run, such as data used and possible errors. Lastly, the csv tables provide the same information as the grid files at the used temporal resolution of the simulation. 


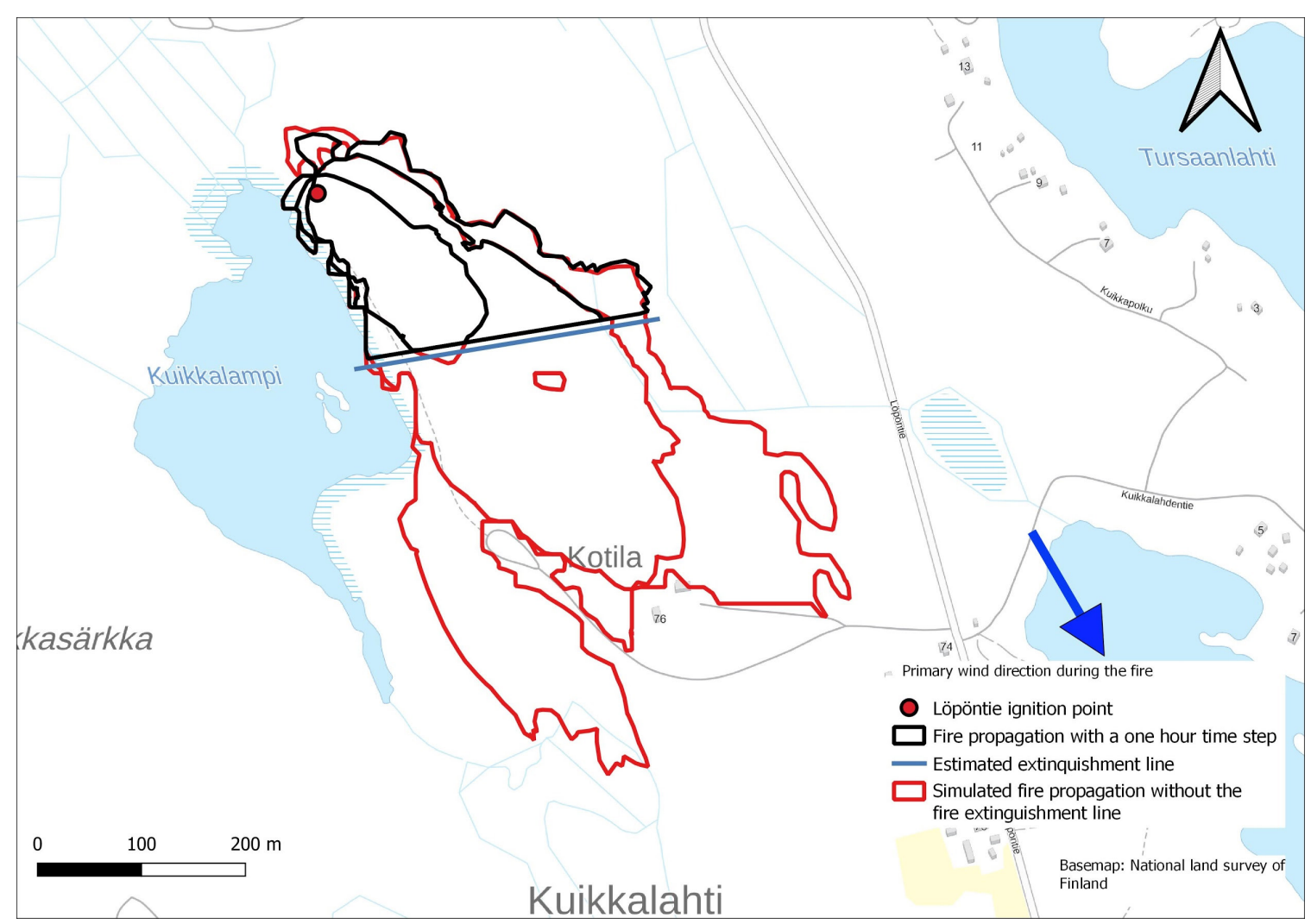

Figure 5.10. An example of the outputs of the Prometheus model. The simulation representing a real fire in Lieksa, Finland, was run twice, once with the estimated fire extinguishment line and once without it. According to the simulation, the fire would have spread to the nearby houses of Kotila without the extinguishment line. Adapted from Kolstela (2020).

Current limitations of fire spread modelling. Although fire spread modelling has come a long way since the days of manual calculations using a pen and paper, there is still much work to be done. There is currently a large variety of different fire spread modelling programs, each with their own methods and assumptions. However, none of the options is without its limitations. Programs meant to be used in an operational sense require more assumptions about the fire propagation dynamics. This allows for faster run times, but it also means that factors such as fire-atmosphere dynamics cannot be considered in the propagation modelling. The high-end theoretical fire propagation models are able to model these dynamics, but the increased computational requirements limit the use to mostly laboratory and research purposes. Even these programs make multiple assumptions about the fuels, moisture values, etc.

Data-related assumptions are another problem. The resolution used for fuel grids cannot present the true heterogeneity of the vegetation in a forest, so some level of spatial aggregation will always be required. Even if the fuel grid resolution could be increased to capture all of the different fuel features in an area, the computational costs would increase, especially when modelling extremely large fire events. Apart from theoretical propagation models, this is also true for one of the most important fire behaviours affecting variable - wind. Wind speed and direction values are spread across the grid and are updated at intervals of an hour or more. The accuracy of the wind grids can be increased by using software such as Windninja (Wagenbrenner et al., 2019), which can calculate higher-resolution grids and thus capture the effects of local topography on wind speed and direction. However, this adds to the computational cost of running the fire spread model, so on lower end computing environments this could lower the operational usability of the selected fire spread model. 
Commonly, the fuel types represent the natural vegetation found in the area responsible for the program's development (Canadian vegetation in Prometheus, US vegetation in FARSITE/CAWFE etc.). It would be important to investigate how well these in-program fuel types represent the ones to be used, as this could have a large effect on the reliability of the model results. For example, the fuel types used by the Canadian Prometheus fire spread model have been parameterised from actual and experimental fires in Canada. Adapting these fuel types would require a large amount of work in order to readjust the parameters according to the local vegetation.

\subsection{Demand for rescue services amid changing climate and forest conditions}

In this subchapter, we address forest fires specifically from the perspective of rescue services. First, we take a look at the rescue services system, which in Finland is based on both full-time and part-time rescue personnel. We then analyse the number of forest fires and their characteristics in the field of rescue services' operations. We will continue by looking at forest fires in the light of both the rescue documentation and the survey material. After mapping out future challenges and the ways in which they can be solved, we will look at another case example that illustrates the number of different actors that have to work alongside one another for a rescue operation of a major forest fire to succeed.

A survey was carried out for this research package (Kukkonen, 2021) on both rescue and forestry operators. In this context, we emphasise the results and development proposals derived from the responses given by rescue personnel.

\subsubsection{About the structure of rescue services in Finland in brief}

Twenty-two rescue departments form the basis of the Finnish rescue services (Fig. 5.11). Prior to the current region division, each municipality had their own fire brigade, but in 2004 the current regional system was introduced. At times there have been plans to (even drastically) reduce the number of rescue services during the planning stages of the regional reform, which has been underway for several years and relate especially to the field of social and health services. 


\section{Fire Stations in Finland 2021}

\section{Stations}

- Professional fire brigade 24/7

a Professional fire brigade 24/7 with volunteer support

a 1-3 professional fire men 24/7 with volunteer support

a Volunteer fire brigade with professional support on the daytime

- Volunteer fire brigade

\section{Rescue Departments}

1. Rescue Services of Helsinki

2. Rescue Services of Western Uusimaa

3. Rescue Services of Central Uusimaa

4. Rescue Services of Eastern Uusimaa

5. Rescue Services of Southwest Finland

6. Rescue Services of Kanta-Häme

7. Rescue Services of Päijät-Häme

8. Rescue Services of Kymenlaakso

9. Rescue Services of South Karelia

10. Rescue Services of South Savo

11. Rescue Services of Central Finland

12. Rescue Services of Pirkanmaa

13. Rescue Services of Satakunta

14. Rescue Services of South Ostrobothnia

15. Rescue Services of Ostrobothnia

16. Rescue Services of Central Ostrobothnia and Pietarsaari region

17. Rescue Services of North Savo

18. Rescue Services of North Karelia

19. Rescue Services of Jokilaaksot

20. Rescue Services of Kainuu

21. Rescue Services of Oulu-Koillismaa

22. Rescue Services of Lapland

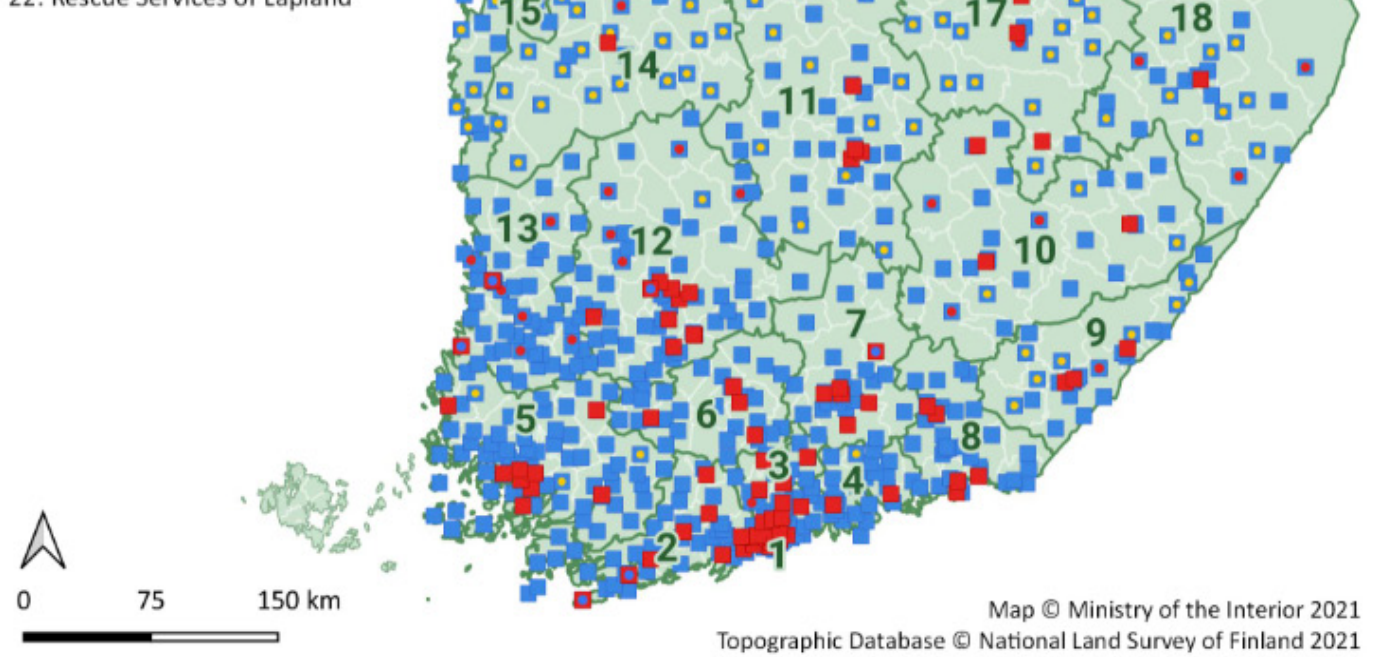

Figure 5.11. Fire stations and regional rescue departments of Finland.

The autonomous region of Åland has its own provincial rescue service. We will discuss the rescue services in mainland Finland. 
In large and long-lasting fires in particular, a rescue department's own resources may prove to be limited when sufficient operational capacity must also be maintained for other incidents during the fire. A rescue department should, if necessary, provide assistance to another rescue department (Rescue Act 379/2011, Section 45). The activities of the rescue departments are financed by the municipalities in its territory. For example, if a major forest fire generates a large number of additional costs, municipalities may apply for a discretionary increase in central government transfers to local authorities for exceptional and temporary financial problems (Act on Central Government Transfers to Local Government for Basic Public Services (1704/2009), section 30).

The personnel of rescue facilities consist of both full-time professional staff - the officials of the rescue departments - and contracted fire brigade members who participate in rescue operations alongside their main occupation. The contracted fire brigades have entered into an agreement with the rescue department to perform the tasks covered by the rescue services. Contracted fire brigades play a particularly crucial role in sparsely populated areas as they handle rescue operations in an area that covers about $90 \%$ of Finland's surface area. The remaining $10 \%$ of the areas consist of larger built-up areas, where contracted fire brigades play an important role in supporting professional fire brigades and as a reserve in case of overlapping or large-scale situations. (Pieni opas..., 5-10.) The role of contractual fire brigades is also illustrated by the fact that in 2018 there were about 15,000 contracted personnel belonging to emergency departments, while there were about 6,300 full-time personnel working in rescue services, including administrative and support services (Ketola and Kokki, 2019).

According to the Rescue Act, 'the Ministry of the Interior directs and steers rescue services and maintains oversight of their coverage and quality' and 'is in charge of the preparedness and organisation of rescue services at national level' (Rescue Act section 23, subsection 1). Finland is divided into six areas, where regional state administrative agencies maintain oversight of rescue services and their coverage and quality within their area of operation (Rescue Act, section 23, subsection 2). In addition, regional state administrative agencies shall organise an effective forest fire watching in sparsely populated areas if there is a manifest risk of forest fires (Rescue Act, subsection 31). Operations are handed over to regional rescue departments by emergency centres, of which there are six in Finland.

All operations carried out by rescue services are reported in the rescue services' resource and incident statistics PRONTO. Even from an international viewpoint, PRONTO forms an extensive and versatile source of information regarding rescue services' operations. For example, in the case of a forest fire, both alarm report and an accident report are made. The alarm report contains the information received and forwarded by the emergency centre, while the accident report contains a description of the development of events and rescue activities, and estimates of property damage.

\subsubsection{Proportion and role of forest fires in rescue services operations}

Compared to the total number of rescue operations carried out by rescue services, forest fires form a reasonably small but relatively rather laborious share of operations (Table 5.7). Extinguishing forest fires is labour intensive and often involves a large amount of personnel and equipment. This takes its toll on standby readiness, and the concentration of wildfires and forest fires for certain periods of time puts pressure on staff members' ability to cope at work. In forest fires, post-operation maintenance of the equipment is also laborious. 
Table 5.7. Emergency operations carried out by rescue services and proportions of fires, wildfires and forest fires (source: PRONTO)

\begin{tabular}{|c|c|c|c|c|c|}
\hline Year & 2016 & 2017 & 2018 & 2019 & 2020 \\
\hline Emergency operations in total & 103756 & 104411 & 113480 & 107971 & 101973 \\
\hline - of which fires & 12063 & 11854 & 14268 & 12602 & 12041 \\
\hline - of which wildfires & 2008 & 2181 & 4252 & 2920 & 2641 \\
\hline - of which forest fires & 975 & 920 & 2475 & 1499 & 1336 \\
\hline $\begin{array}{l}\text { Number of forest fires in actual } \\
\text { forests, commercial forests }\end{array}$ & $\begin{array}{l}758 \\
(77.8 \%)\end{array}$ & $\begin{array}{l}669 \\
(72.7 \%)\end{array}$ & $\begin{array}{l}1934 \\
(78.1 \%)\end{array}$ & $\begin{array}{l}1180 \\
(78.7 \%)\end{array}$ & $\begin{array}{l}1012 \\
(75.7 \%)\end{array}$ \\
\hline $\begin{array}{l}\text { Number of forest fires in logging } \\
\text { areas or clearings }\end{array}$ & $\begin{array}{l}203 \\
(20.8 \%)\end{array}$ & $\begin{array}{l}225 \\
(24.5 \%)\end{array}$ & $\begin{array}{l}481 \\
(19.4 \%)\end{array}$ & $\begin{array}{l}277 \\
(18.5 \%)\end{array}$ & $\begin{array}{l}294 \\
(22.0 \%)\end{array}$ \\
\hline Number of forest fires in bog areas & $\begin{array}{l}14 \\
(1.4 \%)\end{array}$ & $\begin{array}{l}26 \\
(2.8 \%)\end{array}$ & $\begin{array}{l}60 \\
(2.4 \%)\end{array}$ & $\begin{array}{l}42 \\
(2.8 \%)\end{array}$ & $\begin{array}{l}30 \\
(2.2 \%)\end{array}$ \\
\hline
\end{tabular}

Chapter 3 presents a time series of forest fires. Table 5.8 lists all the emergency tasks received by the rescue service in the past five years based on PRONTO data. In addition to fires, these include traffic incidents and automatic fire alarm inspection and verification tasks. The average number of fires (building fire, vehicle fire, wildfire, other fires) is about 12500 per year. Of these, the number of wildfires has varied over the last five years from about 2000 to more than 4200 cases. It is evident that in the case of Finland, the weather conditions from spring to early autumn greatly affect the number of wildfires.

The last four rows of the table relate specifically to forest fires, which are one subtype of wildfire. Only some wildfires are located in forests; with the exception of the dry summer of 2018 that saw a high number of forest fires, in other years under review forest fires made up well below half the total number of wildfires. On the other hand, PRONTO reporting divides forest fires into three different types based on their location: fires located in naturally occurring or commercial forests, fires located in logging or other clearings or forest glades, or fires located in other bog areas. The three last rows show the breakdown of the three different types of forest fire. According to PRONTO records, about four-fifths of the fires are located in naturally occurring forests.

Forest fires that receive public attention usually cover large areas. This easily leads to a misconception of the overall picture. The vast majority of forest fires are quite small. 
Table 5.8. The division of burnt forest areas by order of magnitude in 2016-2020 (source: PRONTO)

\begin{tabular}{|l|l|l|l|l|l|}
\hline Year & $<\mathbf{0 . 5}$ ha & $\mathbf{0 . 5}-\mathbf{1}$ ha & $\mathbf{1 - 5}$ ha & $>\mathbf{5}$ ha & Grand total \\
\hline 2016 & 916 & 39 & 49 & 14 & 1018 \\
\hline 2017 & 848 & 49 & 55 & 19 & 971 \\
\hline 2018 & 2218 & 123 & 187 & 38 & 2566 \\
\hline 2019 & 1391 & 81 & 68 & 21 & 1561 \\
\hline 2020 & 1231 & 70 & 67 & 25 & 1393 \\
\hline Total & 6604 & 362 & 426 & 117 & 7509 \\
\hline
\end{tabular}

When looking at forest fires in general during the past five years, the rescue authority has assessed the area of burnt forest to be less than half a hectare in $88.0 \%$ of cases. Fires ranging from half a hectare to five hectares make up $10.5 \%$ of the fires during the period under review, and fires covering over 5 hectares make up only $1.6 \%$ of the total. The number of fires is greater than the number of forest fires mentioned in the previous table, as the forest area has burnt in fires other than those forest fires in the previous table (e.g. building fires which spread slightly to the forest floor).

\subsubsection{Forest fires from the perspective of rescue services - risk assessments at the national and regional level}

One form of European Union cooperation is the Union Civil Protection Mechanism. It is a key instrument for international assistance, covering both natural and human disasters, such as major incidents and chemical and environmental incidents (EU:n siviilipalvelumekanismin...).

The Union Civil Protection Mechanism obliges Member States to regularly evaluate risks that can cause the need to request help from other countries. The latest national risk assessment was carried out in 2018. From a national perspective, forest fires are often regional, but in the event of several large-scale fires overlapping, the disruption may become national. The risk of forest fires and their spreading will increase in the future due to the combined effect of strong winds, high temperatures and low humidity (Kansallinen riskiarvio 2018).

In addition to and in support of the preparation of the national risk assessment, regional risk assessments considering specific local factors were carried out by each of the rescue departments. The following is a summary of the main observations from these documents mapping regional risk assessments. For some rescue departments, forest fires do not play a very large role in rescue services. Here we have especially considered risk assessments by the Central Finland, North Savo, Lapland and Kainuu rescue departments, as they each cover extensive forest areas, which has forced these rescue departments to consider and prepare for the risk of forest fires in particular.

From the point of view of individual rescue departments, the biggest problems caused by forest fires relate to two situations. The first of these situations is that if conditions are favourable, several simultaneous forest fires may lead to one or more of them spreading widely. At the 
same time the fires require a lot of personnel, which reduces the number of personnel available for other operations. Another major risk situation is if the fire spreads close to settlements, or smoke nuisance spreads widely into the populated area. In such a situation, the fire may have serious health and social effects. At worst, smoke can also cut off traffic connections, which can make food and other transportation more difficult. During a fire, power lines, telecommunication lines and electrical devices may also be damaged. The increased installation of underground electric lines in recent years reduces the realisation of these risks. Peat production is carried out in many rescue department areas; a fire from a peat production area may spread to the forest - or a forest fire may spread to the peat area.

Many risk estimates emphasise the risks caused by hiking and other movement in nature when it comes to igniting a forest fire. The deterioration of fire skills in everyday life can lead to campfires being lit in the wrong places and at the wrong time, and the fires are then extinguished poorly or not at all. Smoking in terrain that is extremely dry is also a risk factor. From the perspective of safety communication, language barriers make the problem worse: for example, tourists from abroad may not necessarily have information on the Finnish forest fire warning system. Berry pickers that work in fields and in forests and that mostly come from other countries may have attitudes towards making food on an open fire that may not be suitable for dry summer conditions. Forest management activities, such as screefing in dry conditions, also increase the risk of forest fires. Regarding natural phenomena, lightning strikes that hit transformers, for example, can also cause wildfires and forest fires.

Rescue departments that are located on Finland's borders also consider the possibility of forest fires spreading from another country. Most commonly, forest fires spreading from Russia are addressed. The Lapland Rescue Department had experience of such a situation from 2018 when a forest fire spread to Finland's territory in Inari. The more sparsely populated the area is, the fewer people there are to observe kindled fires. There is also a higher likelihood that there are fewer forest roads and other roads in the region. For example, in large national park areas, the road network is sparse, and at the same time the forest floor coefficient increases the risk of crown fires.

The rescue departments in charge of their area's rescue operations must draft a 'service standard decision' after consulting its area's municipalities. Risk assessments work well as the basis for this work, as the decision shall 'specify the threats in the region and assess the risks arising from them, and also determine the objectives of the operations, the available resources and services and the standard of service. The decision on the standard of service shall also contain a plan on the further development of the standard of service (Rescue Act section 29).

In the service's standard decisions, the issue of forest fires appears only sporadically so far, but when it does, it is also stated that as the climate changes, the number and size of forest and wildfires can cause a shift in focus, for example in preparedness and equipment procurement. Here, the division of labour between local rescue departments can also be utilised: for example, in operations where the rescue departments of Lapland, Kainuu, Jokilaakso and OuluKoillismaa cooperate, the latter specialises in high-power pumping, which is necessary, for example, in large forest fires (Oulu-Koillismaan pelastuslaitoksen palvelutasopäätös 2021-2024, 40). A document from one rescue department mentioned a plan made together with forest authorities for both preparedness for storm damage and forest fire prevention (Pirkanmaan pelastustoimen palvelutasopäätöksen tarkistaminen 2020-2021). 
Especially in areas with extensive forests and abundant peat production, such as OuluKoillismaa and Lapland, forest fires are identified as major incidents that require preparation and drills to carry out successfully (Oulu-Koillismaa pelastuslaitoksen palvelutasopäätös 2021-2024; Lapin pelastuslaitoksen palvelutasopäätös 2020-2023). The forest fire warning period - especially if it lasts a long time - can lead to changes and reinforcements in the oncall and standby systems (e.g. Pohjois-Savon pelastustoimen palvelutasopäätös 2021-2023). The starting point in the management of the rescue department operations is that they are performed without delay, but for example in a difficult forest fire situation, the tasks are prioritised (Rescue Act Section 28).

\subsubsection{Rescue and forest sector perceptions of forest fires - results of the survey}

As part of this project, Lapland University of Applied Sciences conducted a survey addressed to representatives of both the forest sector and the rescue service. A total of 494 respondents took part in the June 2020 survey, of which about two-thirds $(335,68 \%)$ represented the rescue services and about one-third $(159,32 \%)$ the forest sector. The aim of the survey was to obtain information on respondents' perceptions of quantitative changes in forest fires, good practices in fire prevention and extinguishing, and future needs. The entire dataset is reported separately in Kukkonen (2021), and here we present some of the key findings with the emphasis on the responses of the rescue service representatives.

The aim of the survey was to provide answers to the following questions:

- What are the perceptions of the forest sector and the rescue service sector of the number and causes of forest fires?

- What should forest fire prevention focus on in the future?

- What new methodological solutions or services will be needed in the future?

In rescue services, the survey was addressed both to full-time and contracted personnel through industry organisations. The survey was shared among rescue services by its interest groups, such as the Finnish National Rescue Association, the Finnish Association of Fire Officers, and the Federation of Finnish Contract Fire Brigades. In the forest sector, the survey was shared through forest management associations and Metsähallitus (a state-owned enterprise that produces environmental services), among others. The majority of respondents in the forest sector $(82 \%)$ consisted of white-collar workers or supervisors (e.g. forest planners and forest experts), $14 \%$ represented the managerial level, and only $4 \%$ of respondents were operational level workers. Respondents in the rescue sector were more evenly distributed: $39 \%$ of the respondents were operational level workers, 35\% were white-collar workers and supervisors, and $26 \%$ were senior civil servants or managers. Respondents had a wealth of work experience in the field (median career length 20 years), as well as a wealth of experience with forest fires: $80 \%$ of the rescue services respondents had performed rescue-related practical work in a forest fire situation more than 10 times (Kukkonen, 2021).

Six out of ten respondents representing the rescue services estimate that the number of forest fire incidents has increased in recent decades in the Fennoscandian region. In Finland, however, the situation was estimated to be better than in the rest of Fennoscandia. Respondents in both the rescue services and the forest sector estimate the fires to be currently small in size. This was estimated to be the sum of many things: aerial surveillance and satellite surveillance, effective cooperation between authorities, the effectiveness of rescue services (both full-time and contracted fire brigades), the amount of commercial forestry, the moderate size of forest patterns, and a dense forest road network were all seen as factors that improve the fire situation. 
In addition, the density of mobile phones makes alerting easier: in remote regions in the past, a lot of time may have been spent finding a phone connection whilst the fire had time to grow.

According to the respondents from the rescue services, this good starting situation will be challenged in the future by changing weather conditions: more than three quarters $(78 \%)$ of rescue services respondents estimate that climate change will increase the risk of forest fires in Finland in the future (Fig. 5.12).

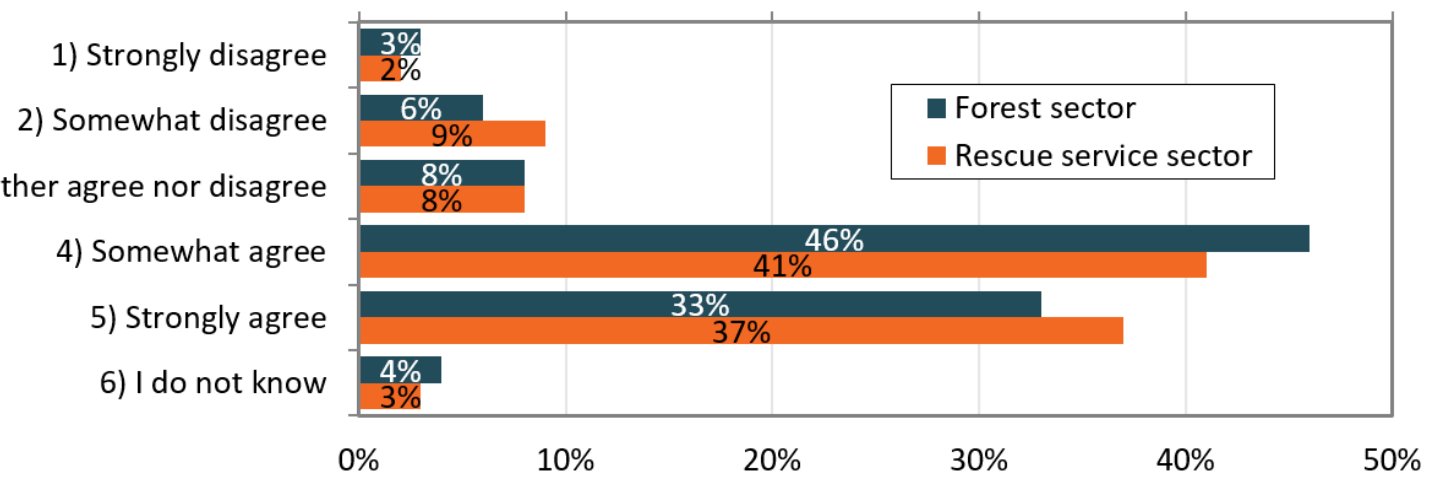

Figure 5.12. Distribution of questionnaire responses among respondents representing the forest sector and the rescue service sector to the statement: Climate change increases the risk of forest fires in Finland ( $\mathrm{n}=494$; Kukkonen, 2021).

About three quarters $(73 \%)$ of the respondents in the rescue sector also thought that the preparedness to fight forest fires should be increased in Finland, especially due to climate change (Fig. 5.13).

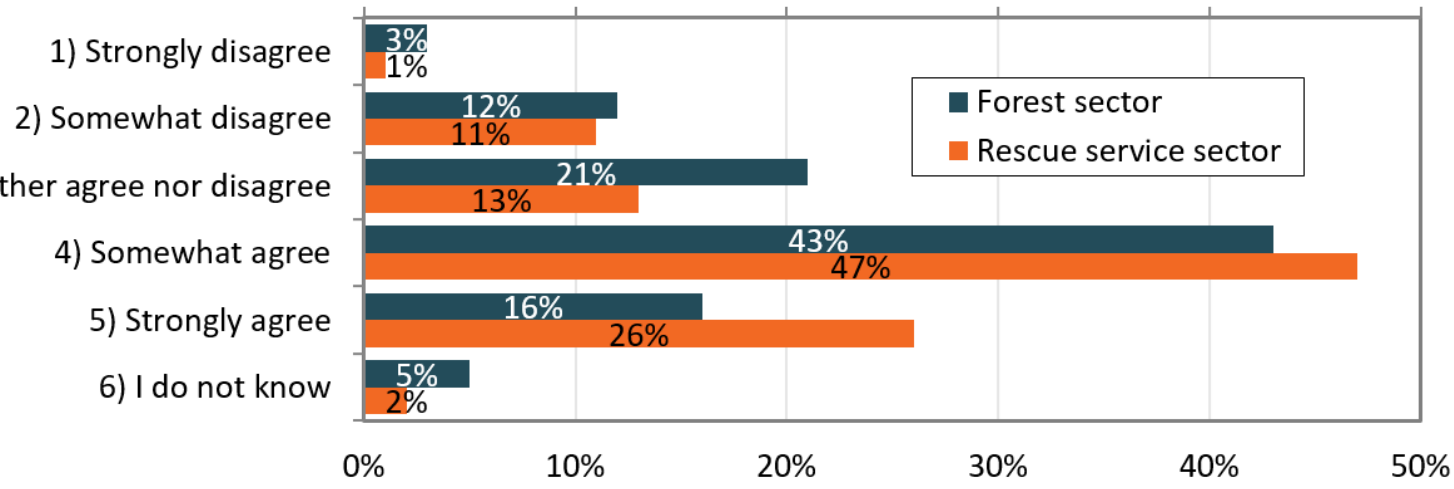

Figure 5.13. Distribution of questionnaire responses among respondents representing the forest sector and the rescue industry to the statement: The preparedness to fight forest fires should be increased in Finland, especially due to climate change (n=494; Kukkonen, 2021).

In recent decades, Finnish forestry has grown even-aged forests and has mainly focused on managed monocyclic stands. The amendment to the Forest Act, which entered into force in 2014, also enables continuous cover forestry, and especially in the case of state forests, nature organisations have demanded that clear cutting be abandoned. However, based on the survey, perceptions of whether a wider transition to continuous cover forestry would increase the risk of forest fires are very evenly distributed for and against (Fig. 5.14). 


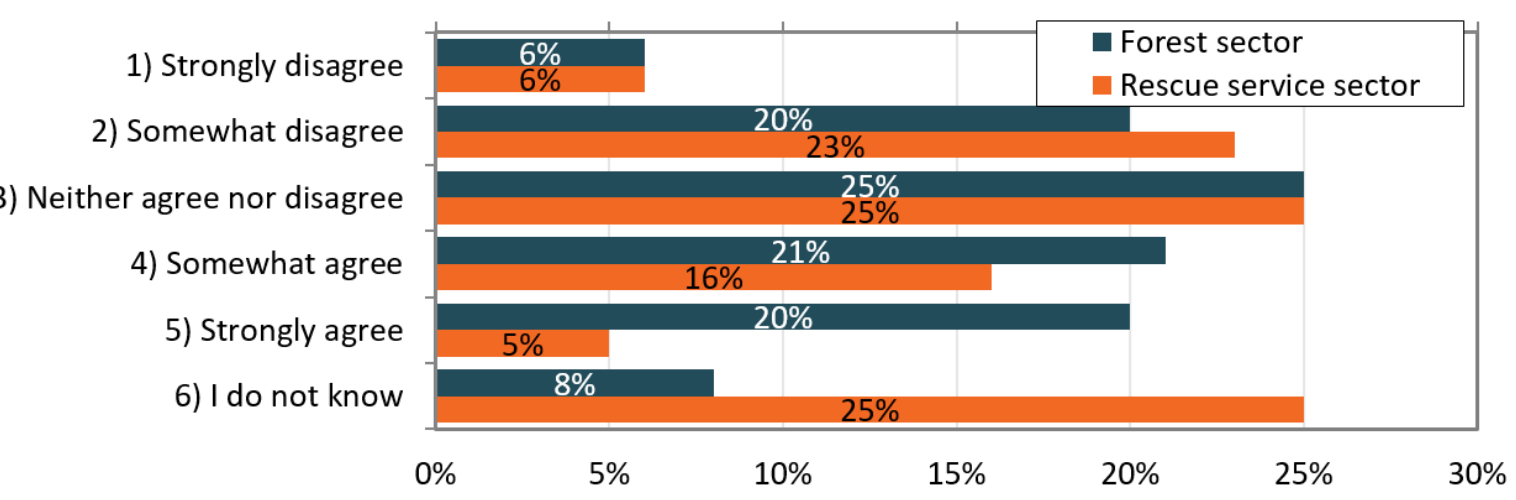

Figure 5.14. Distribution of questionnaire responses among respondents representing the forest sector and the rescue service sector to the statement: The risk of forest fires in Finland increases if we switch from clear cutting to continuous cover forestry ( $n=494$; Kukkonen, 2021).

Estimates in the verbal responses, however, suggest that continuous cover forestry increases the risk of fire in a forest with several canopy layers, as the fire can spread more easily from lower canopy layers to higher ones. On the other hand, forests with continuous cultivation have a lower fire load, as they tend to grow less forest capital than even-aged forests. In addition, in clear cutting areas, strong sunlight can cause large dry areas where the fire can originate from a spark generated by mechanical harvesting of logging residues or tillage.

\subsubsection{Future changes, challenges - and solutions}

Both groups of respondents see human activity as the main cause of forest fires (Kukkonen, 2021). PRONTO data supports this notion: for example, in 2017, rescue authorities estimated that $76 \%$ of wildfires were caused by human activities (Ketola and Kokki, 2018). These include fires ignited by poorly extinguished campfire bases or careless smoking.

Influencing people's actions is paramount. There are both softer and harder ways to do this. The primary means is related to public safety communication and education. Two-thirds of respondents in the rescue sector $(67 \%)$ emphasised increasing awareness. Instruction should begin in schools, and there should be more education about handling fires and extinguishing campfires for people who spend time outdoors. A good suggestion was to concretise what a forest fire warning means in practice: 'No smoking or campfires in the terrain, no throwing cigarette butts out of the car window, and avoiding the use of hot work machines'. Also, worth considering was one respondent thinking that education should include information about the cost of firefighting work and the exertion required from volunteers, which could improve attitudes towards risk-taking. Citizens' experiences with fires and camping has decreased, and so they may not be able to correctly identify risks, meaning that the issue should be urgently addressed. For example, nature tourism operators could play an important role in public safety communication, where the challenge is compounded by the need for multilingualism (Kukkonen, 2021).

Public safety communications have traditionally been part of rescue services' range of incident prevention tools. Instead, very little attention has been given to the possibility of using the threat of sanctions as a way to reduce undesirable activities, as is the case with traffic. A number of respondents that were rescue services representatives raised the issue of how important it is to intervene in intentional and negligent behaviour. Strong attention was paid to this in 2019-2020, when a project by Emergency Services Academy Finland focused on the reporting 
obligations of rescue authorities. Rescue authorities have a duty to report fires to the police that they consider to be intentional and negligent, fires in which the cause of ignition remains unclear, and cases where there is a reasonable suspicion of a rescue offence.

The written reporting procedure introduced in the project has already significantly increased the number of rescue offences in particular (Mäkelä, 2021). A significant number of reports registered by the police as rescue offences are related to violations of the prohibition on making open fires (Rescue Act Section 6). In the data from 2018-2019, 62\% of the reports registered as rescue offences by the police and $80 \%$ of the fines imposed for rescue offences were related to violations of the prohibition on making open fires (Salonen, 2020; see also Lehtimäki and Mäkelä, 2018). For forest fires, the criminal offences in question and their application are detailed in Kallio (2018).

In the survey data, individual respondents suggested toughening sanctions for intentional or negligent activities that lead to a forest fire, or even collecting extinguishing costs from the person who caused the fire (Kukkonen, 2021). However, this is not possible based on the current case law on the basis of a decision of the Supreme Court (KKO 1992:131). Instead, a person may be liable for forest damage caused by the fire. There are however no precedents for compensation and liability issues in the case of forest fires caused by logging and tillage work, for example (Nieminen, 2020), and no aggregated information is available on other compensation practices related to forest fires.

As one of the possibilities for preventing forest fires, the respondents suggest that the fire-watch obligations for dry and fire-hazardous forest management work should be specified and made more binding. Here it would be possible to harness the power of technology; in recent years, drones in particular have greatly facilitated and accelerated reconnaissance and fire-watching in areas. Similarly, it would be worthwhile investing in the first aid firefighting skills of those who use forest machines, as well as in equipment: if the machines in peat production areas are equipped with a fire water tank, the same could be considered for forest machines (Kukkonen, 2021). It is compulsory for forest machinery to be equipped with first aid firefighting equipment, but this is only intended to extinguish machinery fires, not forest fires. It was also suggested that surveillance technology could be added to forest machinery, such as thermal cameras monitoring the terrain to the rear (Kukkonen, 2021). Climate change has increased the risk of sparks from forest machinery not only in the form of warmer and drier summers, but also by causing warmer and wetter winters. This has weakened winter wood gathering conditions, which, combined with the monthly balancing of raw material flows, has increased wood gathering during the summer months (Nieminen, 2020).

Fire ignition is not always preventable. The next important step is to notice the fire as soon as possible. Regional risk assessments have taken into account the importance of aerial observation and still evolving satellite monitoring to detect fires in sufficient time. Likewise, mobile phones have accelerated the process of detecting fires and their location. The dense network of forest roads ensures that rescue vehicles can get close to fire sites, and in Finland natural water sources are usually quite readily available. The development of applications for locating operations will speed up the process of getting help (risk assessments from the Central Finland, North Savo, Lapland and Kainuu rescue departments). The widely used 112 application provides caller location information to the emergency centre, which greatly facilitates the location of the target. 
As the rescue services have identified an increased risk of forest fires due to climate change, attention has also been paid to the capacity to extinguish forest fires. The most interesting development work in Finland relates to an extinguishing tank connected to forest machinery (Fig. 5.15). The South Savo Rescue Department in particular has invested in the development of this tank. In forest fires, difficult terrain and the often-long duration of operations burden and slow down services. Work is much easier when firefighting water and equipment can be taken into the forest without clearing long distances (Hyttinen, 2020). A lighter alternative for carrying out surveys, for example, is to use a quad bike when moving in a forest fire area, and rescue operations will be facilitated in the future if drones with a high carrying capacity become available (Kukkonen, 2021).

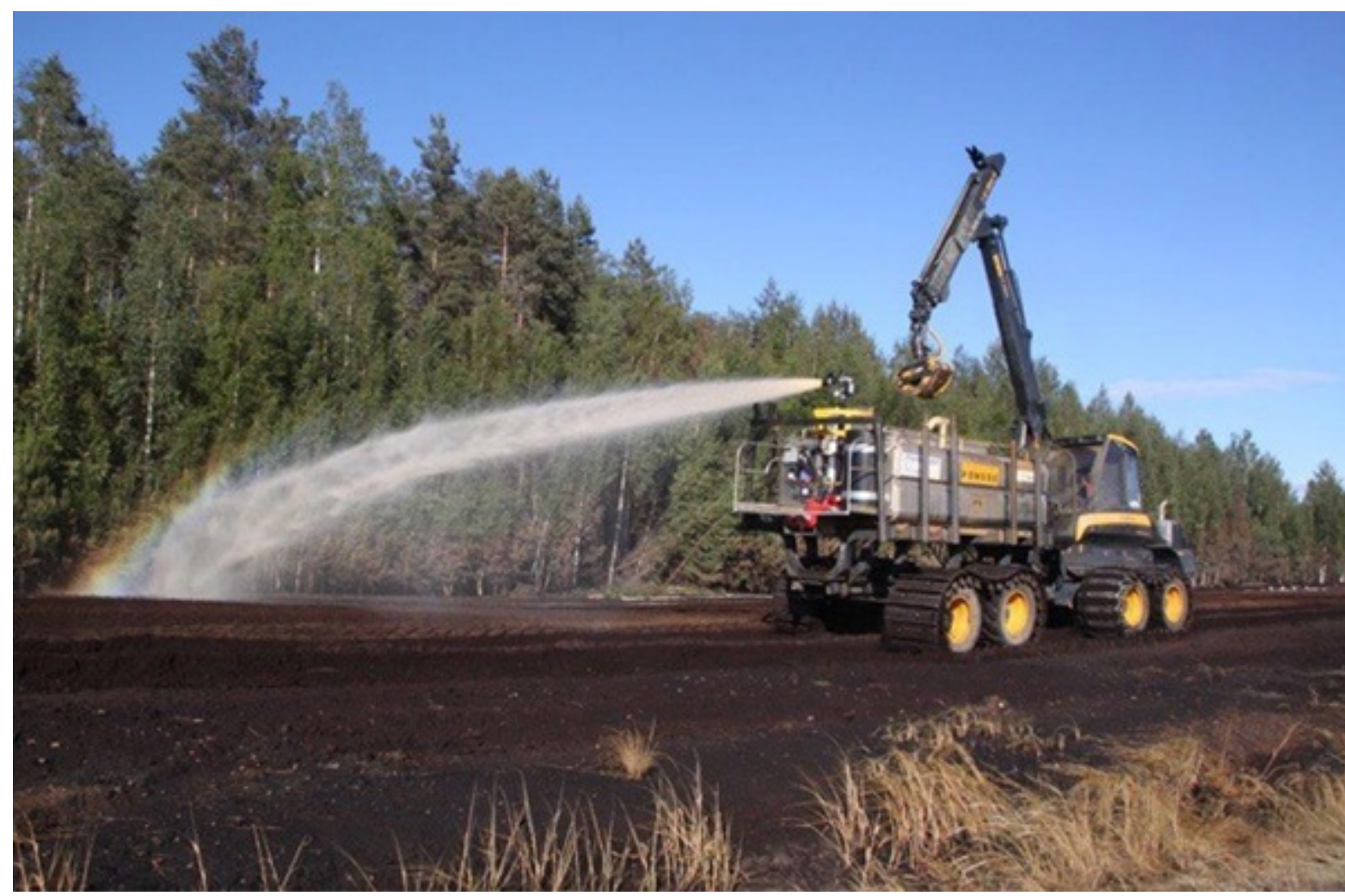

Figure 5.15. Specialised water tank system integrated in forest machines that can drive even in challenging terrain, and it can increase the effect of extinguishing forest fires. It fills up from a pond or a lake nearby, and the tank takes 11000 litres of water. A powerful water cannon allows a large area of operation. The water tank system was used in an exercise in the Taipalsaari bog production area in summer 2019. Photo: Rescue Services of South Savo.

As noted above, wildfires and their subtype of forest fire are only part of the rescue services' operations associated with fires. Understandably, the development of equipment in this field has focused in particular on incidents that pose a danger to life and health. Therefore, the equipment used mainly for construction fires and the small droplet extinguishing technology used within it is not that suitable for forest fires where litter in natural water can cause problems (Kukkonen, 2021). In aerial firefighting, the bottleneck is capacity: scarcity is shared, especially in the case of simultaneous large-scale wildfires. Solutions could include joint procurement of equipment with other Nordic countries, and more flexible cooperation with both the private sector and the defence forces and the border guard (Kukkonen 2021). The need to increase aerial attack capacity is emphasised by the fact that especially in sparsely populated 
areas, problems with the adequacy of firefighting personnel can increase the share of aerial firefighting in forest fire rescue operations (Ruuska, 2020).

In Finland, the population is ageing and moving to growth centres. With climate change set to increase forest fires in the future, a challenging equation is formed: forest fires are laborious and difficult to extinguish, and in the future they will most likely be located in areas with dwindling populations, which makes finding contracted fire brigade staff difficult, for example. In addition, fitness and occupational safety requirements must be taken into account for both contracted and full-time personnel, which further narrows the recruitment base for contracted fire brigades.

The training system for contracted staff is currently being reformed. The starting point is that participation in emergency operations is conditional on the completion of a basic rescue services course. In connection with forest fires, for example, it has been considered whether one could participate in support tasks by completing training designed specifically for those tasks, without completing the basic rescue services course assigned to contracted personnel (Mäkelä, 2020). This would increase the workforce available for forest fires, and at the same time, proper care would be taken to provide training in occupational safety, among other things.

In recent years, more and more information has been gathered on the health risks associated with forest fires. An ongoing study by the Emergency Services Academy Finland has found that in forest fires, firefighting work involves significantly more acute hazards than previously thought, such as in the form of carbon monoxide poisoning and small particles and carcinogens that burden the lungs, heart and blood vessels. In addition, forest fires increase the level of radioactivity at the fire site.

So far, there has been a lack of response to these occupational health and safety risks. Standard equipment for rescue operations, i.e. heavy fire-fighting equipment and compressed air equipment, are too burdensome for forest fires. In the worst-case scenario, many firefighters are involved in forest fires and equipping all of them with the right equipment to extinguish the forest fires is a big cost issue. One future opportunity to increase occupational safety in forest fires is technical applications for the real-time monitoring of biometric parameters (Laitinen, 2021).

All of this puts pressure on the development and utilisation of less labour-intensive extinguishing methods, and on the creation of forest fire spreading patterns that could be utilised to reduce the fire area and required labour. In Finland, this development work is being carried out in a joint project between the Emergency Services Academy Finland, the Finnish Meteorological Institute, the Finnish Forest Centre, Arbonaut Oy, and the North Karelia Rescue Department named 'Spreading patterns of wildfires and processed forest resource data as part of rescue services' situational awareness'. The aim is to create software that models the spread of wildfires for the operational use of rescue services, for example by utilising forest resource data and real-time wind models (MAST, 2021).

As we have seen abroad, one country cannot always extinguish large fires alone. In such situations, the Union Civil Protection Mechanism HNS has been used in the EU region (Host Nation Support). So far, Finland has been more of a giving than receiving party in the mechanism, but naturally cooperation and preparedness will also consider the possibility that Finland receives international assistance and provides support for any required measures (Kansainvälisen avun... 2015). 
Above, future challenges and solutions are structured into a continuum of forest fire prevention, effective forest fire detection, and fire extinguishing. Finally, the change-related challenges identified in both the survey and other sources can be summarised in a different way. Under each of the five sections, a few related factors are mentioned (according to Kukkonen, 2021):

\section{Developing control and modelling}

- Speed and accuracy of fire detection: for example, the development of an automated alarm system based on satellite observation.

- Development of spatial information systems for efficient location of forest fire sites and optimisation of driving routes.

- Use of new technologies: e.g. drones.

- Using forest fire spreading models to assist in the development of firefighting strategy.

- Refinement of the forest fire index to a more local level, and the opportunity to increase preparedness based on this risk information.

\section{Development of equipment and extinguishing technology}

- Developing extinguishing equipment for challenging forest fires.

- Development of situation and command centre operations and sharing resources in the right places according to the situation (Ruuska, 2020).

\section{Taking care of sparsely populated areas}

- The success of recruitment for contracted fire brigades.

- Demographic trends in sparsely populated areas lead to fewer people detecting fires, and the age structure of firefighters becomes higher.

- Both demographic consequences call for the need to develop methods of extinguishing forest fires in such a way as to reduce off-road work (shifting the emphasis to aerial firefighting, use of fire spreading models to control fires).

- Identification of the risks of nature tourism.

\section{Cooperation}

- Adequacy of aerial firefighting equipment and sharing of official resources.

- Nordic and EU cooperation.

- Combining forest sector and rescue service sector know-how.

\section{Strengthening outdoor skills}

- The survey identified education as the main means of reducing the risk of forest fires.

- Multichannel public safety communication: schools, nature tourists and nature tourism entrepreneurs, forest harvester entrepreneurs.

- Raising awareness where there are risks: guidelines for visitors, for example in national parks. 
The previous part is based on documents and surveys that examine forest fires from the outside. How does a forest fire appear in practice?

The case example took place in Southwest Finland in a dry and hot spell in July 2018, when a forest fire started that was large and significant for Finland. It took more than a week to extinguish the fire. The presentation is based on the information entered in the rescue services' resource and incident statistics PRONTO incident report and the email communication with Juha Virto, who was the rescue manager who largely led the rescue operations during the most critical phase of the fire.

The fire alarm came through to the Turku emergency centre on Wednesday 18 July at 14:17. The fire began in a logging area where site preparation was done. At the time of the announcement, the forest was burning in an area of about $20 \mathrm{~m} \times 30 \mathrm{~m}$. The fire spread in part by smouldering under the surface soil. This slowed down the detection of the extent of the fire and made it difficult to extinguish. A significant change occurred as the wind intensified and lifted the fire to become a crown fire. The air temperature was about 30 degrees and the wind speed was 10 metres per second. A forest fire warning had been issued by the Finnish Meteorological Institute, and the value of the forest fire index was high (5.5).

The fire began to spread rapidly towards the settlement. At this point, the firefighting resources were not yet strong enough, and police ordered the immediate evacuation of the surrounding area. The evacuation area had to be expanded later, and a total of 51 people were evacuated from the risk area for two days.

The forest fire operation required extensive cooperation between different authorities. Among other things, aerial firefighting aid was essential. At the beginning of the incident, a helicopter for extinguishing work was requested from the Finnish Maritime Rescue Coordination Centre, but it was engaged in another mission. The helicopter requested from Helsinki was also on a mission. A helicopter from the defence forces was requested. It was estimated that it would reach the destination in about two hours. Through the Regional State Administrative Agency, the Ministry of the Interior was asked to provide firefighting aircraft assistance from Sweden. The Ministry of the Interior's response was that no aircraft could be obtained from Sweden and that it would be worth trying to get commercial aircraft to the destination. However, in the end, they did not have to be used at any point. Rescue departments prefer the state's, i.e. the border guard's and the defence forces' flight extinguishing equipment, because their use is free of charge for the departments. The cost of private helicopters however will be borne by rescue departments (Ruuska, 2020).

Meanwhile, the raging crown fire was still spreading (Fig. 5.16). The aeroplane, which leads aerial firefighting operation (so called bird dog), disengaged the fire in the neighbouring province, and its first task when arriving at Pyhäranta was to provide situational information about the extent of the affected area from the air. The fire area was successfully demarcated but not extinguished - about 10 hours after the helicopters provided by the defence forces and border guard arrived on the scene to join extinguishing and restriction activities on the ground. The challenge was the risk of the fire spreading again due to strong winds and still unburnt areas within the area, for example. At the north/north-east end of the fire area, smoke generation was so heavy that helicopters could not safely fly there. Aerial surveillance of the fire area was 
also performed with drones, but sometimes the perception of the fire area was better from the ground.

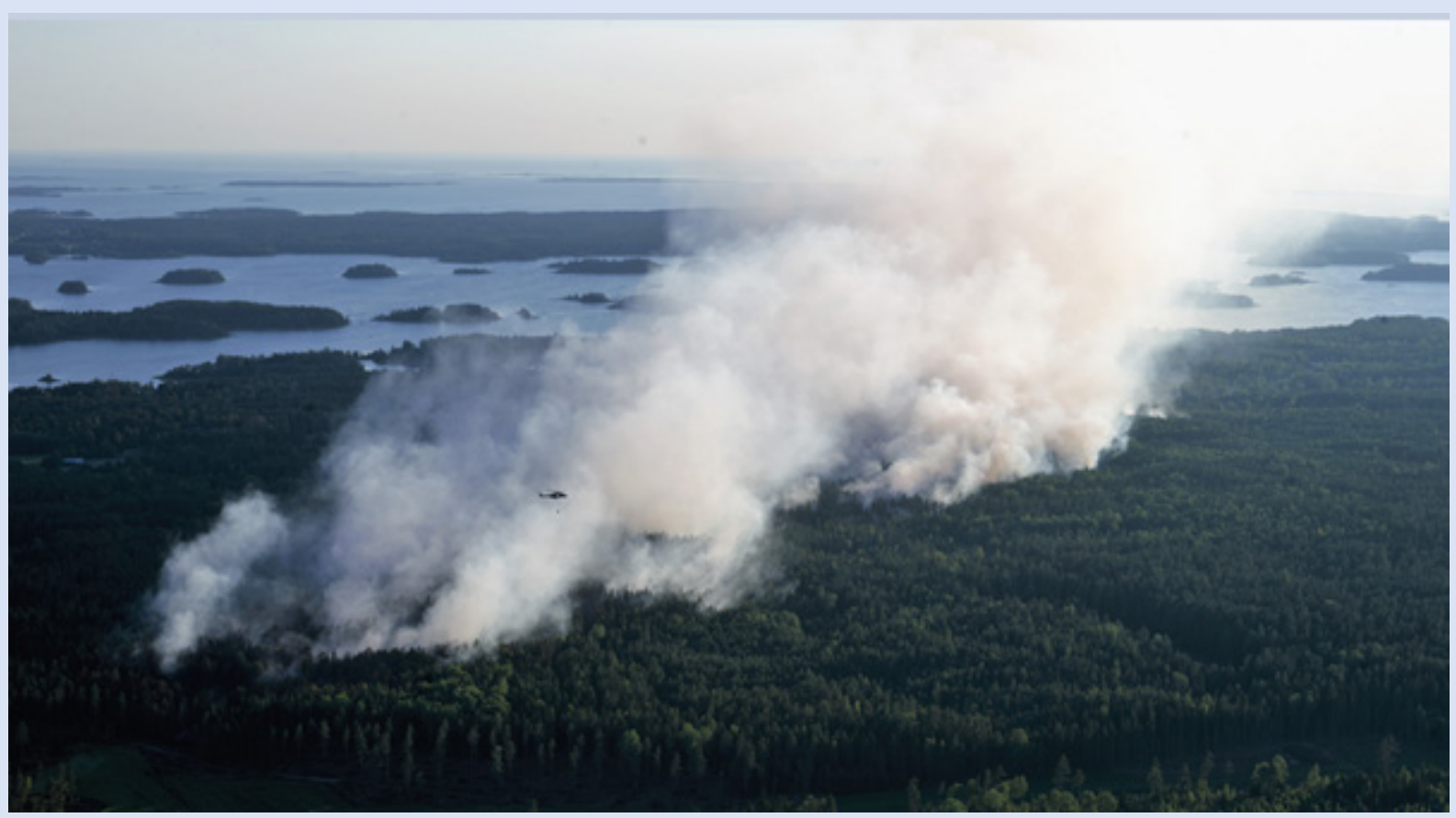

Figure 5.16. This photo illustrates how large a task the Pyhäranta forest fire was. It also demonstrates how widely the smoke spreads out, which can cause severe harm to those who suffer from heart problems or problems with respiration in particular. Forest fires even increase the level of radioactivity at the fire site. Photo: Jouko Anttila.

The Southwest Finland Rescue Department received assistance from four other rescue departments: Satakunta, Kanta-Häme, Western Uusimaa and Pirkanmaa. It is exceptional for one operation to have personnel from so many different rescue departments. Support was received not only in the form of firefighting assistance, but also in situation management. Police monitored air operations and made sure no outside aircraft were flown in the fire area (private or media drones). The police also protected the extinguishing and maintenance activities with traffic control, and in this task the police were supported by voluntary rescue services and the defence forces' civil service. A considerable part of the traffic was involved in transporting water from approximately $1.5 \mathrm{~km}$ away. Contracted fire brigades played a key role in firefighting work, supplying water and other supporting work.

Rescue operations continued for several days without interruption. The fire broke out on Wednesday 18 July 2018, and the fire watch and extinguishing work ended on Thursday 26 July 2018. The rescue operation lasted for a total of nine days. Efforts were made to change the number of firefighting personnel more frequently than usual due to exposure and very severe physical exertion. The conditions were very demanding for the firefighters due to the hot weather, the heat of the fire site, the heavy equipment, the difficult terrain and the long duration of the operation (Fig. 5.17). In addition, gusts of wind, heavy smoke generation, and the transportation of equipment in dense forest complicated the situation. There was a risk of trees falling in the burnt terrain, and the fire that was smouldering in the soil also had to be excavated using shovels. Despite all attempts, excessive shifts could not be avoided, although new firefighting personnel and equipment were constantly alerted, especially in the early stages of the fire. 




Figure 5.17. Firefighters' work in forest fires is extremely burdensome, and extinguishing can take a long time - especially when the fire smoulders deep in the soil. In Pyhäranta, the forest fire rescue operation took nine days. Photo: Esa Urhonen.

The maintenance machinery was rotated around the clock by the authorities, the third sector and entrepreneurs. Catering was provided by the women's departments of the fire brigades, which were later supported by the scout troop. The municipality of Pyhäranta took care of the well-being of evacuees and others in need of support by arranging mental health support and the necessary health care. Residents of the municipality were kept up to date via the Pyhäranta municipality website. The Pyhäranta parish camp centre accommodated those who took part in the extinguishing activities, and together with the municipality, the church organised a moment of calm for those affected by the fire.

One of the key factors in extinguishing the fire was a fire control line about a kilometer long and about 40 meters wide made by private forest entrepreneurs with their forest machinery to prevent the fire from spreading. Large quantities of fuel were needed during the operation, and replenishments were continuously provided. Heavy traffic also placed considerable strain on the roadbeds, which were reinforced with gravel loads.

As can be seen from the above, a serious and large forest fire required the cooperation of many different operators. The estimated total number of people involved in the entire rescue operation was about 950. To support the firefighting operations, a management team was set up, which included representatives of the maintenance team, the police, defence forces, Pyhäranta municipality and Metsähallitus, alongside those who led the rescue operations (Fig. 5.18). The management team held meetings every three hours or so. 


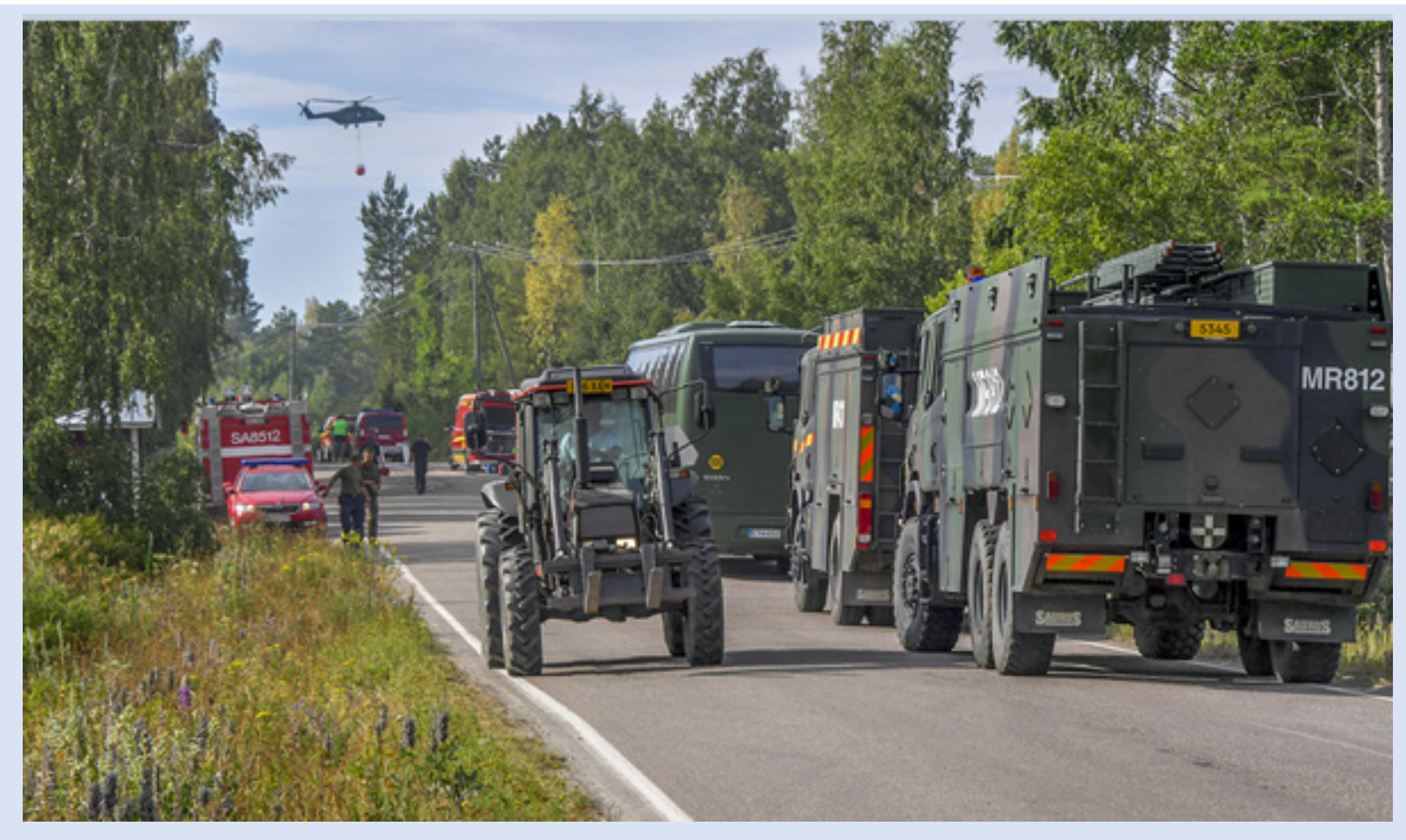

Figure 5.18. A large forest fire requires wide cooperation between many authorities and other actors. In Pyhäranta, the forest fire defence forces took part in evacuation as well as aerial firefighting. Photo: Esa Urhonen.

There was work for the rescue services not only at the fire site, but also at the situation centre at the rescue department's main fire station in Turku. The situation centre provided the necessary resources for the site, made requests for official assistance, prepared emergency reports, mapped the resources of the nearest rescue departments and their availability, and alerted the contracted fire brigades. At the same time, of course, the organisation of all other rescue services' operations had to be taken care of and the adequacy of personnel and equipment for overlapping tasks had to be ensured.

Assessing the extent of the burnt area is understandably challenging. In this case, the size of the burnt area was confirmed to be about 40 hectares. The cost of the damage to the forestry efforts totalled around 410000 euros. In addition, the fire destroyed outbuildings and movable property.

The police conducted an investigation into the cause of the fire at the scene, which later turned into a preliminary investigation due to a suspected crime of negligence. The preliminary police investigation examined, among other things, whether the employees present at a contractor's site had complied with the fire safety instructions in use in their industry and sent by the sawmill that commissioned the logging during the forest fire warning.

On the morning the fire started, the forest machinery operator had noticed a small, smoky spot in the woods at the base of a stone. They stomped on and watered this spot, kept an eye on it while driving lumber, and twice walked to the spot to check on it. The driver informed the landowner living nearby, who went to pour about 100 litres of water onto the smoky terrain. The wildfire that started later in the day was estimated to have started from this same point. (Preliminary Investigation Report of the Southwest Finland Police Department concerning the case, 2). 
The prosecutor made the decision not to prosecute the case. The decision noted that after the smoke was detected, the site had been watered and monitored. The high risk of forest fire was identified in operations. Both Metsähallitus' statement and the firefighters' hearing testified that the amount of water poured on the small smoky area was in principle sufficient, but it is possible that the soil continued to smoulder afterwards. For the same reason, one cannot say for sure how long the fire smouldered - possibly even for days before the fire. As more than one person was operating machinery at the logging site, it was unclear whose activities would have caused the fire. In the end, the prosecutor assessed that the contractor's representatives on site had taken adequate precautions to prevent the forest fire (Western Finland Prosecutor's Office's decision not to prosecute).

Juha Virto, the rescue manager who largely led the rescue operations in the first days, thought afterwards that the role of forest machinery and its operators received too little attention in the large-scale operation. In the management of rescue services, a decision was made to create a demarcation line, which was implemented with the forest machinery. Although the cooperation of firefighters and aerial firefighting was able to stop the fire before that demarcation, it was nevertheless an important and secure line for stopping the fire. The role of contracted staff should also be emphasised: the forest fire, which lasted more than a week, required great effort. Contract personnel participated in rescue and maintenance activities during their summer holidays or after their regular working hours. At the same time, they attended other rescue and first aid missions in the area in their usual manner.

Juha Virto, who has long experience in the rescue service sector, summarises the advantages of the Finnish system in preventing and extinguishing forest fires in four points. The first of these is the structure of the Finnish rescue service; the model formed by full-time and contracted fire brigades and cooperating authorities worked excellently in the Pyhäranta case, for example. Secondly, the forest fire surveillance system works well - and in the future will work even better with the aid of satellite surveillance. Thirdly, thanks to the Finnish emergency centre model, the competent authority can be contacted quickly. As a fourth factor, Virto raises the desire and activity of citizens to report their findings to the emergency centre (Virto, 2021).

\section{References}

Aalto, J., Pirinen, P., Jylhä, K. 2016. New gridded daily climatology of Finland: Permutationbased uncertainty estimates and temporal trends in climate. Journal of Geophysical Research: Atmospheres 121: 3807-3823.

Alueelliset riskiarviot 2018. Sisäministeriö [Regional risk assessments 2018. Ministry of the Interior [In Finnish].] https://intermin.fi/pelastustoimi/varautuminen/kansallinen-riskiarvio

Anderson, W., Cruz, M. G., Fernandes, P., Van Wilgen. B. 2015. A generic, empirical-based model for predicting rate of fire spread in shrublands. International Journal of Wildfire 24: 443-460.

Bradshaw L. S., Deeming J. E., Burgan R. E., Cohen J. D. 1983. The 1978 national fire-danger rating system: technical documentation. General Technical Report INT-169, USDA Forest Service, Intermountain Forest and Range Experiment Station: Ogden, UT. 44 pp.

Chandler, C., Cheney, P., Thomas, P., Trabaud, L., Williams, D. 1983. Fire in forestry. Bd. 1. John Wiley and Sons, New York. 450 pp.

Coen, J. L. 2013. Modeling wildland fires: a description of the Coupled Atmosphere-Wildland Fire Environment Model (CAWFE). NCAR earth system laboratory, mesoscale and 
microscale meteorology division. National center for atmospheric research, Boulder, Colorado. 38 pp.

De Groot, W. J. 1987. Interpreting the Canadian forest fire weather index (FWI) system. In: Proceedings of the Fourth Central Region Fire Weather Committee Scientific and Technical Seminar, 2 April 1987, Winnipeg, Manitoba. Canadian Forestry Service, Northern Forestry Centre, Edmonton, Alberta, 3-14.

De Groot, W. J., Goldhammer, J. G., Keenan, T., Brady, M. A., Lynham, T. J., Justice, C. O., Csiszar, I. A., O'Loughlin, K. 2006. Developing a global early warning system for wildland fires. In: Proceedings of the V International Conference on Forest Fire Research, 27-30 November 2006, Coimbra (Viegas, D. X. (ed.)), Elsevier. 12 pp.

Deeming J. E., Burgan R. E., Cohen J. D. 1977. The National fire-danger rating system - 1978. General Technical Report INT-39, USDA Forest Service, Intermountain Forest and Range Experiment Station: Ogden, UT. 66 pp.

Dimitrakopoulos, A.P., Bemmerzouk, A.M., Mitsopoulos, I.D. 2011. Evaluation of the Canadian fire weather index system in an eastern Mediterranean environment. Meteorological Applications 18: 83-93.

Dowdy A. J., Mills G. A., Finkele K., de Groot W. 2009. Australian fire weather as represented by the McArthur Forest Fire Danger Index and the Canadian Forest Fire Weather Index. CAWCR Technical Report 10, Centre for Australian Weather and Climate Research. 84 pp.

Encinas, L. H., White, S. H., Del Rey, A. M., Sánchez, G. R. 2007. Modelling forest fire spread using hexagonal cellular automata. Applied mathematical modelling 31: 1213-1227.

EU:n pelastuspalvelumekanismin on vastattava yhä monimuotoisempiin uhkiin. Sisäministeriö [The EU Civil Protection Mechanism must respond to increasingly complex threats. $\begin{array}{lllll}\text { Ministry of the Interior } & \text { [In } & \text { Finnish].] }\end{array}$ https://intermin.fi/eu2019fi/ohjelma/pelastuspalvelumekanismi

Finney, M. A., 2004. FARSITE: Fire Area Simulator - model development and evaluation. United States Department of Agriculture. Forest Service. Rocky Mountain Research Station. Research Paper RMRS-RP-4 Revised. 52 pp.

Fiorucci, P., Gaetani, F., Minciardi, R., 2008. Development and application of a system for dynamic wildfire risk assessment in Italy. Environmental Modelling \& Software 23: 690702.

Ghisu, T., Arca, B., Pellizzaro, G., Duce, P. 2014. A level-set algorithm for simulating wildfire spread. CMES, vol 102. no.1, 83-102. Computer Modeling in Engineering \& Sciences 102: 83-102.

Giglio, L., Schroeder, W., Justice, C. O. 2016. The collection 6 MODIS active fire detection algorithm and fire products. Remote Sensing of Environment 178: 31-41.

Heikinheimo, M., Venäläinen, A., Tourula, T. 1998. A soil moisture index for the assessment of forest fire potential in the boreal zone. In: Proceedings of the International Symposium on Applied Agrometeorology and Agroclimatology (Volos, Greece), Office for Official Publication of the European Commission (Luxembourg), Dalezios, N.R. (ed.), EUR 18328COST 77, 79, 711. 549-555.

Hiemstra, C. A., Liston, G. E., Pielke Sr., R. A., Birkenheuer, D. L., Albers, S. C. 2006. Comparing Local Analysis and Prediction System (LAPS) assimilations with independent observations. Weather and Forecasting 21: 1024-1040.

Hirsch, K. G. 1996. Canadian Forest Fire Behavior Prediction (FBP) System: user's guide. Nat. Resour. Can., Can. For. Serv., Northwest Reg., North. For. Cent., Edmonton, Alberta. Special Report 7. Natural Resources Canada, Canadian Forest Service, Northern Forestry Centre, Edmonton, Alberta. Special Report. 122 pp.

Hyttinen, H. 2020. Sammutussäiliön käyttö metsäpaloissa. Poliisiammattikorkeakoulun opinnäytetyö Pelastusalan päällystötutkintoon (AMK). 54 pp. [Use of Specialised Water 
Tank System for Extinguishing Forest Fires. Police University College thesis, Fire Officer's Degree

(UAS)

[In

Finnish].] https://www.theseus.fi/bitstream/handle/10024/348101/Hyttinen_Heli.pdf?sequence=4\&is Allowed $=\mathrm{y}$

Johnston, P., Milne, G., Kelso, J. 2006. A heat transfer simulation model for wildfire spread. Forest Ecology and Management 234.

Kainuun alueellinen riskiarvio 2018. 35 pp. [Kainuu regional risk assessment 2018 [In Finnish].] https://intermin.fi/documents/1410869/12562948/Kainuu.pdf/205a87da-405c2740-e78e-1d8d772053aa/Kainuu.pdf

Kallio, H. 2018. Metsäpalon vaara rikosvastuun näkökulmasta. Ympäristöjuridiikka 39: 29-51

[Danger of forest fire from the perspective of criminal liability. Environmental Law [In Finnish].]

Kansainvälisen avun vastaanottojärjestelyt luonnon ja ihmisen aiheuttamissa suuronnettomuustilanteissa Suomessa 2015. Sisäministeriö, Helsinki. 31 pp. [Arrangements for receiving international assistance in natural and man-made disaster situations in Finland in 2015. Ministry of the Interior [In Finnish].] https://julkaisut.valtioneuvosto.fi/bitstream/handle/10024/78913/Kansainv\%c3\%a4lisen\% 20avun\%20vastaanottoj\%c3\%a4rjestelyt.pdf?sequence=1\&isAllowed=y

Kansallinen riskiarvio 2018. Sisäinen turvallisuus. Sisäministeriö. 74 pp. [National risk assessment 2018. Internal security. Ministry of the Interior [In Finnish].] https://julkaisut.valtioneuvosto.fi/bitstream/handle/10024/161332/5_2019_Kansallinen\%2 Oriskiarvio.pdf

Ketola, J. 2018. Hevonkuusessa palaa isosti - Tilastollinen selvitys kesän 2018 metsäpalojen leviämisestä. Pelastusopisto, Kuopio. 83 pp. [There is a big fire in the middle of nowhere Statistical report on the spread of forest fires in the summer of 2018. Emergency Services Academy Finland [In Finnish].] http://info.smedu.fi/kirjasto/Sarja_D/D6_2018.pdf

Ketola, J., Kokki, E. 2018. Finnish Rescue Services' Pocket Statistics 2013-2017. Pelastusopisto - Emergency Services Academy Finland, Kuopio. 37 pp. http://info.smedu.fi/kirjasto/Sarja_D/D3_2018.pdf

Keski-Suomen alueellinen riskiarvio 2018. 54 pp. [Central Finland regional risk assessment 2018 [In Finnish].] https://intermin.fi/documents/1410869/12562948/KeskiSuomi.pdf/1bfd8f9f-1256-77e4-7b91-f93842e0d5d7/Keski-Suomi.pdf

Kolstela, J. 2020. Metsäpalon leviämisen mallintaminen Suomessa. Pro gradu, Itä-Suomen yliopisto, Maantiede. 58 pp. [Modeling forest fire spread in Finland. University of Eastern Finland, Degree Programme of Geography. Master's thesis [In Finnish].] https://erepo.uef.fi/handle/123456789/22919

Kukkonen, M. 2021. Metsäsektorin ja pelastusalan käsityksiä metsäpaloista. Lapin Ammattikorkeakoulu, Rovaniemi. 60 pp. [Perceptions of forest sector and rescue service sector about forest fires. Lapland University of Applied Sciences [In Finnish].] https://www.lapinamk.fi/loader.aspx?id=18c1bbbf-078e-4009-a4c8-99ddd6047a50

Lapin pelastuslaitoksen alueellinen riskiarvio 2018. 22 pp. [Lapland Rescue Department' regional risk assessment [In https://oikeusministerio.fi/documents/1410869/12562948/Lappi.pdf/09e89a96-8597-c01732d3-d4c1202c0b81/Lappi.pdf.pdf

Lapin pelastuslaitoksen palvelutasopäätös 2020-2023. 55 pp. [Lapland Rescue Department service standard decision 2020-2023 [In Finnish].] https://enontekio.fi/web2017/wpcontent/uploads/2017/02/Liite-4-Palvelutasop\%C3\%A4\%C3\%A4t\%C3\%B6s-2020-2023Lappi-kh-30.8.2019.pdf

Lehtimäki, M., Mäkelä, P. 2018. Tuottamukselliset tulipalot ja niitä koskevat ilmoitusmenettelyt. Pelastusopisto, Kuopio. 117 pp. [Negligent fires and related reporting 
procedures. Emergency Services Academy Finland [In Finnish].] http://info.smedu.fi/kirjasto/Sarja B/B3 2018.pdf

Mallet, V., Keyes, D. E., Fenderell, F. E. 2008. Modeling wildland fire propagation with level set methods. Computers \& Mathematics with Applications 57: 1089-1101.

MAST - Maastopalojen leviämismallit ja jalostettu metsävaratieto osana pelastustoimen tilannekuvan muodostamista. Hanke-esittely Pelastusopiston verkkosivuilla. 2021 [Spreading patterns of wildfires and processed forest resource data as part of rescue services' situational awareness. Project presentation on the Emergency Services Academy Finland website [In Finnish].] https://www.pelastusopisto.fi/tutkimus-ja-tietopalvelut/tkipalvelut/hankkeet/maastopalojen-leviamismallit-ja-jalostettu-metsavaratieto-osanapelastustoimen-tilannekuvan-muodostamista/

Matthews S. 2009. A comparison of fire danger rating systems for use in forests. The Australian Meteorological and Oceanographic Journal 58: 41-48.

Monteith J. L. 1981. Evaporation and surface temperature. Quarterly Journal of the Royal Meteorological Society 107: 1-27.

Mäkelä, P. 2020. Pelastusopiston sopimushenkilöstön koulutusjärjestelmä. Pelastustoiminnan peruskurssia koskeva kysely: kvantitativiviset tulokset. Pelastusopisto, Kuopio. 32 pp. [Emergency Services Academy Finland contracted staff training system. Rescue services basic course survey: quantitative results. Emergency Services Academy Finland [In Finnish].] https://www.pelastusopisto.fi/wp-content/uploads/Pelastustoiminnanperuskurssia-koskeva-kysely-kvantitatiiviset-tulokset.pdf

Mäkelä, P. 2021. Pelastuslaitosten ilmoitusmenettelyjen ja yhteistyöryhmien kehittämishanke - Loppuraportti. Pelastusopisto, Kuopio. 112 pp. [Rescue authorities' obligation to report to police and cooperation between authorities - Final report. Emergency Services Academy Finland [In Finnish with abstract in English].] http://info.smedu.fi/kirjasto/Sarja_B/B1_2021.pdf

Nesterov, V. G. 1949. Combustibility of the forest and methods for its determination. USSR State Industry Press, Colesbumaga, Moscow. 76 pp.

Nieminen, A. (toim./ed.) 2020. Metsäpaloriskin ennakointi metsätöissä. Tapio Palvelut Oy. 36 pp. [Forest fire risk forecasting in forestry work [In Finnish].] https://tapio.fi/wpcontent/uploads/2020/06/Metsäpaloriskin-ennakointi-metsätöissä-opas-Tapio-2020.pdf

Oulu-Koillismaan pelastuslaitoksen palvelutasopäätös 2017-2020. Pelastuslain (379/2011) 28-29 §:n mukainen palvelutasopäätös 2021-2024. 64 pp. [Service standard decision of the Oulu-Koillismaa Rescue Department 2017-2020. Service standard decision 2021-2024 pursuant to sections 28-29 of the Rescue Act (379/2011) [In Finnish].] https://ii.oncloudos.com/kuulutus/20201686.PDF

Padilla, M., Vega-Garcia, C. 2011. On the comparative importance of fire danger rating indices and their integration with spatial and temporal variables for predicting daily human-caused fire occurrence in Span. International Journal of Wildland Fire 20: 46-58.

Parisien, M.-A., Kafka, V., Hirsch, K. G., Todd. J. B., Lavoie, S. G., Maczek, P. D. 2005. Mapping wildfire susceptibility with the BURN-P3 simulation model. Natural Resources Canada, Canadian Forest Service, Northern Forestry Centre, Edmonton, Alberta. Information report NOR-X-405. 36 pp.

Pastor, E., Zárate, E., Planas, J., Arnaldos, J. 2003. Mathematical models and calculation systems for the study of wildland fire behaviour. Progress in Energy and Combustion Science 29: 139-153.

Pearce, H. G., Clifford, V. 2008. Fire weather and climate of New Zealand. New Zealand Journal of Forestry 53: 13-18.

Pieni opas sopimuspalokunnista ja pelastustoimen vapaaehtoistoiminnasta. Suomen sopimuspalokuntien liitto. $40 \mathrm{pp}$. [A small guide to contracted fire brigades and rescue 
volunteering. Federation of Finnish Contracted Fire Brigades [In Finnish].] https://sspl.fi/images/OPASPANKKI/2019/SSPL_pieni_opas.pdf

Pirkanmaan pelastustoimen palvelutasopäätöksen tarkistaminen 2020-2021. 49 pp. [Service standard decision revision of the Pirkanmaa rescue service 2020-2021 [In Finnish].] https://tampere.cloudnc.fi/download/noname/\%7B5f09277b-3b01-47f3-b833$45 \mathrm{c} 6410013 \mathrm{cc} \% 7 \mathrm{D} / 3831172$

Plank, S., Fuchs, E.-M., Frey, C. 2017. A Fully Automatic Instantaneous Fire Hotspot Detection Processor Based on AVHRR Imagery-A TIMELINE Thematic Processor. Remote Sensing 9: 30.

Pohjois-Savon alueellinen riskiarvio 2018. 42 pp. [North Savo Regional Risk Assessment 2018 [In $\quad$ Finnish].] https://intermin.fi/documents/1410869/12562948/PohjoisSavo.pdf/7fe36263-8d6d-14e1-be70-1d70fefc00a1/Pohjois-Savo.pdf

Pohjois-Savon pelastustoimen palvelutasopäätös 2020-2023. 108 pp. [Service standard decision of the North Savo rescue service 2020-2023 [In Finnish].] http://pspelastuslaitos.fi/js/upload/1608290316_Palvelutasopäätös\%202021-2023.pdf

Richards, G. D. 1990. An elliptical growth model of forest fire fronts and its numerical solution. International Journal for Numerical Methods in Engineering 30: 113-1149.

Rossa, C. G., Fernandes, P. 2018. Empirical modeling of fire spread rate in no-wind and noslope conditions. Forest Science 64: 358-370.

Ruuska, R. 2020. Suomen maasto- ja metsäpalojen torjuntajärjestelmän kehittäminen. Case vertailu Suomen ja Ruotsin järjestelmistä. Diplomityö, Lappeenrannan-Lahden teknillinen yliopisto LUT. $70 \mathrm{pp}$. [Development of the Finnish wildfire control system. A case comparison of Finland's and Sweden's systems. Master's thesis, Lappeenranta-Lahti $\begin{array}{lllll}\text { University of } & \text { Technology } & \text { LUT } & \text { [In } & \text { Finnish].] }\end{array}$ https://lutpub.lut.fi/bitstream/handle/10024/161949/Diplomity\%C3\%B6\%20(Ruuska\%202 020).pdf? sequence $=1$

Salonen, M. 2020. Pelastusrikkomuksen perusteet. Pelastusrikkomuksen vähäinen käyttö ja sen syyt. Poliisiammattikorkeakoulun opinnäytetyö Pelastusalan päällystötutkintoon (AMK). 79 pp. [Basics of Rescue Violation. Limited use of Rescue Violation and its causes. Police University College thesis, Fire Officer's Degree (UAS) [In Finnish].] https://www.theseus.fi/bitstream/handle/10024/346022/Salonen_Maarit.pdf?sequence=2\&i sAllowed $=y$

San-Miguel-Ayanz, J., Carlson, J. D., Alexander M., Tolhurst K., Morgan G., Sneeuwjagt, R., Dudley, M. 2003. Current methods to assess fire danger potential. In: Wildland Fire Danger Estimation and Mapping. The Role of Remote Sensing Data (Chuvieco, E. (ed.)). World Scientific Publishing, Singapore, 21-61.

Schlobohm, P., Brain, J. 2002. Gaining an understanding of the national fire danger rating system. National wildfire coordinating group. NWCG fire danger working team. $72 \mathrm{pp}$.

Schroeder, W., Oliva, P., Giglio, L,. Csiszar, I. A. 2014. The New VIIRS $375 \mathrm{~m}$ active fire detection data product: Algorithm description and initial assessment. Remote Sensing of Environment 143: 85-96.

Soares, J., Sofiev, M., Hakkarainen, J. 2015. Uncertainties of wild-land fires emission in AQMEII phase 2 case study. Atmospheric Environment 115: 361-370.

Stocks, B. J., Cahoon, D. R., Levine, J. S., Cofer, W. R., Lynham, T. J. 1996. Major 1992 fires in Central and Eastern Siberia: Satellite and fire danger measurements. In: Fire in ecosystems of boreal Eurasia (Goldammer, J. G., and Furyaev, V. V. (eds.)). Kluwer, Dordrecht, 139-150.

Stratton, R. D. 2008. Assessing the effectiveness of landscape fuel treatments on fire growth and behavior in southern Utah. USDA Forest Service General Techical Report, PSW-GTR189, 309-319. 
Sullivan, A. L., Ellis, P. F., Knight, I. K. 2003. A review of radiant heat flux models used in bushfire applications. International Journal of Wildland Fire 12: 101-110.

Turner, J. A., Lawson, B. D. 1978. Weather in the Canadian Forest Fire Danger Rating System. A user guide to national standards and practices. Fisheries and Environment Canada, Canadian Forest Service, Pacific Forest Research Centre, Victoria, BC. Information Report BC-X-177. 40 pp.

Tymstra, C., Bryce, R. W., Wotton, B. M., Taylor, S. W., Armitage, O. B. 2010. Development and structure of Prometheus: the Canadian Wildland Fire Growth Simulation Model. Natural Resources Canada, Canadian Forest Service, Northern Forestry Centre, Information report NOR-X-417. Edmonton, Alberta. 88 pp. Nat. Resour. Can., For. Serv., North. For. Cent., Edmonton, AB. Inf. Rep. NOR-X-417.

Vajda, A., Venäläinen, A., Suomi, I., Junila, P., Mäkelä, H. 2014. Assessment of forest fire danger in a boreal forest environment: description and evaluation of the operational system applied in Finland. Meteorological Applications 21: 879-887.

Venäläinen, A., Heikinheimo, M. 2003. The Finnish forest fire index calculation system. In: Early Warning Systems for Natural Disaster Reduction (Zschau, J., and Kuppers, A. (eds)). Springer, Berlin 645-648.

Viegas, D. X., Piñol, J., Viegas, M. T., Ogaya, R. 2001. Estimating live fine fuels moisture content using meteorologically-based indices. International Journal of Wildland Fire 10: 223-240.

Wagenbrenner, N. S., Forthofer, J. M., Page, W. G., Butler, B. W. 2019. Development and evaluation of a Reynolds-averaged Navier-Stokes solver in WindNinja for operational wildland fire applications. Atmosphere 10: 672.

Van Wagner, C. E. 1987. Development and structure of the Canadian Forest Fire Weather Index System. Forestry Technical Report 35, Canadian Forest Service, Petawawa Forest Experiment Station, Chalk River. 36 pp.

Wiggins, E. B., Soja, A. J., Gargulinski, E., Halliday, H. S., Pierce, R. B., Schmidt, C. C., Nowak, J. B., DiGangi, J. P., Diskin, G. S., Katich, J. M., Perring, A. E., Schwarz, J. P., Anderson, B. E., Chen, G., Crosbie, E. C., Jordan, C., Robinson, C. E., Sanchez, K. J., Shingler, T. J., Shook, M., Thornhill, K. L., Winstead, E. L., Ziemba, L. D., Moore, R. H. 2020. High temporal resolution satellite observations of fire radiative power reveal link between fire behavior and aerosol and gas emissions. Geophysical Research Letters 47: e2020GL090707.

Xu, W., Wooster, M. J., He, J., Zhang, T. 2020. First study of Sentinel-3 SLSTR active fire detection and FRP retrieval: Night-time algorithm enhancements and global intercomparison to MODIS and VIIRS AF products. Remote Sensing of Environment 248: 111947.

Yang, W., Gardelin, M., Olsson, J., Bosshard, T. 2015. Multi-variable bias correction: Application of forest fire risk in present and future climate in Sweden. Natural Hazards and Earth System Sciences 15: 2037-2057.

\section{Other unpublished sources}

Laitinen, J. 2021. Comments on occupational health and safety factors of extinguishing forest fires. E-mail to Päivi Mäkelä dated the 15th of March 2021. Ph.D., docent Juha Laitinen specializes in research related to rescuers' exposure.

Virto, J. 2021. Comments on the forest fire of Pyhäranta in July 2018. E-mail to Päivi Mäkelä dated the 4th of February 2021. Responses of Juha Virto, the rescue manager of Southwest Finland's Rescue Department, regarding the additional questions concerning the Pyhäranta forest fire. 


\section{Wildfires are a significant source of black carbon}

\section{Tero Partanen}

The particular interest of this chapter is in Fennoscandian wildfires and their black carbon (BC) emissions (Fig. 6.1). This chapter concentrates on a case study that estimates the impact of BC caused by wildfires in the Fennoscandian region on the environment. Of particular interest is to determine the deposition (i.e. fallout) of $\mathrm{BC}$ over the Arctic region because of its albedo reducing and melting effects on snow and ice. The $\mathrm{BC}$ concentration in the air is also of interest due to its harmful effects on health. The estimate is made for 2018, arising from a simulation based on MODIS remotely sensed fire data as the input for IS4FIRES system driven by the SILAM atmospheric dispersion model. Furthermore, in order to put the $\mathrm{BC}$ deposition and concentration into a reasonable perspective, they are compared against those of globally emitted wildfire and anthropogenic BC. In addition, this chapter also shortly overviews possible future prospects of wildfire events as well as the effects of wildfire emissions on health.

\section{Forest fires are the largest source of black carbon in the Arctic - Fennoscandian fires have local effects on the environment and air quality}

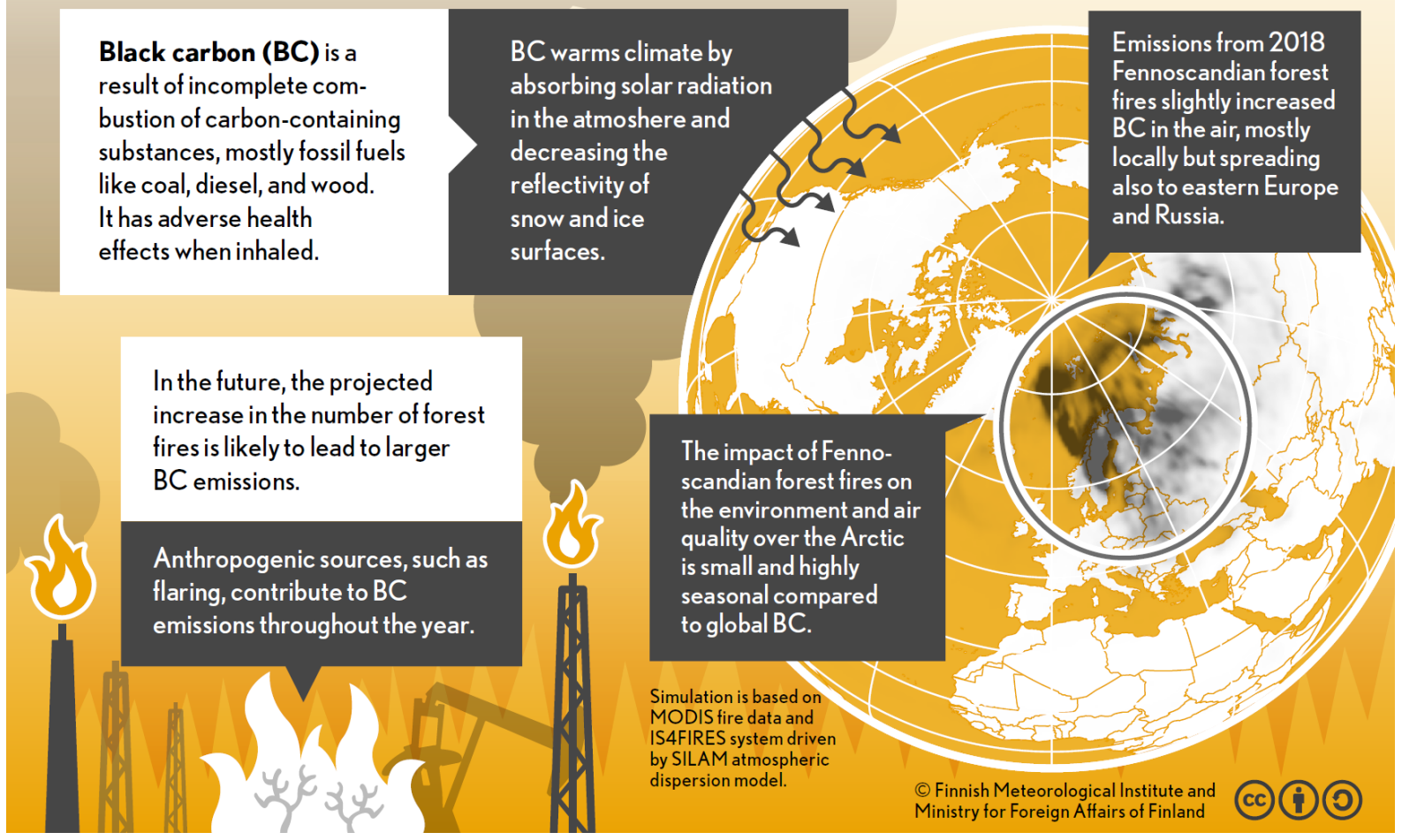

Figure 6.1. Infographics 'Forest fires are the largest source of black carbon in the Arctic Fennoscandian fires have local effects on the environment and air quality' summarising the main concepts and findings of the chapter.

\subsection{Wildfires as the source of black carbon under climate change}

Organic carbon (OC) and $\mathrm{BC}$ are both fractions of fine particles which together compose a group called carbonaceous aerosols. BC, more commonly called soot (even though soot also contains some OC), is the light-absorbing component of carbonaceous aerosols. An in-depth 
discussion of these definitions can be found in (Andreae and Gelencsér, 2006; Buseck et al., 2012). BC is an air pollutant, which is considered not only harmful to the environment and living organisms, but also has a significant impact on the climate by warming the atmosphere. Apart from BC from lightning-induced wildfires (or, less commonly, geological or astronomical events), $\mathrm{BC}$ is primarily emitted into the atmosphere by human activities. It is a result of incomplete combustion of carbon-containing substances produced mostly by the burning of fossil fuels, largely coal, diesel and wood. The major global BC emission contributors based on Sims et al. (2015) are open biomass burning with 36\%, residential cooking, heating and illumination with $25 \%$, transport with $19 \%$, and industry with $19 \%$. The regional shares of annual BC emissions from Bond et al. (2013) are Asia 39\%, Africa 24\%, Latin America 14\%, Europe 6\%, EECCA 6\%, North America 5\%, Pacific 4\%, and Middle East $2 \%$ with total emissions of $7540 \mathrm{Gg} / \mathrm{yr}$. Carbonaceous emissions are expected to be reduced worldwide (but not necessarily regionally) due to new, less polluting technology along with a shift away from the burning of coal and wood in the residential sector (Streets et al., 2004).

$\mathrm{BC}$ is the most harmful component of carbonaceous aerosols. It may have very adverse effects on health when inhaled and on the environment when deposited, and it is also considered one of the worst (possibly the worst [Jacobson, 2001]) global climate warming contributors after $\mathrm{CO}_{2}$. While $\mathrm{CO}_{2}$ is a gaseous compound that can linger in the atmosphere for up to millennia, $\mathrm{BC}$ only remains in the atmosphere for up to a few weeks before depositing to the ground with rain or snow. During the time BC stays in the atmosphere, it can be transported over large distances, even across the globe. Both greenhouse gases in general and $\mathrm{BC}$ aerosols absorb heat energy and thus have a warming effect on the earth's climate. In addition, $\mathrm{CO}_{2}$ and the other greenhouse gases prevent infrared (heat) radiation from escaping to space. BC aerosols, or light-absorbing carbonaceous aerosols in general, are microscopic in size and dark in colour, and thus have significantly high heat-trapping power. Consequently, $\mathrm{BC}$ has a remarkable ability to heat up the atmosphere by effectively capturing heat energy from the sun. Furthermore, for the same reason, in cases where there are BC deposits on an ice or snow field, it affects the albedo of the surface and thereby reduces the reflectance of sunlight, that is, it increases the field's capability to absorb heat, which in turn causes melting of the field. Due to the short residence time in the air, $\mathrm{BC}$ emission reductions could have a rapid effect on slowing down global warming.

It is broadly assumed that climate warming (Cook et al., 2016) results in an increasing number of wildfires (see e.g. Lozano et al., [2017] and references therein) and, in turn, wildfire emissions contribute to climate warming (Knorr et al., 2016). Thus, climate warming and wildfires form a positive feedback system by boosting each other and causing an increasingly detrimental effect on the environment, property and health. Climate warming increases wildfire risk by raising the average temperature of the atmosphere, intensifying drought, and stretching the length of the dry season. Wildfires, for their part, emit into the atmosphere primarily atmosphere-warming carbon dioxide $\left(\mathrm{CO}_{2}\right)$ among other greenhouse gases, and carbonaceous particulate matter (PM) among other aerosols. Wildfires also wipe out forests that would otherwise absorb $\mathrm{CO}_{2}$ from the ambient air, thus accelerating the warming of the climate.

The most likely source of ignition of wildfires is human activity and it is estimated that about $90 \%$ of all wildfires are human induced (Lobert et al., 1999, see chapter 2). The causes are various, such as agriculture, arson, and carelessness. In general, wildfires are unpredictable. Human behaviour contributes greatly to the ignition, suppression, and prevention of wildfires. The risk and uncontrollability of fires increase with drought and winds. Changes in precipitation patterns affect vegetation growth, which in turn has an impact on the spatial and 
temporal patterns of wildfires. Global wildfire incidence may be closely linked to climate, land use and population density. Global wildfire trends may vary due to changes in global precipitation, temperature and anthropogenic behaviour, i.e. fire ignition and suppression. However, it may also vary from era to era where one of the drivers overpowers one another (Marlon et al., 2008; Pechony and Shindell, 2010). For example, Pechony and Shindell (2010) uses climate and fire modelling coupled with estimates of the changes in land cover and population to project future fires. As a conclusion of the paper, it is found that fires were globally driven by precipitation during pre-industrial times. After that, fires shifted to be driven by human activities, which is still the case, and will next shift to temperature-driven fires (i.e. climate) this century. Globally, the increase in population density has a strong effect on reducing fire activity by increasing fire suppression. However, not even population growth together with increasing precipitation and ever-declining vegetation can stop the anticipated upcoming rapid rise in fire activity in the middle of this century, which will be driven by an unprecedented temperature rise accompanied by intensifying droughts. In addition, an important factor in fire emission dispersion is an emission plume injection height, which has a major effect on how emissions will be transported and distributed in the atmosphere over the globe. The future schemes shown in (Veira et al., 2016) suggest higher stability in the troposphere, which lowers planetary boundary height, and thus more effective long-range transport of smoke plumes.

In general, predictions of the future behaviour of climate change have been narrowed down to a few realistic possibilities. There are four different future climate change schemes, the socalled representative concentration pathway (RCP) scenarios anticipated by (IPCC, 2014), which represent four different variations in greenhouse gas concentrations. According to these scenarios, the year 2100 will have four possible radiative forcing outcomes, namely $+2.6,+4.5$, +6.0 , and +8.5 in units of watts per square metre. Radiative forcing is a measure of the net change in the earth's incoming and outgoing solar radiation flux due to greenhouse gases as forcing agents. These four positive values, which indicate that the planet is warming up, represent predicted increments in radiative forcing by 2100 relative to pre-industrial times, i.e. prior to 1750. The four emission scenarios are denoted by RCPx, with $\mathrm{x}=2.6,4.5,6.0$ or 8.5, where $\mathrm{x}$ directly indicates the radiative forcing value. The expected RCP scenario will presumably be somewhere between the two extreme alternatives: RCP2.6 and RCP8.5. The former represents a desirable scenario where the strictest measures are taken to reduce greenhouse gas emissions, whereas the latter represents an undesirable scenario where no measures whatsoever are taken. In the RCP2.6 scenario, CO2 emissions peak around 2020 and start declining considerably thereafter, and somewhere after 2080 CO2 absorption exceeds emissions. The RCP4.5 and RCP6.0 are intermediary scenarios which both peak at some point and stabilise to certain values by 2100 . The RCP8.5 is the only one of the scenarios where CO2 flux is still increasing in 2100. Global temperature increments in the RCP scenarios vary from about one to four and a half degrees Celsius by 2100 . Only for the RCP2.6 scenario, the temperature is expected to stay within the limits set by the 2015 Paris Agreement, which aims to limit global warming within two degrees Celsius with respect to pre-industrial temperatures. Nearly all countries in the world are signatories to the agreement. It should be noted that the RCPs are only simplified scenarios for the future, as they do not take into account socioeconomic effects. The Shared Socioeconomic Pathway (SSP) scenarios, on the other hand, include those effects. The SSPs, which comprise five different possible socio-economic futures, provide a new, more complex set of scenarios to estimate greenhouse gas emissions up to 2100 . 
In general, the amount of $\mathrm{BC}$ emitted by wildfires is directly proportional to the number of them. Therefore, in the future, a change in the number of fires is also directly proportional to a change in the amount of $\mathrm{BC}$ emissions.

\subsection{Black carbon is harmful to health}

The World Health Organization (WHO) estimates that about $90 \%$ of the world's population breathe polluted outdoor and household air (WHO, 2018). Outdoor air pollution is assumed to cause a few million premature deaths a year worldwide. For example, Lelieveld et al. (2015) estimates the number of deaths to be about 3.3 million and WHO (2018) estimates that in 2016, the number was approximately 4.2 million. Air pollution is a mixture of particulate and gaseous matter, which is harmful to health. It is considered a significant factor in respiratory and cardiovascular morbidity and mortality (Samek, 2016; Thurston et al. 2016; Hamanaka and Mutlu, 2018). PM components of air pollution are known to have a stronger effect on health than gaseous ones (Hamanaka and Mutlu, 2018). Exposure to fine PM can be associated with various adverse health effects (Pope and Dockery, 2006, WHO, 2013). However, different PM components, due to their varying particle sizes and toxicities, are not equally important in causing health problems (WHO, 2013). There is however no clear consensus on which components would be more toxic than the others (Adams et al., 2015). Exposure to PM2.5 can be directly manifested as eye and respiratory tract irritation. Long-term exposure to PM2.5 increases mortality from lung cancer and heart disease. WHO safety limits for PM2.5 are 10 $\mu \mathrm{g} / \mathrm{m}^{3}$ annual mean or $25 \mu \mathrm{g} / \mathrm{m}^{3}$ 24-hour mean. In addition, air pollution exposure, in general, can be related not only to physical health effects but even psychological effects; it can, for example, increase the risk of depressive symptoms (Lim et al., 2012) and, as a result, lead to suicide deaths (Szyszkowicz et al., 2010). Carbonaceous aerosols, i.e. BC and OC, typically exist as particles smaller than a micrometre in diameter. Thus, $\mathrm{BC}$ is counted as a component of the so-called fine PM, referring to particles with diameters of less than 2.5 micrometres. This category of PM is the most harmful to human health due to its particle size that enables deeper penetration into the lung when inhaled. BC therefore poses a severe risk to human health when exposed to high concentrations in the air for long periods. BC particles can pass into the blood system through the lungs, and, in the case of long-term exposure, may consequently cause both respiratory and cardiovascular problems. It is concluded that $\mathrm{BC}$ is not a major toxic component of PM, but rather a carrier of all sorts of harmful chemicals to the lungs (WHO, 2013).

A recent review article (Johnson et al., 2020) combined 28 studies that exploit multiple simulation models to estimate PM emission exposure from wildfires, including a relatively recent study by (Kollanus et al., 2016) on health effects in Europe caused by PM2.5 emissions from wildfires simulated by means of the SILAM model. According to Kollanus at al. (2016), which takes into account the major part of Europe, one may expect an overall increase in mortality in the order of about a thousand people each year in Europe due to wildfire emitted fine PM. The study investigated mortality in Europe in 2005 and 2008 as a result of fine PM from wildfires. The study assessed premature deaths due to wildfire emitted PM2.5 in four geographic regions of Europe: Northern, Eastern, Western and Southern Europe. The Northern Europe region comprised Denmark, Finland, Norway and Sweden. In both study years, the mortality peaks in the summer months, as expected, and is negligible in Northern Europe in comparison with all other regions where it is much more important. The result is consistent with the findings of (Johnston et al., 2012), who estimated that wildfire emissions may cause as many as a few hundred thousand premature deaths annually worldwide. It is estimated in the paper that during the period 1997-2006, an average of 339000 people died each year globally as a result of wildfire smoke exposure. About four-fifths of the deaths were associated with 
chronic exposure and one-fifth to sporadic exposure. Mortality is much higher in poorer countries, especially in sub-Saharan Africa and Southeast Asia. During this period, the estimated annual average PM2.5 concentration from wildfires in the Fennoscandia area was relatively low, not exceeding the amount of $1 \mu \mathrm{g} / \mathrm{m}^{3}$, and thus does not contribute strongly to deaths in the area.

\subsection{Assessment of black carbon emissions from Fennoscandian wildfires}

There are three major sources of black carbon in the Arctic. Arguably the largest source of BC are forest fires, which can be very intense in the second part of summer. The buoyant fire plumes reach high in the free troposphere and, in extreme cases, to the tropopause and lower stratosphere. The troposphere is the lowest layer in the atmosphere, extending from the surface to roughly $10 \mathrm{~km}$, and the stratosphere is the next layer above the troposphere, reaching about $50 \mathrm{~km}$. High injection facilitates the long life of the smoke plumes in the air. The primary anthropogenic source of BC in the Arctic is gas flaring. Large oil production facilities in Russia, Norway and Canada are significant sources of $\mathrm{BC}$ throughout the year. Finally, other anthropogenic combustion sources, including power generation, industry and domestic combustion, also operate throughout the year but tend to have peak emission in wintertime. The climate forcing of $\mathrm{BC}$ in the Arctic arises from two main reasons: 1) degradation of atmospheric optical thickness due to presence of absorbing aerosols in the air, and 2) deposition on the snow darkening its surface and reducing the surface albedo. The impact is the highest for bright surfaces, such as ice and snow. In this regard, long-range transport of fire plumes and wintertime flaring pose the main threat.

$\mathrm{BC}$ emissions from wildfires in Fennoscandia and, separately, both wildfires and anthropogenic sources across the globe are estimated here for 2018. The methodology builds upon the FMI tools IS4FIRES (Integrated System for wild-land fires, http://is4fires.fmi.fi) and SILAM (System for Integrated modeLling of Atmospheric coMposition, http://silam.fmi.fi). The emission assessment arises from the IS4FIRES system, which is a near-real time arrangement to evaluate fire emission plumes steered by the SILAM model. IS4FIRES is part of the FMI global-to-local forecasting and assessment framework. With the SILAM chemistry transport model as the core, the framework incorporates several standard input flows and embedded or stand-alone emission models. IS4FIRES provides the information on active fires to the SILAM internal fire emission source. It is a hybrid system combining the top-down and bottom-up approaches. The system utilises the active fires information of MODIS instruments, which is the real-time bottom-up component of the system: it compiles emission maps from observed fires analysing them one-by-one. The system can also be used for retrospective and, to some extent, anticipatory assessments.

The two identical Moderate-resolution Imaging Spectroradiometer (MODIS) instruments are onboard NASA's Terra and Aqua near-earth orbiting satellites. These two earth-observing satellites are revolving around the earth in near-circular orbits at an altitude of about $700 \mathrm{~km}$ above the earth's surface, with a revolution time of 99 minutes, which comes to 15 revolutions a day per satellite. So, these satellites travel at an orbital speed of about $7.5 \mathrm{~km} / \mathrm{s}$. They are near-polar orbiting satellites, thus enabling global coverage. The exact polar orbit would pass exactly over both the north and south poles. The Terra and Aqua satellites circulate less than 10 degrees off the exact polar orbit. They also follow the so-called sun-synchronous orbit, meaning that their daily overflights over any given point always happen at about the same local time. The cross-track observation width of MODIS is about $2330 \mathrm{~km}$. The MODIS instruments have a spatial resolution of about one kilometre squared at nadir, which expands towards the 
edges of the scan taking a rectangular shape of about 10 -fold size. Together, the instruments scan nearly all locations over the whole globe up to four times a day. The MODIS instrument is able to catch data in 36 different electromagnetic radiation wavelengths emitted by the earth's surface, with wavelengths spanning between 0.4 to 14 micrometres; that is, the observed wavelengths range from visible light to thermal-infrared radiation. A major portion of the fire radiation comes from infrared light. At fire temperatures, in accordance with Wien's Displacement Law, the thermal radiation spectrum peaks at a wavelength of around 4 micrometres. However, gases like water vapour and carbon dioxide make the atmosphere highly opaque to infrared light. Fortunately, there are a couple of nearly transparent but narrow infrared gaps in the atmosphere. Conveniently one of these atmospheric windows lies between 3 to 5 micrometre wavelengths. So, the approximate wavelength of 4 micrometres at which the fire radiation is most intense falls nicely in this window. The fire-observing satellite sensors like MODIS remote-sensing instruments exploit this gap. Another exploited gap, where background temperatures peak, lies around the wavelength of 11 micrometres.

IS4FRIES exploits MODIS level 2 MOD14 (Terra) and MYD14 (Aqua) fire product datasets to locate fires and evaluate their emissions. To illustrate the data, Figure 6.2 depicts MODIS FRP observations across the globe in 2018. In IS4FIRES, permanent, stationary fire radiative power (FRP) sources such as factories, power plants and oil refineries observed by satellites are taken into account and omitted. If FRP is repeatedly observed somewhere for more than 50 days a year for more than six years, the location is flagged out. The product of the IS4FIRESSILAM system has global coverage and incorporates the BC-related processes, including its emission model (IS4FIRES), transport, ageing and deposition (SILAM). The specific source of the fire and flaring data will be the MODIS satellite products, in combination with ATSR/AVHRR hot-spot data for the past. The fire data is converted into BC emissions following the IS4FIRES hybrid emission assessment procedure: top-down emission inverseproblem solution followed by bottom-up inventory calculation.

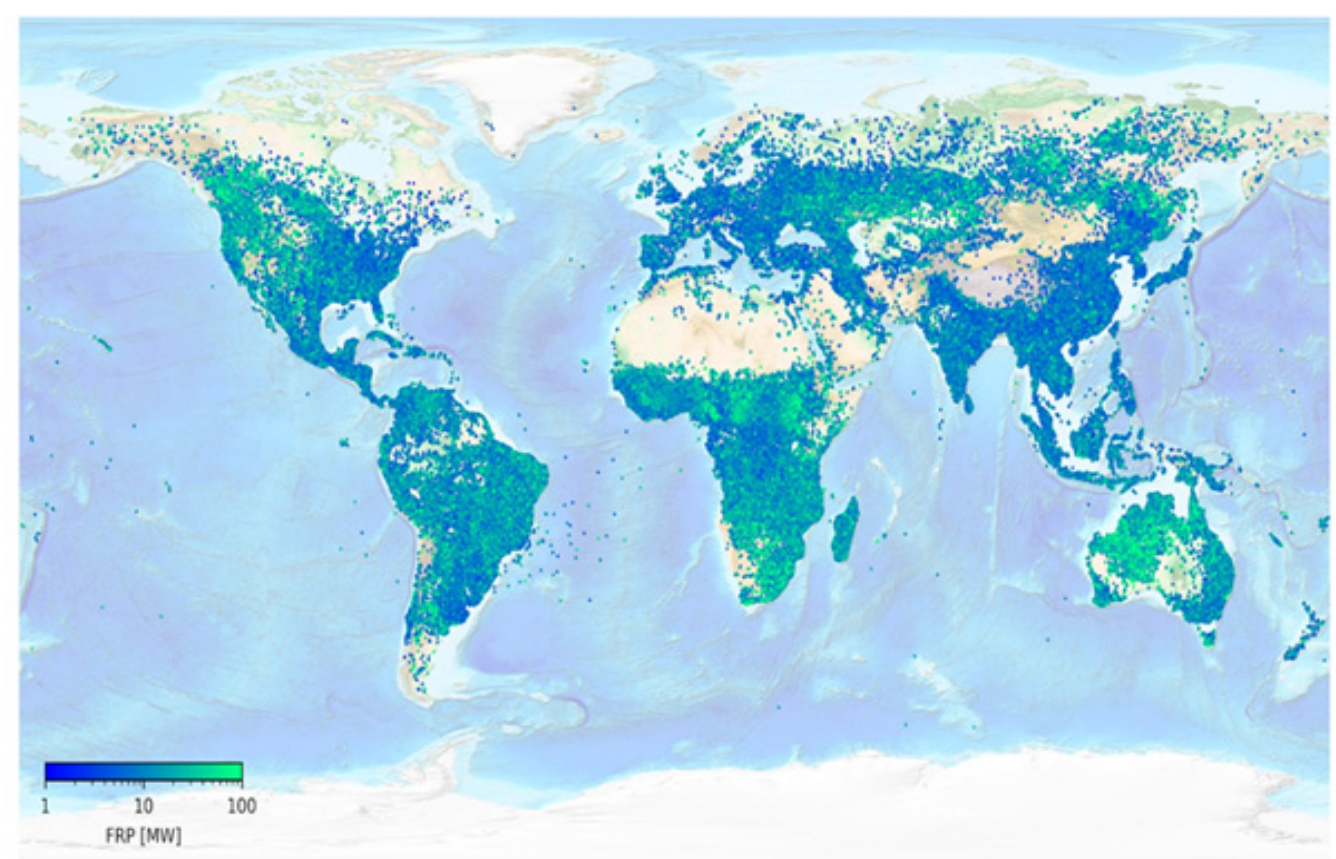

Figure 6.2. Locations and values of MODIS-observed Fire Radiative Power (FRP, in units of MW) across the globe in 2018. 
Due to unusual heat and drought in northern Europe in 2018, there were an exceptional number of wildfires in the areas belonging to Fennoscandia. Therefore, the BC produced by the Fennoscandian wildfires during that year presumably represents a sort of upper limit for the emissions rather than average emissions. This makes 2018 an ideal year to estimate the real future risk of $\mathrm{BC}$ emissions from Fennoscandian wildfires on Fennoscandia, the Arctic and the entire northern hemisphere.

Next, SILAM results for BC depositions and concentrations for wildfire BC emissions from Fennoscandia and the world are represented here as figures of the simulation output. Because of the interest in the impact of $\mathrm{BC}$ on health, all concentration results are ground-level concentrations. In the simulation, the Fennoscandian region was quite accurately delimited by shape of actual Fennoscandia (Fig. 6.3). This is essential since in the case of an overly simple approximation, e.g. one in which the smallest rectangular area encloses all the perimeters of the precise Fennoscandian peninsula, wildfires in Eastern Europe would dominate. The simulation period with hourly time steps was 12 months, starting from 1 January 2018 and ending on 31 December 2018. Simulations adopted ERA5 meteorological reanalysis data provided by the European Centre for Medium-Range Weather Forecasts (ECMWF). SILAM uses emission coefficients for biomass burning provided by (Akagi et al., 2011). It is assumed in SILAM that all fire-emitted PM is PM2.5. The Fennoscandian region consists mainly of boreal forest. Unfortunately, Akagi et al. (2011) does not directly provide an emission coefficient value for BC from boreal forest fires. The fraction of BC in PM2.5 estimated based on tropical and extratropical forest fires is about $6 \%$ (Akagi et al., 2011). In the results of the BC emitted by Fennoscandian wildfires, the observed FRP is converted to PM2.5 fire emissions, from which the $\mathrm{BC}$ fraction is assumed to be $5 \%$ of total emissions. Global anthropogenic emissions of elemental carbon (EC) arise from the burning of carbon-containing substances. Contributions of open fires are excluded from the anthropogenic EC emissions. EC is taken as identical to BC in the results. In the results, the year is split into four seasons of three months each. The seasons are defined as follows: winter: January, February and December; spring: March, April and May; summer: June, July and August; autumn: September, October and November. The winter season is composed of the months of the same calendar year. Figure 6.3 illustrates locations of hot pixels in Fennoscandia in 2018 and their Fire Radiative Power (FRP) values detected by the MODIS instruments onboard the Terra and Aqua satellites.

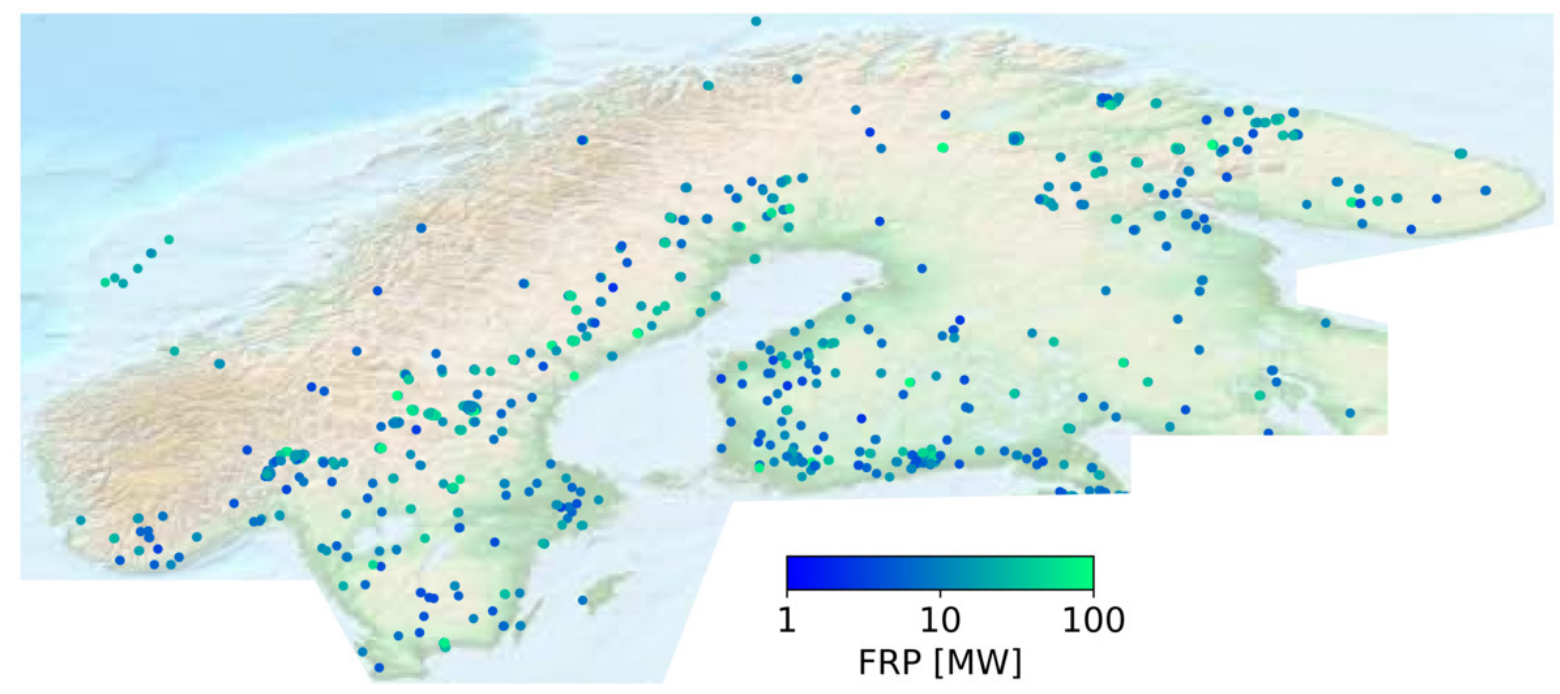

Figure 6.3. Locations and values of MODIS-observed Fire Radiative Power (FRP, in units of MW) in Fennoscandia in 2018. 
In the simulation, $\mathrm{BC}$ emission concentration in the air and deposition on the ground from wildfires are inferred by the IS4FIRES-SILAM system from MODIS fire data, see Figures 6.2 and 6.3 for FRP observations across the globe and in Fennoscandia, respectively.

Figure 6.4 represents $\mathrm{BC}$ deposition originating from wildfires in Fennoscandia in the northern hemisphere for 2018. The deposition arises from the cumulative sum of wet and dry depositions. The seasonal results (Fig. 6.4a-d) of the $\mathrm{BC}$ depositions are treated independently from each other, but the annual result (Fig. 6.4e) arises from a cumulative contribution of all annual data. The BC emissions from Fennoscandian wildfires are strongly seasonal, occurring mainly in summer, and the area affected by these emissions are quite limited. The practically indistinguishable Figures $6.4 \mathrm{c}$ and $6.4 \mathrm{e}$ show clearly that the annual deposition originates fully from the summer season. This combined with the fact that the sea ice and snow cover in the northern hemisphere are at their minimum during the summer season, minimises the impact of $\mathrm{BC}$ deposition from Fennoscandian wildfires on them. To a large extent, practically only the Arctic Ocean is frozen, and Greenland is covered by snow throughout the year (Fig. 6.5a-b for the summer ice and snow situation in the northern hemisphere, respectively). The ice fraction and snow depth depicted in the Figure 6.5 are from ECMWF ERA5 reanalysis data. The north polar ice cap is at its maximum in March and minimum in September (Perovich at al., 2019). The highest densities of BC deposition barely reach Greenland and the edge of the ice cap located north-east of Greenland. This can be seen from the comparison between Figure 6.4e and Figure 6.5a. The Figure 6.5b shows that apart from Greenland and the Svalbard and Novaya Zemlya archipelagos, the whole of the northern hemisphere is snowless during the summer season. The highest load of BC spreads out towards the east of the north-east coast of Greenland and fallout over Svalbard and Novaya Zemlya. 


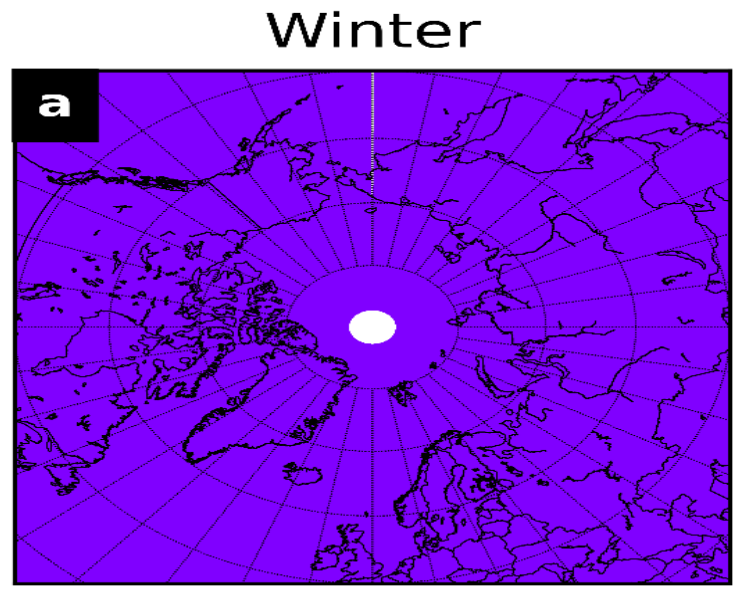

Summer
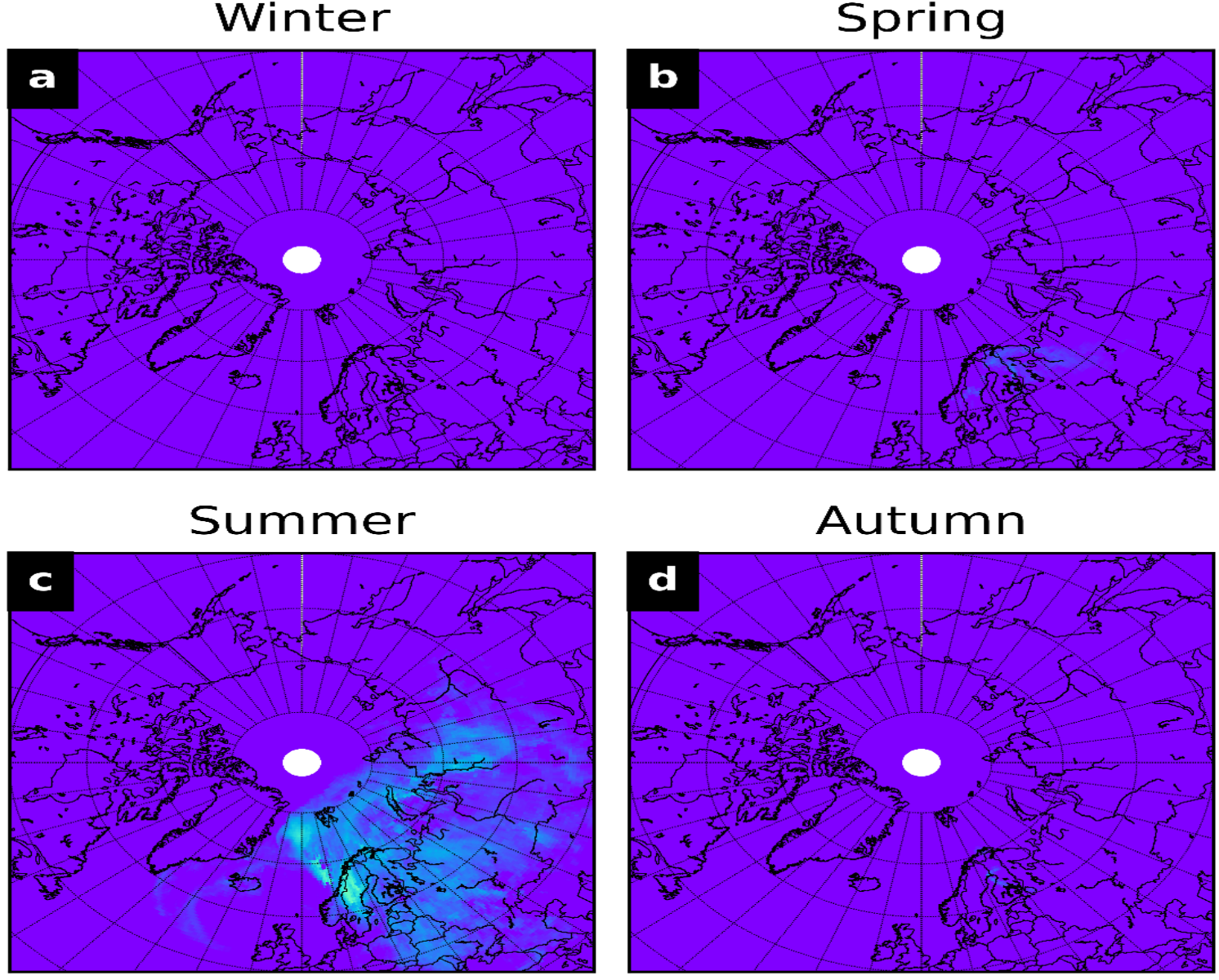

Autumn

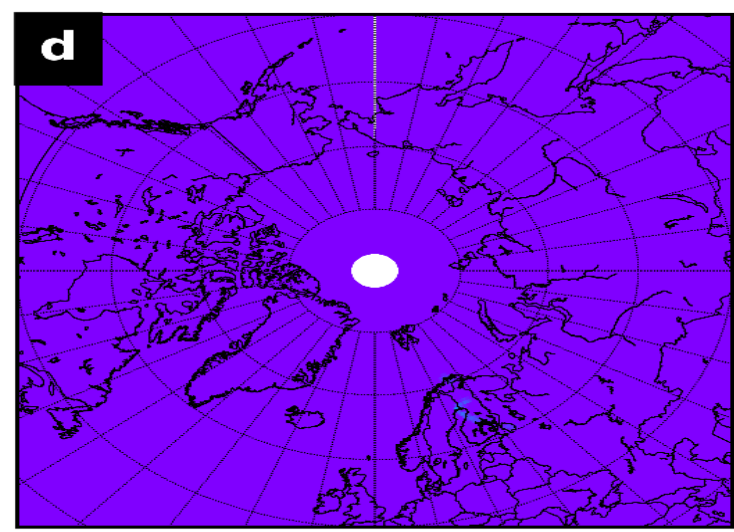

2018

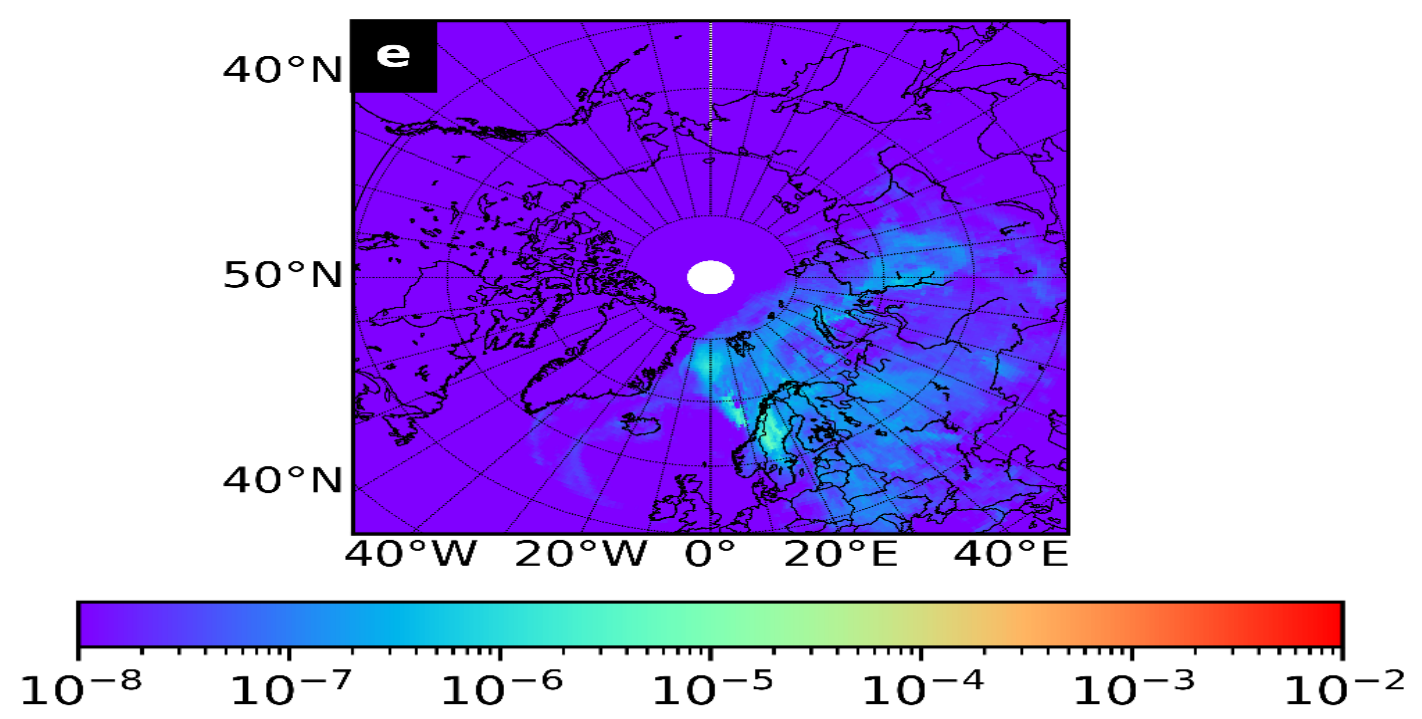

Figure 6.4. Seasonal (panels a-d) and annual (panel e) accumulation of BC deposition (in units of $\mathrm{kg} / \mathrm{m}^{2}$ ) from Fennoscandian wildfires in 2018. 

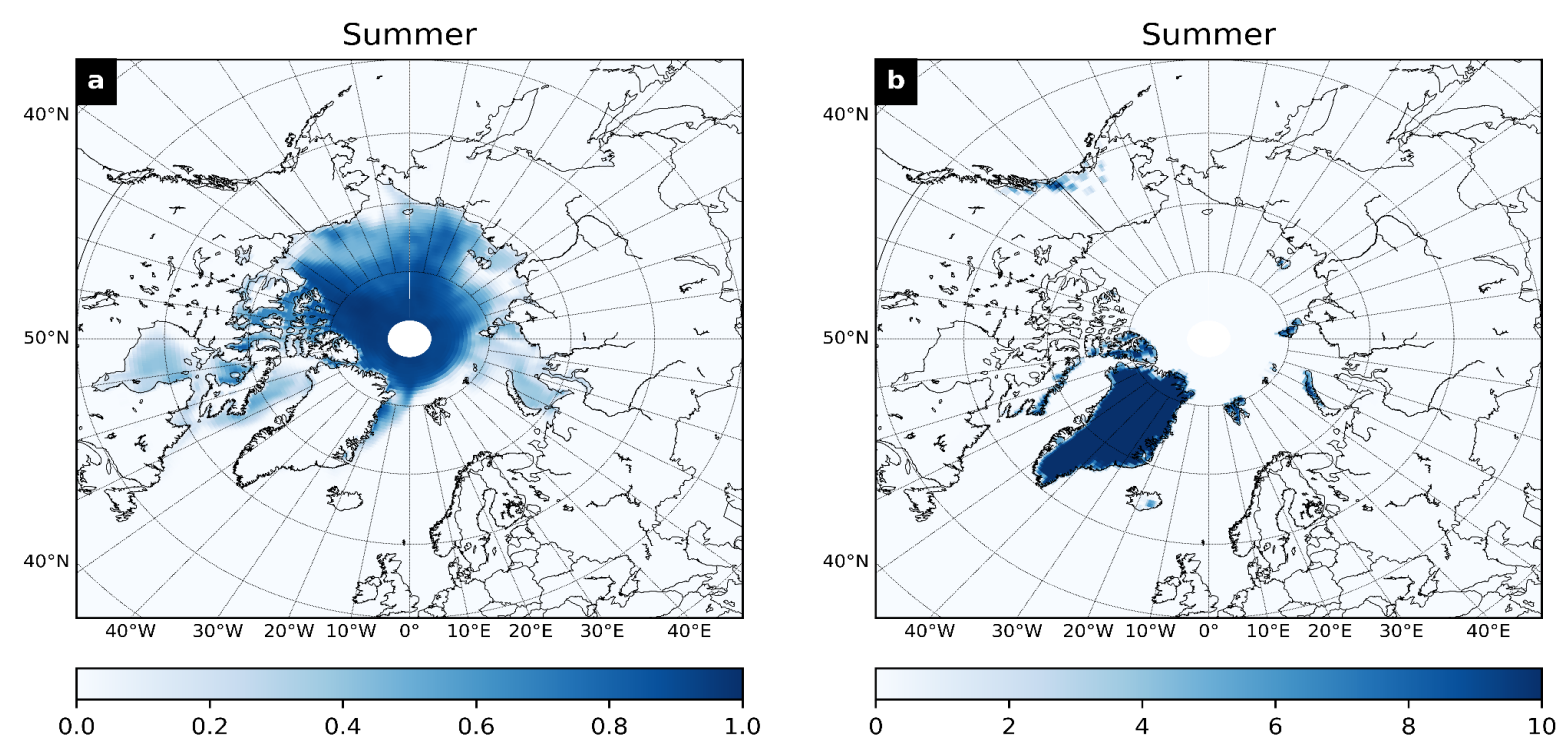

Figure 6.5. The panel a depicts the ice fraction on a scale of 0 to 1 , where 0 is no ice and 1 is full ice, and the panel $b$ depicts the snow depth in metres. The two panels show the average values over the summer season.

Wildfires in Fennoscandia mostly occur during the summer and autumn seasons, but in 2018 specifically, the most polluting ones occurred in July in Sweden. Figure 6.6 represents the seasonal and annual averages of $\mathrm{BC}$ concentrations in the air originating from Fennoscandian wildfires in 2018. The concentrations (Fig. 6.6a-d) are averaged within seasons and (Fig. 6.6e) represent the annual average. Naturally, the concentrations and deposition have very similar patterns. The highest BC concentrations occur during the summer season (Fig. 6.6c). BC particles are transported over long distances dispersed over vast areas. A more detailed look at the simulation data reveals that the strongest emissions originate from Central Sweden in about mid-July and near the Finnish border on the Kola Peninsula at the beginning of the last third of July. The source areas for these emissions can also be deduced from Figures. 6.4c and 6.6c. The strongest smoke plumes originate from the Swedish fires. By following the total column $\mathrm{BC}$ concentration (i.e. vertical Integral of BC concentration), at first, the plumes begin to move towards the north-west, reaching the west coast of Greenland in about four days and then turn to east, spreading almost all over Russia in about three days and finally twirling back over south-eastern and eastern Europe about a week and a half after the fires broke out. The groundlevel concentration dispersion is similar in character but narrower in scope. In general, the simulations suggest that the impact of BC emissions from Fennoscandian wildfires seem to be more of a local than a global issue. 



\section{8}

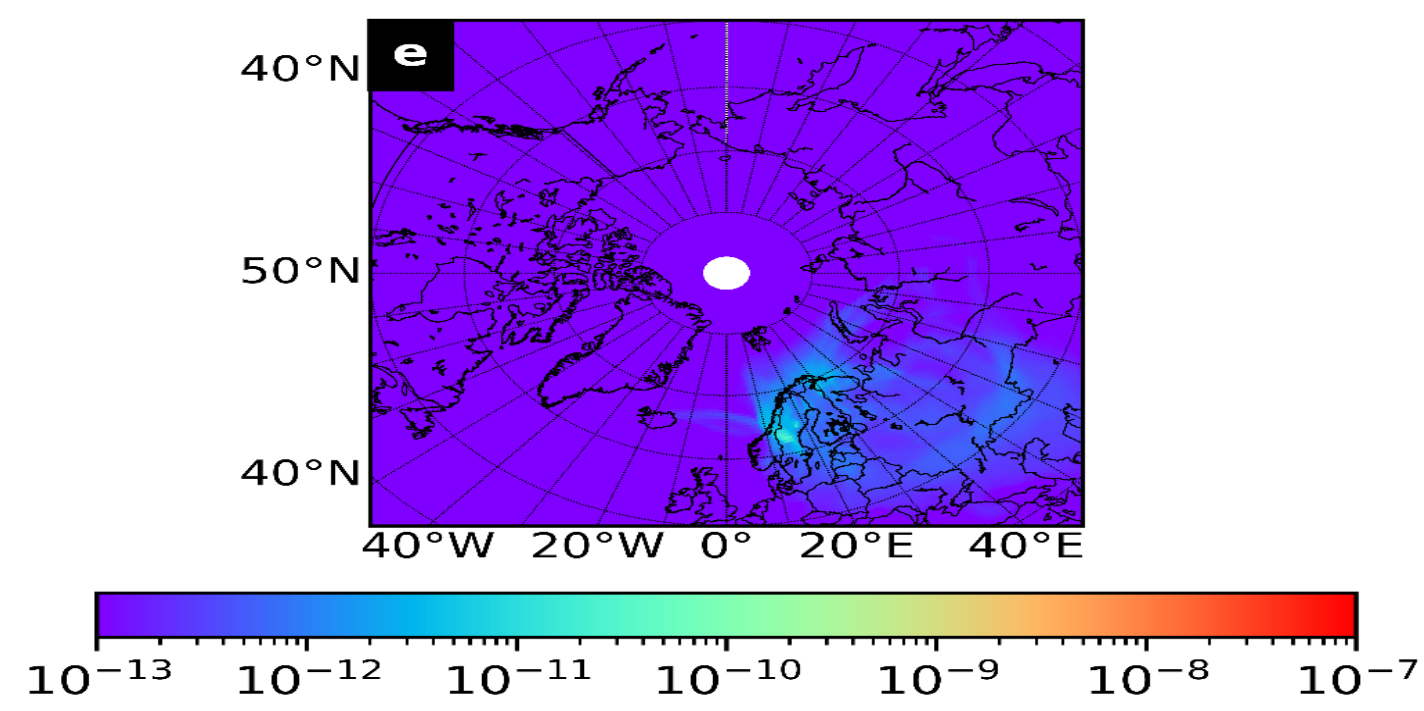

Figure 6.6. Seasonal (panels a-d) and annual (panel e) averages of BC concentrations in units of $\mathrm{kg} / \mathrm{m}^{3}$ from Fennoscandian wildfires in 2018.

Fennoscandian wildfire-induced $\mathrm{BC}$ is also compared to global wildfire emissions of $\mathrm{BC}$ and to global anthropogenic emissions of BC. In a similar fashion to Figure 6.4, Figure 6.7 shows the deposition of BC from all wildfires around the world in the northern hemisphere for 2018 . As can be seen in the panels a-d of Figure 6.7 showing the seasonal accumulation of BC and in 
panel e of the same figure, the impact of global wildfire emissions is much stronger even in the northern hemisphere than the effect of Fennoscandian fires alone. Also, like in the case of Fennoscandian fires, the deposition of BC from global wildfires in the northern hemisphere occurs mainly during the summer season. Within the Arctic Circle, the highest depositions fall into Siberia and somewhere around the East Siberian Sea and New Siberian Island. Because of the differences in the fire seasons, wildfires occur across the globe throughout the year. As seen by the comparison between Figures 6.4 and 6.5, Fennoscandian wildfires do not have an effect on Arctic ice and snow, whereas, as seen by the comparison between Figures 6.7 and 6.5, wildfires globally have a constant impact on them. As for air quality, Figure 6.8 shows, in a similar fashion to Figure 6.6, the averages of $\mathrm{BC}$ concentrations from all wildfires around the world in the northern hemisphere for 2018. The highest concentrations of BC occur in the summer season (Fig. 6.8c). This is expected because global wildfire occurrences tend to be highest in August-September when the wildfires of both hemispheres contribute the most. BC concentration and deposition from wildfires are at their lowest during the winter season. The global minimum for wildfire occurrence is in February. 

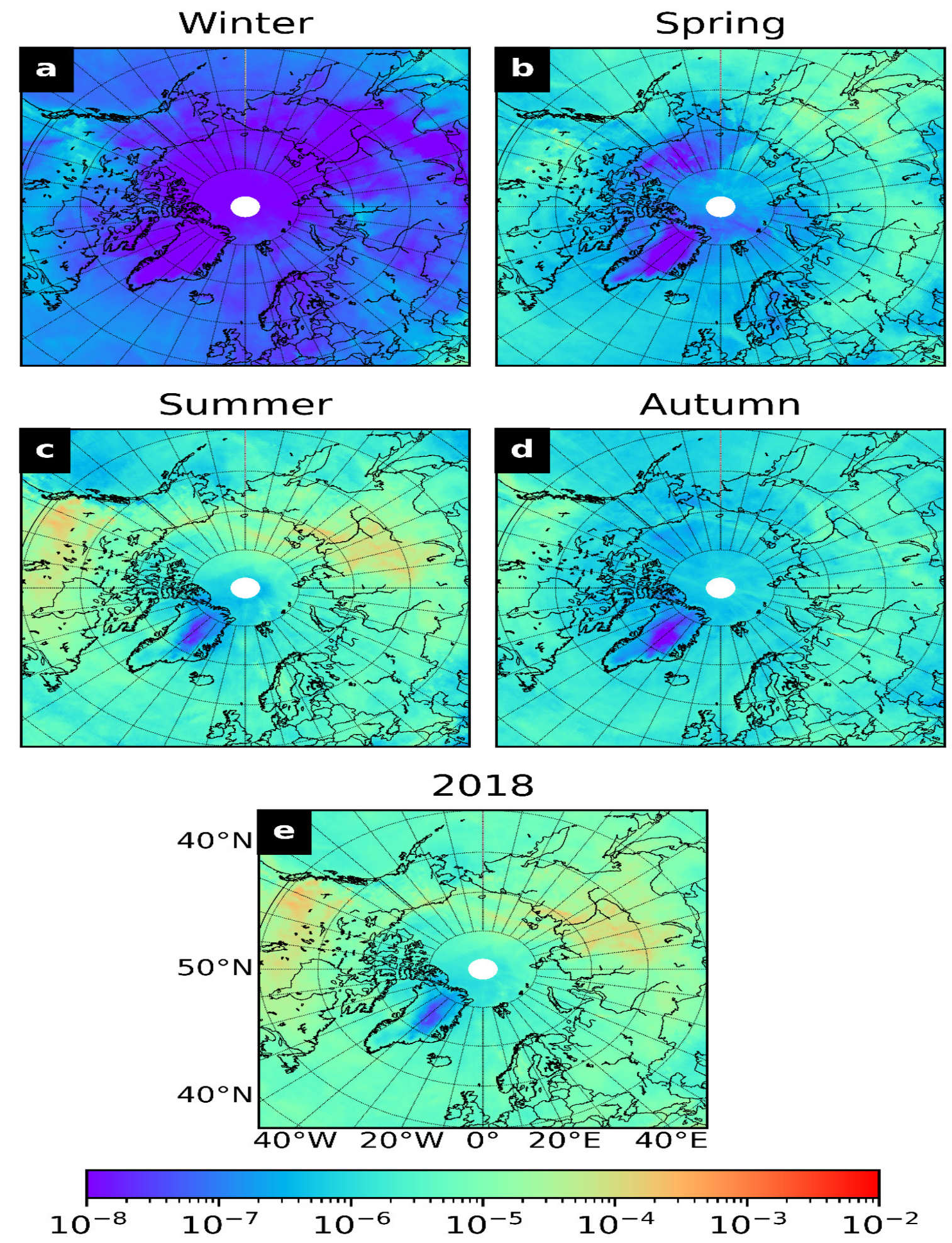

Figure 6.7. Seasonal (panels a-d) and annual (panel e) accumulation of BC deposition from all wildfires across the world in 2018. The deposition density is given in units of $\mathrm{kg} / \mathrm{m}^{2}$. 

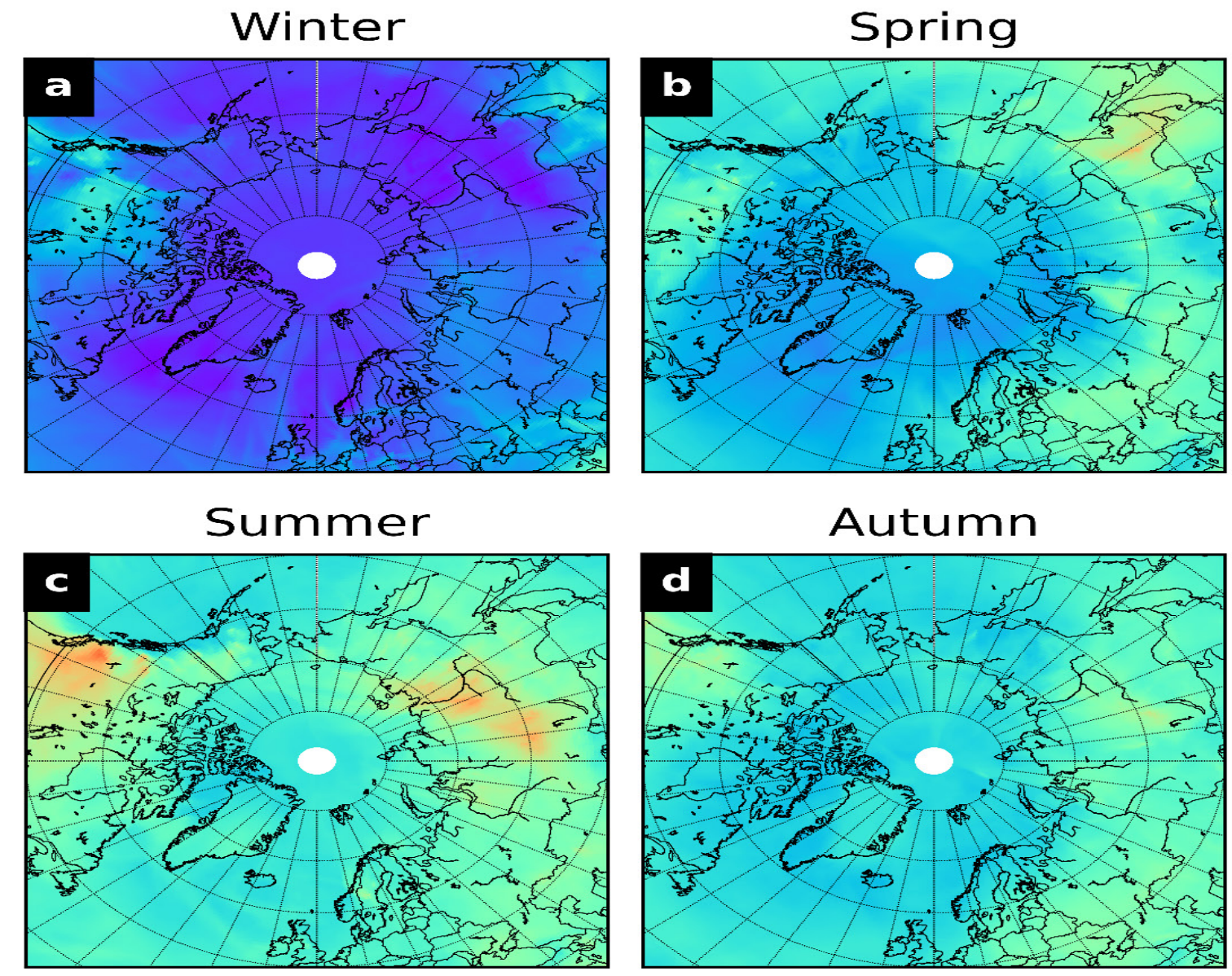

2018

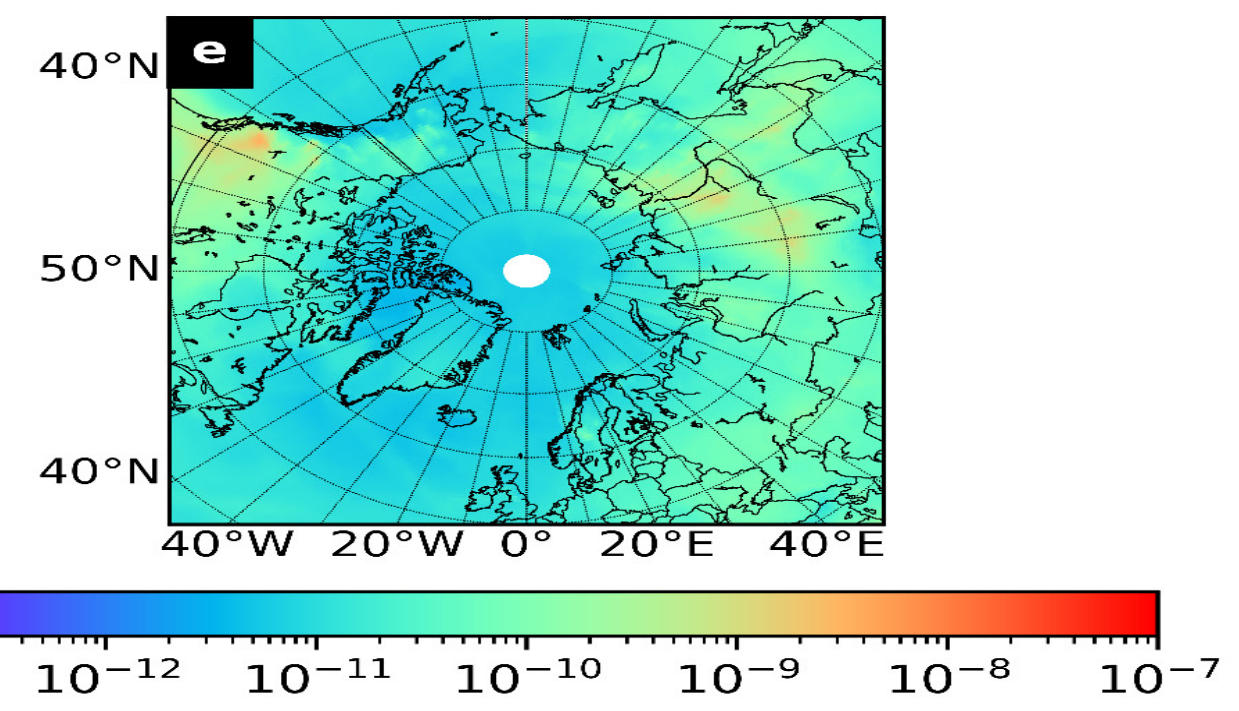

Figure 6.8. Seasonal (panels a-d) and annual (panel e) averages of BC concentrations in units of $\mathrm{kg} / \mathrm{m}^{3}$ from all wildfires across the world in 2018 .

There will always be wildfires that are not observed by remote sensing satellite instruments. One reason is that infrared sensors cannot observe fires through clouds, and a big part of the globe is constantly covered by clouds. A cloud property analysis (King et al., 2013) based on over 12 years' worth of MODIS observation data from Terra and over nine years of Aqua 
showed that, on average, the cloud cover over the earth's surface is $67 \%$. Wildfires exist only in land areas over which the cloud cover is $55 \%$ on average. Also, very small fires remain undetected due to the technical limitations of sensors. For example, under excellent observing conditions near nadir (i.e. the closest point to surface), MODIS is limited to detecting flaming fires bigger than about $100 \mathrm{~m}^{2}$ (Giglio et al., 2018). A third reason is that some fires occur within the time interval between two subsequent observations and hence will never get observed. This is mainly a problem with orbital satellite instruments which overpass a location on the earth's surface only a few times a day. Because of this reason, in areas where short-term wildfires exist, like for instance grassland fires on African savannas, MODIS misses most of the fires even on completely cloudless days. Unlike orbital instruments, geostationary ones, owing to a high temporal resolution, are able to detect not only all observable fires but also capture their evolution over time. The downside of geostationary instruments is that they must be positioned far away at an altitude of around 36000 kilometres above the equator and cannot therefore have as high a spatial resolution as orbital satellites. They also have a fixed location with respect to the earth's surface with a limited global coverage of about $43 \%$. However, a group of three geostationary satellites could cover nearly the entire globe, excluding the surroundings of the poles where wildfires do not occur naturally anyway.

It should be stressed that there is a great deal of uncertainty in the estimated emission values. The uncertainty is related to the missing FRP data and uncertainties in the emission coefficients. It is shown in (Wooster et al., 2005) that FRP is directly proportional to the biomass burning rate and can thus readily be converted to emissions by multiplying it by a land-use type-specific emission coefficient. The conversion of FRP to emissions requires knowledge of the time evolution of FRP of a fire. However, since IS4FIRES exploits MODIS FRP data, only one or a few arbitrary values of the time evolution are available. Therefore, the time evolutions of FRPs are estimated based on the few known FRP values provided by MODIS. Nevertheless, the IS4FIRES calibration compensates these issues to some extent. As an improvement for the future, more realistic estimates of emission quantities could be obtained by exploiting hightemporal geostationary satellite observations, which can provide the actual time-dependence of FRP of a fire. This would, however, be done at the expense of some loss in both the spatial resolution and satellite coverage.

Lastly, the results for $\mathrm{BC}$ arising from human activities are shown. The estimated wildfire emissions of $\mathrm{BC}$ are compared here to global anthropogenic emissions of $\mathrm{BC}$ using CAMS global anthropogenic emissions data for EC (CAMS_GLOB_ANT v2.1 with a spatial resolution of $0.5^{\circ} \times 0.5^{\circ}$, ca. $50 \mathrm{~km} \times 50 \mathrm{~km}$ at the equator). Figure 6.9 shows the global anthropogenic BC deposition density and ground-level concentrations in the northern hemisphere for 2018. The anthropogenic emissions are rather steadily produced and omnipresent in the atmosphere throughout the year. The seasonal averages are virtually indistinguishable from each other, all resembling Figure 6.9. The highest $\mathrm{BC}$ emissions are seen all the time in the areas of India and Southeast Asia. Figure 6.9a is illustrated on the same colour bar scale as used in Figures 6.4 and 6.7, so that the figures are directly comparable to each other. Similarly, Figures $6.9 \mathrm{~b}, 6.6$, and 6.8 , which illustrate concentrations, are comparable. As can be seen by a comparison of Figures $6.4 \mathrm{e}$ to $6.9 \mathrm{a}$ and $6.6 \mathrm{e}$ to $6.9 \mathrm{~b}$, respectively, the highest annual total BC deposition densities and ground-level concentrations of the Fennoscandian fires are in both cases roughly an order of magnitude smaller than the corresponding anthropogenic ones. 

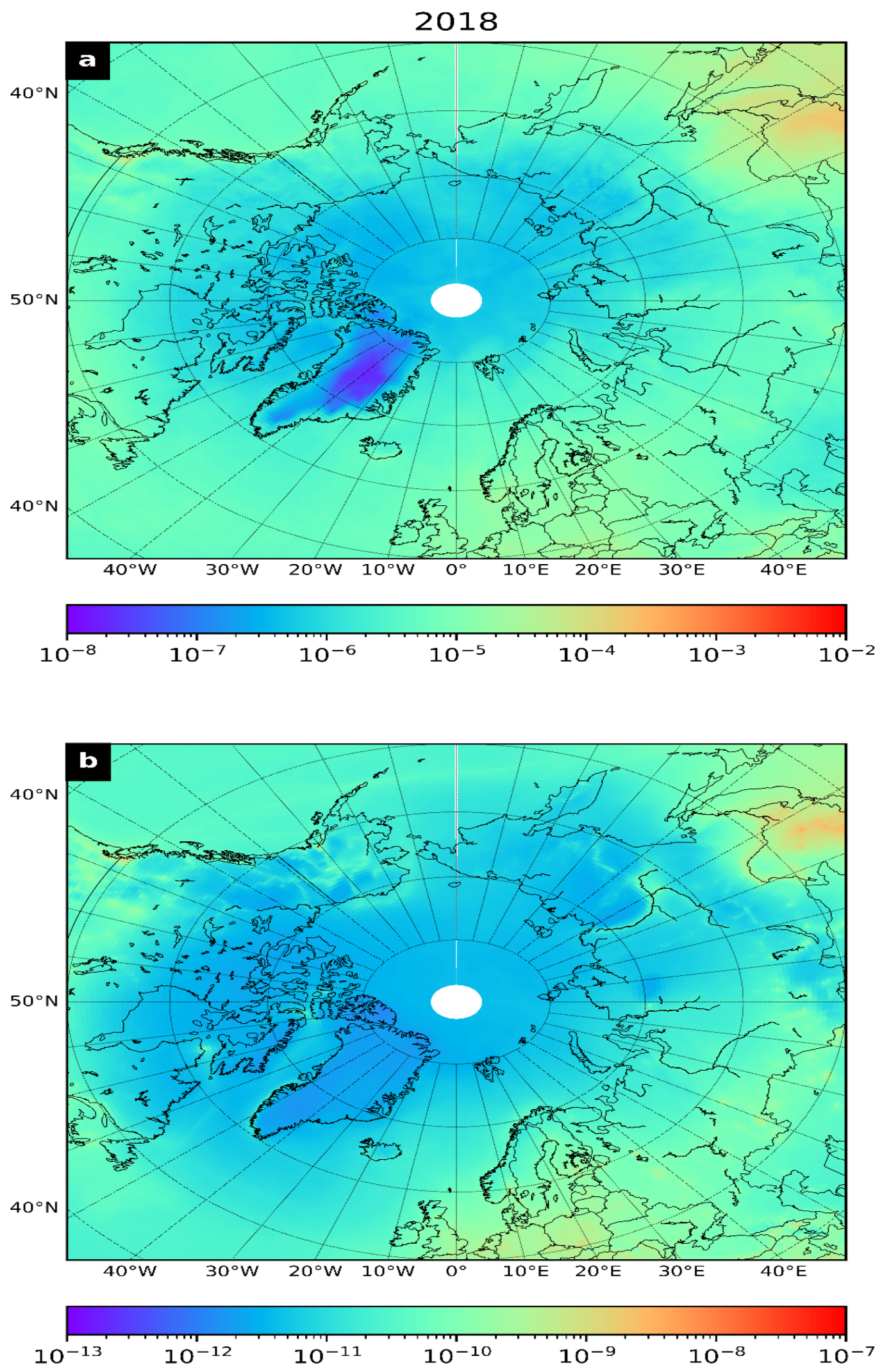

Figure 6.9. Panels (a) and (b) illustrate, respectively, the deposition $\left(\mathrm{kg} / \mathrm{m}^{2}\right)$ and concentration $\left(\mathrm{kg} / \mathrm{m}^{3}\right)$ of the annual global anthropogenic BC emission for the northern hemisphere in 2018. 
The main conclusions of this chapter can be summarised as:

- In 2018, the strongest BC emissions from Fennoscandian wildfires are concentrated in central Sweden and Norway and the Kola Peninsula. Their effects on Fennoscandia itself are minor and local compared to the effects of global BC emissions from wildfires or anthropogenic sources on Fennoscandia. Naturally, the locations of wildfires in Fennoscandia vary from year to year. Apart from the locations, there is no reason to assume that the effects would somehow be substantially different within Fennoscandia or outside it in any other year, at least in the near past or future.

- Neither Greenland nor the polar glacier is affected by BC deposition from Fennoscandian wildfires. Also, the global impact of both anthropogenic and wildfire $\mathrm{BC}$ depositions on Greenland are practically non-existent. Greenland is the least exposed place in terms of total global BC depositions in the Arctic Circle. In the case of the polar glacier, its $\mathrm{BC}$ deposition is due to global wildfires. The anthropogenic contribution to it is only minor. As for the concentrations of $\mathrm{BC}$, emissions from wildfires in Fennoscandia slightly increase the concentrations in the air. The BC concentrations spread to the environment and populated areas, mostly in the Fennoscandian region, south-eastern and eastern Europe and Russia. These effects are only felt in the summer and are small compared to the effects of global wildfires.

- In Fennoscandia, the highest concentrations of BC from Fennoscandian wildfires and concentrations of $\mathrm{BC}$ from anthropogenic sources are of the same order of magnitude, roughly $0.01-0.1 \mu \mathrm{g} / \mathrm{m}^{3}$, except in the most southern parts of Fennoscandia where the anthropogenic $\mathrm{BC}$ concentrations are of the same order of magnitude as those arising from global wildfires, roughly $0.1-1 \mu \mathrm{g} / \mathrm{m}^{3}$. Both global wildfire and anthropogenic concentrations of $\mathrm{BC}$ are constantly present in the region of Fennoscandia throughout the year, unlike the contribution from Fennoscandian wildfires, which is mostly in the summer.

- All in all, the effects of BC from wildfires in Fennoscandia on the environment and air quality are relatively small compared to the total ambient BC.

\section{References}

Adams, K., Greenbaum, D.S., Shaikh, R., van Erp, A.M., Russell, A.G. 2015. Particulate matter components, sources, and health: Systematic approaches to testing effects. Journal of the Air \& Waste Management Association 65: 544-558.

Akagi, S.K., Yokelson, R.J., Wiedinmyer, C., Alvarado, M.J., Reid, J.S., Karl, T., Crounse, J. D., Wennberg, P.O. 2011. Emission factors for open and domestic biomass burning for use in atmospheric models. Atmospheric Chemistry and Physics 11: 4039-4072.

Andreae, M.O., Gelencsér, A. 2006. Black carbon or brown carbon? The nature of lightabsorbing carbonaceous aerosols. Atmospheric Chemistry and Physics 6: 3131-3148.

Bond, T.C., Doherty, S.J., Fahey, D.W., Forster, P.M., Berntsen, T., DeAngelo, B.J., Flanner, M.G., Ghan, S., Kärcher, B., Koch, D., Kinne, S., 2013. Bounding the role of black carbon in the climate system: A scientific assessment, Journal of geophysical research: Atmospheres 118: 5380-5552.

Buseck, P.R., Adachi, K., Gelencsér, A., Tompa, É., Pósfai, M. 2012. Are black carbon and soot the same? Atmospheric Chemistry and Physics Discussion 12: 24821-24846. 
Cook, J., Oreskes, N., Doran, P.T., Anderegg, W.R., Verheggen, B., Maibach, E.W., Carlton, J.S., Lewandowsky, S., Skuce, A.G., Green, S.A., Nuccitelli, D. 2016. Consensus on consensus: a synthesis of consensus estimates on human-caused global warming. Environmental Research Letters 11: 048002.

Giglio, L., Schroeder, W., Hall, J.V., Justice, C.O. 2018. MODIS Collection 6 Active Fire $\begin{array}{llll}\text { Product User's Guide Revision } & \text { B. } & \text { http:/modis- }\end{array}$ fire.umd.edu/files/MODIS_C6_Fire_User_Guide_B.pdf.

Hamanaka, R.B., Mutlu, G.M. 2018. Particulate Matter Air Pollution: Effects on the Cardiovascular System. Frontiers in endocrinology 9: 680.

IPCC, 2014: Climate Change 2014: Synthesis Report. Contribution of Working Groups I, II and III to the Fifth Assessment Report of the Intergovernmental Panel on Climate Change [Core Writing Team, R.K. Pachauri, L.A. Meyer (eds.)]. IPCC, Geneva, Switzerland, 151 pp.

Jacobson, M. 2001. Strong radiative heating due to the mixing state of black carbon in atmospheric aerosols. Nature 409: 695-697.

Johnson, A.L., Abramson, M.J., Dennekamp, M., Williamson, G.J., Guo, Y. 2020. Particulate matter modelling techniques for epidemiological studies of open biomass fire smoke exposure: a review. Air Quality, Atmosphere \& Health 13: 35-75.

Johnston, F.H., Henderson, S.B., Chen, Y., Randerson, J.T., Marlier, M., DeFries, R.S., Kinney, P., Bowman, D.M., Brauer, M., 2012. Estimated global mortality attributable to smoke from landscape fires. Environmental Health Perspectives 120: 695-701.

King, M.D., Platnick, S., Menzel, W.P., Ackerman, S.A., Hubanks, P.A. 2013. Spatial and Temporal Distribution of Clouds Observed by MODIS Onboard the Terra and Aqua Satellites. IEEE Transactions on Geoscience and Remote Sensing 51: 3826-3852.

Knorr, W., Jiang, L., Arneth, A. 2016. Climate, CO2 and human population impacts on global wildfire emissions. Biogeosciences 13: 267-282.

Kollanus, V., Prank, M., Gens, A., Soares, J., Vira, J., Kukkonen, J., Sofiev, M., Salonen, R.O., Lanki, T. 2016. Mortality due to Vegetation Fire-Originated PM2.5 Exposure in Europe Assessment for the Years 2005 and 2008. Environmental health perspectives 125: 30-37.

Lelieveld, J., Evans, J.S., Fnais, M., Giannadaki, D., Pozzer, A. 2015. T The contribution of outdoor air pollution sources to premature mortality on a global scale. Nature 525: 367-371.

Lim, Y.H., Kim, H., Kim, J.H., Bae, S., Park, H.Y., Hong, Y.C. 2012. Air pollution and symptoms of depression in elderly adults. Environmental health perspectives 120: 10231028.

Lobert, J.M., Keene, W.C., Logan, J.A., Yevich, R. 1999. Global chlorine emissions from biomass burning: Reactive Chlorine Emissions Inventory. Journal of Geophysical Research: Atmospheres 104: 8373-8389.

Lozano, O. M., Salis, M., Ager, A. A., Arca, B., Alcasena, F. J., Monteiro, A. T., Finney, M. A., Del Giudice, L., Scoccimarro, E., Spano, D. 2017. Assessing Climate Change Impacts on Wildfire Exposure in Mediterranean Areas. Risk Analysis 37: 1898-1916.

Marlon, J.R., Bartlein, P.J., Carcaillet, C., Gavin, D.G., Harrison, S.P., Higuera, P.E., Joos, F., Power, M.J., Prentice, I.C., 2008. Climate and human influences on global biomass burning over the past two millennia. Nature Geoscience 1: 697-702.

Pechony, O., D. T. Shindell. 2010. Driving forces of global wildfires over the past millennium and the forthcoming century. Proceedings of the National Academy of Sciences of the United States of America 107: 167-170.

Perovich, D., Meier, W., Tschudi, M., Farrell, S., Hendricks, S., Gerland, S., Kaleschke, L., Ricker, R., Tian-Kunze, X., Webster, M. 2019. Wood, K. Sea ice. Arctic Report Card 2019, Richter-Menge, J., Druckenmiller, M.L., Jeffries, M., Eds., https://www.arctic.noaa.gov/Report-Card. 
Pope, C.A. III, Dockery, D.W. 2006. Health Effects of Fine Particulate Air Pollution: Lines that Connect. Journal of the Air \& Waste Management Association 56: 709-742.

Samek, L. 2016. Overall human mortality and morbidity due to exposure to air pollution. International journal of occupational medicine and environmental health 29: 417-426.

Sims, R., Gorsevski, V., Anenberg, S. 2015. Black Carbon Mitigation and the Role of the Global Environment Facility: A STAP Advisory Document. Global Environment Facility, Washington, D.C.

Streets, D.G., Bond, T.C., Lee, T., Jang, C. 2004. On the future of carbonaceous aerosol emissions. Journal of Geophysical Research 109: D24212.

Szyszkowicz, M., Willey, J.B., Grafstein, E., Rowe, B.H., Colman, I. 2010. Air pollution and emergency department visits for suicide attempts in vancouver, Canada. Environmental health insights 4: 79-86.

Thurston, G.D., Ahn, J., Cromar, K.R., Shao, Y., Reynolds, H.R., Jerrett, M., Lim, C.C., Shanley, R., Park, Y., Hayes, R.B. 2016. Ambient Particulate Matter Air Pollution Exposure and Mortality in the NIH-AARP Diet and Health Cohort. Environmental health perspectives 124: 484-490.

Veira, A., Lasslop, G., Kloster, S. 2016. Wildfires in a warmer climate: Emission fluxes, emission heights, and black carbon concentrations in 2090-2099. Journal of Geophysical Research: Atmosphere 121: 3195-3223.

WHO, 2013. Regional Office for Europe. Review of evidence on health aspects of air pollution - REVIHAAP Project: Technical Report [Internet]. Copenhagen: WHO Regional Office for Europe; 2013. Available from:_https://www.ncbi.nlm.nih.gov/books/NBK361805/.

WHO, 2018. 9 out of 10 People Worldwide Breathe Polluted Air, But more Countries are Taking Action, News release. https://www.who.int/news-room/detail/02-05-2018-9-out-of10-people-worldwide-breathe-polluted-air-but-more-countries-are-taking-action.

Wooster, M.J., Roberts, G., Perry, G.L.W., Kaufman, Y.J. 2005. Retrieval of biomass combustion rates and totals from fire radiative power observations: Frp derivation and calibration relationshipsbetween biomass consumption and fire radiative energy release. Journal of Geophysical Research: Atmospheres 110: D24. 


\title{
7. International cooperation on the forest fire prevention
}

\author{
Rami Ruuska, Jan Wahlberg
}

Wildfires and forest fires have been hot topics in recent years, both in Finland and globally. Our neighbouring countries Sweden and Russia have experienced a number of severe wildfires, and wildfires in the US, Australia and Southern Europe have even escalated into disasters.

Strengthening cooperation on climate change mitigation and forest fire suppression is necessary in the Arctic, Barents and Nordic Baltic regions as the increase in average temperatures is three times as high in the Arctic compared to the global averages. We need to work for a broad cooperation to cut black carbon emissions in the region and globally. The role of the Arctic Council, Barents Euro-Arctic Council and NEFCO (the Nordic Environment Finance Corporation) are essential in this regard.

Finland will be chairing the Barents Euro-Arctic Council in 2021-2023. During its presidency Finland will focus on sustainable development and a healthy environment, people-to-people contact and transport and logistics.

Rescue cooperation has been one of the success stories in the Barents region. It will also be highlighted during the Finnish Presidency in 2022 with the next Barents Rescue exercise. This cooperation makes a valuable contribution to the security, efficiency and friendly relations between the people and authorities in the Barents region. Due to climate change and increasingly extreme weather conditions, cooperation in detecting and extinguishing forest fires will be one of the key priorities.

Finland also chairs this year's (2021) Nordic Baltic cooperation. The Nordic Baltic Foreign Ministers' meeting in September 2021 could be an opportunity to bring this discussion to a political level.

This means that we should invest in the research and development of a system that helps to prevent wildfires and forest fires. We need to study the prevention of fires, the early identification of fires, the rapid alerting of rescue services, and firefighting and rescue operations to deploy even better methods. These topics have certainly been studied fairly extensively over the years, but there is often room for improvement in the implementation of research results and any development proposals.

Currently, international research and development often includes the development of equipment and methods. For example, the use of drones or, say, forest machines in firefighting operations is an interesting new area of research. Technological development and the use of artificial intelligence (AI) in forecasting the spread of wildfires and in identifying forest fuels, for example, are already cross-boundary research topics.

Finnish rescue services have identified how important rescue management and the management of the continuity of related firefighting operations have become. Fighting forest fires is a typical example of a large rescue operation, but it is still rarely expected that it will take days or even weeks. Large and numerous simultaneous fires of up to dozens or hundreds call for accurate coordination and management, both regionally and nationally, sometimes even internationally. 
Monitoring and command centre operations and their development are an integral part of these activities.

International cooperation has a long history in wildfire operations. For years, various working groups and networks have considered how to improve operations internationally. For example, the EU Expert Group on Forest Fires (EGFF) has convened two or three times a year for at least 20 years. In addition, the Global Fire Monitoring Centre (GFMC) has worked extensively in networks for several decades.

Bilateral agreements and assistance given to neighbouring countries have been stable and typical practices in the prevention of forest fires. If a country faces a difficult forest fire, it is only natural to first ask for more help and resources from a neighbour. In the name of solidarity, assistance will also be given if this is possible given each country's situation. Here again, the role of the Arctic Council, Barents Euro-Arctic Council and Nordic Baltic cooperation is crucial.

Providing help in aerial firefighting is a basic method and probably the most common way to offer international assistance in fighting forest fires. While many countries have firefighting airplanes and helicopters, not many have enough aircraft to cover the peaks potentially required during difficult fire seasons. Aerial firefighting resources may be sought and accepted at a relatively low threshold. Indeed, aerial firefighting resources have been discussed frequently in international forums in recent years. The EU has also tried to answer this question by establishing new rescEU forces.

However, it should be noted that wildfires and forest fires are still fought primarily on the ground, at least in Finland. Wildfire fighting calls for such a significant number of resources that it must be possible to send ground forces to neighbouring countries and to accept them.

Here, we come to one of the most important questions that concerns the entire international forest fire community: is the Host Nation Support (HNS) system in such a condition that international assistance can truly be asked for and received? Like the EU Civil Protection Mechanism and the training it provides, the standard operating procedures (SOP) defined for aerial firefighting are a good start, but there is still much to do in coordinating all the available methods.

International debate always returns to how much all this costs and who pays. As forest fire fighting is always expensive, the payer should be defined beforehand.

Many countries are wrestling with the same problems and the same themes. Finland has also addressed the issue in recent years, as we have realised that the forest fire risk is also a reality in the Nordic countries. The wildfire and forest fire prevention system needs to be developed. New research activities and the implementation of research and development proposals are concrete examples of new measures.

Forest fires are a significant contributor of greenhouse gases in the atmosphere. Climate change is making extreme wildfires more common and damaging. The fight against forest fires must be made a central part of our common climate change agenda - locally, nationally, regionally and globally. It is only by reducing the social, economic and ecological costs of forest fires that we can meet the objectives under the Sustainable Development Goals and the Paris Agreement. 


\section{Acknowledgements}

We would like to thank all who have participated to the steering committee work for their constructive feedback during the project: Anita Koivuselkä (Ministry for Foreign Affairs of Finland), Tuija Maanoja (Ministry of Transport and Communications), Jussi Kaurola and Tuomo Bergman (Finnish Meteorological Institute), Antti Asikainen (Natural Resources Institute Finland), Rami Ruuska, Jari Honkanen and Esa Kokki (Ministry of the Interior), Sanna Paanukoski and Tatu Torniainen (Ministry of Agriculture and Forestry of Finland) and Kaarle Kupiainen (Ministry of Environment).

We thank Juha Virto, Chief Executive Officer of Rescue Services of Southwest Finland for providing information about Pyhäranta forest fire 2018 rescue operation, and Jouko Anttila and Esa Urhonen for providing photos from the field.

We are thankful for Johannes Ketola (Senior Officer for Rescue Services, Regional State Administrative Agency for Eastern Finland) for helping us to retrieve information from the PRONTO database. Senior specialist Joel Kauppinen (Ministry of the Interior) prepared the map of fire stations in Finland 2021.

Tero Partanen wish to acknowledge Drs. Andreas Uppstu and Yuliia Palamarchuk for helping with the simulation preparation, Prof. Mikhail Sofiev whose project plan contribution was utilised at the beginning of Section 6.3, Doc. Ari Karppinen for reading through the chapter and suggesting editorial improvements, and Prof. Juha Aalto for commenting and suggesting improvements on the chapter.

Finally, we acknowledge the project funding by the Ministry for Foreign Affairs of Finland. 
FINNISH METEOROLOGICAL INSTITUTE

Erik Palménin aukio 1

P.O. Box 503

FI-00560 HELSINKI

tel. +358295391000

\section{WWW.FMI.FI}

FINNISH METEOROLOGICAL INSTITUTE REPORTS 2021:3

ISSN 0782-6079

ISBN 978-952-336-134-8 (paperback)

ISBN 978-952-336-135-5 (pdf)

https://doi.org/10.35614/isbn.9789523361355
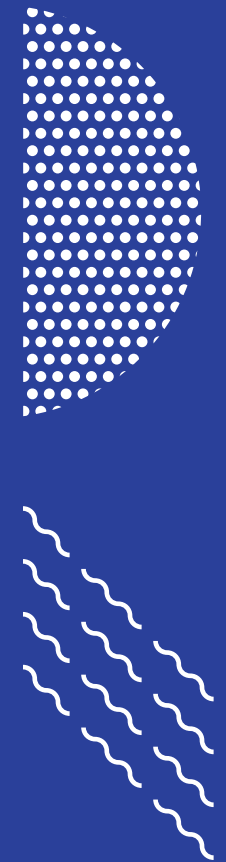

:०००

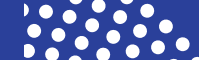

